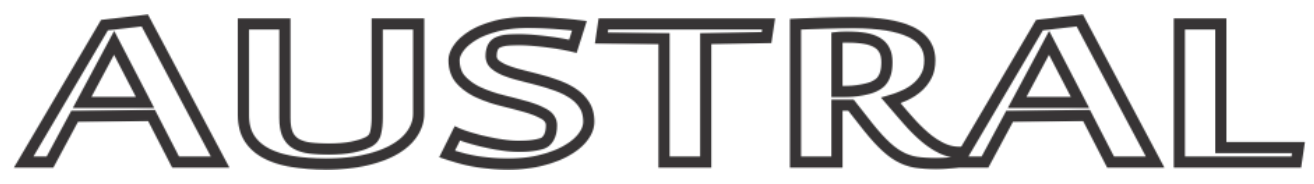

Brazilian Journal of Strategy \& International Relations

Revista Brasileira de Estratégia e Relações Internacionais

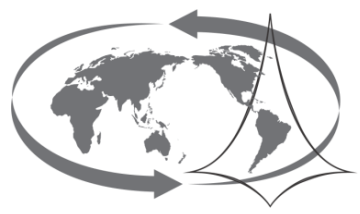

Africa: different views on its strategic importance

Porto Alegre, v.3, n.5 | Jan/Jun. 2014
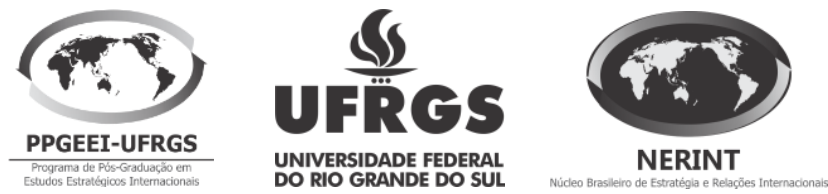


\section{ABOUT THE JOURNAL}

AUSTRAL: Brazilian Journal of Strategy \& International Relations is an essentially academic vehicle, linked to the International Strategic Studies Doctoral Program (PPGEEI) of the Faculty of Economics (FCE) of the Universidade Federal do Rio Grande do Sul (UFRGS) and to the Brazilian Centre for International Relations and Strategic Studies (NERINT) - a research center of the Latin American Institute for Advanced Studies (ILEA/UFRGS). Its pluralist focus aims to contribute to the debate on the international political and economic order from the perspective of the developing countries.

The journal publishes original articles and book reviews in English, Portuguese or Spanish about themes that lie in the vast area of Strategy and International Relations, with special interest in issues related to developing countries and the SouthSouth relations, their security issues, the economic, political and diplomatic development of emerging nations and their relations with the traditional powers. The journal's target audience consists of researchers, specialists and postgraduate students of International Relations.

The journal will try, through its publication policy, to ensure that each volume has at least one author from each of the great southern continents (Asia, Latin America, Africa), in order to stimulate the debate and the diffusion of the knowledge produced in these regions. All of the contributions will be subjected to a scientific review.

This work was supported by the Advisory Board for Cooperation and International Relations of the Governor of Rio Grande do Sul's Office, and by the Journal Edition Supportive Program (PAEP) - UFRGS.
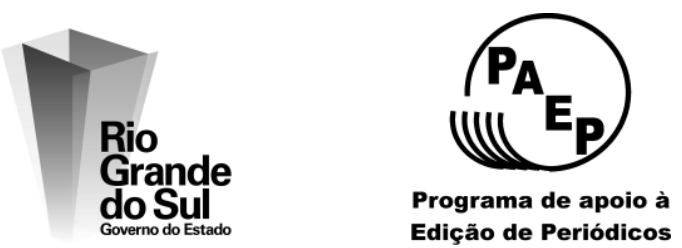


\section{Editorial Team Equipe Editorial}

Editor Editor-Chefe

Paulo Visentini (Universidade Federal do Rio Grande do Sul, Brazil)

Deputy Editor Editor Adjunto

Marco Cepik (Universidade Federal do Rio Grande do Sul, Brazil)

\section{Editorial Board Comitê Editorial}

Adam Habib (University of Johannesburg, South Africa)

André Luiz Reis da Silva (Universidade Federal do Rio Grande do Sul, Brazil)

Érico Esteves Duarte (Universidade Federal do Rio Grande do Sul, Brazil)

Fábio Morosini (Universidade Federal do Rio Grande do Sul, Brazil)

Gladys Lechini (Universidad Nacional de Rosario, Argentina)

Immanuel Wallerstein (Yale University, United States of America)

Marcelo Milan (Universidade Federal do Rio Grande do Sul, Brazil)

Ruchita Beri (Institute for Defence Studies an Analyses, India)

Edition Assistant Assistente de Edição

Pedro Alt (Universidade Federal do Rio Grande do Sul, Brazil)

\section{Editorial Committee Conselho Editorial}

Amado Luiz Cervo (Universidade de Brasília, Brazil)

Analúcia Danilevicz Pereira (Universidade Federal do Rio Grande do Sul, Brazil)

André Moreira Cunha (Universidade Federal do Rio Grande do Sul, Brazil)

Antônio Carlos Lessa (Universidade de Brasília, Brazil)

Antonio Jorge Ramalho (Universidade de Brasília, Brazil)

Bertrand Badie (Sciences Po, France)

Boris F. Martynov (Russian Academy of Sciences, Russia)

Carlos Arturi (Universidade Federal do Rio Grande do Sul, Brazil)

Carlos Aurélio Pimenta de Faria (Pontifícia Universidade Católica de Minas Gerais, Brazil)

Chris Landsberg (University of Johannesburg, South Africa)

Hüseyin Bağci (Middle East Technical University, Turkey)

Ilter Turan (Istanbul Bilgi University, Turkey)

José Ariosa Pérez (Universidad de la Habana, Cuba)

Liu Youfa (China Institute of International Studies, China)

Lotfi Kaabi (Institut Tunisien des Études Stratégiques, Tunisia)

Mamoudou Gazibo (Université de Montréal, Canada)

Marcos Costa Lima (Universidade Federal de Pernambuco, Brazil)

Maria Regina Soares de Lima (IESP, Universidade do Estado do Rio de Janeiro, Brazil)

Mehdi Parvizi Amineh (University of Amsterdam, Netherlands)

Melissa H. Conley Tyler (Australian Institute of International Affairs, Australia)

Monica Hirst (Universidad Torcuato di Tella, Argentina)

Nikolai Mikhailov (Russkiy Mir Foundation, Russia)

Sean W. Burges (Australian National Centre for Latin American Studies, Australia) 


\section{AUSTRAL}

(C) Programa de Pós-Graduação em Estudos Estratégicos Internacionais - UFRGS

Cover: Pedro Felipe da Silva Alt

AUSTRAL: Brazilian Journal of Strategy \& International Relations is available online in English and Portuguese at: http://seer.ufrgs.br/austral/.

\section{Contact}

Universidade Federal do Rio Grande do Sul - Faculdade de Ciências Econômicas Programa de Pós-Graduação em Estudos Estratégicos Internacionais Av. João Pessoa, 52 sala 33-A - $3^{\circ}$ andar - CEP 90040-000 - Centro - Porto Alegre/RS - Brazil

Phone: +55 513308.3963 Fax: +55 513308.3963 Email: austral@ufrgs.br

\section{Cataloging-in-Publication (CIP)}

Austral : Revista Brasileira de Estratégia e Relações

Internacionais $=$ Brazilian Journal of Strategy \&

International Relations / Universidade Federal do Rio

Grande do Sul, Faculdade de Ciências Econômicas,

Programa de Pós-Graduação em Estudos Estratégicos

Internacionais. - v. 2, n. 3 (Jan./Jun. 2013). - Porto Alegre:

PPGEEI/FCE/NERINT/ UFRGS, 2012-

Semestral.

ISSN 2238-6262. e-ISSN 2238-6912

1. Political Science. 2. International Relations. 3.

International Politics. 4. Diplomacy. 5. Developing Countries.

CDU 327

Biblioteca Gládis Wiebbelling do Amaral, Faculdade de Ciências Econômicas da UFRGS. 


\section{AUSTRALA}

\section{Volume 3, Number 5 (Jan/Jun. 2014)}

Editor's Note:

Paulo Fagundes Visentini

Structural Power toward Weak States: France, not China, matters in

Francophone Africa.

Olivier Mbabia

Africa and the Emerging Powers: the South and the Unholy Cooperation....

Paulo Fagundes Visentini

The Role of Commercially Provided Security in Africa's Patrimonial Security

Complex.....

Christopher Kinsey, Andreas Krieg

Asymmetric Warfare: Experiences, Perspectives, Inkling and Challenges with a Focus on Zimbabwe.

Raymond Mhaparara, Lucky Bassie Bangidza, Steven Gwekwerere

Towards Redefining the News Agenda in the Nigerian Media for National Development.

Osakue Stevenson Omoera

National Army and State-Building in Africa: the Brazilian approach in the case of the Democratic Republic of Congo....

Igor Castellano da Silva, José Miguel Quedi Martins

The Foreign Policy of the New South Africa: re-insertion and regional affirmation.

Kamilla Raquel Rizzi, Nathaly Xavier Schütz

Cooperation and Conflict: the Dynamics of Oil and Natural Gas in Central Asia...

Paulo Duarte

The Political Role of the United States in the Argentinean Default. 225

Roberto Miranda

New Independent Foreign Policy, a Matter of Emphasis....

Eduardo Brigidi de Mello

Partners.

Submission Standards/Previous Numbers. 



\section{EDITOR'S NOTE}

\section{Paulo Fagundes Visentini ${ }^{1}$}

In a short period, the African continent became, from a situation of lesser relevance for the analysts, a region of higher strategic value. The complex academic understanding of this evolution is made difficult, in Brazil, for unfamiliarity towards the region and, in Europe, for the prejudiced vision. But, as a Brazilian diplomat stationed in the old continent once argued, "ignorance is more easily overcome than prejudice". Thus, as a contribution to the debate, AUSTRAL dedicates this issue to the international relations of Africa.

The dynamic axis of the world system had already been gradually moving from North to South, from the center to the semi-periphery, a process that radiates shock waves to the periphery. With the Euro-American economic and financial crisis, started in 2008-2009, and the consequent deepening of diplomatic and military tensions worldwide, part of the traditional powers reacted against this evolutionary redistribution of spheres of power. Russia and China, however, have shown steadiness, while the Middle East and Latin America, with different intensities, are diving into a situation of uncertainty.

Africa, in turn, given its geopolitical position and its new vectors of international insertion, has become an extremely relevant locus for the repositioning of forces in global scale. It has been a space of hitherto low strategic density, where the use of limited resources can have an extended effect. In this continent, the economic pressures and the Color Revolutions (Regime Change) are less efficient, and the power projection by the North

1 International Relations Professor at Universidade Federal do Rio Grande do Sul. Director of CEBRAFRICA: Brazilian Centre for African Studies. CNPq Researcher. Rio Branco Chair for International Relations at Oxford, 2014. E-mail: paulovi@ufrgs.br. 
occurs in a traditional way: militarization, conflicts (with an old form but new content) and economic competition against the emerging powers for natural resources and investment zones.

This is because the BRICS, for two decades, have been increasingly present in the continent, accelerating the African development and reconfiguring the national and international power of the continent's nations. Even the United States, which had shown little interest towards Africa until then, became present and active, in an expedited manner. The fight against "terrorism" in the Sahara, the establishment of AFRICOM (Africa Command), the reestablishment of the Fourth Fleet in the South Atlantic Ocean and the increasing military, economic and political presence are some of the examples of this process.

The growing presence of China, India and Brazil in the African continent is also followed by that of Russia, Turkey, Iran and the countries of the Gulf Cooperation Council, in addition to Cuba's permanent presence. Such phenomenon occurred in parallel (and in an interactive way) with the affirmation of the new South Africa, Angola, Nigeria and Libya, and the launching of the New Partnership for Africa's Development (NEPAD) and the transformation of the Organization of African Unity (OAU) into the African Union (AU), both in 2002. Such events contributed to Africa's economic, social and political advances, as well as for a larger autonomy and diplomatic protagonism of the continent's nations.

The association of Africans with the emerging powers in international organizations and their connection with the new economic flows generated a challenging perception in the Organization for Economic Cooperation and Development (OECD). This was associated with the geopolitical position of the continent, which embraces, equally, the maritime spaces of the South Atlantic and Indian Oceans. For the traditional powers to breach the forming southern axis, it is necessary to control or, at least, influence the states of Africa.

The Western control over Northeast Africa is important to keep a position of flank that allows for monitoring the Indian Ocean and the Middle East, from which the United States flows back. And the shift of the US axis of interest to the oil of Brazil (pre-salt) and the Gulf of Guinea (which offer security facilities and low shipping cost), on the other hand, makes South Atlantic an important sphere for Washington. The natural resources and 
political position of the South American and African nations make this ocean a space to which the North Atlantic Treaty Organization (NATO) seeks to project power.

NATO's intervention in Libya, the militarization of the Sahara on the pretext of "fighting terrorism", the renewed French interventions in several African nations and the growing US military presence across the continent (advisors, maneuvers, weapons supply) are indicators of the new dispute over Africa. How will the African nations and their emerging partners react? A new scenario is being drawn, with unpredictable consequences.

We thank the International Relations and Cooperation Office of the Governor of the State of Rio Grande do Sul for the support and the Office of the Vice Provost for Research of the Federal University of Rio Grande do Sul (for the translation), as well as the whole team who worked in editing and translating, particularly Edition Assistant Pedro Alt.

$$
* * *
$$

\section{NERINT, 15 YEARS}

In August 2014, the Brazilian Centre for Strategy and International Relations (NERINT) at the Latin American Institute for Advanced Studies (ILEA) of UFRGS, co-editor of AUSTRAL, celebrates the fifteenth anniversary of its foundation. Its independent academic activity has been crowned with success, for the publication of 36 books, conducting dozens of national and international seminars and, above all, because it constituted the basis for the creation of undergraduate and graduate programs in International Relations at UFRGS. It also housed the Brazilian Centre for African Studies (CEBRAFRICA, formerly CESUL), which celebrates in the same month its nine years of existence.

The cooperation with specialized centers and academics from all continents represents, likewise, a milestone of its achievements. Moreover, its anticipatory vision of the global system transformation demonstrated its success in seeking an alternative (and difficult) path of affirmation in the field 
of international studies. Few weeks before NERINT's fifteenth anniversary, the BRICS gathered in Fortaleza, Brazil, making important decisions, which converge with its research agenda.

Our deepest thanks to all research professors, graduate students and Scientific Initiation fellows who have collectively built this center, differentiated from the officialism and/or foreignism of some counterparts. In fifteen years of existence, NERINT has contributed to the diplomatic and academic renewal of Brazil and other developing nations. It has also sought to contribute to building a multipolar world of peace and economic and social development for all peoples. 


\section{STRUCTURAL POWER TOWARD WEAK STATES: FRANCE, NOT CHINA, MATTERS IN FRANCOPHONE AFRICA}

\section{Olivier Mbabia ${ }^{1}$}

The magnitude of assignment of the People's Republic of China in Africa has recently ignited a tide of 'speedy' literature ranking the latter as the main actor to the detriment of traditional ones. A close look at this issue, however, shows that this deduction seems all the less simplistic. By deliberately limiting the present analysis to the so-called Francophone Africa $^{2}$, where Chinese engagement is as considerable as elsewhere on the continent, it appears that this conclusion is shaky when submitted to a rigorous analysis. Can a causal relation be established between the progression of this presence and Beijing's actual influence? Can power or influence be subsumed to an ever-growing presence and an economic vitality? Are these parameters enough to unseat old colonial powers, especially France in its original and natural area of influence?

A positive answer does not help explaining how can the authority and legitimacy meted by French leaders and institutions on governing elite and the populations be accounted for more than half a century after the physical

1 Researcher at Université de Montréal, Canada. Postdoctoral student at the same institution. E-mail: oliviermbabia@yahoo.com.

2 The expression "Francophone Africa" generally refers to those countries that have French as an official or a spoken language. In this study, the term is used to designate the countries of Sub-Saharan Africa that maintain exceptionally - abnormally in some cases - close political, cultural, economic and military relations with France, their former colonial power, namely: Benin, Burkina Faso, Central African Republic, Chad, Comoros, Republic of Congo, Djibouti, Gabon, Guinea, Ivory Coast, Madagascar, Mali, Mauritania, Niger, Senegal. Other countries are Cameroon and Togo, two former German protectorates transferred to France following the Treaty of Versailles in 1919. 
dismantling of the colonial empire. Some recent events illustrate this point. In 2009, the French response to Andry Rajoelina - who found shelter in the French embassy - coup in Madagascar was to normalize the de facto situation. In December 2012, "French cousins" were called for help by the Central African President in a bid to stop the progress of rebels towards Bangui ${ }^{3}$. In February 2013, a few weeks after the launching of the Serval Operation, the French Head of State was triumphal welcome in Mali. Many more manifestations of this type are depicted through the attraction towards television channels, the passion fed by the military parade on July $14^{\text {th }}$, the festive enthusiasm expressed in French presidential elections (especially that of May 2012 with the ousting of Nicholas Sarkozy) in Brazzaville, Libreville, Abidjan, Dakar or Douala.

This article seeks to explain the determinants of France influence compared to that of China in Francophone Africa. Focusing on the paradigm of structural power as theorized by Susan Strange, it will attempt to debunk any considerations of a "declining" French influence in Francophone Africa. It will be argued that the existence of "special relationships" manifested through close political and cultural ties but also through covert economic and military networks give onto France the potentials to determine the structure of the regional political economy, in which Francophone African States evolve (hypothesis). The first section discusses the debate on the definition of power. The next section compares the determinants and modalities of Chinese and French involvement based on the structures of security, finance, production and knowledge. The third section explores how the current configuration enables France to outrun China sustainably. Particular attention will be given to the issues and challenges of the French power in its natural zone of influence. Finally, in the conclusion, I underline that Chinese engagement in this region is even more "shallow" as far as it is bereft of content and intensity.

${ }^{3}$ François Bozizé said: "We are asking our cousins the French and the United States, which are major powers, to help us push back the rebels to their initial positions in a way that will permit talks in Libreville to resolve this crisis." See Valdmanis and Osborn, 2012. 


\section{Power and Structural Power}

Power is a general concept and, hence, less operational and very much debated. It remains a central issue in international relations - especially for the realists. Taking inspiration from the Weberian conception of power, defined as "any chance to impose one's will within a social relation, and even in the face of adversity", realists believe that power is essentially the expression of one actor's ability to get another to do what it would not otherwise have done through military threats. According to Aron, "power on the international setting is the ability of a political unit to impose one's will onto other units" 4 . This traditional conception of power is progressively put into question, especially by hegemonic realism, which had the merit of rethinking the definition of power conceived as a bundle of material capacities by realist theories. With this redefinition, power turns into 'hegemony', which imposes a reappraisal of instruments put at the disposal of great nations to exert their leadership. According to Robert Gilpin ${ }^{5}$ for instance, hegemony is not solely grounded into tangible capabilities. In other words, his definition of hegemony is half-way between the pure realistic conception of hegemony propounded by Mearsheimer who simply sees it as material supremacy, especially military supremacy, and the Gramscian theory which defines hegemony as a domination which is not felt as one by those who undergo it.

Steven Lukes' three-dimensional power conception ${ }^{6}$ is interesting in this regard. Lukes holds that power has three dimensions which were identified on the basis of works carried in previous works by Robert Dahl (one-dimensional view), Peter Bachrach and Morton Baratz (two-dimensional view ${ }^{7}$ ). For this author, the most paramount form of power is domination. With the threedimensional view, power can be observed where people are subject to domination and acquiesce in that domination. According to his definition of the concept of power, "A exercises power over B when A affects B in a manner

\footnotetext{
${ }^{4}$ Raymond Aron, Paix et Guerre entre les Nations (Paris: Calman-Lévy, 1962), 16-17.

${ }^{5}$ Robert Gilpin, The Political Economy of International Relations (Princeton: Princeton University Press, 1987).

${ }^{6}$ Steven Lukes, Power: A Radical View (London: Macmillan, 1974).

${ }^{7}$ Peter Bachrach and Morton S. Baratz, "The Two Faces of Power," American Political Science Review 56 (1962): 947-953.
} 
contrary to B's interest." 9 Thus, the three-dimensional view refers to the invisible power which consists in determining other actors' preferences. What matters is to prevent people from having grievances, by shaping their views and preferences in such a way that they accept their role within the social order, either because they cannot expect an alternative, or because they consider it natural and unchanging.

From quite a different perspective, the British scholar Susan Strange, who is a pioneer of International Political Economy, highlights that the weberian conception of power does not enable to satisfactorily account for international power relations in the contemporary world. She developed the concept of "structural power". "Structural power, on the other hand, is the power to shape and determine the structures of the global political economy within which other states, their political institutions, their economic enterprises and (not least) their scientists and other professional people have to operate." 9 She identified four sources: that of security, within which power is based on the capacity to supply someone with protection against threats and on the capacity to threaten someone's security; financial structure, which is related to offer, deny or ask for credit; production structure, which consists in determining the place, means and content of activities aimed at yielding prosperity; knowledge structure, which is based on the capacity to influence ideas and beliefs which are socially legitimate and sought-for and in controlling access to means of communication of the ideas and belief $\mathrm{s}^{10}$.

This latter notion of knowledge structure will impact that of soft power put forward by works carried out by Joseph Nye ${ }^{11}$. From then on, there is a new way of looking at vectors and forms of exercising power according to which power is no more exclusively related to military capabilities. Therefore, geographical and demographic criteria are put into perspective to the benefit of intangible resources such as technology, ideas and culture. Nye will coin the expression soft power, as opposed to hard power, the traditional exertion of

\footnotetext{
${ }^{8}$ Lukes, Power, 34 .

9 Susan Strange, States and Markets: An Introduction to International Political Economy, 2 ${ }^{\text {nd }}$ Ed. (London: Pinter 1994), 24-25.

${ }^{10}$ Strange, States and Markets, 26-30.

11 Joseph S. Nye, Bound to Lead: The Changing Nature of American Power (New York: Basic Books, 1991).
} 
power emanating from the use of classical means of coercion (military and economic). In other words, "a country may obtain the outcomes it wants in world politics because other countries - admiring its values, emulating its example, aspiring to its level of prosperity and openness - want to follow it."12 Joseph Nye's theory tries to show that both types of power coexist, but that the soft power is increasingly central in a world where the most powerful is not so much he who strikes more powerfully but he who demonstrate the capacity of gathering more actors around him, mastering the information, and determining the agenda.

In this study, the paradigm of structural power will be used in a bid to highlight aspects of our first hypothesis. This theoretical approach is advantageous in as much as it goes beyond the discrimination between hard power and soft power by allowing within the same framework classical parameters of power (military force, economic and financial weapons) and modalities for the use of soft power (persuasion, domination value and culture). Furthermore, this approach allows us to have access to international actors as well as non-state actors that, from many perspectives, can be considered as agents of a country's reputation, image, thus power.

\section{Does China challenge the structural power of France in the Francophone Africa?}

Statistics have revealed the extraordinary increase in the interaction between China and African countries during the last fifteen years. Commentators have generally emphasized on the commercial invasion, the unfettered energy frenzy, human rights and good governance. Even if some research have centered on the anthropologic point of view ${ }^{13}$, taking into account French-speaking African countries $^{14}$, no research has systematically been carried out on the impact of

${ }^{12}$ Joseph S. Nye, Soft Power. The Means to Success in World Politics (New York: Public Affairs, 2004), 5.

13 Antoine Kernen and Benoit Vuillet, "Small Chinese Merchants and Entrepreneurs in Mali and Senegal", The China Monitor 42 (2009): 4-6; Mathilde Dupré and Weijing Shi, "La présence chinoise en Afrique de l'Ouest: le cas du Mali et du Bénin," French Development Agency - AFD, Working paper 69 (2008).

14 François Lafargue, "La Chine: stratégies d'influence en Côte d'ivoire," Monde Chinois 8 (2006): 39-48; Vidhan Pathak, "China and Francophone Western Indian Ocean Region: Implication for Indian Interests," Journal of Defense Studies 3 (2009): 79-102. 
interactions between China and the so-called francophone countries until now. Early in 2005, authors suggested that France could hold back China's progress into Africa by identifying its interests and sharing the work with the United States of America ${ }^{15}$. An internal study carried out by the French Ministry of Foreign Affairs shows that Chinese's presence in Africa is essentially a danger for governance and democratization ${ }^{16}$. In the days ahead the China-Africa summit held in Beijing on November 2006, a few prescriptive analyses, with a dose of nostalgia, depicted the Chinese presence in Africa as a threat to France interests. Some wrote: "Good-bye "France-Africa", "Welcome China-Africa!"17

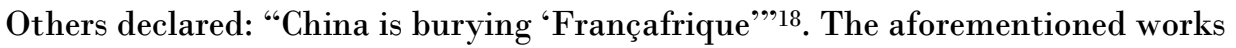
bring out some gaps considering the reality of China's weight on Frenchspeaking Africans countries. First, it can be observed that the commentators almost ignore the historical context between France and its former colonies and territories. In addition, the data seems to be only interested in evaluating power relationship on the material aspect between China and France, and enumerating resources that justify Chinese efficiency. Third, the influence of China in this region derived from the prescriptive method used by the authors. By so doing, they tend to perpetuate the tradition of prospective and prescriptive exercises through which geopolitics is considered as an ideological tool rather than a scientific subject ${ }^{19}$.

In order to go beyond this "declinist literature", we shall focus on structural power. This methodological choice should enable us to include both tangible and intangible elements of power. The structural approach seems pertinent given that France and China actions are carried out in a group of 'Weak states'. A weak state is a country "unable or unwilling to provide

${ }^{15}$ Antoine Glaser and Stephen Smith, Comment la France a perdu l'Afrique? (Paris: Calmann-Levy, 2005), 267.

16 Centre d'Analyse et de Prévision, "La Stratégie Africaine de la Chine," quoted in La Lettre du Continent, July 13, 2006.

17 Yves Lacoste, "La Chine change l" 'ordre' du monde," Hérodote 125 (2007), 3-6.

18 Serge Michel and Miche Beuret, La Chinafrique: Pékin à la conquête du continent noir (Paris: Grasset, 2008), 147-175. Other publications and French Television documentaries adopt a similar perspective, for example: Jean-Marc Gonin and Julien Nessi, "Le triomphe de Pékin," Le Figaro, November 04, 2006; Dominique Dhombres, "Les entrepreneurs chinois en Afrique," Le Monde, January 08, 2009; Serge Michel and Fabrice Monod, "Drapeau rouge sur le continent", France 5, January 06, 2009.

${ }^{19}$ Guillaume Devin, Sociologie des relations internationales (Paris: La Découverte, 2002), 28. 
essential public services, which include fostering equitable and sustainable economic growth, governing legitimately, ensuring physical security, and delivering basic services" ${ }^{20}$. Moreover, we suggest that the persistence of personal and unscrupulous business networks blurs further the comprehension of France's influence over French-speaking African countries.

\section{Assessing the Facets of French and Chinese influences}

\section{On the security structure}

From the security structure point of view, where power is generated from the provision of security, many elements of comparison seem to reveal the weakness of China in Francophone Africa. Apart from cooperation and a scarce military assistance, there is not any direct link between the People's Liberation Army (PAL) and its African counterpart of the francophone area. Nevertheless, the development of a military cooperation centered on mutual visits, sporadic training and bilateral medical exercises is on the rise. The 2007-2008 batch of international training of military telecommunications held in Xi'an, China with the participation of Officer from Gabon and Cameroon is an example ${ }^{21}$. Furthermore, sixty Chinese hospital attendants and medical doctors with their Gabonese fellows attended a "Humanitarian exercise and medical assistance between China and Gabon" called Ange de la Paix 200922. During the past years, the military support to countries which are the focus of our study is unquestionable; this can be illustrated, for example, by the donation of uniforms to the Cameroonian police in 2006, the donation of ambulances and the armored anti-mines to Senegal in $2007^{23}$.

However, France comes to occupy an honorable position according to many factors that deal with the security structure. In Francophone Africa, this

\footnotetext{
${ }^{20}$ Susan E. Rice and Steven Patrick, Index of State Weakness in the Developing World (Washington, D.C.: The Brooking Institution, 2008), 5.

${ }^{21}$ Personal communication with officers from Cameroon and Gabon who participated in the training in China, July 18, 2008.

22 "Arrivée au Gabon d'un groupe des médecins militaires chinois pour un exercice médical," People's Daily, June 18, 2009.

${ }^{23}$ Jonathan Holslag, "China's Next Security Strategy for Africa," Asia Papers 3 (2008), 6.
} 
is unquestionable. Actually, the agreements signed between France and African states in the domain of defense are no longer a matter of military union but a community of destiny rather. "This is because the military cooperation is connected with a certain harmonization of political life and somehow with the existence of common political institutions."24 In order to supervise this policy, France has designed an African framework for military cooperation revolving around the applications of agreements in military and technical support. Practically, this policy is based upon two notions: presence and intervention ${ }^{25}$. The list of these agreements should be associated with a permanent military force whose mission is to assist to intervention force and to facilitate the operations. Thanks to its status of colonial power, France has signed agreements with its colonies in the domain of defense. Considering the conclusion of these agreements, France has the right to intervene militarily whenever necessary. Most of these agreements (Accords de défense) have recently been renegotiated and, it is said that they explicitly forbid France from acting in case of local unrest. This direct link sometimes facilitates the presence of French military advisers. Ivory Coast is an example. In addition, regarding the staff, the French army still maintains several military bases in five African countries (950 soldiers in Ivory Coast, 900 in Gabon, 350 in Senegal, 100 in Chad, 230 in Central African Republic and 2900 in Djibouti) ${ }^{26}$. A sixth country has to be mentioned since in 2013, when the French ministry of foreign affairs announced the establishment of a station of 1000 soldiers who would permanently operate in $\mathrm{Mali}^{27}$. Consequently, France possesses an efficient force of projection in the area of central and western Africa. Asserting of the number of interventions carried out these last decades: 1964, in Gabon; 1968-1972, in Tibesti (Chad); 1977, in Zaire; 1977, in Mauritania; 1978, in Kolwezi (Zaire); 1978-1980, in Chad; 1979-1981, in Central African Republic; 1983; in Chad; 1985, in Chad (against Libya); 1986, in Togo; 1989, in the Comoros; 1990-1993, in Rwanda; 1993, in Zaire; 1994, in Rwanda; 1995, in the Comoros; 1998, in

\footnotetext{
${ }^{24}$ Maurice Ligot, "La coopération militaire dans les accords passés entre la France et les États africains et malgaches d'expression française," Revue Politique et juridique d'Outre-Mer (1963), 517.

${ }_{25}$ Patrice Bakong, La politique militaire africaine de la France (Paris: L'Harmattan, 2012), 42.

26 "Etat des lieux des bases militaires françaises en Afrique," L'Express, December 12, 2009.

27 "Mille soldats français resteront au Mali de "façon permanente"," France 24, April 6, 2013.
} 


\section{Olivier Mbabia}

Zaire; 2002, 2004 and 2011, in Ivory Coast; 2006 and 2008, in Chad; 2008, in Djibouti ${ }^{28}$. More recently, there were the ousting of presidents Laurent Gbagbo and Muammar Gadaffi, and the launching of two military intervention in 2013 (Operation Serval in Mali from January and Operation Sangaris in Central African Republic from December).

It should be noted finally that military equipment's sales and donations within the framework of technical cooperation on the one hand, and the systematic training of Africans junior and senior officers in both French and African schools on the other hand should not be forgotten. Suffice it to remember that two former officers trained in France are now head of states in Africa but also very close allies of Paris in the region, namely President Denis Sassou Nguesso in Congo and President Idriss Deby Itno in Chad.

\section{On the financial structure}

Like Susan Strange notices, the issue of financial structure is considered as the capacity of offering, refusing, or asking for some credits, it is also related to the currency. The Chinese financial structure as opposed to the French one in Francophone Africa seems to be limited. Our emphasis will be laid on the ability of issuing credits given that the target states are economically deprived. In reality, thanks to its budgetary reserved funds, the Chinese government allocated important credits to African countries: 5 billion dollars of preferential loans on the setting up of a Development Fund of the same value; the abolition of heavily indebted and poor countries' debts; 10 billion dollars of preferential loans, of which 1 billion should enable African small and medium size companies to take off, 20 billion lending for development assistance ${ }^{29}$. These important credits, that will contribute somehow to the enhancement of Chinese investment and the development of many African sectors (infrastructures, industrial, agricultural and entrepreneurial) are however short-term measures.

${ }^{28}$ See Raphael Granvaud, Que fait l'armée française en Afrique (Marseille: Agone, 2009).

29 French-speaking African countries present a situation of economic vulnerability and poor socioeconomic development records. In fact, 15 of the selected countries fall among the United Nations category of Least Developed Countries (LDC), of which 10 over 14 countries of the Franc Zone: Benin, Burkina Faso, Central African Republic, Chad, Equatorial Guinea, Guinea Bissau, Mali, Niger, Senegal and Togo. Five countries are not members of the Zone: Comoros, Djibouti, Guinea, Madagascar and Mauritania. 
The real transformation lies on the fact that these credits do not respect the traditional framework imposed by international financial institutions. The vulnerable economies of Francophone Africa countries have always been managed by, and largely depend on, different policies implemented by the World Bank and the International Monetary Fund.

Financially, France enjoys a noble position in relation to the countries that make up Francophone Africa. The two aspects of its financial power are illustrated by the control over the currency used in the Franc Zone and the dominance of France on the banking system of this group of countries. Firstly, since the colonial period, France has been managing the currency of its colonies known as "franc des colonies d'Afrique-CFA" (Franc of African colonies) which has become "franc de la communauté financière d'Afrique". After the independences, the 14 countries of the Franc Zone, of which eight are part of the West Africa Economic and Monetary Union (UEMOA - Benin, Burkina Faso, Ivory Coast, Guinea Bissau, Mali, Niger, Senegal and Togo) and six part of the Central Africa Economic and Monetary Community (CEMAC Cameroon, Gabon, Congo, Central African Republic, Chad and Equatorial Guinea), are obliged to deposit their foreign exchange reserves to the French Public Treasury. This currency, whose convertibility was guaranteed to the French Franc from 1945 to 1999 and to the Euro afterwards, is designed and printed by the Bank of France in Chamalières, a small locality in south-central France.

The shares of trade between France and the countries of the Zone are higher than those with other African regions: above 50 per cent of the national trade in many countries ${ }^{30}$. The reality is that both the Central Bank of West Africa States (BCAO) and the Central Bank of Central African States (BEAC) have monetary policies dictated directly by France and, to some extent, by other countries of the Euro zone. This confirms the weaknesses and the 'servitude' of a group of countries which are unable to independently define their economic and social policies. ${ }^{31}$ Secondly, the domination of French banks

${ }^{30}$ Demba Moussa Dembele, "Mauvais comptes du franc CFA," Le Monde Diplomatique, June 2004.

31 Tchundjang Pouemi, Monnaie, servitude et liberté: La répression monétaire de l'Afrique (Paris: Éditions Jeune Afrique, 1980); Demba Moussa Dembele, "Le franc CFA en sursis," Le Monde diplomatique, July 2010. 


\section{Olivier Mbabia}

over the concerned countries ought to be underlined. A picture of the major banks operating in Francophone Africa and in the Franc Zone indicates the omnipresence of French banking institutions in this geographic area. In this respect, Roland Marchal observes: "The major French banks (Banque Nationale de Paris, Société Générale and Crédit Lyonnais) represent 70 per cent of banking sector activity in the Franc Zone. ${ }^{32 "}$

\section{On the production structure (economy)}

The existence of a vital economy has often been considered as one of the key conditions for a country to be considered a powerful one. The term 'economic weapon' is generally used to denote the use of economic interactions by a state for foreign policy goals ${ }^{33}$. Though, the recent evolution has more or less included actors who claim important positions in terms of authority and exportation of goods besides the state entity. This development leads some scholars to conceive power as: "the ability of a person or a group to influence the results in such a way that their preference should come before others'." 34 If many operators invest different domains of power (namely NGO, legal entities, diaspora, etc.), multinational enterprises are with no doubt those that have mainly focused their attention on the field of economic power ${ }^{35}$. However, these non-state actors do not aim at being an alternative to the State because "resisting, attacking, distorting, combining with, influencing the State is in itself a source of authority, an attribute and expression of power. ${ }^{36 "}$

Within the structure, concerned with activities related to the mobilisation of wealth and prosperity, Chinese companies in Francophone Africa, State-owned enterprises or not, permit to develop successful trade

${ }^{32}$ Roland Marchal, "French Perspectives on the New Sino-African Relations," in China Returns to Africa, eds. Chris Alden, Daniel Large, and Ricardo Soares de Oliveira (London: Hurst \& Company, 2008), 181-196.

33 Marie-Hélène Labbé, L'Arme Économique dans les Relations Internationales (Paris: Presses Universitaires de France, 1994), 3.

${ }^{34}$ Susan Strange, The Retreat of the State: The Diffusion of Power in the World Economy (Cambridge: Cambridge University Press, 1996), 35.

35 On the concept of "Power diffusion", see Joseph S. Nye, The Future of Power (New York: Public Affairs, 2011).

${ }_{36}$ Pierre Buhler, La puissance au XXIe siècle. Les nouvelles définitions du monde (Paris: CNRS, 2011), 284. 
opportunities. Moreover, it is worth mentioning that the Chinese industrial strength attracts many traders and African entrepreneurs, especially Francophone living in China. The latter is thus considered as a place where it is possible to create wealth ${ }^{37}$. Here, the private facet of power allows Chinese, to some extent China, to have a considerable advantage with regard to the role played not only by its commercial diaspora but also its qualified workers. Whereas the former contributed to the booming commercial interactions between China and Africa, the latter participated in numerous infrastructural achievements (bridges, dams, hospitals, factories, sport complexes, roads, etc.). Most of the time, Chinese know-how was needed where local manpower couldn't implement some specific tasks ${ }^{38}$. In fact, this resulted in the extraordinary rise of trade between China and Africa countries in general, from 10 billion dollars in 2000 to more than 198 billion dollars in 2012, according to Chinese statistics. ${ }^{39}$ Among China's major African partners (Angola, South Africa, Sudan, Nigeria and Egypt), there is no country of the francophone region. However, we find Congo ( $5^{\text {th }}$ in 2011) among the major African exporters to China. The latter has indeed surpassed France and the U.S. to become the first commercial partner of the continent. But, when examining the details of this trade relationship, one can observe two facts: it remains modest in Francophone Africa, and the trade value still appears relatively weak compare to the trade interactions between these countries and France. Let consider some statistics of the volume of trade between China and CEMAC countries in 2010: 763.3 million Euro exchanges with Cameroon, 37.1 million with Central African Republic, 2479.6 million with Congo, 841.3 with Gabon, 798.3 million with Equatorial Guinea and 616.4 million with Chad ${ }^{40}$.

Within the Franc Zone, France continues to absorb 25 per cent of countries exports and, thanks to these countries, it realizes a trade surplus with

${ }^{37}$ During my investigations in China I discussed with people (students and entrepreneurs) from Mali, Senegal, Congo Republic of, Guinea and Cameroon living in Shanghai, Guangzhou, Shenzhen and Hong Kong, April-May 2009.

${ }^{38}$ On a construction site in Yaoundé (Cameroon), the Shaanxi Engineering Construction Group Co. had to call 40 boilermakers from China because local craftsmen were unable to professionally accomplish their contract. Interviews in Yaoundé, August, 2008.

${ }^{39}$ China-Africa Economic and Trade Cooperation, prepared by the Information Office of the State Council of The People's Republic of China (Beijing, 2013).

${ }^{40}$ These data and statistics are provided by the European Commission, http://ec.europa.eu/trade/. 


\section{Olivier Mbabia}

Africa $^{41}$. In fact, France commercial balance with Franc Zone countries is highly comfortable. Back to CEMAC countries, in 2011, France has benefited a trade surplus of 710 million euro (see Table 1). If we look at the most dynamic Francophone economies of West Africa, France enjoys a trade surplus of 802.3 million euro with Benin, the first surplus of the Zone and the second on the continental scale ${ }^{42}$. Moreover, while the trade between France and Ivory Coast accounted for 1434 million euro and 794 million euro for Senegal in 2010, China on its side scored 170.7 million with Ivory Coast and 412.2 million with Senegal. In the field, French major firms still occupy prosperous positions: Total, Perenco, Areva, Eramet, Technip in mines and petroleum sectors; Rougier, Thébault Transbois in forest exploitation; Véolia, Vinci, Bouygues, Lafarge, Razel, Dumez, Gaz de France in infrastructure and water supply; and Orange and Alcatel in the sector of telecommunications.

Table 1: France-CEMAC trade statistics (€ millions)

\begin{tabular}{lllllll}
\hline & Cameroon & CAR & Congo & Gabon & Eq. & Chad \\
& & & & & \multicolumn{3}{c}{ Guinea } & \\
Exports & 632 & 43.3 & 488 & 779.6 & 194.7 & 104.4 \\
Imports & 290.4 & 8.6 & 527.7 & 114.7 & 431.7 & 158 \\
Total & $\mathbf{9 2 2 . 4}$ & $\mathbf{5 1 . 9}$ & $\mathbf{1 0 1 5 . 7}$ & $\mathbf{8 9 4 . 3}$ & $\mathbf{6 2 6 . 4}$ & $\mathbf{2 6 2 . 4}$ \\
Balance & 341.5 & 34.6 & -39.7 & 664.8 & -237 & $\mathbf{- 5 3 . 6}$ \\
\hline
\end{tabular}

Source: Regional Economic Service, Embassy of France in Cameroon, February 2012.

Besides merchandise trade, France economical implantation reaps huge benefits from services industry. A particularly significant example is Air France (the French flag carrier) destinations and frequencies to the African continent. Air France possesses a 75 years' presence in Africa, and rounds cities of Francophone countries with 75 flights per week $^{43}$. To date, no Chinese airline

${ }^{41}$ Marchal, "French Perspectives".

42 Direction Générale du Trésor, “Commerce bilatéral franco-béninois en 2011," February 24, 2012.

4310 weekly flights to Douala and Yaoundé; 9 to Brazzaville and Pointe-Noire; 7 to Abidjan, Bamako, Dakar, Libreville and Ouagadougou; 5 to Cotonou; 4 to Lomé and Niamey; 3 to Malabo, N'Djamena, 
company flies to these countries. Hence, Air France has recently created Air CEMAC, the future central African air carrier, strategic company. As partner with the majority of shares (34 per cent) of this sub-regional company it will ensure the choice of aircrafts, define the strategy, launch flights, select and train crewmembers.

If French enterprises have launched the diversification of their markets with the establishment of privileged partnership with countries like Nigeria, South Africa, Angola and Mozambique, they are still well represented in Francophone Africa. These markets remain their cornerstone from which they move to other business destinations over the continent. For instance, the Bolloré Group, which is deeply established in virtually every strategic domain (railways, seaports and logistics) in the Franc Zone, has reinforced its roots in Southern Africa and is now on its way to Eastern Africa via Ethiopia. Incidentally, this evolution weakens trade relationship with Francophone Africa countries. This can be illustrated with the case of Ivory Coast: France's first partner in the Franc Zone, it occupies the $4^{\text {th }}$ rank among France's subSaharan partners in 2010 and the $5^{\text {th }}$ rank in terms of market shares, scoring only 4.6 per cent, behind Nigeria (36 per cent), Ghana (11 per cent), Angola (11 per cent), and South Africa (8 per cent) ${ }^{44}$.

\section{On the knowledge structure}

One of the key instruments that permit to set influence abroad is the knowledge structure, which is conceptually close to Lukes' three-dimensional view of power as well as Nye's soft power. The knowledge structure "comprehends what is believed (and the moral conclusions and principles derived from those beliefs); what is known and perceived as understood; and the channels by which beliefs, ideas and knowledge are communicated - including some people and excluding others." 45 It has been recently argued that Chinese strategic influence centers on seduction in order to attract leaders, elite and young Africans. Focusing on the notion of soft power, authors have generally

Nouakchott and Bangui. In addition, the carrier makes three flights to Antananarivo and seven to Conakry per week.

${ }^{44}$ Ambassade de France en Côte d'Ivoire, "L'économie ivorienne en fiches," March 2011.

${ }^{45}$ Strange, States and Markets, 119. 
enumerated initiatives like cultural promotion, teaching mandarin, Chinese media offensive. In fact, Chinese leaders have shown a great will to influence ideas in Africa through several methods. First of all, comes the promotion of Chinese language and culture: up to 20 Confucius Institutes have open doors to Africa since the first inaugurated in 2005 in Kenya. In 2006, 3737 African students register in Chinese universities, as to 2757 in 2005, an increase of 40 per cent $^{46}$. The number is increasing constantly due to the multiplication of scholarship offered by Chinese government (5500 scholarship pledged in 2009). As a recall, French campuses had in 2005-2006 registered 103235 African students. In the media domain, which is another means of attracting and influencing people, China is not less active. The China Central Television (CCTV) has launched in September 2007 a channel broadcasting in French language for Francophone viewers. As far as the live news channel in English is concerned, CNC World, launched by Xinhua News agency in July 201047, is having auditors in Africa over Anglophone countries.

It is however important not to mistake presence for influence. Today, there are only five Confucius Institutes in Francophone Africa (Cameroon, Benin, Madagascar, Mali and Togo). In addition, no Chinese-promoted radio station or television could pretend cover the francophone area. Moreover, when compared to the number of African students trained in France, the number of students in China is still very low. Since the colonial period, the former displays a strong set of cultural, educational, normative and media institutions to which every former colony pay tribute. It is worth reminding that the power of language imposed during the colonial era is the plinth of that influence.

The first vector concerns the institutionalization of school systems entirely based on the French model. Surprisingly, this pattern is still implemented in the majority of Francophone countries, with few changes. In these countries, there is a vast network of agencies for the teaching of French abroad funded by the French ministry of education. Since these schools welcome local students (from the host and neighboring countries), they do not

\footnotetext{
46 "Les universités chinoises attirent davantage d'étudiants africains," Beijing Review, December 18, 2007.

${ }^{47}$ "China Puts Best Face Forwards with News Channel," The New York Times, July 1, 2010.
} 
only show France cultural merits abroad, but they found multiple affinities with them in the long term. Thus, always based on the sharing of language, Hachette International is the leading (a monopoly) school textbooks publisher in Francophone Africa. Hachette possesses 85 per cent of market shares in school textbooks publishing in those countries via Edicef and Hatier International ${ }^{48}$. As a result, the governments of Francophone African countries do not have any control over the content of this activity: about 80 per cent of the books used by African school students in their country are printed abroad.

The higher education system constitutes the other major components of the mechanism of intellectual influence. In spite of the previous application of drastic consular decisions, the number of African students on French campus is fairly large. During the year 2010-2011 for example, one-third of foreign students in France were Africans. Paradoxically, this number of 100000 increased from 91728 students in 2008, of which 38,714 are Francophone ${ }^{49}$. In addition, France trains large numbers of Francophone leaders and bureaucrats especially in the 'prestigious' École nationale d'administration (ENA). The consequence of this intellectual influence is that the weight of this country within key institutions of Francophone countries is tangible. The Organization for the Harmonization of Business Law in Africa (OHADA) is a good example ${ }^{50}$. If this framework aims at resolving juridical issues within the state members through the unification of business laws, it contributes, even indirectly, to valorize the French law.

Another tool is the cultural diplomacy whose major vectors are the cultural exchange institutions and media. The main objective of this diplomacy is not only to sell cultural works but also to change the way other people perceive $u^{51}$. French cultural centres are likely means of France cultural diplomacy in the world, especially in Africa. Media play an instrumental role on

48 "La France règne en maître sur le marché des manuels scolaires en Afrique francophone," Le Monde, June 10, 2010.

${ }^{49}$ France enrolled 284659 international students. Other main destinations for African students are South Africa (43000 students), United States (34000 students) and United Kingdom (33000 students). See "La France attire-t-elle les étudiants africains," Slate Afrique, May 27, 2012; "La mobilité des étudiants du Maghreb et d'Afrique subsaharienne," Les notes de Campus France 7, October 2009.

${ }^{50}$ The OHADA is composed of 14 countries of the Franc Zone plus Comoros, Guinea and the DRC.

51 Robert Frank, "Diplomatie et transferts culturels au XXe siècle," Relations Internationales 1 (2003): 319-323. 
this regard. Just considering the sharing of French language, one can notice that the French Radio and Television Channels broadcasting abroad have their largest public essentially in Francophone Africa. For this reason, the media of the "Audiovisuel exterieur de la France", namely Radio France internationale (RFI), TV5 and France 24 mark a natural echo in this region ${ }^{52}$. Given to the fact that the vocation of these media is to "break the news with a French vision and to convey French values and perspectives throughout the world", we can consider them as vectors of influence in the hands of their country. This is especially true for RFI. The station was launched in 1931 as 'Poste colonial' (colonial station), today it scores 33.1 million African listeners out of an audience of 45.5 million; 24.5 million of which live in Francophone African countries.

Finally, on the discursive dimension, the device that France cultural diplomacy tends to emphasize is the fact that Francophone Africa can flourish sustainably only in consubstantial relationship with a protector, a kind of hegemon. This process is close to the art of persuasive power (Lukes) whose purpose is to

\begin{abstract}
“(...) prevent people, to whatever degree, from having grievances by shaping their perceptions, cognitions and preferences in such a way that they accept their role in the existing order of things, either because they can see or imagine no alternative to it, or because they see it as natural and unchangeable, or because they value it as divinely ordained and beneficial. ${ }^{3}$ "
\end{abstract}

To put this another way, in a context of asymmetric relationship, the dominated countries in Francophone Africa accept their domination, either by resignation or by accepting its foundations. This process of legitimation, that passes through a control of the media or the socialization processes which aims

${ }^{52}$ Refer to "L'Audiovisuel extérieur de la France": http://www.aefmonde.com/.

${ }^{53}$ Lukes, Power, 24. 
at conquering the hearts and minds, is called 'cultural imprinting' by Edgar Morin. It is considered by Steven Lukes as 'indoctrination' ${ }^{54}$

In this case, the elite (rulers or not) and even some people of these areas, show a particular interest in the French model. We should bear in mind that manipulation strategies exist. Many examples illustrate this trend. The weekly meetings of Ministers in several countries stand on Wednesday morning as in Paris (Benin, Gabon, Ivory Coast, Mali, and Togo). In retrospect, at the end of a visit to France on April 3, 1991, the Cameroonian President Paul Biya congratulated himself to the reporters: "I am among the best students of François Mitterrand!" 55 These common identities denote the significance of the symbolic dimension of the French influence in the region. Following Bourdieu's perspective, the so-called symbolic power is invisible and is mainly carried out by cognitive structures. In other words, it is supplied by the approval of those who bear it because they consider the ruling order legitimate.

\section{China in Francophone Africa: short-term event or systemic shift?}

The presence and power of China in Africa is certainly growing, but since it is the Francophone Africa the region at stake, it is important to determine the limits to this phenomenon. As for the place that China actually occupies under the four facets of power as elaborated above, several indicators tend to confirm the Chinese lateness in some cases.

According to Frederic Charillon, one the myths of the debate on France foreign policy is that the decline is prominent.

\footnotetext{
Often unscientific, this observation of decline may be related to three different perceptions: encrypted declining of France representation in the world, less quantifiable decline in political influence, the decline of the French desire to play a global role and assume a global power position ${ }^{56}$.
}

54 Traité de relations internationales, ed. Gérard Dussouny, vol. 2, Les théories de l'interétatique (Paris: L'Harmattan, 2008), 81.

55 Mongo Beti, La France contre l'Afrique (1993; repr. Paris: La Découverte, 2006), 158.

${ }^{56}$ Frédéric Charillon, La France peut-elle encore agir sur le monde? (Paris: Armand Colin, 2010), p. 46. 
Along the same line, the decline of France in Africa as argued by some commentators with a hint of nostalgia or disappointment may be the result of the success of China ${ }^{57}$.

With regard to security structure, it is not enough to say that the Chinese defense budget (106.4 billion dollars in 2012) is higher than that of France (around 39.52 billion dollars in 2012) or to consider the number of soldiers serving in peacekeeping operations in Africa to conclude that France is in difficulty. It is worthy to note that France is the first to be called for help by Francophone African countries in case of serious security crisis. In reality, France has always been known as the "Gendarme of Africa" conferring it international legitimacy and room for manoeuvre in Francophone Africa. Military operations in Côte d' Ivoire (2011), Mali and Central African Republic (2013-ongoing) perfectly illustrate this state of affairs. Moreover, the legitimacy of France in these interventions is not challenged by allies of the Treaty Organization (NATO) and the European Union, which actually give political and logistic supports. Even China gave its support to France on the intervention in $\mathrm{Mali}^{58}$. It is due to this local, regional, international and also moral legitimation that France prevails over China.

Concerning the knowledge structure and that of finance, it is observed that initiatives supported by the Chinese government are so far limited. The French influence in these areas is immeasurable and can be perceived both qualitatively and quantitatively through declarations, customs, behavior and also artistic production of Francophone Africans.

In reality, the production structure (economy) seems to be the most disputed and the one in which Beijing is likely to assert its competitiveness. In this light, we notice more generally a shift of the center of gravity towards Asia, China in particular. However, China and India are not alone. Other dynamic emerging economies are present too, such as Brazil, Turkey, South Korea and Malaysia. Due to the diffusion of power beyond the State in the production structure, it is neither France nor its Francophone African allies that determine

${ }^{57}$ See Michel and Beuret, La Chinafrique.

58 Zhang Chuanjie and Jean-Pierre Dozon, "Public Perception of China in Francophone Africa," Carnegie-Tsinghua Center for Global Policy, April 03, 2013. 
the place of production of wealth and prosperity. This role is played by other actors of the regional and international political economy. For example, the people look East. Therefore, lays the Chinese strength or asset on its competitiveness. Still, the former colonial power resists holding significant interests in oil and mining, as well as niche markets with the help of mechanisms and unscrupulous business networks closely related to the French State.

\section{Limits of French power in Francophone Africa}

While firmly rooted in the African Francophone zone, the influence of France in the region still seems to face three important challenges pertaining to French's leadership conception of power. The first challenge relates to a loss of direction, that is to say the upheaval of the original context and methods of interaction with partner countries. Outrageous personalization of relations between French leaders and their African counterparts played such interference. Admittedly, the end of the Mitterrand administration ushered in this turbulent era with the disappearance of a privileged partner like Houphouët Boigny of Ivory Coast, and later that of veteran presidents Gnassingbé Eyadema of Togo and Omar Bongo of Gabon, who seem to have surprised France. Personal and secret diplomacy, and the propensity for business intermediaries, with parallel networks (Freemasonry, mercenaries or secrets advisors), caused the dismissal of the Secretaries of State for Cooperation who were asked to leave their function, because they were considered too much reformist by Paris and also by some African presidents (Jean-Pierre Cot in 1982 and Jean-Marie Bockel in 2008). Today, despite official and public declarations, businessmen networks and political friendships remain important and bound to practices and anterior networks. ${ }^{9}$ Indeed, as noted by Christopher Clapham: "What distinguished relations between Africans leaders and France - in sharp contrast to those with

59 Antoine Glaser and Stephen Smith, Ces messieurs Afrique: Le Paris-village du continent noir (Paris: Calmann-Lévy, 1992); Antoine Glaser and Stephen Smith, Ces messieurs Afrique : Des réseaux aux lobbies (Paris: Calmann-Lévy, 1997); François-Xavier Verschave, La Françafrique: Le plus long scandale de la République (Paris: Stock, 1998); Daniel Bourmaud, "Discours de rupture et politique d'impuissance: La politique africaine de Nicolas Sarkozy," in Les politiques publiques sous Sarkozy, eds. J. de Maillard and Y. Surel (Paris: Presses de Sciences Po, 2012), 167-188. 
Britain, the United States, or the former Soviet Union - was the way in which they were incorporated into a network which was intimate in character but international in scope. It provided a means of conducting diplomacy which sometimes more closely resembled the world of domestic politics than that of formal inter-state relations." 60

The second limit appears to be the emergence of competition. Contrary to what is said and written in the media, this competition mainly comes from "allies" and friendly countries like the United States. Actually, France seems now to be losing control to the benefit of the United States. Thus, the FrancoAmerican rivalry explains, to some extent, the relative decline of French influence. In commercial terms, the value of trade between the United States and the countries of the CEMAC in 2010 shows that the US topped not only China but also the 27 European Union countries (including France). And has as important commercial partners there: Congo (2 544.2 million euro), Gabon (1 751.8 million euro), Equatorial Guinea (1 798 million euro) and Chad (1 516.7 million euro). Only Cameroon (329.7 million euro in 2010) and CAR (12.5 million euro) are exceptions. The US position is also visible through a military cohabitation with France in Djibouti, with an increased influence in the Great Lakes region previously dominated by France. In the cultural field, young Francophone elite prefer the American way and are attracted by North America. As a matter of fact, large numbers of Francophone Africans trained in France or Belgium are moving to the US or Canada (Quebec). As Achille Mbembe puts it, "More fundamentally, France is losing a large part of the cultural influence it once had on African elite. (...) The United States is clearly the principal beneficiary of this defection." 61 Exit therefore the sustainability of the de facto arrangement that promoted France as the exclusive guardian of Francophone Africa during the Cold War.

The emergence of "the rest of the world" is a second aspect of this competition. In other words, it is not France which is falling or is being superseded in Francophone Africa but the fact is that the rest of the world

${ }^{60}$ Christopher Clapham, Africa in the International System: The Politics of State Survival (Cambridge: Cambridge University Press, 1996), 89.

${ }^{61}$ Achille Mbembe, Sortir de la grande nuit (Paris: La Découverte, 2010), 98. 
suddenly evolves and races for opportunities in that region (Persian Gulf countries, Turkey, Japan, South Korea, Taiwan, Malaysia, Indonesia, India, Brazil and China). Incidentally, it creates widespread competition between different extra-continental actors increasing ipso facto options for Africans. In addition, there is parallel since the late 1990 s to the reappearance of a SouthSouth perspective that seems fundamentally redefining the current international system. The restoration of this dynamic relationship between southern countries is the result of a growing economic power of emerging countries. ${ }^{62}$

Last but not least, the third limit is the difficulty for the French leadership to make an aggiornamento of their foreign policy style toward Francophone Africa. France seems to continue to confine its action towards the political elite when others put more emphasis on the battle to conquer the "hearts and minds". Limiting itself to these happy few, France paradoxically acts the same wrong way as China does. There is a challenge to adapt, in the sense of resizing its foreign policy tools in order to address the most relevant targets. In a multi-centric Francophone African environment, it is necessary to find the appropriate method for the situation. That is to say, to devise a strategy based on intangible resources of power that affect people, civil societies, the private sector, not one whose unique objective is to rescue corrupt and illegitimate governing elite.

\section{Conclusion}

That China disrupts established equilibrium in Francophone Africa seems undeniable and that such an upheaval allows it to claim a rule is less certain. This is demonstrated in this essay, considering its influence compared to that of the former colonial power, according to the four dimensions of structural power. Donor and emerging market, China is considered as a serious contender in the power of France in Francophone Africa. China also promotes through the

${ }^{62}$ See Alice H. Amsden, The Rise of "the Rest": Challenges to the West from Late industrializing Economies (Oxford: Oxford University Press, 2001). 
Forum of China-Africa Cooperation (FOCAC) unprecedented form of socialization and norms production for these countries. Without neglecting or underestimating the importance of Chinese involvement in Francophone Africa, the light has been shed on how multidimensional presence does not necessarily mean influence. However, it should be noted that the Chinese influence, so smaller it may be, could devote the decline or at least emphasize the relative decline of France in Francophone Africa.

Despite the positive image of China in Africa in general and in Francophone Africa in particular, the 'structural power' of the former colonial metropole remains substantial.

So shall France not be considered as a deus ex machina that would control everything in his former African possessions. Its influence there is also facing several challenges: difficulty to overcome the personal modes of interaction with these countries; the economic and cultural competition of the United States as well as those of emerging countries; the lack of flexibility that hinders a diplomatic shift towards intangible resources of power. Nevertheless, these recent developments seem to have affected only relatively the power of France, which continues to structure the overall coercive, economic, financial, cognitive and cultural environment in which Francophone African countries operate. As for France knowledge power, Jean-Pierre Cabestan, head of government and international studies at Hong Kong Baptist University, points out: "French soft power is bigger than China in francophone countries in Africa. France's relation with French-speaking African countries like Senegal is intimate. China is trying to make inroads in French-speaking countries in Africa, but it's hard for China." 63 In the political realm, there seem to be no concern either. Asked whether France can compete with China, the French Minister of Economy, Finance and Foreign Trade confidently replied: "France is still the second largest exporter to Sub-Saharan Africa behind China but ahead of the United States and Germany. We are also the fourth largest

${ }^{63}$ Toh Han Shih, “Experts Differ on China's 'Soft Power' in Africa," South China Morning Post, July 22, 2013. 
importer after the United States, China and Italy. (...) I do not want to criticize China, I find it obsolete. (...) We are not afraid of the Chinese." 64

64 "Pierre Moscovici: En Afrique, la Chine ne nous fait pas peur," interview by Julien Clémençot and Stéphane Ballong, Jeune Afrique, October 04, 2012. 


\section{Olivier Mbabia}

\section{REFERENCES}

Amsden, Alice H. The Rise of 'the Rest': Challenges to the West from Late industrializing Economies. Oxford: Oxford University Press, 2001.

Aron, Raymond. Paix et guerre entre les nations. Paris: Calman-Lévy, 1962.

Bachrach, Peter, and Morton S. Baratz. "The Two Faces of Power." American Political Science Review, no. 56 (1962).

Bakong, Patrice. La politique militaire africaine de la France. Paris: L'Harmattan, 2012.

Beijing Review. "Les universités chinoises attirent davantage d'étudiants africains." December 18, 2007.

Beti, Mongo. La France contre l'Afrique. Paris: La Découverte, 2006.

Bourmaud, Daniel. "Discours de rupture et politique d'impuissance: La politique africaine de Nicolas Sarkozy." In Les politiques publiques sous Sarkozy, edited by J. de Maillard e Y. Surel, 167-188. Paris: Presses de Sciences Po, 2012.

Buhler, Pierre. La puissance au XXI siècle: Les nouvelles définitions du monde. Paris: CNRS Editions, 2011.

Charillon, Frédéric. La France peut-elle encore agir sur le monde? Paris: Armand Colin, 2010.

Chuanjie, Zhang, and Jean-Pierre Dozon. "Public Perception of China in Francophone Africa." Carnegie-Tsinghua Center for Global Policy, April 03, 2013.

Clapham, Christopher. Africa in the International System: The Politics of State Survival. Cambridge: Cambridge University Press, 1996.

Dembele, Demba Moussa. "Le franc CFA en sursis." Le Monde Diplomatique, July 2010.

Dembele, Demba Moussa. "Mauvais comptes du franc CFA." Le Monde Diplomatique, June 2004.

Devin, Guillaume. Sociologie des Relations Internationales. Paris: La Découverte, 2002.

Dhombres, Dominique. "Les entrepreneurs chinois en Afrique." Le Monde, January 08, 2009.

Direction Générale du Trésor. "Commerce bilatéral franco-béninois en 2011." February 24, 2012. 
Dupré, Mathilde, and Weijing Shi. "La présence chinoise en Afrique de l'Ouest: le cas du Mali et du Bénin." French Development Agency Working Paper, no. 69 (2008).

Dussouny, Gérard, ed. Traité de relations internationales, vol. 2, Les théories de l'interétatique Paris: L'Harmattan, 2008.

France 24. "Mille soldats français resteront au Mali de "façon permanente'." April 6, 2013.

Frank, Robert. "Diplomatie et transferts culturels au XXe siècle," Relations Internationales no. 1 (2003): 319-323

Gilpin, Robert. The Political Economy of International Relations. Princeton: Princeton University Press, 1987.

Glaser, Antoine, and Stephen Smith. Ces messieurs Afrique: Le Paris-village du continent noir. Paris: Calmann-Lévy, 1992.

Glaser, Antoine, and Stephen Smith. Ces messieurs Afrique: Des réseaux aux lobbies. Paris: Calmann-Lévy, 1997.

Glaser, Antoine, and Stephen Smith. Comment la France a perdu l'Afrique? Paris: Calmann-Levy, 2005.

Gonin, Jean-Marc, and Julien Nessi. "Le Trioumphe de Pékin." Le Figaro, November 03, 2006.

Granvaud, Raphael. Que fait l'armée française en Afrique. Marseille: Agone, 2009.

Holslag, Jonathan. "China's Next Security Strategy for Africa." Asia Papers no. 3 (2008), 6 .

Kernen, Antoine, and Benoit Vuillet. "Small Chinese Merchants and Entrepreneurs in Mali and Senegal." The China Monitor no. 42 (July 2009): 4-6.

La Lettre du Continent, no. 498. July 13, 2006.

Labbé, Marie-Hélène. L'Arme Économique dans les Relations Internationales Paris: Presses Universitaires de France, 1994.

Lacoste, Yves. "La Chine change l'ordre du monde." Hérodote, no. 125 (2007).

Lafargue, François. "La Chine: stratégies d'influence en Côte d'Ivoire." Monde Chinois, no. 8 (2006): 39-48.

Le Monde. "La France règne en maître sur le marché des manuels scolaires en Afrique francophone." June 10, 2010. 


\section{Olivier Mbabia}

L'Express. "Etat des lieux des bases militaires françaises en Afrique." December $12,2009$.

Les Notes de Campus France. "La mobilité des étudiants du Maghreb et d'Afrique subsaharienne." No. 7, October 2009.

Ligot, Maurice. "La coopération militaire dans les accords passés entre la France et les États africains et malgaches d'expression française." Revue Politique et juridique d'Outre-Mer (1963).

Lukes, Steven. Power: A radical View. London: Macmillan, 1974.

Marchal, Roland. "French Perspectives on the New Sino-African Relations." In China Returns to Africa: a Rising Power and a Continent Embrace, edited by Chris Alden, Daniel Large, and Ricardo Soares de Oliveira, 181-196. London: Hurst \& Company, 2008.

Mbembe, Achille. Sortir de la grande nuit. Paris: La Découverte, 2010.

Michel, Serge, and Miche Beuret. La Chinafrique: Pékin à la conquête du continent noir. Paris: Grasset, 2008.

Michel, Serge, and Fabrice Monod. "Drapeau Rouge sur le Continent." France 5 Documentary. January 06, 2009.

Moscovici, Pierre. "Pierre Moscovici: En Afrique, la Chine ne nous fait pas peur." By Julien Clémençot and Stéphane Ballong, Jeune Afrique, October 04, 2012.

Nye, Joseph S. Bound to Lead: The Changing Nature of American Power. New York: Basic Books, 1991.

Nye, Joseph S. Soft Power. The Means to Success in World Politics. New York: Public Affairs, 2004.

Nye, Joseph S. The Future of Power. New York: Public Affairs, 2011.

Pathak, Vidhan. "China and Francophone Western Indian Ocean Region: Implication for Indian Interests." Journal of Defense Studies, no. 3 (2009): 79-102.

People’s Daily. “Arrivée au Gabon d'un groupe des médecins militaires chinois pour un exercice médical," June 18, 2009.

Pouemi, Tchunjang. Monnaie, servitude et liberté: La répression monétaire de l'Afrique. Paris: Éditions Jeune Afrique, 1980.

Rice, Susan E., and Steven Patrick. Index of State Weakness in the Developing World. Washington, D.C.: The Brooking Institution, 2008. 
Shih, Toh Han. "Experts Differ on China's 'Soft Power' in Africa." South China Morning Post, July 22, 2013.

Slate Afrique. "La France attire-t-elle les étudiants africains." May 27, 2012.

Strange, Susan. States and Markets. An Introduction to International Political Economy. 2nd ed. London: Pinter, 1994.

Strange, Susan. The Retreat of State: The Diffusion of Power in the World Economy. Cambridge: Cambridge University Press, 1996.

The New York Times. "China Puts Best Face Forwards with News Channel." July $01,2010$.

Valdmanis, Richard, and Andrew Osborn. "CAR President Urges U.S., France to Help Fight Rebels." Reuters, December 27, 2012.

Verschave, François-Xavier. La Françafrique: Le plus long scandale de la République. Paris: Stock, 1998. 


\section{ABSTRACT}

This article seeks to explain the determinants of France influence compared to that of China in Francophone Africa. Focusing on the paradigm of structural power as theorized by Susan Strange, it will attempt to debunk any considerations of a "declining" French influence in Francophone Africa. It will be argued that the existence of "special relationships" manifested through close political and cultural ties but also through covert economic and military networks give onto France the potentials to determine the structure of the regional political economy, in which Francophone African States evolve (hypothesis).

\section{KEYWORDS}

Structural Power; Francophone Africa; China. 



\section{AFRICA AND THE EMERGING POWERS: THE SOUTH AND THE UNHOLY COOPERATION}

\section{Paulo Fagundes Visentini ${ }^{1}$}

\section{Introduction}

One of the most remarkable phenomena of Contemporary International Relations is the fact that Africa became object of a new global race, like in the end of the 19th Century. In the beginning of the 21st Century, however, the most dynamic protagonists of such movement are the emerging powers, and not the European metropolises. Such process occurs in a frame of economic and social development in Africa, besides a diplomatic protagonism, which represented an unexpected feature for many. Africa, in marks of globalization and the end of the Cold War, experienced a second "lost decade", with bloody internationalized civil wars, epidemics (HIV/AIDS, cholera and the Ebola virus, among others) and economic marginalization.

Nonetheless, without due importance given by European powers and the U.S., South Africa, Nigeria and Libya, soon followed by other nations, became more active, and China, India and, shortly after, Brazil started interacting with greater economic and political intensity with the African continent. In addition, they were followed by other emerging powers, such as Turkey, Iran, Russia, Saudi Arabia, UAE and Malaysia, amongst others. The

1 International Relations Professor at Universidade Federal do Rio Grande do Sul. Director of CEBRAFRICA: Brazilian Centre for African Studies. CNPq Researcher. Rio Branco Chair for International Relations at Oxford, 2014. E-mail: paulovi@ufrgs.br. 
effects did not take long, with Africa presenting, since the turn of the century, economic growth rates above the global average. Such phenomenon was accompanied by new diplomatic initiatives and social transformations, which altered the political elements of governance. Although the relative weight of change had limited impact, it was quick enough to be able to rework the hate speech presented by the North towards Africa.

As a reaction, academic and journalistic production began to arise, accusing the emerging powers of "new imperialists" that promoted a "new scramble" for Africa. The explicit speech gets to be surreal: academics, politicians, journalists, businesspersons and activists from non-governmental organizations (NGOs) from former colonial powers and the United States present themselves as defenders of the African people, denouncing particularly the Chinese presence. Not exclusively, however, since Europeans, whose companies are deployed in Africa since colonial times, also criticize the Brazilian presence in Africa, which supposedly would seek only "to exploit the continent". However, critics relatively spare India, although its action is equivalent in form and intensity (Stephan 2006).

Interestingly enough, this speech echoed through the far-left and NGOs, which denounced "Brazilian imperialism" and even "Brazilian racism", while, further paradoxically, many national executives criticized the government for wasting time and resources with "a continent with no economic value and no future". Such opinion fluxes, skillfully supported by companies and governments (through foundations) and globally disseminated by media, have the single goal of delegitimizing Brazil's diplomacy for Africa, constraining its agents (although nowhere comparable to the anti-Chinese policy, much more intense). In this context, this article aims to introduce the topic in order to discuss the elements of such narrative before the reality of South-South Cooperation. The African economic and social development, its integration in global flows (reversing marginalization) and its relatively autonomous diplomacy, all active phenomena in the past fifteen years, represent important elements in the international arena. Thus, in the frame of the developed nations' 2008 crisis, such account finds its raison d'être among the wellintentioned, naive, and economic and political agents with well defined interests (Alden, Large and Oliveira 2008; Ampiah and Naidu 2008; Bond 2010). This point of view is heavily laden by contradictory arguments: today, Africa is 
regarded as irrelevant, just as the emerging countries; tomorrow, emerging powers might cause a huge negative transformation.

\section{Emerging countries in Africa}

The end of the Cold War represented the disengagement of foreign powers and the abandonment of large amount of weapons in the hands of weak governments and insurgent groups without access to power. The struggle for scarce resources, survival and the settlements of previous times produced slaughters from Liberia to Rwanda. The tragedies of the 1990 s were not totally compensated for the (ambiguous) end of South African Apartheid, seeming to vindicate the Afro-pessimistic, with conflicts also involving neighboring countries (Schmidt 2012).

Then, Western attentions turned to the fast-developing Asia, particularly China, without giving due importance to the Chinese increasing presence in Africa. The War on Terror (real or idealized) promoted by the Bush Administration since 2001 kept the alienation in respect to the bonds that were forged between Asia and Africa and to the strong internal inflection that occurred in the evolution of the African continent itself.

At that time, China and India were not only becoming major exporters of manufactured products (requiring raw materials, energy and markets), but the Chinese also withdrew the first 400 million individuals out of poverty line and the latter, 100 million. The overall income increase and the resulting social inclusion both widened consumption and the search for more raw material, food and energy sources. The PR China has never departed from Africa, and SinoAfrican relations, which presented a new economic tone, reflected the Dragon's economic changes. It was not just about trade and investment, but the way China acted and how much it was important for Africa. Quickly and discreetly, China qualitatively increased its presence in Africa, closely followed by India, though it lacked the strategic vision and governmental support brought up by China.

In a surprise fashion, Brazil regained its own diplomatic, economic and cooperative protagonism, especially in relation to Africa, yet surpassing the strong activism exercised during the Military Regime. The African policy of 
Lula exceeded all expectations and Brazil's African policy has become the vector of South-South Cooperation, acquiring a multifaceted profile.

The presence of these three giants in Africa has found a continent where new structures and practices emerged in order to deal with socio-political problems and economic development. The result was rapid, with new economic flows and external policy followed by the action of the new South Africa, Nigeria and Libya, with their abundant resources. At the same time, other emerging powers set a rapprochement, novel or not (but then with a new focus) between themselves and the African continent.

Yeltsin's Russia has ignored its former African allies, but the USSR had left deep roots in various regions of the continent: just as Chancellor Yevgeny Primakov signaled and Vladimir Putin took power, a significantly transformed Russia created an African policy based on economic relations to return to narrower link. In the same vein, Cuba, the Latin American country of largest presence and greatest knowledge and experience in Africa, never abandoned their cooperation, but its military dimension vanished after the end of the Cold War. Its support carried on and, after 1999, the Cubans started to rely on the political and financial support and the association with Hugo Chávez's Venezuela.

However, Turkey, Iran and the Arab countries (especially the members of the Gulf Cooperation Council, particularly Saudi Arabia and the United Arab Emirates), besides minor states like Malaysia, have also been present on the African continent by trading, investing and weaving political alliances. Interestingly, a movement of such magnitude went unnoticed by Europeans and Americans until the outbreak of the 2008 crisis. Henceforth, the Northern traditional powers had not only to seek new opportunities, but also to combat efficient competitors, especially China. The European Union still is the largest economic partner of Africa, but the speed with which China, and other emerging powers, joined African business and created new ones, undermining the old structures of domination, surprised the Euro-Americans (Visentini and CEBRAFRICA 2013).

Whilst a soft power campaign against the presence of China and Brazil - and to a much lesser extent, against India - was launched, the EuroAmericans went on the diplomatic-military offensive, since the financial crisis and the competitiveness of emerging countries (especially China) did not allow a 
purely economic reversal. The rebuilding of the Fourth Fleet (South Atlantic), the creation of Africom (Africa Command) and the "anti-terrorist" militarization of the Sahara by Americans added up to the violent FrancoBritish military intervention in Northern Africa in the wake of the "Arab Spring". Hence, Africa became a pivotal part of great international politics.

\section{China in Africa awakes the African people and the Western Powers ${ }^{2}$}

China has been developing projects in manifold areas since the foundation of its relations with African countries, especially after the 1990s. Oil and other natural resources represent an important part of Beijing's investments in the continent. Facing the developments presented by Beijing, the Western powers set the strategy to control progressively the Chinese access to natural resources, particularly in Central Asia, making China turn itself to developing countries, especially in Africa, which possessed roughly $10 \%$ of the global oil reserves in 2007.

In this sense, Sudan and Angola - which surpassed Saudi Arabia as China's main oil supplier in 2000 - would be among the most relevant African partners, in energetic terms. However, it is important to stress that oil producing countries - like Nigeria and Gabon -, although relying on Chinese investments and participation in the petroleum sector, continue to have Western powers as their main allies, a phenomenon that occurs elsewhere in Africa in many other fields with China. It is largely because Chinese investments are much more diversified when compared to the Western ones, strongly focused on the oil sector.

Beijing has also been developing projects for the construction and establishment of Special Economic Zones and Free Trade Areas in many African countries. The Special Economic Zones, where joint venture companies are installed, started to be developed in the 2006 FOCAC (Forum of ChinaAfrica Cooperation) Summit and, since then, five zones were approved in Sub-

${ }^{2}$ With the collaboration of Guilherme Ziebell de Oliveira, master's candidate in Strategic International Studies at UFRGS. 
Saharan Africa. The investment in economic and free trade zones represent an attempt to reproduce the Chinese development model, since the implementation of zones of these types in China was responsible for the increase of foreign direct investments and the consequent development of the country.

It is also worth remembering that some African countries have recently passed through internal conflicts, which destroyed a large part of their infrastructure, like Guinea-Bissau, Angola, Democratic Republic of the Congo, Sierra Leone, Liberia and Côte D'Ivoire. Thereby, a significant part of Chinese investments in the continent is focused on the construction or reconstruction of countries' infrastructure, generating thousands of posts of employment, though China employ its own workforce for many times, causing localized tensions (but reducing costs and allowing to operate in a minimal profit rate of $3 \%$, unlike the European 15\%) (Brautigam 2009, 247). Many public edifices were built, as well as football stadiums, energy-producing plants, roads, schools and centers for agriculture development. Hospitals were also built by China, which have been providing capacity building and formation for doctors and many other local professionals. The construction of infrastructure and the training of African employees are fundamental aspects of the Sino-African relations, once they focus on the African necessities for modernity and dignity, much less emphasized by Western vision.

Other important point is the financial aid provided by China to African countries. Differently from the West, China does not impose political demands and conditionalities on the recipient nations. Still, most of Chinese aid is completed through infrastructure building, and not through payments made directly to governments, significantly avoiding the misappropriation of funds and corruption (Sautman and Hairong 2006, 58). Moreover, unlike the international financial organizations, the Chinese financial aid is very dynamic, being available in a much faster period, flattering African leaders.

The interaction between China and Africa changed the economic panorama of the continent. Beyond the investments, the aid projects and the infrastructure construction, the huge Chinese demand for commodities enormously favored the African economies, transforming growth from possibilities into a real improvement and contributing for the expressive economic development of Africa in recent years. The capitation of currencies 


\section{Paulo Fagundes Visentini}

through commodities exports, for example, allows the African states the emancipation from IMF.

The African population is of roughly one billion people. Considering that a large part of it subsists from the production of commodities that, thanks to the Chinese expansion, suffered a strong escalation of prices, causing the increase of the purchasing power of the African population, an improvement of the pattern of consumption in Africa can be observed, turning the continent into a new market for China and other nations. Furthermore, the Chinese products sold for Africa, besides possessing affordable prices, have the capacity to increase the standard of living of African consumers. Thus, there is a commercial balance between Africa and China.

In political terms, the Sino-African interaction significantly benefits both Africa and China. For African people, the Chinese support aggregates a heavyweight partner in the pursuit for a more active participation in the international forums. Besides, once China is a permanent member of the United Nations Security Council, the African countries have a strong ally against some Western initiatives, negative for African countries. The relations with Beijing proportionate a kind of economic decolonization and a new international projection for Africa. The Chinese participation in the continent presents itself as positive to the extent that it creates new opportunities and possibilities, both politically and economically, with the increase of the number of possible partners and the competition between them.

Chinese presence in Africa, like the politics and the development model in China, presents itself enigmatically. There is no politics without interests, and China has particular interests in Africa. Many of them are the same of the Popular Republic's militant era, though they are not only connected to Africa, but equally to the change of an international system dominated by the West. The Third World has always been a key piece of the Chinese strategy of alteration of the world order. What is new is the economic dimension.

China does not "plunder" the continent because it is not in a position of imposing itself before the African people (and it would not long for such thing). It also pays for what it buys (reverting the price decline), besides representing a model for Africa through its successful progress and poverty eradication, for China still is a developing country even though it is a permanent member of the 
UNSC. The Chinese make donations for lost funds, cooperate in all spheres, do not meddle in African internal affairs and sell consumer goods for very low prices, accessible for many social strata deprived heretofore of them. It is causing a social transformation from the base, with economic and political impacts. The African consumption affects the capitalist model currently in force at the global level. The Chinese presence is still a minority, and the country does not put in practice any activity not demanded by the African nations.

The economic flows between China and Africa increased from 10 to 200 billion dollars in 10 years, and $25 \%$ of the oil imported by China come from the African continent. The relations between both actors is similar to the link China kept with Japan in the 1970s, during the Oil Crisis and the recession of OECD countries, only with reverted roles, for Chinese used to receive investments in infrastructure, acquired vehicles and other goods, while exporting oil and coal to Japan. Through the sale of commodities, China paid for imports and amortized investments without becoming indebted, which was highly advantageous for both countries.

One problem is that Africa has not a particular negotiation policy, because there are 54 states. It is Africans' responsibility to improve their arrangements within multilateral institutions, like African Union, to negotiate with the Chinese ${ }^{3}$. The West has short-run policies for Africa, but China acts in a long-run perspective, though with a flexible strategy. According to Yu (2010, 150), "China [is the] 'Dragon in the woods', [which] needs to be unknown and not understood. However, Africa understood it and the Western countries often reckon that China possess capacity, experience and technology to contribute for the African economic transformation".

\footnotetext{
${ }^{3}$ The multiplicity of Chinese agents in Africa makes their control problematic for Beijing. Abuses, which happen in every relation, involve links between Chinese and local authorities (limber and ivory contraband, for example). In respect to the labor question, there is a cultural problem: the China that enters the African continent is engaged in a swift growth, which contrasts with the situation faced by Africa, generating a clash between completely different time dimensions. The Chinese eagerness to conclude the works in time and with a payable cost deprive interpersonal relations of a human aspect that is much expensive for African culture. Moreover, the diversity and quantity of fronts in which the Chinese are involved make eventual problems even more frequent and easily explored (when not broadened) by international media, with aims at (de)forming the local and external public opinions.
} 
Another important question, of global impact, is that Sino-African relations are remarkable features of South-South Cooperation, and they are contributing for creating a southern geopolitical space, in which the South Atlantic and Indic oceans acquire a strategic role in the political and economic fields (Kornegay 2010). China has become an industrial power, but not a superpower, continuing to be a developing country. It makes a huge difference for Africa, if compared to Europe or the United States. In this sense, the Western critiques just confirm the hypothesis that Sino-African cooperation creates a situation of decreasing Western importance. The valuation of the African space changes the world balance of power.

\section{The resumption of Brazil-Africa relations and its geopolitical effects}

Brazil is a mixed country, a multiple and still-forming culture with a strong African component. It joined the world-system during the slavery mercantilism along with Africa, turning the South Atlantic into one of the most dynamic centers of the world-economy during the seventeenth and part of the eighteenth centuries. In spite of this common identity, British diplomacy prevented Angola to integrate Brazil at the latter's independence in 1822. Throughout the nineteenth century, Great Britain cut the transatlantic ties (especially the traffic) and, during its imperialist phase, occupied much of the African continent (Rodrigues 1964; Munanga 2009). From 1860 to 1960, Brazil-Africa relations were minimal, and it was only with the Independent Foreign Policy (1961-64), the Military Regime (1964-85) and the Sarney administration (198590) that the political-economic interaction gained new intensity. The 1970s and the 1980 s were decades of large commercial interchange (greater than currently) and political rapprochement.

However, the Third World's debt crisis and the end of the Cold War affected Brazil and Africa, restraining interactions between them both. After the retreat of the neoliberal adjustments period on both sides of the Ocean (1990s), when there was only a selective approach (prioritizing some key countries), cooperation was resumed quantitatively and qualitatively, in a multidimensional frame, during Lula administration (2003-2010). At this stage, Brazil seeks no mineral raw materials or food in Africa because it is a major 
exporter of the same items and is on track to become an exporter of oil. Three main relationship lines gained remarkable boost.

Firstly, an intense political and diplomatic approach, bilaterally and multilaterally, aiming to influence the evolution of world politics, where President Lula's protagonism was decisive. It was not only a search for support to a permanent seat at the UN Security Council, but also the formation of a cohesive group in the political and commercial negotiations at international organizations such as the WTO. Moreover, Brazilian diplomacy sought to strengthen Africa's international role and pushed for the creation, within the South-South Cooperation framework, of the IBSA Dialogue Forum (India, Brazil and South Africa), and of the triennial summits South America-Africa and South America-Arab Countries. Besides, Brazil gave a new impetus to the Community of Portuguese Language Countries (CPLP, initials in Portuguese), and the Zone of Peace and Cooperation in the South Atlantic (ZOPACAS, initials in Portuguese).

Secondly, in the economic sphere, it intensified the trade of goods in both directions (slightly favorable to Africa) and Brazilian investments in infrastructure and services, with the debt forgiveness of various countries and financial support from the National Bank for Economic and Social Development (BNDES, initials in Portuguese). Such initiatives aimed not only to internationalize Brazilian big companies that were in Africa since the $1970 \mathrm{~s}$ (Petrobras, Vale do Rio Doce, Odebrecht), but also to increase trade in both directions. The creation of political, financial, institutional and logistical channels for the exchange's sustainability was fundamental. It is important to mention that there were great business prejudice and resistance from certain domestic and foreign actors to such cooperation (IPEA/BM 2012).

Finally, in third place, South-South Cooperation had an enormous improvement in the technical, educational and social fields. The Brazilian government's successful social policies drew Africa's attention: combating hunger, eliminating poverty and epidemics (such as HIV-AIDS), and supporting youth, women, education, sports, culture and public safety. With regard to technical cooperation, Embrapa and other agencies' work contributed for the development of agriculture from the large to the domestic scale. Technical education, transports, energy, urban planning, sanitation, biofuels 
and health, among others, are fields in which the performed work is strongly recognized by Africans and the international agencies (Mendonça Jr. 2013).

If all these processes and developments represent only political discourse (prestige diplomacy), economic interests ("soft imperialism") or an association between two peripheries of the world-system in the pursuit of socioeconomic development (South-South Cooperation), time will show. This is an ongoing process with many stakeholders, multiple objectives and a complex regional and global environment.

African governments, in turn, must overcome the conduct of external assistance and dependence, created during the Cold War and intensified during the "lost decade", as well as to seek deepening the processes of development and integration under the challenge of globalization. To vanquish some aspects of the colonial legacy - especially the fragmentation of countries, mainly observed in the setting of small and unviable nations - is an urgent need. At the same time, they have to strengthen the ties of cooperation, in an independent external perspective, reversing the trend of marginalization of the continent.

Brazil, on the other hand, is a mixed country, not a "racial democracy" or a "multicultural" nation. Miscegenation does not mean bleaching, but mixing, something that has to do with a culture that ignores certain differences and feels strongly attracted by other cultures. The country is seeking an identity and developing its own culture, in which the African element has a definite contribution and should be recognized, and social inequalities that penalize the majority of the black population are the subject of affirmative action policies and tend to be at least minimized. Yet, among many injustices, we have a huge culture of tolerance, which can be a model for a world of intolerance (Cardim and Dias 2011).

\footnotetext{
4 The expression "racial democracy", often invoked by critics (always invoking Gilberto Freyre) of the cooperation between Brazil and Africa as a hypocrisy, never surpassed an internal political and diplomatic discourse of short duration. One must separate the academic Gilberto Freyre from the opportunist, ally of Portuguese Salazarism, and remember progressive historians such as José Honório Rodrigues, who presented the qualities of a mixed country. The concept of "multiculturalism", based on North American anthropology, was introduced in Brazil in the 1970s and 1980s by domestic and foreign critics in the zenith of both cooperation with Africa and struggle for democracy. It seems that its objective was to delegitimize the Brazilian diplomatic discourse and to substitute the centrality of the social class' concept for the race's, with the aim of disarticulating the increasing social conflicts that followed the end of the military's "economic miracle."
} 
Far beyond the commercial aspect, Brazil can be an important partner for the African continent to surpass some internal obstacles (political, economic and social). The barriers of Africa, in turn, may also be useful for Brazil, not only in economic aspects, but also political and cultural. As a developing nation, there is always a kind of "First World temptation" by Brazilian elites, who see the country as "a white, Western and Christian" state. Moreover, our society, which receives African students, should also send students and tourists to Africa, which would contribute to the development of Brazilian national identity, the essential element of any development process.

Finally, the tension between a transoceanic cooperation focused on the North Atlantic (due to the history of capitalism) and another centered in the South Atlantic (based on South American integration, in association with Africa and South-South Cooperation) is a fundamental contradiction. In this context, the Brazil-Africa relations are crucial to overcome such limitation. The integration of the North Atlantic is already completed and many analysts focus on the rise of the Pacific Ocean region. However, few realize the importance of emerging oceanic spaces in the South Atlantic and Indian oceans, the route that connects Brazil to Asia. Most of the oil from South Africa and Southern Asia is in these two oceans. It is vital, therefore, to defend the sovereignty over these natural resources and demilitarization and the security of these strategic routes. Hence, it is possible to understand the logic behind the IBSA strategy and even the Brazil-Africa relations.

Obviously, Brazil's stand regarding the African States have allowed a worldwide projection of the country's image (prestige diplomacy). However, it is important for both sides, once the bilateral relations and the common multilateral action are fundamental to boost African states' international performance. Besides, they contribute to the emergence of a multipolar order, as well as to vanquish the past challenges and to balance the opportunities of European and North American cooperation with new ones, provided by the Indian and Chinese presences. This represents a primary condition for the social and economic development of Africa.

At the same time, as a capitalist country, the Brazilian business community wants to gain profits, especially in new markets (then the concept of soft imperialism). Nonetheless, the historical experience shows that just political will and solidary rhetoric are insufficient without solid economical 
connections. The recent political evolution shows, on the other hand, that African governments are becoming more pro-active in the defense of their interests. Brazil, thus, is not in position of imposing a condition the Africans do not want. In the same way, China and India have no conditions to "dominate" Africa.

It is evident that Lula administration had a wider approach for SouthSouth Cooperation and tried to propose a new shape for international system. It was not the case of asking developed countries for a new form of treatment, but of not doing the same to the least developed partners. It was coherent with the social and political programs of Lula and Dilma. Neither was it the old Third World's 1970s strategy - a coalition against the north. The post-Cold War and globalizing scenario has produced a new international environment, in which Brazil needs consistent partners to a construction of a multipolar world order.

Finally, Brazil-Africa relations gain even more importance in the recent context of world financial crisis, in which the commodities' price drop and the decrease of foreign investment fluxes threaten the developing countries. It is, therefore, a critical moment for partnerships with African countries, because there is not only the potential for a tighten relation, but also for a rupture. According to Lula's posture in forums - the III IBSA Summit, the Financial G20 and the UN General Assembly -, the president was interested in the first option, tending to maintain the most important foreign policy lines through diplomatic efforts, in order to deepen relations between Brazil and developing countries. As affirmed by the president during the XXIII African Union Assembly, in July 2009, "Brazil has not come to Africa to apologize for the colonial past; we want to be real partners in development and cooperation". In the occasion, he promised to help Africa to promote a Green Revolution in all agricultural fields.

It would not be an exaggeration to consider Brazil's foreign policy towards Africa as a Revolution. During the July 2010 FIFA World Cup, Lula made his last trip to Africa as president. He visited Cape Verde, where he watched the CEDEAO/ECOWAS-Brazil Summit Meeting to promote cooperation with West African countries. Then, he traveled to Guinea-Bissau, Equatorial Guinea, Kenya, Tanzania, Zambia and South Africa. In Kenya and Tanzania, agreements were signed with Vale do Rio Doce and Petrobras. 
Between 2003 and 2010, Lula travelled 11 times to Africa, visiting 29 nations, while Brazil received 48 African Chiefs of State. Brazil has opened 17 new embassies in Africa, totaling 35, standing in the fourth position, right after the U.S., France and China. Never has so much been done for Brazil-Africa relations, while Dilma is keeping the same path, although in a difference conjuncture ("continuity without priority").

\section{India, Russia and other emerging powers also reach Africa}

Like China, India has maintained millennial contacts with East Africa, which were interrupted while both suffered from common colonialism. A significant migration of contracted Indian workers has also occurred, though. From India's independence until the end of the Cold War, neutrality, anticolonial policy and the antiapartheid diplomatic support were the guidelines of India-Africa relations. Since the $1990 \mathrm{~s}$, globalization and Indian development and economic openness created a new stage for cooperative relations, which has a smaller governmental support from Delhi if compared to Beijing. Moreover, India seeks maintaining a low political profile and a predominantly economic acting, though Indian diplomacy's long-run objectives were not changed, just reshaped.

The most remarkable point is that Indian actions are rarely subject of Western critiques, though they are not much different to Chinese or Brazilian practices. In any way, India contributes to African development, where it seeks energy, raw material, food and markets, offering cooperation and investments. In the absence of a well-defined policy, India follows China's path, with the difference of being a member of IBSA and sharing with the Africans the Indic Ocean's ascension as a strategic space (Beri 2003; Mohanti 2008).

Czarist Russia maintained relations with coopt Christians from Ethiopia and Egypt, as well as an anti-British policy similar to the African. If the Russian Revolution, on the one hand, represented a physical drift away from Africa, on the other it presented a strong anti-imperialist policy that flattered the Africans. Moreover, Africa sent some individuals to the formation of the Communist International and, after the Second World War, to Eastern Europe and the Communist Parties of the metropolis, which kept indirect contact with the USSR. 
Moscow developed an intense anticolonial policy as a permanent member of the UN Security Council, and extended its cooperation to the first independent states of Africa. In a less-known continent, the participation during the Congo Crisis represented a trauma. Besides, the uncertain situation of progressive regimes, such as Ghana, Guinea and Egypt, caused a Soviet retreat, despite the continuing cooperation with the continent. The Soviet anticolonialism also suffered from contradiction with its European policy during the Cold War, like the relations with France, for instance.

Nonetheless, with the situation of the Portuguese colonies after the Revolução dos Cravos and the Cuban involvement, as well as with the Ethiopian Revolution, Moscow had to position itself in support to its allies and against the Sino-American influence towards Africa. Fifteen years of war in the South and the Horn of Africa would follow, with indirect participation of the Warsaw Pact (arms, assessors, economic and diplomatic support, and political formation) and direct participation of Cuba (combatants and cooperation). Such involvement helped forming new African elites - military, bureaucrats and technicians, which contributed to state and nation building, and to international projection (Hughes 1992). However, this whole process was interrupted with the end of the USSR, and the 1990s were marked by an estrangement during the Ieltsin administration.

With Putin, Russia re-emerges as an economic partner aiming to invest, more than just to import, in energy and minerals, besides retaking its military contacts to sales and improvements of equipment. However, Russia also contributes to infrastructure, cooperates in a myriad of traditional fields and becomes an ally at multilateral forums, trying to qualify African states to participate of the building of a multipolar world order (Fidan and Aras 2010).

Cuba was included in this article not because it is an "emerging" country, but because it represents the Latin American nation with the longest and steadiest presence in Africa, where Cuba exerts great influence, however not economic. Like Brazil, it is a mixed country with large African component. Even prior to the Revolution, there were intense contact, simultaneous to the independences, with Africa activists. Excluded from Latin America and with a complex relation, not immune to contradictions, to the communist world, Cuba approached the Third World, especially Africa. There, Cuba supported the 
national liberation movements, cooperated in the social field with the new nations and formed technical and political personnel in Cuba. In 1975, the Cubans started to possess a military-strategic presence in the South and the Horn of Africa.

The Cubans guaranteed Angolan sovereignty and the defense of the Ethiopian Revolution, as well as Namibia's independence, but Cuban troops left Africa in 1989. Medical, technical and educational cooperation continued, though. Even with its economic crisis, Cuba kept aiding and hosting thousands of African students. (Lopez 2002). In the beginning of the $21^{\text {st }}$ Century, its situation improved and it opened an association with Chávez's Venezuela for a high-level diplomacy for Africa. The new South Africa represents an important ally thanks to the old partnership with African National Congress.

Turkey had a historical presence in Northern Africa, though it is not perceived as colonialist. In 1998, with the victory of the Justice and Development Party (AKP), of Islamic orientation, an Action Plan for Africa was created. A nation with certain industrialization level, Turkey is a regional power and possess a new and active diplomacy. It stopped having in the European Union and the NATO membership (USSR no longer exists) its only vectors of foreign policy. The Turkish Doctrine of Strategic Depth aimed establishing leadership and influence ties to Muslim states, especially in Africa. Besides commercial and investment ties, Turkey has been granting great emphasis to the Somalian question, which guaranteed the country a lot of prestige in the African continent.

The Gulf Cooperation Council (GCC), particularly Saudi Arabia and the United Arab Emirates, along with the Islamic Development Bank (founded in 1973), aims investing in Africa, preparing for the post-petroleum era. It is not about "emancipating the continent", since they exclusively focus on business, occupying the empties left or neglected by Euro-Americans, and the PetrolMonarchies are allies of the Western countries (though they start to develop some different interests). Their actions, however, are of great contribution to the African development.

On its turn, Iran, which during its imperial era maintained certain contact with Africa, emerges negotiating oil by a cheaper price, exchanging products and investing in the continent, besides an intense political cooperation. It represents an effort to overcome the isolation provoked by the Western 
sanctions to the country, as well as the exercise of a diplomacy directed to the emancipation of the Third World, which has always been a motto of the Iranian Revolution. Currently, Iran is one of the leaders of the Non-Aligned Movement. The discrete, but relevant and increasing, presence of Malaysia, also worth a mention. An officially Muslim country with a typical business diplomacy, Malaysia has an emerging nation profile that is very similar to the aforementioned states. However, it avoids any specific political discourse for the African Continent apart from the South-South Cooperation.

\section{The encounter between periphery and semi-periphery: effects}

At the structural level, the presence of emerging powers such as China, Brazil and India, Russia, Cuba, Turkey, Iran and the Gulf Arab nations, Africa relies on ongoing change in global capitalism. Industrialization spread by the semiperiphery of the world system, especially in East and South Asia. However, it is important to note that without economic connections, no system of international relations. Nonetheless, the world political system is also undergoing changes with the relative decline of the economy and even the power of traditional military-diplomatic powers of the North Atlantic, and these conditions are necessary to explain the new phenomenon, are not sufficient.

This set of new relations was not the result of chance, cyclical economic opportunity or simple political voluntarism. The transformation of global capitalism, industrialization had brought to the Asian Tigers and China, and other emerging nations such as Brazil and India, now allow these countries to invest and trade with Africa. However, it is not a mere economic logic that connects the semi-periphery to periphery: there is a political dimension and the emergence of a new socioeconomic paradigm that were not part of the calculations of policymakers, entrepreneurs and speculators of the North Atlantic. Great production and technological progress in creating conditions for the emergence of alternative political, diplomatic and social projects in the context of long-term history in the five centuries of expansion of Western Empires Maritimes give rise to the recovery of large land areas and "continental empires." 
However, it is necessary that the countries in question have projects and political will to promote economic globalization and political and social cooperation with other regions. Many attributed the presence phenomenon emerging in Africa to an "exceptionally favorable conditions in the global economy" without any particular merit. But such a situation, if it ever existed, has passed, but cooperation with Africa remains strong, to the point that the old powers have sought to employ diplomatic and military resources to bar the way of South-South cooperation for Africa.

Africa, a huge and underpopulated continent is the last space with strategic resources and under-used, still under the influence of declining economic powers. This is the space that opens a new dispute between powers, but called "new race" or "new share" is not based on established exclusive areas of direct control, as in the past. It is aimed at specific sectors of the entire continent, which today is characterized by a number of nations in the process of consolidation and political will own economy.

The Africans and their new partners gain greater diplomatic role, with the new international relations marked by the South - South cooperation and the building of a world system characterized by increasing multipolarity, which advances as the development of the periphery is consolidated. China is the most important part of this process, quantitative and qualitative factor, which favors the presence of other emerging markets. China, Cuba and have never stopped cooperating with Africa, since 1949 and 1959 respectively.

The USSR started cooperation in the passage from the 1950 s to 1960 , suffering a setback to the mid-1970s, when it acquired high profile. With its decline and implosion, followed almost a decade of absence, until Putin's Russia, in 2000, resumed cooperation, this time with an economic profile and with increasing intensity. The Turks, Iranians and Arabs came later, although the latter have had some cooperation in the decade that followed the 1973 oil crisis.

Currently, we observe the continued presence of the emerging powers, but amid a Euro-American counteroffensive since 2008. The question is that African states, even with the creation of the African Union in 2002, do not have a consolidated common policy, nor a defined developmental project set on a continental scale, although if it has been sketched. The big issue is whether its cooperation with emerging countries will resist to the new Western offensive. 


\section{Paulo Fagundes Visentini}

There is strong evidence that such link is going to persist, but there will be major changes in the current contours.

China had ancient contacts with Africa five hundred years ago, which were interrupted (except for the presence of immigrants hired to work fronts), and the Asian country suffered colonialism the same way as Africa, creating a common vision. The Chinese Revolution, the Bandung Conference and the anticolonialism set the conditions for a new cooperation, with diplomatic, revolutionary support and cooperation in the spheres of social base. Although poorer than the USSR, China has disbursed more resources on Africa than the latter until the Cold War reached the continent during the 1970s. This phase was marked by the internal problems, pro-West external alliances and the economic transformation that provoked a decrease on the cooperation and Beijing's adoption of alliances that drifted China away from most Africans.

Nevertheless, in the 1990 s, returned to China with technical cooperation and growing economic interaction, since its development and transformation of the world order so require. Though he denies, China has a strategy for the continent, which aims to develop both and closer diplomatic cooperation as a way to transform the world order towards multipolarity and strengthening of multilateral organizations, especially the UN. China seeks raw materials, food, energy, markets and political support, offering cooperation basis (including grants), infrastructure construction (via help or paid by Africans), makes investments, contributes to the economic emancipation of the continent and works together in international organizations, almost always in support to the Third World.

Brazil had strong interaction with Africa in the colonial period and the nineteenth century, along with Cuba, the only emerging with strong population of African origin. But Brazil's cooperation with Africa was only resumed with the Independent Foreign Policy (PEI) in 1961, and consolidated during the military regime (1964-1985), decreasing during the 1990s and being resumed with great intensity at the beginning of the century XXI.

The Brazil-Africa cooperation, in addition to ASA and ASPA Summit, another multilateral dimension involves transcontinental range, the IBSA Dialogue Forum, which is an elaborate South-South cooperation form, reactivating the size of Brazilian diplomacy in the Third World. You can 
compound the connections of strategic emergence of the South Atlantic, which has a strong interface with the Brazil - Africa relations.

While social and economic development, coupled with the political autonomy of Africa, are political components of the government led by the Workers' Party, they are needed to change the international system and the deepening of ties between Brazil and Africa conditions. In addition, the relationship contributes to the definition of Brazilian identity as a Third World nation (although linked to the misconception of "multiculturalism"5), instead of the idea of elites belonging to the Western world, read, white and Europeanized.

As African nations, Brazil is a developing country. Hence the aggressive way the Brazilian elite fighting African policy initiated by the Lula government. During the Dilma administration, the relationship with Africa has lost importance, but priority and prominence. The President does not have the same interest in foreign policy, which he considered "too advanced" and consolidated, giving greater autonomy to the Foreign Ministry and focusing on combating the crisis and in building the infrastructure. There is continuity, but the future will show which Africa's place in the future world insertion of Brazil.

Finally, the diplomatic and military response Euro-American (and Israeli ) aims formally to combat terrorism, but also to business, to weaken the presence of emerging powers in Africa, and ensuring a strategic edge for right reflux in the Middle East, to control the South Atlantic and Indian Oceans as well as the stabilization of Europe's southern frontier. The Israelis seek to avoid isolation in the region, where the Western presence declines. The static figures point to the Euro- American supremacy on the African continent, but its evolution shows that, as a whole, emerging become a growing force, not only for themselves, but also for contribution to African development.

5 There is a wrong idea in the country simplistically linking the question of the Afro-descendants in Brazil to Africa's situation: both would be "the oppressed." In Brazil, the analysis of class is switched by the analysis of the race, just like the North American anthropology, which introduced the concept of "multiculturalism" since the 1970s. On the other hand, while the elite opposes the Brazil-Africa relations, the "Left" believes that we should "pay the historical debt" of slavery, without considering that the European states promoted this process. Well, the African nations are capitalists, and it is with them that Brazil must negotiate, which does not mean that the affirmative actions are not directed for the change. 


\section{Paulo Fagundes Visentini}

The phenomenon described in this article occurs in the framework of global capitalism, with Africa through a process of capital accumulation and the formation of different social classes, the modern type. However, it is already marked by a visible political impact on the countries most advanced in the process, as South Africa is important to remember that African leaders and significant social groups are key actors in such interaction, which falls within the framework of one inter-capitalist competition on the world stage. On the one hand, as has been seen, the South-South Cooperation empowers the political and economic development of African countries, with impact on the global reordering. Then, a deepening of capitalist social relations of its kind in Africa, which creates political and social cleavages involving the development of alternative projects internally, with possible breaks in the medium and long term, occurs. This modernization of the African continent allows such future possibility, unlike the naive defense of corporate pre -capitalist in the region, supported by some social actors default. 


\section{REFERENCES}

Adebajo, Adekeye; and Kaye Whiteman (Eds.). 2012. The EU and Africa. From Eurafrique to Afro-Europe. London: Hurst \& Company.

Adebajo, Adekeye. 2010. The curse of Berlin. Africa after the Cold War. London: Hurst \& Company.

Alden, Chris; Large, Daniel; and Ricardo Soares de Oliveira. 2008. China returns to Africa. A rising power and a continent embrace. London: Hurst \& Company.

Almeida Filho, João Genésio. 2009. O Fórum de Diálogo Índia, Brasil e África do Sul. Brasília: FUNAG.

Ampiah, Kweku; and Sanusha Naidu (Eds.). 2008. Crouching Tiger, Hidden Dragon? Africa and China. Scottsville: University of KwaZulu-Natal Press.

Anshan, Li. 2008. "China's New Policy toward Africa". In China into Africa: Trade, Aid, and Influence, edited by Robert I. Rotberg, c. 2. Washington: Brookings Institution Press.

António, Nelson. 2011. China and Portuguese speaking Africa. Lisbon: Ed. Sílabo.

Banco Mundial; andIPEA. 2012. Ponte sobre o Atlântico. Brasil e África Subsaariana: Parceria Sul-Sul para o crescimento. Brasília: IPEA/Banco Mundial.

Ben Barka, Habiba. 2011. "Russia's Economic Engagement with Africa". Africa Economic Brief, 11 de maio, v. 2(7).

Beri, Ruchita. 2003. "India's Africa Policy in the Post-Cold War Era: An Assessment". Strategic Analysis, v. 27(2), Apr-Jun.

Bond, Patrick. 2006. Looting Africa. The economics of exploitation. London: Zed Books/Scottsville: University of Kwa-Zulu Natal Press.

Brautigam, Deborah. 2009. The Dragon's Gift: the real story of China in Africa. Oxford: Oxford University Press.

Cardim, Carlos; and Rubens Gama Dias Filho (Orgs.). 2011. A herança africana no Brasil e no Caribe. Brasília: FUNAG.

Cheru, Fantu; and Cyril Obi (Eds.). 2010. The rise of China and India in Africa. London: Zed Books.

Clarke, Duncan. 2010. Africa, a crude continent. The struggle for Africa's oil prize. London: Profile Books. 


\section{Paulo Fagundes Visentini}

Clegg, Jenny. 2009. China's global strategy. Towards a multipolar world. London: Pluto Press.

Coelho, Pedro; and Flávio Saraiva (Orgs.). 2004. Fórum Brasil-África: política, cooperação e comércio. Brasília: IBRI/FUNAG.

D’Ávila, Jerry. Hotel Trópico. 2010. Brazil and the challenge of African decolonization, 1950-1980. Durham/London: Duke University Press.

Donaldson, Robert H.; and Joseph L. Nogee. 2002. The Foreign Policy of Russia: Changing Systems, Enduring Interests. New York: M. E. Sharpe.

Federação Russa. 2008. The Foreign Policy Concept of the Russian Federation. Available at:

<http://archive.kremlin.ru/eng/text/docs/2008/07/204750.shtml>.

Fidan, Hakan; and Bülent Aras. 2010. "The Return of Russia-Africa Relations". Bilig, n. 52: 47-68.

Gadzala, Alex. 2011. "Chinese and Indian entrepreneurs in the East African economies". In India in Africa: Changing Geographies of Power, edited by Emma Mawdsley and Gerard McCann. Cape Town: Pambazuka Press.

Gazibo, Mamoudou; and Roromme Chantal. 2011. Un nouvel ordre mondial made in China? Montréal: Les Presses de l'Université de Montréal.

Gleijeses, Piero. 1999. Conflicting Missions: Havana, Washington, Pretoria. Alberton: Galago Books.

Goldstein, Andrea; Pinaud, Nicolas; Reisen, Helmut; and Xiaobao Chen. 2006. The rise of China and India. What's in it for Africa? Paris: OECD.

Gonçalvez, Jonuel. 2007. Atlântico Sul XXI. África Austral e América do Sul na virada do milênio. São Paulo: UNESP.

Grauvaud, Raphael. 2009. Que fait l'armée française en Afrique? Marseille: Agone.

Guerrero, Dorothy-Grace; and Firoze Manji (Eds.). 2008. China's new role in Africa and the South. A search for a new perspective. Cape Town: Pambazuka Press.

Harneit-Sievers, Axel; Marks, Stephen; and Sanusha Naidu (Eds.). 2010. Chinese and African perspectives on China in Africa. Cape Town: Pambazuka Press. 
Hughes, Arnold (Ed.). 1992. "Marxism's retreat from Africa". The Journal of Communism Studies, v. 8(2), Special Issue. London: Frank Cass \& Company.

Ikome, Francis. 2007. From the Lagos Plan of Action to The New Partnership for Africa's Development. Midrand: Institute for Global Dialogue.

Kapcia, Antoni. 2008. Cuba in Revolution. A history since the fifties. London:

Reaktion Books.

Kornegay, Francis. 2010. “A África do Sul como potência emergente: dilemas especiais e dimensões de segurança". In África do Sul: História, Estado e Sociedade, organizado por Paulo Visentini and Analúcia Danilevicz Pereira. Brasília: FUNAG.

Li, Minqi. 2008. The rise of China and the demise of the capitalist world economy.

New York: Monthly Review Press.

Lima, Maria Regina Soares de; and Monica Hirst (Orgs.). 2009. Brasil, Índia e África do Sul. Desafios e oportunidades para novas parcerias. São Paulo: Paz e Terra.

López, David Gonzáles. 2002. "Relaciones Cuba-África: Marco para um Bojeo Bibliográfico". Estudos Afro-Asiáticos, 24(3).

Manju, Firoze; and Stephen Marks (Eds.). 2007. African perspectives on China in Africa. Cape Town: Pambazuka Press.

Matusevich, Maxim (Ed.). 2007. Africa in Russia, Russia in Africa: Three Centuries of Encounters. Asmara: Africa World Press.

Mawdsley, Emma; and Gerard McCann (Eds.). India in Africa: Changing Geographies of Power. Cape Town: Pambazuka Press.

Mawdsley, Emma. "The rhetorics and rituals of 'South-South' development cooperation: notes on India an Africa". In India in Africa: Changing Geographies of Power, edited by Emma Mawdsley and Gerard McCann. Cape Town: Pambazuka Press.

McCann, Gerard. 2011. "Diaspora, political economy and India's relations with Kenia". In India in Africa: Changing Geographies of Power, edited by Emma Mawdsley and Gerard McCann. Cape Town: Pambazuka Press. Mendonça Jr., Wilson. 2013. Política externa e cooperação técnica. As relações do Brasil com a África durante os anos FHC e Lula da Silva. Brasília: Ed. D'Plácido. 
Mohanty, S. K.; and Sachin Chatuverdi. 2008. "India-Africa economic partnership: trends and prospects". RIS Discussion Papers 134, March.

Moreira, Neiva; and Beatriz Bissio. 1979. Os cubanos na África. São Paulo: Global.

Munanga, Kabengele. 2009. Origens africanas do Brasil contemporâneo. São Paulo: Global.

Oliveira, Ricardo Soares de. 2007. Oil and politics in the Gulf of Guinea. London: Hurst \& Company.

Patman, Robert G. 1990. The Soviet Union in the Horn of Africa: the diplomacy of intervention and disengagement. Cambridge: Cambridge University Press.

Penha, Eli Alves. 2011. Relações Brasil-África e geopolítica do Atlântico Sul. Salvador: Ed. UFBA.

Pere, Garth le (Ed.). 2007. China in Africa: mercantilist predator, or partner in development? Johannesburg: Institute for Global Dialogue/SAIIA.

Power, Marcus; and Ana Cristina Alves (Eds.). 2012. China \& Angola. A marriage of convenience? Cape Town: Pambazuka Press.

Radelet, Steven. 2010. Emerging Africa. How 17 countries are leading the way. Washington: Centre for Global Development.

Rodney, Walter. 1975. Como a Europa subdesenvolveu a África. Lisbon: Seara Nova.

Rodrigues, José Honório. 1964. Brasil e África: outro horizonte. Rio de Janeiro: Civilização Brasileira.

Rotberg, Robert I. (Ed). 2008. China into Africa: Trade, Aid and Influence. Washington: Brookings Institution Press.

Saraiva, José Flávio. 2012. África, parceira do Brasil Atlântico. Belo Horizonte: Fino Traço.

Sautman, Barry; and Yan Hairong. 2006. "Honour and Shame? China's Africa ties in comparative context". In The New Sinosphere: China in Africa, edited by Leni Wild and David Mepham, c. 8, p. 54-61. London: Institute for Public Policy Research.

Schmidt, Elizabeth. 2013. Foreign interventions in Africa. From the Cold War to the War on Terror. Cambridge: Cambridge University Press. 
Shelton, Garth; and Farhana Paruk. 2008. The Forum on China-Africa Cooperation: A Strategic Opportunity. Johannesburg: Institute for Security Studies.

Sheth, V. S. 2008. India-Africa Relations: Emerging Policy and Development Perspectives. Delhi: Academic Excellence.

Shubin, Vladimir. 2008. The hot "cold war". The USSR in Southern Africa. London: Pluto Press/Scottsville: University of KwaZulu-Natal Press.

Sisodia, N. S.; and C. Uday Bhaskar (Eds.). 2005. Emerging India. Security and Foreign Policy Perspectives. New Delhi: IDSA.

Southall, Roger; Henning Melber (Eds.). 2009. A new Scramble for Africa? Imperialism, investment and development. Scottsville: University of KwaZulu-Natal Press.

Power, Michael; Stephan, Harry; Hervey, Angus Fane; and Raymond Steenkamp Fonseca (Eds.). 2006. The scramble for Africa in the 21st century. A view from the South. Cape Town: Renaissance Press.

Strauss, Julia; and Martha Saavedra (Eds.). 2009. China and Africa: emerging patterns in globalization and development. Cambridge: Cambridge University Press.

Taylor, Ian. 2009. China's new role in Africa. Boulder: Lynne Rienner.

Vaz, Alcides Costa (Ed.). 2006. Intermediate States, regional leaders \& security. India, Brazil and South Africa. Brasília: Ed. UnB.

Visentini, Paulo Fagundes; andEquipe CEBRAFRICA. 2013. A África e as Potências Emergentes: Nova Partilha ou Cooperação Sul-Sul? Porto Alegre: Leitura XXI.

Volman, Daniel. 2009. “China, India, Russia and the United States: The Scramble for African Oil and the Militarization of the Continent." Current African Issues 43. Uppsala: Nordiska Afrikainstitut.

Wild, Leni; andDavid Medham. (Eds.). 2006. The New Sinosphere: China in Africa. London: Institute for Public Policy Research.

Yu, George T. 2010. "China's Africa Policy: South-South Unity and Cooperation". In China, The Developing World and The New Global Dynamic, edited by George T. Yu and Lowell Dittmer, c. 7, 129-156. Boulder: Lynne Rienner. 


\section{Paulo Fagundes Visentini}

\section{ABSTRACT}

In the early $21^{\text {st }}$ Century, after the second "lost decade" and rather surprisingly, Africa resumes economic growth, socioeconomic development, relatively political stability and progress in the processes of regional and continental integration. The reason for such inflection results from a combination of both internal and external factors: the stabilization of large African states, the performance of its leaders in the pursuit of political and economic integration (NEPAD and AU) and the increasing presence of emerging powers, especially China, but also the other BRICS countries and other strong developing nations. Based on new capital flows between the semi-periphery and periphery, a phenomenon linked to political-diplomatic and social initiatives from SouthSouth Cooperation occurs and presents significant impacts on the transformation of the international system. Impacts strong enough to make the Western powers, as from the 2008 crisis, begin to seek the reversal of this process.

\section{KEYWORDS}

Africa; Emerging Powers; BRICS; South-South Cooperation.

Received on March 12, 2014. Approved on April 28, 2014.

Translated by Ana Paula Calich, Livi Gerbase, Pedro Alt and Willian Moraes Roberto 



\title{
THE ROLE OF COMMERCIALLY PROVIDED SECURITY IN AFRICA'S PATRIMONIAL SECURITY COMPLEX
}

\author{
Christopher Kinsey ${ }^{1}$, Andreas Krieg ${ }^{2}$
}

\section{Introduction}

Applying Western liberal models of civil-security sector relations to the highly complex and factionalized security sector on the African continent is difficult. Unlike the security sector in Western liberal states whose control is widely monopolized by the institutions of the state and society ${ }^{3}$, the security sector in Africa has never been structured around the concept of security as a public good provided by the state on behalf of or for the protection of a societal public sphere as a whole. On a continent where ethnic, tribal or religious groups have been assigned to artificial territorial entities by colonial powers, the Western notion of an integral nation state built around a public consciousness of togetherness has been widely alien to most of the African states and societies ${ }^{4}$. Consequently, post-colonial states and its civilian leaderships have rarely created a security sector, which is inclusive, representative of domestic social, ethnic, religious or tribal fault lines and undisputed in regulating violence. Instead, African security sectors, whether public or private, have been built

\footnotetext{
${ }^{1}$ Professor of the Department of War and Defence Studies, King's College, London. E-mail: ckinsey.jscsc@defenceacademy.mod.uk.

${ }^{2}$ Department of War and Defence Studies, King's College, London. E-mail: andreas.krieg@kcl.ac.uk.

${ }^{3}$ Elke Krahmann, States, Citizens and the Privatization of Security (Cambridge: Cambridge University Press, 2010), 11.

4 See Christopher Clapham, "African Security Systems: Privatization and the Scope for Mercenary Activity," in The Privatization of Security in Africa, eds. Greg Mills and John Stremlau, 23-46 (Johannesburg: South African Institute of International Affairs, 1999), 25.
} 
around patrimonial networks that by controlling the provision of security ensured that security is provided as an exclusive private good benefitting those elites embedded in such networks.

With the concept of public security generally absent in Africa and a factionalized security sector of both state and non-state actors delivering security exclusively to certain groups affiliated with patrimonial elites, this paper examines the role of commercial providers of security within African security sectors. In factionalized security sectors with limited territorial reach, the state unable or unwilling to provide security as a public good within its boundaries has long lost its monopoly to control violence. It is against this backdrop that this paper asks the question to what extent commercial providers of security in Africa add another dimension to an already complex non-public security sector dominated by de-publicized statutory and non-statutory security providers. Thereby, this paper focuses on the degree to which commercial providers of security are embedded into patrimonial networks catering for exclusive private security interests of certain elites. Focusing on the issue of the private or public nature of commercially provided security in Africa through the prism of normative theory, this paper neither intends to make a moral value judgment about the legitimacy of commercially provided security in Africa nor intends to relativize the private patrimonial nature of commercially provided security as a phenomenon inherent in African civilsecurity sector relations. This paper rather tries to lay an exploratory foundation for the understanding of the interests driving commercial providers of security in Africa.

This paper starts by establishing the theoretical framework that will be used to define the public and private nature of security. We will then outline the particular civil-security sector relations in Africa that shape the private and public nature of African security. Based on the Angolan commercial market for security, we will subsequently analyze to what extent commercial providers of security are embedded into already existing patrimonial power networks in African states. 


\section{Christopher Kinsey and Andreas Krieg}

\section{Conceptualizing the Nature of Security}

The concept of security as either a public or private good can be approached from various angles. In reference to the alleged commoditization of security, in particular the private and public nature of security has been defined on basis of economic public good theory ${ }^{5}$. Public good theory assesses the nature of a good based on excludability and rivalry in order to determine whether it ought to be provided by a private or a public provider ${ }^{6}$. To that end, public good theory can make a contribution to understanding the commoditization of security, however, it fails to grasp the inherent socio-political connotation of the terms public and private. Therefore, when setting out to conceptualize the nature of security one ought to take a more liberal theoretical approach to security, instead of establishing the assessment of the private or public nature of security on the question of who provides it but more importantly who benefits from it. The relevance of the question about the private and public nature of security arises from a widely normative debate in political science and international relations literature ${ }^{7}$. The literature tries to assess the legitimacy of publicly and privately provided security in an era of increased non-state actor involvement in local, national and global security sectors. Hence, as the legitimacy of security is often linked to the state's normative prerogative to monopolize the control as well as authority over and sometimes even ownership of security, the debate about the public and private nature of security lies at the heart of the normative effort to delineate the legitimacy of security. In this respect, the conceptualization of the nature of security ought to be founded on a reference to

5 Elke Krahmann, "Security: Collective Good or Commodity?" European Journal of International Relations No. 14 (2008): 379-404.

${ }^{6}$ Inge Kaul, Isabelle Grunberg and Marc A. Stern, "Defining Global Public Goods," in Global Public Goods: International Cooperation in the 21st Century, eds. Inge Kaul, Isabelle Grunberg and Marc A. Stern, 2-19 (New York: Oxford University Press, 1999), 3.

${ }^{7}$ See Mary Kaldor, New and Old Wars: Organized Violence in a Global Era, 1st ed. (Cambridge: Stanford University Press, 1999); Krahmann, "Security: Collective Good or Commodity?"; Elke Krahmann, "Private Security Companies and the State Monopoly on Violence: A Case of Norm Change?" PRIF Reports No. 88 (2009); Anna Leander, "Conditional Legitimacy Reinterpreted Monopolies: Globalisation and the Evolving State Monopoly on Legitimate Violence" (Paper, ISA, 2002); Herbert Wulf, "The Bumpy Road to Re-Establishing a Monopoly of Violence" (Paper, LSE, 2005); Alyson Bailes, Ulrich Schneckener and Herbert Wulf, "Revisiting the State Monopoly on the Legitimate Use of Force," DCAF Policy Papers No. 24 (2007): 19-26; van Creveld, The Transformation of War (New York: Simon \& Schuster, 1991). 
liberal theory, such as the liberal Social Contract and the thereof arising Huntingtonian theorization of civil-security sector relations.

Conceptually the terms public and private can be traced back to the Ancient Greek dichotomy between the oikos, meaning 'house' or 'household', and the polis, namely the polity ${ }^{8}$. Etymologically, the terms public and private are derivates of the Latin poplicus, meaning 'of the people', and privatus, meaning "withdrawn from public life"9. The public sphere then describes a communal sphere concerned with the public interests of all individuals within an association. In contrast, the private sphere is concerned with the particularistic interests of individuals and households withdrawn from the interests of the community at large. Therefore, the prerequisite for a public and private sphere to emerge is the existence of a community. Through the establishment of a central regulatory authority, this community protects its public interests and the private interests of individuals who are members of this community.

Liberal Social Contract theory provides the theoretical framework to conceptualize the relationship between the individual, the society and the state. According to Hobbes, mankind is born into a state of nature in which the individual is left exposed to the perils of anarchy in absence of a central regulatory authority ${ }^{10}$. It is the individual's desire to enhance its private security, defined by Locke as the individual's desire for protection of its family's and clan's life, liberty and estate ${ }^{11}$, that leads the individual to associate with other individuals to form a larger association for the mutual protection of the interests of all those constituting the association. The individual's desire for private particularistic security lays the foundation for the formation of a state through a social contract with the purpose to ensure the mutual security of all members of a society ${ }^{12}$. Thus, while the individual in the anarchic state of nature is concerned with providing private security for itself, its family or clan, the state ought to provide public security inclusively for all members of the

\footnotetext{
${ }^{8}$ J. Roy, "'Polis' and 'Oikos' in Classical Athens," Greece \& Rome Vol. 46, No. 1 (April 1999): 1.

${ }^{9}$ See Oxford Dictionary.

${ }^{10}$ Thomas Hobbes, Leviathan (Sioux Falls: Nuvision Publications, 2004), 74.

${ }^{11}$ John Locke, The Two Treatises of Government. Essay Two (Indianapolis: Hackett Publishing Company, 1980), Ch. IX, § 123.

12 Hobbes, Leviathan, 99.
} 


\section{Christopher Kinsey and Andreas Krieg}

society it serves. With the state's monopolization of the legitimate authority over violence, the state withdraws the individual's private right to resort to violence in the state of nature in exchange for the promise to protect the individual in a public state of security. Thus, the state's monopolization of the legitimate authority over violence provides the foundation for the publicisation of security ${ }^{13}$. Thereby, the legitimacy of a state and its monopoly on the legitimate authority over violence depends on its ability to provide public security inclusively for all members of society from both internal and external threats $^{14}$. Good governance in this respect is characterized by the degree of public inclusiveness with which the state is able or willing to protect the interests of the public. Whereas arguably no state has ever achieved full inclusiveness in the provision of public security, Western liberal states have come close to providing security inclusively for every individual, group or minority within their societies ${ }^{15}$.

In order for the state to be able to provide public security it relies on the domestic security sector. Traditionally the state's domestic security sector ought to be regulated by the state to ensure that all state-owned and nonstatutory forces providing security do so inclusively without violating the public security of all individuals within its boundaries. According to Huntington, particularly the public security sector, namely the military, law enforcement and intelligence services, is conceived as a public servant of state and society and ought to be controlled by the public ${ }^{16}$. To that end, Huntington ascribes the statutory forces a professional raison d'être, which revolves around the realization that it has to use its skills according to a set of professional values to protect public security interests above private individual, group or partisan politics ${ }^{17}$. In fact, the public security sector ought to be politically disconnected from the civilian leadership allowing for the public security sector

${ }^{13}$ Clapham, "African Security Systems," 23.

${ }^{14}$ Herbert Howe, Ambiguous Order: Military Forces in African States (New York: Lynne Rienner, 2004), 9.

15 Clapham, "African Security Systems," 25.

16 Samuel P. Huntington, The Soldier and the State: The Theory and Politics of Civil-Military Relations (London: Harvard University Press, 2003).

17 Mathurin C. Houngnikpo, Guarding the Guardians: Civil-Military Relations and Democratic Governance in Africa (London: Ashgate, 2010), 76. 
to not only serve a particular government but to serve the public at large. The required clear division between the civilian sphere and the public security sector ought to ensure that the latter remains a servant of society and state fully accountable to societal public scrutiny ${ }^{18}$. Therefore, the conceptualization of civil-security sector relations in liberal theory rests on the assumption that the public security sector is constitutionally integrated into the organization of a liberal state, which rules with the public consent of a liberal society. Traditionally, the absence of a liberal dimension in one of the trinity's components ${ }^{19}$, namely society, state or security sector, appears to obstruct the proper provision of security as a public service in the inclusive interests of all individuals within a society.

In sum, in order to conceptualize the public and private nature of security one has to understand whose security interests are served. From a liberal theoretical point of view, private security describes security that is provided not inclusively on behalf of a societal public, but exclusively for the protection of private individual, group or partisan lives, liberties or estates. It follows that public security is concerned with the inclusive protection of the lives, liberties and estates of a public, namely an association of individuals managed by the regulatory authority of a state acting on behalf and with the consent of this association.

\section{The Nature of Security in Africa}

Trying to provide a holistic account of the nature of security on the African continent will inevitably result in generalizations. Some African states do better than others in creating inclusive public security sectors. Also, the status quo of civil-security sector relations can change quickly on a continent, which has a long history of political, social, economic, or ethnic unrest ${ }^{20}$. Nonetheless,

\footnotetext{
${ }^{18}$ Huntington, The Soldier and the State, 81.

19 According to liberal theory, the provision of security ought to be founded on a civil-security sector complex consisting of liberal society, liberal state and its agent the security sector. This civil-security sector complex is referred to by Clausewitz as the 'trinity', which guarantees that particularly in war security is provided as a public good benefiting society's security interests. See Carl von Clausewitz, Vom Kriege. Book 1 (Berlin: Ferdinand Dümmler, 1832-34) Ch. 1, § 28.

${ }^{20}$ Howe, Ambiguous Order, 2.
} 


\section{Christopher Kinsey and Andreas Krieg}

African states all share a common legacy that until today shapes the way African societies relate to their states and security sectors: a colonial history creating the geographic, ethnic and political reality on the continent. Most African states did not emerge as a result of a genuine free will of individuals with a common history, language, religion or ethnicity to form a public association, but are the result of an external carve-up of the continent for mere administrative purposes by colonial powers ${ }^{21}$. As a consequence, many African states today are highly pluralistic entities in terms of their citizen's ethnic, religious, lingual or tribal affiliations that often take precedence over a sense of national belonging ${ }^{22}$. The individual's feeling of affiliation with a public entity is therefore commonly undermined by pervasive forms of subnational nonpublic affiliations. To some extent this stands in stark contrast to the individual's integration into its community and sense of serving its community in Africa of pre-colonial times. Although not being part of a public liberal society administered by a state, Africans in the pre-colonial era demonstrated strong affiliations with their more homogenous communities willing to take up arms to provide security in defence of the public ${ }^{23,24}$. Thus, as feelings of national affiliation have been traditionally alien to African societies, those states that emerged from the colonial era were confronted with the task to cultivate a sense of public belonging beyond subnational identities so as to create realms of inclusive public security for all individuals within their boundaries. However, security sectors in Africa have rarely been public in nature for both societies and states have lacked a sense of public cohesiveness and mutual responsibility towards fellow individuals within the public association. Subsequently,

The management of security by at least a substantial number of African states is in practice essentially 'private', in that such security as exists is primarily concerned to protect the lives, power and access to wealth of specific groups and individuals

${ }^{21}$ Clapham, “African Security Systems," 25.

${ }^{22}$ Howe, Ambiguous Order, 12.

${ }^{23}$ Ramkrishna Mukherjee, Uganda, A Historical Accident?, $10 \mathrm{ff}$.

${ }^{24}$ Robert E. Edgerton, Africa's Armies: From Honour to Infamy. (Boulder, CO: Westview, 2002), 17. 
who control the state, and is not substantially different from the security provided, say, by a warlord who is not formally recognised as representing a state. ${ }^{25}$

Both state and non-state security providers have done little to provide security inclusively as a public good in Africa. In the following sections we will discuss how state and non-state actors shape the nature of security in Africa.

\section{State Actors Providing Security in Africa}

As discussed in the previous section, the liberal ideal of civil-security sector relations revolves around civilian control of the security sector as well as the public state-owned security sector's ambition to serve civil-society and state to provide security as a public good. In Africa, the public security sector consists of statutory forces such as the military, law enforcement or intelligence services. In many cases the public security sector is a remnant of the colonial era, not providing security inclusively for all individuals within the public sphere but exclusively for certain groups or regimes ${ }^{26}$. Instead of being a true servant of the public's desire for uncompromised protection from domestic and external security threats, in the decades following independence African public security sectors have increasingly become servants of ruling elites' particularistic private partisan interests. African public security sectors' failure to assume the role of providing security as a public good on behalf of society at large can be explained by two instances that have triggered African public security sectors to become politicised, as opposed to publicised, guardians of partisan private interests. In the first instance, a strong state tries to mitigate the influence of the security sector and in the second instance, a strong security sector tries to mitigate the influence of the state.

Due to the fact that the public security sector commonly constitutes the most powerful dimension within a state, autocratic African regimes that assumed power after independence were often scared that the public security sector might protect the interests of the public rather than the regime's particularistic private interests. Therefore, many post-colonial African regimes tried to reshape the domestic public security sector by investing into

\footnotetext{
${ }^{25}$ Clapham, "African Security Systems," 24.

${ }^{26}$ Samuel Decalo, Coups and Army Rule in Africa, (New Haven, CT: Yale University Press, 1976), 14-15.
} 


\section{Christopher Kinsey and Andreas Krieg}

commissarism $^{27}$, namely the attempt to control the public security sector through the establishment of parallel competing security forces or various forms of ethnic, tribal or partisan favouritism. First, most regimes in post-colonial Africa have tried to secure their own private patrimonial interests against popular uprisings or internal security sector mutiny by raising parallel private security forces as a counterweight to existing public security forces. Rather than actually providing security as a public good, such parallel security forces provide security as a private good for particular elites close to the regime. Examples are former Ghanaian President Nkrumah's Own Guard Regiment, former Congolese President Mobutu's Division Spéciale Présidentielle or former Rwandan President Habyarimana's Presidential Guard and Interahamwe militia $^{28}$. African regimes have also created powerful intelligence services, which are often ethnically, religiously or tribally affiliated with the ruling elites to ensure that public security forces were kept in check protecting the private interests of a patrimonial ruling elite rather than the interests of the public ${ }^{29}$. Second, authoritarian regimes in Africa have traditionally made efforts to separate the security sector from society by forms of ethnic, tribal or partisan favouritism. Based on a practice born in the colonial era, regimes have tried to establish boundaries between the public security sector and the public they ought to protect ${ }^{30}$. They have done so by filling key positions within the public security sector's leadership with individuals pledging allegiance to the state not based on nationality but based on ethnicity, religion, tribe, family or ideology ${ }^{31}$. As a result, the state-owned security sector provides security as a private good for the ruling elite sometimes at the expense of minority groups in the public that do not affiliate with the private group interests of the regime. The former

${ }^{27}$ Kenneth M. Pollack. "The Arab Militaries - The Double Edged Sword," in The Arab Awakening: America and the Transformation of the Middle East, ed. Kenneth M. Pollack (Washington, DC: Brookings, 2011), 59.

${ }^{28}$ Howe, Ambiguous Order, 44.

${ }^{29}$ Zoltan Barany, The Soldier and the changing State - Building Democratic Armies in Africa, Asia, Europe, and the Americas (Princeton, NJ: Princeton UP, 2012), 284.

${ }^{30}$ Claude E. Welsh. "Emerging Patterns of Civil Military Relations in Africa: Radical Coups d'état and Political Stability," in African Security Issues: Sovereignty, Stability and Solidarity, ed. Bruce E. Arlinghaus (Boulder, CO: Westview Press, 1984), 129.

${ }^{31}$ Augustine J. Kposowa and J. Craig Jenkins, “The Structural Sources of Military Coups in Postcolonial Africa, 1957-1984," American Journal of Sociology Vol. 99 No. 1 (1993): 130. 
Ghanaian President Nkrumah did not only enforce a recruitment policy based on ethnic favouritism, but also ensured that individuals in the public security sector were members of his Convention People's Party achieving a degree of non-public ideological alignment ${ }^{32}$.

The move towards privatization of the public security sector in Africa in the years following independence has created highly factionalized security sectors, which have accumulated wealth and power through privileged access to states that have been corrupted by particular partisan groups and interests. Particularly individuals in key positions of the public security sector have accumulated private wealth through public patronage and compradorial business connections ${ }^{33}$. Decades of private enrichment, control of key sectors of the economy and various forms of favouritism have allowed many public security sectors in Africa to consolidate their domestic power. As a consequence, much of the public security sector acts now as the guardian of certain regimes' private interests and privileged position ${ }^{34}$. State owned security providers in some African countries have grown so strong so as to become a praetorian force obstructing the liberalization of the state as well as the professionalization of the state's security forces. Weak states unable to cope with various domestic issues such as economic mismanagement, weak societal integration or ethnic and class conflict, were targeted by the state's owned security forces under the false messianic pretence to salvage an infected country from the abyss of political incompetence ${ }^{35}$. Liberalizing states in particular have become vulnerable to the praetorian intervention by public security sectors, which are anxious about losing their privileged position. As economic stability and public order are essential for the legitimacy of a state, regardless of whether liberal or not, the failure of Africa's liberalizing states to provide these public goods often results in the removal of liberalizing regimes by the public security sector $^{36}$.

\footnotetext{
32 Barany, The Soldier and the changing State, 284.

${ }^{33}$ Robin Luckham, “The Military, Militarization and Democratization in Africa: A Survey of Literature and Issues," African Studies Review Vol. 37 No. 2 (1994): 38.

${ }^{34}$ Mathurinn C. Houngnikpo, Guarding the Guardians: Civil-Military Relations and Democratic Governance in Africa (London: Ashgate, 2010), 60.

35 Ibid, 99.

${ }^{36}$ John F. Clark, “The Decline of the African Military Coup," Journal of Democracy Vol. 18 No. 3 (2007): 154.
} 
Signs of domestic political or economic instability become the pretext for the consolidation of private security at the expense of public security.

Thus, looking back at almost half a century of post-colonial independence in Africa, few states were able or willing to create a public stateowned security sector providing security as an inclusive public good. In fact, most public security sectors in Africa have de facto become privatized and depublicized as they provide security exclusively as a private good for certain ethnic, religious, tribal or partisan factions. Often, security as a private good does not only fail to generate inclusive benefits to certain individuals and groups but even comes at the expense of those marginalized. That is to say, private partisan security becomes a zero-sum game whereby the increased security of ruling elites creates growing insecurity for those excluded as the latter are arrested, detained, tortured or killed without any public protection ${ }^{37}$.

\section{Non-State Actors Providing Security in Africa}

In face of the African state's common failure to assume the role of the public servant relying on its state-owned public security sector to provide security inclusively on its territory, alternative private security sectors have emerged. Resorting to the private use of force has become an alternative means for marginalized or terrorized individuals to provide security in anarchical failed states that either lost their ability or their willingness to provide public security inclusively to all individuals within their territory ${ }^{38}$. As many African states have lost their legitimacy as public actors or their monopoly on the control over violence, private actors have assumed the role to provide security as a private good for all those left unprotected by corrupted, politicized public security sectors ${ }^{39}$. Due to the fact that the African state has widely disregarded its social contractarian duty to provide public security inclusively, many individuals and groups have annulled the covenant between society and state returning to the provision of private security in a quasi anarchical state of nature. Kieh

\footnotetext{
${ }^{37}$ Edgerton, Africa's Armies, 3.

${ }^{38}$ George Klay Kieh and Pita Ogaba Agbese Kieh. "Introduction: The Military Albatross and Politics in Africa," in The Military and Politics in Africa, eds. George Klay Kieh and Pita Ogaba Agbese Kieh. (London: Ashgate, 2004), 7.

${ }^{39}$ Luckham, The Military, Militarization, 19.
} 
categorizes private providers of security into six different groups that operate in African private security sectors by providing security exclusively as a private good: secessionists, warlords, populist insurgents, vigilants, ethnic militias and mercenaries $^{40}$.

One of the most common private security providers in the highly factionalized African states are secessionist groups, which neglected and marginalized by their respective state try to break away and create their own independent public state ${ }^{41}$. In 1966 controlled by tribes from Northern Nigeria, the Nigerian public security sector turned against members of the Ibo tribes excluding them from the realm of public security. In consequence, members of the Ibo tribe declared their own state of Biafra in 1967 in the Eastern provinces of Nigeria in an attempt to enhance their security ${ }^{42}$. Although providing security as a private good exclusively to members of the Ibo tribe, the newly created Biafran armed forces challenging the politicized Nigerian public security sector, were able to establish a sense of public security in this new state.

Warlordism has become another major source of private security on the African continent. Unlike secessionist groups, warlords do not necessarily want to break away from existing states. Instead, warlords operate transnationally in quasi-states without being constrained in their activities by public security sectors ${ }^{43}$. Warlords are able to create entities of private security by arming family or clan members to protect the warlord's own private interests. The failed state of Somalia presents an interesting case whereby a state unable to provide public security has allowed warlords to organize security as a private $\operatorname{good}^{44}$.

Populist insurgencies led by charismatic leaders based on an inclusive populist agenda are an interesting example of non-state actors potentially providing public security in cases where public security sectors fail to do so. As

${ }^{40}$ See George Klay Kieh, "Military Engagement in Politics in Africa," in The Military and Politics in Africa, eds. George Klay Kieh and Pita Ogaba Agbese Kieh. (London: Ashgate, 2004).

41 Ibid, 47

${ }^{42}$ Edgerton, Africa's Armies, 104-108

${ }^{43}$ Kaldor, New and Old Wars, 97.

44 Christopher Kinsey, Stig Jarle Hansen and George Franklin, "The impact of private security companies on Somalia's governance networks," Cambridge Review of International Affairs, Vol. 22, No. 1 (2009). 


\section{Christopher Kinsey and Andreas Krieg}

grass root movements insurgencies understand that they have to gain legitimacy in the eyes of the public at large. Relying on the public for intelligence, logistics and recruits, the Ugandan National Resistance Army (NRA) invested highly into being perceived as a public force for good in their struggle against Obote's corrupted regime in the early $1980 \mathrm{~s}^{45}$. Providing aid, infrastructure and public protection from the politicized, factionalized public security sector, the NRA as a non-statutory force was able to deliver public security inclusively.

Kieh further identifies vigilants as another group operating in Africa's private security sectors. As ethno-communal or religious groups trying to impose their own norm of 'law and order', vigilants feel excluded from the realm of public security and decide to take up arms to protect their communities in a state of anarchical insecurity ${ }^{46}$. In the same way, also ethnic militias operate as private security providers creating private realms of security for members of particular ethnic groups in response to the post-colonial African state's unwillingness or inability to provide inclusive public security.

Apart from domestic private providers of security, also mercenaries as external private security providers have been involved in Africa's private security sectors. Motivated by private individual profit, mercenaries have a long history in Africa being hired locally or abroad to provide private security for particular regimes or ethnic, religious and partisan groups. Since the end of colonialism mercenaries have taken advantage of the security vacuums in Africa to fight for example for Belgian business interests in Congo and British

45 Maj Charles Kisembo, "The Civil-Military Relations in Countries Emerging From Instabilities in Africa: The Challenge for the Security Sector Reform (SSR)," Joint Services Command and Staff College Defence Research Paper (2006): 15.

${ }^{46}$ Kieh, "Military Engagement in Politics," 49. 
oil interests in Nigeria in the $1960 \mathrm{~s}^{47}$, for the CIA in Angola in the $1970 \mathrm{~s}^{48}$, for Mobutu in Zaire in the $1990 \mathrm{~s}^{49}$ or for Ghaddafi in Libya in $2011^{50}$.

Inter alia motivated by profit seeking and therefore often prematurely tagged with the mercenary label, private commercial providers of security are the most recent phenomenon in Africa's highly diverse security sectors. Unlike mercenaries, contractors working for commercial providers of security commonly referred to as private military and security companies (PMSCs), are not driven by individual profit but are employees of commercial enterprises delivering a diverse range of security services for corporate business profit ${ }^{51}$. Also, unlike mercenaries, PMSCs tend to not involve themselves in political intrigue $^{52}$. Ever since the first modern establishment of commercial providers of security in the late 1960s, Africa had been a core market for commercially provided private security services ${ }^{53}$. It was not, however, until the 1990 s that commercial companies became prominent actors in Africa's private security sectors $^{54}$. The commercialisation of security in the modern era can be traced back to the founding of the British PMSC Watchguard in 1967, which laid the foundation for an expanding commercial security industry in the $1980 \mathrm{~s}^{55}$. Private commercial security in Africa became the subject of public attention only with the military operations conducted by the former South African PMSC

${ }^{47}$ Angela McIntyre and Taya Weiss, "Weak governments in search of strength - Africa's experience of mercenaries and private military companies," in From Mercenaries to Market: The Rise and regulation of private military companies, eds. Simon Chesterman and Chia Lehnardt (Oxford: Oxford University Press, 2009), 68.

48 Abdel-Fatau Musah and J. 'Kayode Fayemi, “Africa in Search of Security: Mercenaries and Conflicts, an Overview," in Mercenaries: an African Security Dilemma, eds. Abdel-Fatau Musah and J. 'Kayode Fayemi (London: Pluto Press, 2000), 23.

49 Khareen Pech, "The Hand of War: Mercenaries in the former Zaire," in Mercenaries: an African Security Dilemma, eds. Abdel-Fatau Musah and J. 'Kayode Fayemi (London: Pluto Press, 2000), 127.

${ }^{50}$ Martin Chulov and David Smith, "Libya: Gaddafi's army of mercenaries face backlash," The Guardian, September 02, 2011.

51 Christopher Kinsey, Corporate Soldiers and International Security: The Rise of Private Military Companies (London: Routledge, 2006), 64.

52 Caroline Holmquist, "Private Security Companies: The Case for Regulation," SIPRI Policy Paper No. 9 (2005): 9.

${ }^{53}$ Kinsey, Corporate Soldiers, 47.

${ }^{54}$ Adedeji Ebo, "Private Actors and the governance of security in West Africa," in Private Military and Security Companies: Ethics, Policies and Civil-Military Relations, eds. Andrew Alexandra, Deane-Peter Baker and Marina Caparini (London: Routledge, 2008), 144.

${ }^{55}$ Kinsey, Corporate Soldiers, 51. 
Executive Outcomes (EO) on behalf of the Angolan and Sierra Leonean government in 1993 and $1995^{56}$. Clapham argues that commercial security providers such as EO although providing military combat support services in a commercial capacity, sometimes can provide security as a public good in absence of a willing or potent public security sector to do $\mathbf{s o}^{57}$. The reason is that private commercial providers of security in Africa, if not employed domestically by certain elites, intervene in conflicts as external third parties with fewer antagonisms towards certain groups within the public. This allows them to potentially provide security more considerately as a public good for all individuals within the operational environment - even if public security is just a secondary outcome to achieving tasks with primarily private benefits.

This section has demonstrated that the liberal ideal of the state monopolizing the authority over violence by agreeing to provide public security in exchange for the individual's renunciation of the unauthorized private use of violence, is still some way off on the African continent. For most public security sectors fail to provide inclusive public security, private security sectors have been established to provide security as both public and private goods. The nature of security in Africa is thereby determined by a variety of state and nonstate actors that mostly provide security on factionalist terms favouring private interests of ethnic, religious, tribal or partisan groups while often failing to provide security as a truly public good.

\section{The Nature of Commercial Security in Angola}

Eleven years after the end of the civil war Angola finds itself in a state of rapid economic growth and steady reconstruction emerging as a regional power in Southern Africa. Mostly fuelled by expansive hydrocarbon revenue, Angola's economy has not just recovered from decades of civil war but it has also laid the foundation for Angola's image as a boom country amid regional economic and political decay. Extractive industry producing oil and gas in the West and diamonds in the East of the country has been the motor for economic growth

\footnotetext{
${ }^{56}$ Eeben Barlow. Executive Outcomes: Against All Odds (Johannesburg: Galago Publishing, 2008), 295.
}

${ }^{57}$ Clapham, "African Security Systems," 44. 
and growing prosperity particularly for Angola's urban society. As a consequence, the protection of this core industry's operations has become a priority for national security. Unable to provide for the security of extractive industries alone, public security sector services have been supplemented by commercially provided security services since the early 2000s. Today, Angola has one of the largest and highly developed indigenous commercial security sectors in Africa, which is closely tied to the country's mineral resource wealth $^{58}$. Therefore, this section will focus upon Angola as a case study on basis of which to examine the nature of commercially provided security on the African continent. As a country shaped by an only recently concluded civil war, various social and economic sources for domestic instability as well as extensive foreign investment into its mineral resource wealth, Angola presents a predestined case to explore to what extent commercially provided security in Africa is either public or private in nature.

Before analyzing the commercial market for security in Angola one has to first understand the socio-political reality of the country and its impact on the provision of security as either a public or private good. After its release into independence from Portugal in 1975, a civil war erupted between three liberation movements; the FNLA, the MPLA and UNITA. Supported by different social and ideological bases, particularly the latter two movements grew into important political players in post-independence Angola. The Movimento Popular de Libertação de Angola (MPLA) was founded by the leftwing educated urban elite of Portugal-phile assimilados in Angola's capital Luanda and followed a Marxist ideology. The União Nacional para a Independência Total de Angola (UNITA) was a liberation movement without a clear ideological orientation but a strong rural African base comprising individuals from mostly the Ovimbundu and Bakongo tribes in the North and East of the country ${ }^{59}$. Despite short intervals of instable peace, these two movements, after partially absorbing members of the FNLA, fought each other

58 Ulrike Joras and Adrian Schuster, "Private Security Companies and Local Populations: An Exploratory Study of Afghanistan and Angola," Swiss Peace Working Paper No.1 (2008): 45.

59 Sean Cleary, "Angola: A case study of private military involvement," in Peace, Profit or Plunder? The Privatization of Security in War Torn African Societies, eds. Jakkie Cilliers and Peggy Mason (Johannesburg: Institute for Security Studies, 1999), 143. 


\section{Christopher Kinsey and Andreas Krieg}

in a brutal civil war lasting for almost three decades dividing the country into two spheres of influence, whereby the Western coastal areas were controlled by the MPLA and the Eastern rural areas by UNITA. When the civil war came finally to an end in 2002, the MPLA under the leadership of President Dos Santos emerged victoriously assuming control of the entire country and supervising the disarmament of UNITA fighters. Nonetheless, Angola remains until this day one of the most militarized countries in Africa, defined not just but an extensive circulation of fire arms among the civilian population but also one of the largest public security sectors on the continent ${ }^{60}$. At the heart of civil-security sector relations stands a closely knit patrimonial network surrounding President Dos Santos, which similar to other African states, has developed into a shadow administration controlling all aspects of economic, political and security affairs in the country. In executing control over Angolan economic, political and security affairs, similar to other regimes in Africa, Dos Santos's administration has primarily not catered for the interests of the public but for its own interests. In order to protect his patrimonial system, Dos Santos has engaged into extensive coup-proofing over the past decades by creating a diversified public security sector, which consists of the National Police, the Angolan Armed Forces (FAA), the Military Police, the paramilitary Rapid Intervention Police (known as the 'Black Ninjas'), the Presidential Guard and the Organization of Civil Defence ${ }^{61}$. Particularly, the Presidential Guard and the Rapid Intervention Police are recruited on basis of tribal affiliation ensuring that both entities do not establish bonds with the public in the MPLA's core areas around Angola's capital Luanda. Effectively, Dos Santos has created a dual security sector directly controlled by him and the MPLA acting as a counterweight to the FAA and regular national police ${ }^{62}$. While the diversification of the public security sector has obstructed plotting against the regime and kept certain forces within the FAA in check by creating a buffer between potential plotters and the MPLA's regime, it has rendered the

${ }^{60}$ Alex Vines and Markus Weimer, "Assessing Risks to Stability," Report to the CSIS Africa Program, (June 2011): 13

${ }^{61}$ Joras and Schuster, "Private Security Companies and Local Populations," 39.

${ }^{62}$ Paula Cristina Roque, "Angola: Parallel Governments, Oil and Neopatrimonial System Reproduction," Institute for Security Studies Situation Report, June 06, 2011, 4. 
provision of public security widely ineffective ${ }^{63}$. Similar to developments in public security sectors in other African countries discussed in the previous section, the failure of the public security sector in Angola to provide public security in some areas of the country has caused civilians to arm themselves to provide for their own security. It is against this backdrop that one has to approach the analysis of the nature of the commercial security sector in Angola.

The history of commercially provided security in Angola dates back to the employment of the former South African PMSC Executive Outcomes (EO) by the MPLA government between 1993 and 1995. Impressed by the operational effectiveness of EO in liberating UNITA held territories, Angolan military leaders created their own PMSC, Sociedade de Telecomunicações, Segurança e Serviços (TeleService), and laid the foundation for an indigenous Angolan market for commercial security ${ }^{64}$. Among the more than 300 indigenous companies operating in Angola today, TeleService and Alpha 5 remain the biggest players on a market characterized by high market concentration $^{65}$. Unlike other commercial security markets even in Western countries, Angola has one of the most regulated markets in the world. Through the Law on Private Security Companies (19/92) and Diamond Law (16\&17/94), the Angolan state has reinforced its monopoly on the legitimate authority over violence by controlling the market entry and service levels of commercial security companies ${ }^{66}$. In essence, these state-enforced market regulations aim at first maintaining state control over commercially provided security and second demarcating the scope of private and public security. According to the definition laid down in Law (19/92) and (16\&17/94), the protection of private assets of extractive industries is not a public good provided for by the Angolan public security sector but a private good that ought to be provided by private commercial providers of security ${ }^{67}$. Today, Angolan PMSCs predominately serve this purpose of catering for the security of extractive industry operations in the diamond areas of Lunda Norte \& Sul as well as in the oil rich areas along

${ }^{63}$ Wines and Weimer, “Assessing Risks to Stability," 15.

${ }^{64}$ Cleary, "Angola: A case study," 147.

65 Joras and Schuster, "Private Security Companies and Local Populations," 46.

${ }^{66}$ Lei Sobre as Empresas Privadas de Segurança, Lei no. 19/92 de 31 de Julho (1992).

${ }^{67}$ Joras and Schuster, "Private Security Companies and Local Populations," 41. 
the coast. In so doing, it seems at first sight as if commercial providers of security in Angola operate detached from the public security sector merely protecting private commercial interests of extractive industries. However, when looking behind the façade of Angola's commercial security and extractive industry, one finds a complex network of different private and public actors who directly or indirectly control the provision of security in the country.

Similar to other African countries, Angola has a public state-owned security sector that has difficulty providing security as an inclusive public good for all individuals within the country. The highly diverse public security sector has de facto become privatized and de-publicized as the public security sector predominately serves the exclusive security interests of certain political and military elites close to President Dos Santos. While the Angolan public security sector does not deliberately marginalize certain groups based on their political, tribal, religious or ethnic affiliation, it has been closely tied into a complex network of MPLA, industry and military representatives serving the sole purpose of providing security as a private good for those elites. The commercial security sector in Angola is embedded into this complex elitist network as well. This elitist network is presided over by a presidential clique that de Oliveira dubs the 'futungo' and that comprises non-elected individuals with close direct ties to President Dos Santos ${ }^{68}$. The futungo holds key positions within Angolan extractive industry, the military, the MPLA and ultimately in the commercial security sector. The most important asset of the futungo is the giant national petroleum company Sonangol, which supplies the presidential patronage network with oil money through export revenues and foreign debts run against future oil production ${ }^{69}$. Accounting for $90 \%$ of government revenues in the $1990 \mathrm{~s}$, Sonangol, which is controlled by key players in the futungo, allowed the presidential clique to misappropriate public money that could be used to erect a parallel state structure more powerful than actual public state institutions. Thus, the futungo's private enrichment at the expense of the Angolan public mineral resource wealth depends on the security of extractive industry

${ }^{68}$ Ricardo Soares de Oliveira, "Business success, Angola-style: postcolonial politics and the rise and rise of Sonangol," The Journal of Modern African Studies, Vol. 45 (December 2007): 606.

${ }^{69}$ Ibid. 
operations, which is guaranteed not just by the public security sector but increasingly by the private commercial security sector. That is to say that commercial security providers in Angola do not merely provide security for private mineral extraction companies but also indirectly for the private interests of the regime around President Dos Santos ${ }^{70}$.

Apart from generating exclusive revenues via mineral extraction companies, political, military and business elites affiliated with the futungo have also discovered the commercial market for security as a lucrative means to create income ${ }^{71}$. The most influential PMSCs in Angola, among them TeleService and Alpha 5, are wholly or partially owned by elites close to the presidential clique ${ }^{72}$. Embedded in the patrimonial network tied to the private interests of Dos Santos, Angolan commercial providers of security generate further economic and political power for the president's parallel state structure. In this respect, the ban of foreign commercial providers of security under Law 19/92 cannot be understood as merely a means to enhance public state control of the market but has to be perceived as a means to enhance the regime's private control of the market for its own benefit ${ }^{73}$. By revoking the operating license of foreign commercial providers of security, the futungo has ensured that its share of Angola's market for commercial security has increased leading to a further concentration of political and financial power in the private hands of the presidential elite ${ }^{74}$. The elitist control over the market for commercially provided security has a strong impact on the political power of certain elites who are able to increase their ability to provide security not as a public good but as a private good. As members of the futungo hold key positions in both the public and commercial Angolan security sector, the regime has increased its leverage in certain areas, especially in the diamond rich East of the country, where national police and the FAA have difficulty providing security. In these

${ }^{70}$ Paul Cammack, David Pool and William Tordoff, Third World Politics: A Comparative Introduction (New York: Macmillan, 1994), 91.

${ }^{71}$ Alex Vines, Nick Shaxson and Lisa Rimli, "Drivers of Change Angola," Chatham House Position Paper No. 1 (2005).

72 Herbert Howe, “African Private Security," Conflict Trends (June 2000): 23.

${ }^{73}$ Patrick Cullen, "Keeping the New Dog of War on a tight leash: Assessing means of accountability for Private Military Companies," Conflict Trends (June 2000): 39.

74 Joras and Schuster, "Private Security Companies and Local Populations," 50. 
parts of Angola, the commercial security sector acting as a far better equipped and trained appendix of the public security sector does not merely provide private security for extractive industry operations but also generates spill-overs to the public sphere by de facto assuming law enforcement functions ${ }^{75}$. By arresting, detaining and flogging illegal miners with impunity, Angolan PMSCs operate on behalf of the private interests of those elites who run the parallel state and benefit from the extraction of certain mineral resources while exercising control in the public sphere. Nonetheless, although mimicking the posture of a public security provider and acting under the authority of the regime, security provided by PMSCs in mineral resource extraction areas is private in nature ${ }^{76}$. Marginalizing the public security sector, commercial providers of security in Angola contribute to the establishment of security in the public sphere, which only benefits certain political, military and business elites $^{77}$. In 2007 Human Rights Watch reported an incident whereby commercial providers of security were used alongside public security sector forces to evict poor residents from an area that was designated by the regime for redevelopment. According to $\mathrm{HRW}$ PMSC employees made use of heavy fire arms to force poor residents from their land while being supported rather than constrained by national police and Rapid Intervention Police ${ }^{78}$. This instance demonstrates to what extent commercial providers of security help the regime in Luanda to further its private commercial interests sometimes at the expense of public security.

Circumventing public accountability, PMSCs function as private reserve armies for the futungo assisting the personal non-public institutional nature of Dos Santos' regime ${ }^{79}$. Thereby, commercially provided security has become an alternative way for the presidential clique to foster an emancipation of security providers from public civil-societal control strengthening the ability

75 Rafael Marques de Morais, "Private security companies and a parallel State in Angola," Africa Files (December 2007).

${ }^{76}$ Joras and Schuster, "Private Security Companies and Local Populations," 54.

77 Morais, "Private Security Companies and a parallel State."

78 "They Pushed Down the Houses: Forced Evictions and Insecure Land Tenure for Luanda's Urban Poor." Human Rights Watch Report Vol. 19, No.7 (2007): 27.

${ }^{79}$ Joras and Schuster, "Private Security Companies and Local Populations," 51. 
of the regime to provide security for its own private interests. In a country such as Angola, where key positions in the public security sector are already being held by individuals close to the President, commercial security providers contribute to an increased de-publicization of security transforming the nature of security in Angola evermore into a private good. As a consequence, security in Angola mainly serves a patrimonial network around the President that has previously invested into the creation of a parallel private state structure constituting the actual power-related centre of gravity in Angola.

\section{Conclusion}

As African states widely fail to provide public security inclusively for all individuals within their territories, Africa has given birth to one of the fastest growing markets for commercially provided security in the world. While in Western liberal states the commercialization of security constitutes a major paradigm shift, the commercialization of security in Africa follows an already common pattern.

As this paper has demonstrated, security in Africa has rarely been a truly public good inclusively provided by the state on behalf of its society for all individuals within their territory. Much more, African states have developed into parallel elitist entities not catering for the public needs of all its citizens but serving only those tied to the patrimonial network of the regime through sectarian or commercial affiliation. In the same way security is commonly not been provided as an inclusive public good for the benefit of all, but as a private good benefiting only particular elites within a complex of patrimony. The nonpublic, private nature of security in Africa relates to two factors: first, it only benefits selective groups within the public and often comes at the expense of other groups, and second, it is controlled and maintained by sectarian elites tied into patrimonial networks. That is to say, regardless of whether security is provided by state actors such as the military, police or secret services or by nonstate actors such as warlords, rebel movements or militant religious fractions, security on the African continent rarely benefits the security needs of public societies as communities bound by territorial boundaries. Commercial providers of security appear to fall into the same pattern. Although privately owned and striving after business profit, commercial providers of security as private non- 
statutory actors do not necessarily sell their services freely on the public market for security. Instead, the commercial security sector functions as a profitable commercial entity generating wealth and power for already well-established elites close to the ruling regime.

Although it is difficult to make general statement about commercial security sectors in Africa based on one case study, the case of Angola has demonstrated to what extent the domestic commercial security sector is embedded into the President's complex patrimonial network controlling the country's power and wealth. Sometimes mimicking a public posture when operating alongside the domestic public security sector, commercial security in Angola is dominantly a private good allowing established elites to foster an emancipation of security from the oversight and control of the public. To this end, commercial security allows the MPLA's parallel state structure to widen the gap between public and private elitist security needs. That is to say, those commercial providers of security in Angola have become similar to the domestically already existing dual security sector, a counterweight to the established public security providers such as the FAA or the national police. Rather than trying to coup proof the FAA or national police by undermining its integrity through the placement of Dos Santos affiliates into organizational key positions, commercially provided security allows the regime to enhance its political influence while securing its economic and financial interests. As a consequence, African commercial security is private in nature and even though generating spill-overs to the public sphere, ultimately serves the private sectarian and commercial interests of those already involved in decades of patrimony. 


\section{REFERENCES}

Bailes, Alyson, Ulrich Schneckener, and Herbert Wulf. "Revisiting the State Monopoly on the Legitimate Use of Force." DCAF Policy Papers No. 24 (2007).

Barany, Zoltan. The Soldier and the changing State-Building Democratic Armies in Africa, Asia, Europe, and the Americas. Princeton: Princeton University Press, 2012.

Barlow, Eeben. Executive Outcomes: Against All Odds. Johannesburg: Galago Publishing, 2008.

Cammack, Paul, David Pool, and William Tordoff. Third World Politics: A Comparative Introduction. New York: Macmillan, 1994.

Chulov, Martin, and David Smith. "Libya: Gaddafi's army of mercenaries face backlash." The Guardian, September 02, 2011.

Clapham, Christopher. "African Security Systems: Privatization and the Scope for Mercenary Activity." In The Privatization of Security in Africa, edited by Greg Mills and John Stremlau, 23-46. Johannesburg: South African Institute of International Affairs, 1999.

Clark, John F. "The Decline of the African Military Coup." Journal of Democracy Vol. 18, No. 3 (July 2007): 141-155.

Clausewitz, Carl von. Vom Kriege. Berlin: Ferdinand Dümmler, 1832-34.

Cleary, Sean. "Angola: A case study of private military involvement." In Peace, Profit or Plunder? The Privatization of Security in War Torn African Societies, edited by Jakkie Cilliers and Peggy Mason. Johannesburg: Institute for Security Studies, 1999.

Creveld, Martin van. The Transformation of War. New York: Simon \& Schuster, 1991.

Cullen, Patrick. "Keeping the New Dog of War on a tight leash: Assessing means of accountability for Private Military Companies." Conflict Trends (June 2000).

Decalo, Samuel. Coups and Army Rule in Africa. New Haven: Yale University Press, 1976.

Ebo, Adebeji. "Private Actors and the governance of security in West Africa." In Private Military and Security Companies: Ethics, Policies and CivilMilitary Relations, edited by Andrew Alexandra, Deane-Peter Baker and Marina Caparini, 143-158. London: Routledge, 2008.

Edgerton, Robert E. Africa's Armies: From Honour to Infamy. Boulder: Westview, 2002. 
Hobbes, Thomas. Leviathan. Sioux Falls: Nuvision Publications, 2004.

Holmquist, Caroline. "Private Security Companies: The Case for Regulation." SIPRI Policy Paper No. 9 (2005).

Houngnikpo, Mathurin C. Guarding the Guardians: Civil-Military Relations and Democratic Governance in Africa. London: Ashgate, 2010.

Howe, Herbert. "African Private Security." Conflict Trends (June 2000).

Howe, Herbert. Ambiguous Order: Military Forces in African States. New York: Lynne Rienner, 2004.

Human Rights Watch Report. "They Pushed Down the Houses: Forced Evictions and Insecure Land Tenure for Luanda's Urban Poor." Human Rights Watch Report Vol. 19, No.7 (2007).

Huntington, Samuel P. The Soldier and the State: The Theory and Politics of Civil-Military Relations. London: Harvard University Press, 2003.

Joras, Ulrike, and Adrian Schuster. "Private Security Companies and Local Populations: An Exploratory Study of Afghanistan and Angola." Swiss Peace Working Paper No.1 (2008).

Kaldor, Mary. New and Old Wars: Organized Violence in a Global Era. 1st edition. Cambridge: Stanford University Press, 1999.

Kaul, Inge, Isabelle Grunberg, and Marc A. Stern. "Defining Global Public Goods." In Global Public Goods: International Cooperation in the 21st Century, edited by Inge Kaul, Isabelle Grunberg and Marc A. Stern, 219. New York: Oxford University Press, 1999.

Kinsey, Christopher. Corporate Soldiers and International Security: The Rise of Private Military Companies. London: Routledge, 2006.

Kinsey, Christopher, Stig Jarle Hansen, and George Franklin. "The impact of private security companies on Somalia's governance networks." Cambridge Review of International Affairs Vol. 22, No. 1 (2009): 147161.

Kisembo, Charles. "The Civil-Military Relations in Countries Emerging From Instabilities in Africa: The Challenge for the Security Sector Reform (SSR)." Joint Services Command and Staff College Defence Research Paper (2006).

Klay Kieh, George, and Pita Ogaba Agbese Kieh. "Introduction: The Military Albatross and Politics in Africa." In The Military and Politics in Africa, edited by George Klay Kieh and Pita Ogaba Agbese Kieh, . London: Ashgate, 2004. 
Klay Kieh, George. "Military Engagement in Politics in Africa." In The Military and Politics in Africa, edited by George Klay Kieh and Pita Ogaba Agbese Kieh, . London: Ashgate, 2004.

Kposowa, Augustine J., and J. Craig Jenkins. "The Structural Sources of Military Coups in Postcolonial Africa, 1957-1984." American Journal of Sociology Vol. 99, No. 1 (July 1993): 126-163.

Krahmann, Elke. "Security: Collective Good or Commodity?" European Journal of International Relations No. 14 (2008): 379-404.

Krahmann, Elke. "Private Security Companies and the State Monopoly on Violence: A Case of Norm Change?" PRIF Reports No. 88 (2009).

Krahmann, Elke. States, Citizens and the Privatization of Security. Cambridge: Cambridge University Press, 2010.

Leander, Anna. "Conditional Legitimacy, Reinterpreted Monopolies: Globalisation and the Evolving State Monopoly on Legitimate Violence." Paper presented at the annual convention of the ISA, New Orleans, March 24-27, 2002.

Locke, John. The Two Treatises of Government. Indianapolis: Hackett Publishing Company, 1980.

Luckham, Robin. "The Military, Militarization and Democratization in Africa: A Survey of Literature and Issues." African Studies Review Vol. 37, No. 2 (September 1994): 13-75.

McIntyre, Angela, and Taya Weiss. "Weak governments in search of strength: Africa's experience of mercenaries and private military companies." In From Mercenaries to Market: The Rise and regulation of private military companies, edited by. Simon Chesterman and Chia Lehnardt Oxford: Oxford University Press, 2009.

Morais, Rafael Marques de. "Private security companies and a parallel State in Angola," Africa Files (December 2007).

Mukherjee, Ramkrishna. Uganda, A Historical Accident? Class, Nation, State Formation. Trenton: Africa World Press, 1985.

Musah, Abdel-Fatau, and J. 'Kayode Fayemi. "Africa in Search of Security: Mercenaries and Conflicts, an Overview." In Mercenaries: an African Security Dilemma, edited by Abdel-Fatau Musah and J. 'Kayode Fayemi. London: Pluto Press, 2000.

Oliveira, Ricardo Soares de. "Business success, Angola-style: postcolonial politics and the rise and rise of Sonangol." The Journal of Modern African Studies, Vol. 45 (December 2007): 595-619. 
Pech, Khareen. "The Hand of War: Mercenaries in the former Zaire." In Mercenaries: an African Security Dilemma, edited by Abdel-Fatau Musah and J. 'Kayode Fayemi. London: Pluto Press, 2000.

Pollack, Kenneth M. "The Arab Militaries - The Double Edged Sword." In The Arab Awakening: America and the Transformation of the Middle East, ed. Kenneth M. Pollack, 58-65. Washington, DC: Brookings, 2011.

Roque, Paula Cristina. "Angola: Parallel Governments, Oil and Neopatrimonial System Reproduction." Institute for Security Studies Situation Report, June 06, 2011.

Roy, J. “'Polis' and 'Oikos' in Classical Athens." Greece \& Rome Vol. 46, No. 1 (April 1999): 1-18.

Vines, Alex, Nick Shaxson, and Lisa Rimli. "Drivers of Change Angola." Chatham House Position Paper No. 1 (2005).

Vines, Alex, and Markus Weimer. "Assessing Risks to Stability." Report to the CSIS Africa Program (June 2011).

Welsh, Claude E. "Emerging Patterns of Civil Military Relations in Africa: Radical Coups d'état and Political Stability." In African Security Issues: Sovereignty, Stability and Solidarity, ed. Bruce E. Arlinghaus. Boulder: Westview Press, 1984.

Wulf, Herbert. "The Bumpy Road to Re-Establishing a Monopoly of Violence." Working Paper prepared for the London School of Economics Study Group on Europe's Security Capabilities. London, United Kingdom, 2005. 


\section{ABSTRACT}

This paper focuses on the degree to which commercial providers of security in Africa are embedded into patrimonial networks catering for exclusive private security interests of certain elites. Focusing on the issue of the private or public nature of commercially provided security in Africa through the prism of normative theory, this paper rather tries to lay an exploratory foundation for the understanding of the interests driving commercial providers of security in Africa.

\section{KEYWORDS}

Public Security; Private Security; Africa. 


\section{ASYMMETRIC WARFARE: EXPERIENCES, PERSPECTIVES, INKLING AND CHALLENGES WITH A FOCUS ON ZIMBABWE}

\section{Raymond Mharapara ${ }^{1}$, Lucky Bassie Bangidza ${ }^{2}$ and Steven \\ Gwekwerere $^{3}$}

\section{Introduction}

The world has become dependent on interdependence and globalization because the processes that promote worldwide exchanges of national and cultural resources are generating further interdependence of economic and cultural activities (Robertson 2000). Therefore, one can state that religion and culture are no longer only important ingredients of civilization, but potential causes of division and isolation. A good example is that only a few Muslim governments overtly supported Saddam Hussein, many Arab States privately cheered him on, and he was highly popular among large sections of Arab populaces. When invoking parallels and using them as strong rallying points, Muslims contrasted Western actions against Iraq with the West's failure to protect Bosnia against Serbs and also to impose sanctions on Israel for violating UN resolutions (Huntington 2006, 447). As a result, differences in power and struggles for

\footnotetext{
${ }^{1}$ Mharapara is Director of the National Defence College (NDC) under the Institute of Strategic Research and Analysis (ISRA).

2 Bangidza is a Research/Facilitator at National Defence College under the Institute of Strategic Research Analysis (ISRA). A PhD student at the University of Zimbabwe. E-mail: lbbangidza@yahoo.com.

${ }^{3}$ Gwekewrere is Colonel of General Staff (GS) in the Zimbabwe National Army Headquarters.
} 
military, economic and institutional power are now sources of conflict between the West and other civilisations. Consequently, it could be assumed that fundamental economic reforms give rise to necessary political transformation.

During the Cold War, the concept of "collective security" gained popularity and significance when it meant balancing the military strength of the United States and its allies against, on the other side, Soviet Union and countries of the Eastern Bloc (Shils 1955, 105). Now that the definition refers to those non-Western countries seeking to match and/or torpedo the balance with Western nations, it is becoming increasingly clear that any state not towing U.S. path is classified an enemy. As there is asymmetric threat to Zimbabwe, the nation should however not lose sight of the fact that the presence of a threat could develop rapidly and form very dynamic circumstances. Just a misguided or misplaced machine gun could turn out to be a runaway gun or a statement to the media casting aspersions on a certain civilisation and/or religion and, therefore, could trigger such an immediate threat.

Likewise, the Zimbabwean government should strengthen processes that constantly keep at a distance the prospects of asymmetric threat. Zimbabwe should embrace collective security concept with neighboring states. Morgenthau $(1954,126)$ asserts that such collective security organisations typically require "that all nations come to the aid of a victim of aggression with all means necessary." A successful response would call for an approach that leverages the partnerships with diverse non-government actors and wields a range of disciplines, including communication, law enforcement, business and academy. It could be easily argued that soft power should have more precedence than military solutions because even as a state amass a high-tech arsenal, asymmetric threat does not necessarily allows its successful use. United States, as a hegemon, is being subtly challenged by multiple states that have strengthened their economies, enhanced their militaries, and gained increased credibility. The danger is that these rising powers and non-state actors are increasingly gaining or achieving parity and the ability to assert coveted local and regional hegemony.

To mitigate asymmetric threat there should be a grand strategy to reduce poverty and its accompanying scarcity of resources; water, food, health, employment and energy because this threat is grounded in a clash of civilization. To date we have not heard any asymmetric attacks or disruptions 
on Chinese soil, which implies that China is correctly applying its soft power and hard power approach to international relations. All states aiming at attaining hegemony status like U.S. should learn not to alienate others due to civilization or religion differences, for to do so would be creating unnecessary enmity and foster fertile ground for asymmetry from non-state actors and extremist groups, external and internal. For that reason, defensive soft power serves to keep at bay adversarial preferences, attitudes, perspectives, objectives, and modes of behavior. The recent bombings in Boston, Massachusetts (2013) indicates and proves beyond doubt that U.S. hard power would never prevail over asymmetric attacks by non-state actors and extremist groups as long as global poverty, indifference to other civilisations and religions, and failed/failing states exist. Therefore, Zimbabwe must wake up to today's realities and employ soft power: the full range of tools at disposal, diplomatic, economic, political, legal, and cultural - picking the right tool, or a combination of tools, for each situation.

In order for any state, Zimbabwe included, to realistically keep extremism and asymmetric threat at bay, elements of soft power must be exploited. Nye, Jr. (2004) defines soft power as, "the ability to get what you want through attraction rather than coercion or payments. It arises from the attractiveness of a country's culture, political ideals, and policies". When a state's policies are perceived as legitimate and just in the eyes of others, that state's soft power is enhanced. In the view of many a state's foreign policy, in particular of those states viewed as outcasts by the USA, is inherently hegemonic and designed to superintend other civilisations, religion and culture. A befitting example is the U.S.' military invasion and attack on Iraq. The U.S. managed to remove a "tyrant" but dismally failed to resolve its vulnerability to terrorism and asymmetric threat. Conclusively, as long as any state prefers other means, especially hard power, than soft power to solving problems, disputes or quarrels in international relations, the scourge of terrorism and asymmetric threat would haunt it. 


\section{Asymmetric Challenges}

The concept of asymmetric straggle has been around the world for a long time, but has become a topical issue of recent. The defence setting has been considerably complicated in recent years by rise of what has become known as "asymmetric warfare threat". In his remarks to the graduating class of the US military academy West Point, President J F Kennedy (1962) observed that "there is another type of warfare new in its intensity, ancient in its origin. War by guerrillas, subversives, insurgents, assassins, war by ambush instead of combat, by infiltration instead of aggression, seeking victory by eroding and exhausting the enemy instead of engaging him... it preys on unrest".

Simply defined, Paul $(2005,5)$ observed that

(...) asymmetric warfare is a conflict between two sides, which have a large disparity in political, economic and military power. The weaker opponent may not necessarily be a nation and increasingly could be a group representing ethnic, religious or criminal interests.

It can be simply said that its aim therefore is to weaken political resolve rather than military power and attacks could be expected far from any conventional battlefield. In asymmetric warfare, fighting occurs on the economic, political, diplomatic, social and the military front when conducive. Therefor,e one can conclude that major weapon used by the stronger sides is mainly economic, political and diplomatic through the battle for the minds. The weaker sides in turn tend to resort to generally insurgent tactics to kill the mightier power's will to fight. Seethaler et al $(2013,117)$ observed that "information and communication technologies have emerged as one of the major weapons employed by both sides engaged in asymmetric warfare".

\section{Understanding Asymmetric Warfare}

Fagan and Munck $(2009,286)$ indicated that "asymmetric warfare is mostly characterised with the battle for the mind. Always associated with the weak, asymmetric warfare has changed its form because it no longer has defined objectives". Messinger $(2001,101)$ observes that "asymmetric warfare is more a reaction than a cause". Therefore, the definition of the 'weak' has also changed. 
In simplistic terms, strategy is made up battle for the minds. If it is the battle for the minds, the interaction often involves strategies and tactics outside the bounds of conventional warfare. Tsu (2003) stated that if you employ soldiers without sorting out the skilled and unskilled, the brave and the timid, you are bringing defeat on yourself. The contour of the land is an aid to an army; sizing up opponents to determine victory, assessing dangers and distances, are the proper course of action for military leaders. Those who do battle knowing these will win those who do battle without knowing these will lose.

Generally asymmetric warfare can be a conflict involving two states with unequal overall military and economic power resources and could be individuals, groups and communities. The obvious shortcomings of this definition are to confine wars to state actors when non-state actors such as alQaeda are involved in war against states not defined geographically, but as a diaspora entity. It can easily be concluded that al-Qaeda is not concerned about attacking the territory of the state alone, but also anything associated with the state in question across the globe. The other drawback is to perceive asymmetry in terms of "overall military and economic power" sidelining the potential effect of inequalities in political and social resources, which also play an equally important role in defining the degree of asymmetry between any opponents. Realising some of these deficiencies in defining asymmetric warfare, Hess and Orthmann (2012, 382) defined asymmetric warfare as "leveraging inferior tactical or operational strength against the vulnerabilities of a superior opponent to achieve disproportionate effect with the aim of undermining the opponents will in order to achieve asymmetric actors' strategic objectives."

Unfortunately this definition only sees the bigger nations as the victims and objects of asymmetric warfare, yet the reality, especially for us in the developing world, is that the bigger nations unleash their superior tactical or operational, as well as political, diplomatic, economic and social strength against the vulnerable or weaker nations. Their aim is to undermine the weaker nations in order to achieve their strategic objectives. Chinyamakobvu (2011, 108) observed that

the Zimbabwe Democracy Economic and Recovery Act (ZDERA), is a punitive sanction measure, imposing bill hastily passed by the American Congress in December 2001. Passed into law by President George W Bush, putting a blanket 
ban on all fresh financial lending to Zimbabwe and the rescheduling of its debts by International financial institutions such as, the IMF, World Bank and the African Development Bank of which the U.S. is a member.

This piece of legislation is precisely meant to achieve the strategic objectives of the U.S.' interests and their values.

This is obviously a lesson learnt from their adventures in the Vietnam, Iraqi wars and other campaigns where they used excessive and unnecessary force, but still incurred heavy casualties, much to the humiliation of their population back home. When an attack on Iraq was imminent in 1990 following the invasion of Kuwait by Iraq, Stroilov (2011, 103) described asymmetric warfare from the perspective of a weaker adversary by saying:

If you use pressure, we will deploy pressure and force. We know that you can harm us although we do not threaten you. However, we too can harm you. Everyone can cause harm according to their ability and their size. We cannot come all the way to you in the United States, but individual Arabs may reach you.

Therefore, it is clear that everyone, big or small, is equally worried about asymmetric warfare. In the realm of military affairs and national security, asymmetry is acting, organizing, and thinking differently than opponents in order to maximize one's own advantages, exploit an opponent's weaknesses, attain the initiative, or gain greater freedom of action. It can be political-strategic, military-strategic, operational, or a combination of these. It can entail different methods, technologies, values, organizations, time perspectives, or some combination of these. It can be short-term or long-term. It can be deliberate or by default. It can be discrete or pursued in conjunction with symmetric approaches. It can have both psychological and physical dimensions. The history of asymmetry in warfare can be traced back to the antiquities and origins of war. Smith $(2004,1)$ observed Sun Tzu in The Art of War saying that "all war is based on deception". This is based on strengths and weaknesses, which today we call the threat-response dynamic. Since the time of Sun Tzu, we have seen asymmetric approaches used in every conflict. 


\section{Significances of Asymmetric Warfare}

It is important to study asymmetric warfare since it might be waged upon us when we are not aware of it like what has been the case of Zimbabwe during the past 13 years. The war sometimes assumes violence as both acceptable, necessary and draws no distinction between military and civilian targets. The enemy could inflict mass causalities on a large scale. How many people died owing to lack of proper medical care during the last couple of years as a direct or indirect effect of the illegal sanctions imposed on Zimbabwe by the West? How many Zimbabweans were eaten by crocodiles and drowned in the Limpopo trying to cross into South Africa in search of greener pastures? How many were killed or maimed in political-related violence incidence including the notorious xenophobic attacks in the Republic of South Africa? Could all these have sacrificed their precious lives if there was no sanctions and Zimbabwe Democracy and Economic Recovery Act (ZIDERA) imposed by the U.S.?

Nevertheless, asymmetric warfare will not end at an appointed hour by signing of peace agreement or declaration of a ceasefire. The arrival of this day will not be apparent at the time, but will become ever clear as the absence of mass fatality and destruction of property diminishes. Therefore, it is important to study asymmetric warfare because it is now a factor of strategic significance. It poses great challenges to defence transformation. To answer the challenges requires a shift in paradigms.

\section{Patterns of Asymmetric Warfare}

The utmost problematic pebble dashing human development today is that society is losing deep human values - integrity, compassion and respect. The society is constantly faced with temptations to compromise ethics and take a short-cut road to riches. The desires for money, sex, power and fame often translate into corruption, lies, love-affairs or crime. A minute of pleasure leads to many years of suffering. And by valuing wealth above ethics we lose everything (Nematandani 2012). World politics is entering a new phase, where we seem to be returning to traditional rivalries between nation states and the decline of the nation state from the conflicting pulls of tribalism, interdependence and globalisation among others. The fundamental source of 
struggles in this new world will not be primarily ideological or economic as was during the cold war. The great divisions among mankind and the dominating source of conflict will be cultural. Nation states will remain the most powerful actors in world affairs, but the principal conflicts of global politics will occur between nations and groups of different civilisations. Therefore, the next pattern of conflict is the clash of civilisations as the battle lines. Is it a clash of civilisation or a clash of interests?

\section{Conflict between Civilisations}

Crothers and Lockhart $(2000,100)$ observed that the "conflict between civilizations will be the latest phase in the evolution of conflict in the modern world". Conflicts of the western world were largely among princes, emperors, absolute monarchs and constitutional monarchs attempting to expand their bureaucracies, their armies, their mercantilist economic strength and most important, the territory they ruled. In the process they created nation states, and, beginning with the French Revolution, the principal lines of conflicts were between nations rather than princesses, until the end of World War I. As a result of the Russian Revolution and the reaction against it, the conflict of nations yielded to the conflict of ideologies, first among communism, fascismNazism, liberal democracy and capitalism/ imperialism. During the Cold War, this latter conflict became embodied in the struggle between the two superpowers, neither of which a nation state in the classical sense defined more in terms of ideology.

These conflicts between princesses, nation states and ideologies were, for the West, primarily regarded as "the clash of civilisations or western civil wars". This was also true for the cold war and the earlier wars of the seventeenth to the nineteenth centuries. With the end of the Cold War, international politics moved out of its Western phase, and its centre-piece became the interaction between the west and among non-western civilisations. In the politics of civilisations, the people and governments of non-western civilisations no longer remain the objects of history as targets of western colonialism, but join the West as movers and shapers of history. 


\section{Nature of Civilisation}

During the Cold War, the world was divided into the first, the second and the third worlds. Those divisions are no longer relevant. It is far more meaningful now to group countries not in terms of their political or economic systems or in terms of their level of economic development but rather in terms of their culture and civilisation. Huntington $(2000,43)$ observes that "civilisation is a cultural entity. Villages, regions, ethnic groups, nationalities, religious groups, all have distinct cultures at different levels". The culture of a village in southern Zimbabwe may be different from that of a village in northern Zimbabwe, but both will share in common Zimbabwean culture that distinguishes them from Malawian villages. Huntington also observed that

European communities, in turn, will share cultural features that distinguish them from African, Arab or Chinese communities. Civilization is thus the highest cultural grouping of people and the broadest level of cultural identity people have, short of that which distinguishes humans from other species. It is defined both by common objective elements, such as language, history, religion, customs, institutions and by the subjective self-identification of people (Huntington 2000, 43).

People can and do redefine their identities and, as a result, the composition and boundaries of civilisations change. One can now put the onslaught of Britain and her allies, from Australia to the U.S., on Zimbabwe into context. They constitute the western civilisation.

Civilisations may involve a large number of people, as with China, or a very small number of people such as Swaziland a country in a womb of another country. Huntington (1993) says that

(...) a civilisation may include several nation states, as is the case with western and Islamic civilisations, or only one, as is the case with the Japanese civilisation. Civilisations obviously blend and overlap, and may include sub civilisations. Westerners tend to think of nation states as the principle actors in global affairs.

Westerners have been like that, however, for only a few centuries. But the broader reaches of human history have been the history of civilisations, development and progress. 


\section{Torn Countries}

In general, parliamentarians exercise their power and attitudes to the duty of representing the citizen's interests. Instead, in many cases, according to Santoni and Mair (2005),

(...) parliamentarians are interested in party political interests and discipline. At the individual level, the parliamentarians are often eager to remain in the good books of influential officials of both civilian and military decision-making bodies. They worry more about maintaining good relations with the President or Prime Minister rather than looking after those who elected them.

With such a scenario, it can be safely interpreted as asymmetric warfare by our own citizens, because of being partocratic than being nationalistic in approach. This is another form of dangerous warfare, sometimes more difficult to determine and define.

It can effortlessly be pointed out that states can just as systematically be disrupted and destroyed by internal challenges (at the sub-state or from the national level) as they can be by external forces. The Democratic Republic of the Congo (DRC) is a good example of domestic rebellion (such as the repeated secession attempts by Katanga during the 1960s), predatory governance (under Mobuto Sese Seko) and foreign invasion (by Uganda and Rwanda in 1998) - all three of which undermined national security. It could be easily said that the challenge in Africa today is that national security is equated with that of the governing elite - 'governing' in the interests of their own preservation and advancement, with limited provision of human security for their citizenry.

However, some countries have a fair degree of cultural homogeneity but are divided over whether their society belongs to one civilisation or another. These are torn countries. Their leaders typically wish to pursue a strategy and to make their countries member of the west, but the history, culture and traditions of their countries are non- western. Crothers and Lockhart (2000, 113) said that, "the most obvious and prototypical torn country is Turkey". Turkish leaders have defined Turkey as a modern, secular, western nation state, allying Turkey with the west in NATO. During the Gulf War, Turkey applied for membership in the European Community but elements in the Turkish society have supported an Islamic revival arguing that Turkey is basically a 
Middle Eastern Muslim society. The elite of the west also refuse to accept Turkey as part of the western society. In Crothers and Lockhart (2000, 13), one of the Turkey Presidents said that, "Turkey will not become a member of the European community and the real reason is that we are Muslim and they are Christian and they don't say that". Encouraged by the west, Turkey is making strenuous effort to carve out this new identity for itself.

\section{The Clash of Civilisations}

Civilisation identity will possibly increase its important in the future. Fox (2001) observed that "the world will be shaped mainly by interactions among seven or eight major civilisations and they are Western, Confucian (Chinese), Japanese, Islamic, Hindu, Slavic-orthodox, Buddhist and possibly African civilisation". Why will this be the case? Huntington (1993) pointed out that differences among civilisations are not only real; they are basic, clans taking care of their own. Civilisations are differentiated from each other by history, language, culture, tradition and most important religion. Hatem (2000) said that

(...) people of different civilisations have different views on the relations between God and man, the individual and the group, the citizen and the state, parents and children, husband and wife, as well as differing views of the relative importance of rights and responsibilities, liberty and authority, equality and hierarchy. These differences are the product of centuries and will not soon disappear. They are far more fundamental than differences among political ideologies. Differences do not necessarily mean conflict, and conflict does not necessarily mean violence.

Huntington (2002) said that, "over the centuries however, differences among civilisations have generated the most prolonged and the most violent conflicts". Does this idea attempt to explain the upheavals in the Middle East and North Africa?

In International Relations, the elaboration is on the theory of interdependence to break down boundaries and differences in order to enhance economic and social interactions. Huntington (1993) observed that, the world is becoming a smaller place and interactions between peoples of different 
civilisations increasing thus intensifying consciousness and awareness of differences between civilisations and commonalities within civilisations. A Mumanyika could be Mujindwi, Mugarwe, Mundau, Barwe, Manyika, in Manicaland, simply Samanyika in Harare, a Zimbabwean in Windhoek and an African in Beijing. Ulusoy (2004) observed that "the interactions among peoples of different civilisations therefore enhance the civilisation-consciousness of people and, in turn, invigorates differences and animosities stretching or thought to stretch back deep into history". Does this explain the Hutu Tutsi issue?

Huntington (1993) observed that economic modernisation and social change throughout the world are separating people from longstanding local identities and weaken the nation state as a source of identity. In much of the world, religion has moved in to fill this gap, often in the form of movements that are labelled fundamentalist. Such movements are found in Western Christianity, Judaism, Buddhism and Hinduism, as well as in Islam. General observation according to Huntington indicates that, in most countries and most religions, the people active in fundamentalist movements are young, collegeeducated, middle- class technicians, professionals and business persons. Does this explain the emergence of the Makandiwas, Pastor Chris, and Dr. Utaunashe groups in Zimbabwe?

Ritzer and Atalay (2010) observed that the growth of civilisation, consciousness in the west is at the peak of power, whilst there is a tendency of returning to the roots phenomenon occurring among non-western civilisations. Hence, increasingly we hear of the "Hindunisation" "Westernisation versus Russianisation in Russia". Does this explains the emerging alliances like Brazil, Russia, India, China and South Africa (BRICS) and the waning of the nonaligned movement? In the past, the elites of the Zimbabwean society were usually the people who were most involved with the west. They were educated at Oxford and trained at Sand Hurst, and absorbed western attitudes and values whilst the populace remained deeply imbued with or inspired by indigenous culture. There is need to de-westernise and indigenise the minds of the elites in Zimbabwe and at the same time that American cultures, styles and habits should not become more popular among the people. Does this explain the Look East Policy vs. Zhing Zhong mentality in Zimbabwe? 


\section{Multi-Dimensional Challenges}

Different nations understand asymmetric warfare differently and according to their environment. It can be concluded that for the British and Americans, asymmetric warfare is a multi-dimensional conflict which is fought simultaneously on the economic, political, diplomatic, social and sometimes concurrently on the military front. These are termed the instructions of power, commonly known for diplomatic (and political), information, military and economy. In Zimbabwe, the wanton destruction of anything considered to be "government property" in the run-up to the 2000 general election and 2002 presidential election was evidence of an economic front in asymmetric warfare. The defacing of road signs and destruction of basic structures like the rail, electric line, bus terminals and telecommunication lines appeared on the surface to be just other acts of civil disobedience, but that was the real face of asymmetric warfare on the economic front. The objective here was to exploit the weakness identified within the nation and use the local people to destroy their own economy. Zimbabweans were complicit with the destruction of the Zimbabwean economy between 2000 and 2008. The so-called captains of industry were steering the economy off course. An analysis of the situation in Zimbabwe during the period 2000-2008, shows that the country had been attacked on the economic front by the imposition of sanctions, ZDERA, economic sabotage, illegal money deals which resulted in what the Governor of the Reserve Bank of Zimbabwe DR Gono would call the casino economy in 2008 .

The flight of skilled labour to other countries, maladministration, hoarding of basic commodities, and closure of the production industry characterised that period and there is no classical economic theory which explains why the Zimbabwean Dollar would lose its value at such a rate. In the morning the exchange rate would be 1:15 million, by noon, it is 1:100 million. In all these activities, you will see that locals were the foot soldiers against their own economy, some knowingly but some specifically or specially recruited for that campaign against the Zimbabwean state. The conditions of the civil servants were and are still horrendous; the basic human approach was the target. The result was a shortage of nearly everything from the very sensitive things like sanitary pads, medicines etc. Our opponents then used these 
shortages as a reason to argue that Mugabe had lost all legitimacy to rule. Zimbabweans also executed field burials at 'Mbudzi' cemetery against our culture owing to fuel shortages, cash or both. Attacks on the political and diplomatic front capitalising on weakness or shortfalls, which were blown out of proportion and politically internationalised. In recent years and in many countries the focus has been on constitution making. What was the interest of the EU and its allies in Zimbabwean constitution making process?

\section{Terrorism and Insurgents}

While many terrorist actions are relatively low in technology, one should not assume that weak opponents would not have access to high technology. Perhaps the only characteristics of asymmetric warfare that can be stated with certitude are that it is applied suddenly and unexpectedly. Examples are 9/11, Bali, Kenya and Tanzania bombings, just to mention a few. Asymmetric approaches employ or affect one or more of the elements of national power (military, political, diplomatic, economic and information). Asymmetric warfare generally seek a major psychological impact, such as shock or confusion that affects an opponent's initiative, freedom of action or will. Asymmetric approaches often employ innovative, non-traditional tactics, weapons, or technologies and can be applied at all levels of warfare and across the spectrum of military operations. It is generally employed to achieve results disproportionate to invested effort.

Now that we have examined the characteristics, weapons, and forms of asymmetric warfare, how is it possible to protect or plan against an asymmetrical attack? The nature of the "threat-response dynamic" is to analyze all real and perceived threats and vulnerabilities to produce a counter measure or reinforcement to a vulnerability. It will never be possible to fully protect against an asymmetric attack, as there are limited resources and an almost infinite number of scenarios to be considered. The best that any state or nonstate can hope for is that intelligence is leveraged in such a way to create a list of most likely scenarios to guard against. It is a vicious circle, for the act of analysis and response constantly produces additional threats and vulnerabilities as resources are shifted to compensate for perceived or real threats and vulnerabilities. At the core of this dynamic is intelligence; not the quantity of 
intelligence, but the quality of both the data and the analysis. Any state or nonstate that wishes to be successful in countering asymmetric threats or attacks must have a productive and accurate intelligence system in place. This intelligence system should be responsible for the collection, dissemination, and analysis of data in response to balanced priorities set by the states or organisations leadership. The leadership can be either centralised or decentralised from the perspective of the intelligence system.

In addition to a normal collection, analysis and reporting process, an alerting system based on the concept of "management by exception" must be put in place and tied to early warning systems, which are designed to monitor changes in antagonist activities and escalate reports via a separate and distinct chain of command. Only with accurate, timely, and complete intelligence can an organization, state or non-state, hope to protect itself against asymmetric threats.

\section{Conclusion}

Asymmetric warfare is not something new, since wars have never been fought by equal opponents. Enemies will always have some political, social and economic asymmetry, or in terms of overall military capability. Asymmetric warfare's objective is to weaken political resolve rather than military power through attacks away from any conventional battlefield. It is fought on the economic, political, diplomatic, social and military fronts when it is conducted. It is the battle for the minds, and, therefore, tactics vary constantly, since each application is unique. It is important to study asymmetric warfare to avoid surprises. It is a war of ideas where the centre of gravity lies in the hearts and minds.

Villages, regions, ethnic groups, nationalities, religious groups, they all have distinct cultures at different levels. A civilisation is thus the highest cultural grouping of people and the broadest level of cultural identity. Civilizational identity will be increasingly important in the future, and future conflicts are likely to be civilisation-oriented as peoples scramble for resources.

Different nations understand asymmetric warfare in distinct ways. Weaker sides, however, could use other tactics - including terrorism - to 
achieve the same goals. Asymmetric approaches employ or affect one or more of the elements of national power, besides seeking a major psychological impact. Innovative, non-traditional tactics, weapons, or technologies are applied at all levels, from strategy down to tactics, in order to achieve results disproportionate to invested effort. It is a mental battle, exploiting your strength against an enemy's weakness and recognising that all areas of human endeavour are part of the battleground and counterbalance any lack of conventional force. It cuts across all human spectrums: political, economic and social. Asymmetric warfare can hit anytime, anything, anywhere. It might occur through greed and failing moral character, and can be used surreptitiously, maintaining the outward appearance of peace while softening up the opponent. Therefore, asymmetric warfare encompasses a wide scope of theory, experience, conjecture and definition, the implicit premise is that it deals with the unknown, with the surprise in terms of ends, ways and means. 


\section{REFERENCES}

Chinyamakobvu, Emmanuel. 2011. The Farm on Their Land. Bloomington: Author House.

Crothers, Lane; and Charles Lockhart (eds.). 2000. Culture and Politics: A Reader. New York: St. Martins Press.

Fagan, G. Honor; and Ronaldo Munck. 2009. Globalization and Security: Social and Cultural Aspects. Santa Barbara: Greenwood Publishing Group.

Fox, Jonathan. 2001. "Clash of Civilizations or Clash of Religions - Which is a more Important Determinant of Ethics Conflict?" Ethnicities, 1 (3): 295-320.

Hatem, Mervat Fayez. 2006. "In the eye of the storm: Islamic Societies and Muslim Women in Globalization Discourses". Comparative Studies of South Asia, Africa and the Middle East, 26 (1): 22-35.

Hess, Kären Matison; and Christine Hess Orthmann. 2012. Introduction to Law Enforcement and Criminal Justice. Independence: Cengage Learning.

Huntington, Samuel Phillips. 1993. "The Clash of Civilizations?". Foreign Affairs 72 (3): 22-28.

Huntington, Samuel Phillips. 2006. "The Clash of Civilizations?". In Twentieth

Century Political Theory: A Reader, edited by Stephen Eric Bronner, 439-456. New York: Routledge.

Huntington, Samuel Phillips. 2007. The Clash of Civilizations and the Remaking of World Order. New York: Simon and Schuster Paperbacks.

Kennedy, John Fitzgerald. 1962. "Remarks to the Graduating Class of the US Military Academy West Point". Speech made at New York, U.S., June.

Messinger, Gary S. 2011. The Battle for the Mind: War and Peace in the Era of Mass Communication. Amherst and Boston: University of Massachusetts Press.

Morgenthau, Hans Joachim. 1954. Politics among Nations: The Struggle for Power and Peace. New York: Alfred Knopf.

Nematandani, Kirsten. 2012. "Welcome Address by Mr. Kirsten Nematandani, South African Football Association President". Speech made at the FIFA-Interpol-COSAFA Integrity Workshop, Johannesburg, South Africa, August. 
Nye, Jr., Joseph S. 2004. Soft Power: The Means to Success in World Politics. New York: Public Affairs.

Paul, Thahza Varkey (ed.). 2001. The India-Pakistan Conflict: An Enduring Rivalry. New York: Cambridge University Press.

Robertson, Roland. 2000. Globalisation: Social Theory and Global Culture. London: SAGE Publications.

Sartori, Giovanni. 2005. Parties and Party Systems: A Framework of Analysis. Colchester: ECPR Press.

Seethaler, Josef; Karmasin, Matthias; Melischek, Gabriele; and Romy Wöhlert (eds.). 2013. Selling War: The Role of the Mass Media in Hostile Conflict from World War to 'War on Terror'. Chicago: The University of Chicago Press.

Shils, Edward. 1955. "Security and Science Sacrificed to Loyalty". Bulletin of the Atomic Scientists, XI (4) - Special Issue, April.

Smith, Charles Robinson. 2004. Deception: How Clinton Sold America Out to the Chinese Military. Columbus: The Pine Lake Media Group.

Stroilov, Pavel. 2011. Behind the Desert Storm: A Secret Archive Stolen from the Kremlin that Sheds New Light on the Arab Revolution in the Middle East. Chicago: Price World Publishing.

Tzu, Sun. 2003. The Art of War: Complete Text and Commentaries. Boston: Shambhala Publications.

Ulusoy, Hasan. 2004. "The Importance of Identity Building in Avoiding The Clash of Civilisations in The Age of Globalisation (With Some Reflections On Turkey-EU Relations)". SAM - Centre for Strategic Research. Available at: <http://sam.gov.tr/swpcontent/uploads/2012/01/Hasan-Ulusoy4.pdf $>$. Accessed March 30, 2013. 


\section{ABSTRACT}

This article offers an asymmetric warfare analytic conception through suggesting that asymmetric threats should be viewed in terms of the battle for the minds. With reference to the knowledge of asymmetric struggle, its patterns, conflict between civilisation and its nature in torn countries, clash of civilisation and its challenges, terrorism and insurgents, this work presents examples from the international level with the main thematic focus on Zimbabwe. The article suggests that there is a high level of asymmetric warfare ignorance among many and that asymmetric threats serve elite's national economic interests. It also suggests possibilities of protection or planning against an asymmetrical attack, bearing in mind that asymmetric warfare is a war of ideas where the center of gravity lies in the hearts and minds of the people.

\section{KEYWORDS}

Asymmetric Warfare; Civilisation; Interdependence; Globalization; Culture. 



\title{
TOWARDS REDEFINING THE NEWS AGENDA IN THE NIGERIAN MEDIA FOR NATIONAL DEVELOPMENT
}

\author{
Osakue Stevenson Omoera ${ }^{1}$
}

\section{Introduction}

The media (radio, television, film, print, social networks, etc) are change agents in contemporary world. They can be/should be deployed to ensure the culture of peace as well as galvanise other agents of development in 21 st century societies, especially in Africa, where peace and sustainable development appear to be eluding many countries, including Nigeria, Sudan, Zimbabwe, Democratic Republic of the Congo, Ivory Coast, Somalia, to mention a few. Appraising the state of affairs in Nigeria, Igbuzor (2006) warns that several intelligence reports on Nigeria indicate that if the country is unable to create about 24 million jobs for its growing population, to provide effective platforms and infrastructures for fighting corruption, and to ensure equitable distribution of its abundant wealth, it could become a failed state.

The questions of youth restiveness, unemployment and all shades of crime have taken a dominant space in global discourse, even as youth intransigence is threatening to shred the fabric of the Nigerian society (Ugor 2009; Onuoha 2009; 2010; 2011; Omoera 2013). If this were to happen, it will not only unsettle Nigeria, but disrupt the relative peace and security in West Africa and indeed the African continent as a whole. This is a grave issue that

1 Lecturer in Media and Theatre Studies, Ambrose Alli University, Ekpoma, Nigeria. E-mail: omoera@yahoo.com. 
demands urgent attention considering the position of Nigeria in the sustenance of peace in the West African sub-region and indeed the whole of Africa.

Nigeria is located in the West of Africa and it is the largest black nation on planet earth, with a population of about 170 million people (Omoera and Aihevba 2012). It occupies 923, 768.64 sq. kilometres, roughly sharing international boundaries with Benin in the West, Niger and Chad in the North, Cameroon in the East and the Atlantic Ocean in the South. Nigeria has over 450 indigenous languages spoken within its borders (Hansford, Bendor-Samuel and Stanford 1976; Grimes 2000; Anyanwu 2011; 2012). It is a multi-faith, multilingual and multicultural country. By October, 2014, Nigeria will be 54 years, having attained political independence in 1960.

However, Nigeria is beset by a lot of issues, ranging from the emergence of ethnic militias/terrorists groups such as Egbesu, Odua Peoples' Congress (OPC), Boko Haram, etc, to general insecurity of lives and properties; pervasive official corruption to failing public infrastructures; self-serving political class to despondent, crime-prone youth populations, grinding poverty to religious indignities, to mention a few. All these appear to have culminated in the clogging of the wheel of peace, progress and development of the country, which was once touted to be the 'giant of Africa' but with so many failed promises in spite of its huge potentials. This study uses Nigeria as a reference point for the African situation because whatever happens in Nigeria tends to reverberate across the African continent.

\section{Theoretical Grounding}

Theoretically, the agenda setting theory (AST) of the media as put forward by Maxwell McCombs and Donald Shaw (1972) and refigured by Stanley Baran (2002) provides an intellectual foundation for this study. McCombs \& Shaw $(1972,176)$ during their very influential research on the role of the media in the 1968 presidential elections of the United States of America, observe that:

In choosing and displaying news, editors, newsroom staff, and broadcasters play an important part in shaping political reality. Readers learn not only about a given issue, but also how much importance to attach to that issue from the amount of information in a news story and its position $[\ldots]$ the mass media may well 


\section{Osakue Stevenson Omoera}

determine the important issues - that is, the media may set the "agenda" of the campaign.

Overtime, AST research has demonstrated that the more stories the news media do on a particular subject, the more importance audiences attach to that subject. In relation to AST, Baran holds that the "media may not tell us what to think, but media certainly tell us what to think about" (2002). He further argues that the agenda setting power of the media resides in more than the amount of space or time devoted to a story and its placement in the broadcast or on the page. Also important is the fact that there is a great consistency between media sources across all media in the choice and type of coverage they give an issue or event. This consistency and repetition signal to the people the importance of the issue or event.

Campbell, Martin and Bettina (2007) largely agree with the foregoing. They posit that when the mass media pay attention to particular events or issues, they determine - that is, set agenda for - the major topics of discussion for the individual and society. This compass of proven capacity of the media to determine what should dominate public discourse for reasons of accelerating socio-economic and socio-political development in contemporary society has been rearticulated and reformulated by a number of other media scholars (Banda 2006; Sambe 2009; Ugulah 2009; Ibagere 2009; Ahmad and Ashara 2009; Zhang, Shao and Bowman 2012). This is particularly in relation to refocusing the news agenda of media for national development in different parts of the globe.

It is in this context that this study examines the crucial role the media have been playing/ought to be playing/should be playing in the sustenance of peace and the galvanization of sustainable development in Nigeria as a microcosms of Africa. It specifically posits that the culture of peace can ensure the security of lives and properties in the Nigerian society and the society, in turn, stands a greater chance of being economically, socially, politically as well as culturally developed, if the agents of development such as the media and their operators/professionals diligently and dispassionately carry out their responsibilities. 


\section{A Brief Historical-Analytic Survey of the Nigerian Media}

The Nigerian media predates Nigeria as a country. Ufuophu-Biri (2006) traces media activities in Nigeria to 1859, when Iwe Irohin, a newspaper (print media) was established in Yorubaland (now Western Nigeria) by a Scottish reverend, Henry Townsend. This opened the floodgates of print journalism in pre-colonial and colonial Nigeria. Subsequently, Robert Campbell published a newspaper called Robert Campbell's Anglo African Newspaper in 1863. Among many others that followed, there were The Lagos Times (1880), Lagos Observer (1882), The Lagos Standard (1908), The Nigerian Chronicle (1908). The next fifty years saw, on the one hand, the emergence of more provincial newspapers such as Gaskiya Tafi Kobo, The Nigerian Eastern Mail, Lagos Daily News, etc., and on the other hand, nationalistic newspapers such as The African Messenger, The Daily Times, The Tribune and The West African Pilot.

For instance, while Babajo (2008) notes that the production of Gaskiya Tafi Kobo, a newspaper written in Hausa by Gaskiya Corporation of Zaira in 1938, marks the beginning of actual newspaper journalism in the northern Nigeria, The West African Pilot produced by Dr. Nnamdi Azikiwe led the pack of critical minded newspapers that served as platforms for Nigerian nationalists to ventilate their views towards the attainment of political independence in 1960. From the 1960s till date, there has been an avalanche of newspaper and magazine titles, both regionally and nationally in Nigeria. Some of these include The Nigerian Observer, The Punch Newspaper, The National Concord, The Guardian, Vanguard, The Newswatch, The Daily Champion and Tell Magazine.

As regards the broadcast or electronic media in Nigeria, the showing of a film at the Glover Hall in Lagos in 1903, which is touted to be the first of its kind (Opubor and Nwuneli 1979), could be regarded as its historical commencement. Importantly too were the largely propagandistic broadcasts through radio redistribution services during the colonial/pre-independence period. Omoera and Okhakhu (in press) contend that, at that point in the Nigerian history, the British authorities deployed the broadcast media to brainwash Nigerians to blindly support and advance the imperialist policies of the British Empire. As early as the 1930s the British colonialists had started a wired radio system and continued to operate as such until 1949, when the first wireless broadcasting was setup under the auspices of the post and telegraph department. Two years later (1951), the Nigerian Broadcasting Service (NBS) 


\section{Osakue Stevenson Omoera}

was created as a separate department. In 1957, the NBS was changed to Nigerian Broadcasting Corporation (NBCl) under the corporation act (NBC1 ordinance, No.39 of 1956), with national and regional services based in Lagos, Enugu, Kaduna and Ibadan.

Today, the Nigerian media is one of the fastest growing media ecologies in Africa. From virtually nothing some 60-plus years ago, Nigeria now has over 300 radio and television stations and a complex network of broadcast operations such as the Channels TV Network, the African Independent Television (AIT) Network, Ray Power FM, Silverbird Television, and Rhythm FM besides the largest TV network in Africa, the Nigerian Television Authority (NTA) and its sister network, Federal Radio Corporation of Nigeria (FRCN). Thus, the broadcast media ownership structure in Nigeria at present is public (in the case of NTA, for example) and private (in the case of AIT, for example) oriented but under the regulatory umbrella of the National Broadcasting Commission, or NBC2 (Okhakhu and Omoera 2010a).

\section{Towards refocusing the news agenda in the Nigerian media for national development}

Hide nothing from the masses of our people, tell no lies, and expose lies whenever they are told. Mask no difficulties, mistakes, failures. Claim no easy victories. (Amilcar Cabral 1979)

Perhaps, the forgoing words in marble speak to the need for a more robust and confident media that will be willing to hold to account those in government, media professionals (themselves) as well as the populace on issues of national importance which are critical to the speeding up of socio-economic and socio-political development of Nigeria. Although Okhakhu and Omoera (2010b), while reflecting on the Edo State, Nigeria, situation with regard to the functioning of media as agents of development, assert that the media have tried in a number of fronts, Omoera and Okhakhu (in press) argue that the Nigerian media still need to do more professionally to objectively report and interpret events for peace and national development. For instance, a situation where over five hundred (500) local government councils out of the seven hundred and 
seventy four (774) in the country have been illegally headed by council chiefs handpicked by the various governors across the country for over three (3) years now is unbecoming, undemocratic, and capable of threatening the fragile peace and stability of the country. Media professionals through newspaper articles, broadcast news analysis, commentaries, among other programmes on radio and television ought to have extensively examined this ugly situation, interpret its various scenarios and implications and even petition concerned authorities such as the judiciary for constitutional interpretation and adherence to the rule of law.

Unfortunately, the Nigerian media have yet to handle the bull by the horns in this regard and indeed other knotty national issues of the day. Some media operators are wont to respond to the above accusation with mediocre statements such as 'My family still needs me'; 'my children are still very young'; 'one should not put the society problem on one's head because if one dies, society will not remember one let alone one's family'; 'I don't want to get kidnapped'; 'I don't want to get bombed'; 'I don't want to have headaches or sleepless nights over other people's wahala'; 'I don't want to be caught in a crossfire of political gladiators'; and so on. While these points may be valid or tenable in the circumstances Nigeria has found itself, the fact remains that one must live or die for something and if an altruistic/patriotic effort aimed at making the society a better place for the greater number of the populace kills one, posterity is bound to record it in one's favour and remembrance. The Dele Giwa's story may suffice in instantiating the point being canvassed. Consequently, media professionals should rise to the occasion to stem the observable growing culture of political disenfranchisement of well-meaning persons, virtual emasculation of the third tier of government in Nigeria, flagrant abuse of the rule of law for selfish political ends by those who see themselves as 'sacred cows' in the Nigerian political firmament.

Furthermore, the Nigerian media, both print and broadcast should find a way of reducing rumour-mongering and outright misinformation of the public on certain government policies, without being seen as grovelers or political jobbers. For instance, the events leading to the presidential media chat of 18 November 2012, on NTA are clear cases in point. For over a week leading Nigerian media, both print and electronic, were awash with news items in which the president was quoted to said that fuel subsidy would be totally removed in 


\section{Osakue Stevenson Omoera}

December 2012. Following this information from media sources, Nigerians were now 'gearing' up for a showdown only for the president to clear the air with an instructive remark that if his government proposed anything of such there would not have been any need for an budgetary allocation for fuel subsidy in the 2013 budget. This is a pointer to the challenge of mediocre reporting, which a considerable number of Nigerian journalists have been accused of. Many journalists hardly do serious background research before going to press and this has contributed to the heightening of tension in the Nigerian polity. The media should check their facts, figures before going to press in order not to overheat the polity.

The Nigeria media must refocus in their crusade of reorienting Nigerians on the need to pursue national interests with vigour and patriotic zeal. Many Nigerians and even non-Nigerians have lost faith in the salvation of Nigeria. Apparently, this loss of faith has been precipitated by the many years of military interruptions, political debauchery, economic balkanization and the lack of foresightedness of persons that have been at the helm of affairs at one time or the other in the country. Nonetheless, the Nigerian media must now take it as their responsibility, albeit, an onerous one, to mobilize through objective news reporting and coverage, human and material resources to 'deschool' Nigerians from this dangerous standpoint and commence the process of confidence building among the populace. Well thought out media programmes or articles aimed at encouraging Nigerians to be patriotic, altruistic and security conscious should be regularly aired or published. It is worth mentioning that most newscasts in some broadcast channels in Nigeria now begin and end with security tips and what one may call 'psycho pep talks'. The security tips are mainly on safety precautions and vigilance in a Boko Haram era Nigeria. This kind of innovation should be fine-tuned and replicated in the Nigerian print media too.

Without mincing words, Nigeria is still a very peripheral economy in the global economic space. This is largely because it is crude oil-dependent, with over $90 \%$ of its national revenue accruing from the oil sector. Besides the fact that crude oil is an exhaustible resource, depending on it in a $21^{\text {st }}$ century world can make peace and sustainable development to elude the country. It is in view of this that the Nigerian media must set the agenda through intrepid and 
balanced news reports that readily engage the Nigerian political as well as economic leadership on the urgency of the need to refocus Nigeria towards a poly-economy, with multi-revenue sources and the production of goods/services of higher values. Studies have lamented that countries which have more crude oil than Nigeria are more diversified, advising the country to diversify into nonoil sectors rather than wholly depending crude oil (Omoera 2010a; Haussman 2012; Aisien and Oriakhi 2012). The Nigerian media can begin to set the economic agenda through innovative insistence that there cannot be any meaningful development in Nigeria if its economy is not diversified. In fact, media catchphrases such as 'the process of diversification is the process of development' will not be out of place, to drum into the ears of those that hold the reins of power to stop 'earmarking' but practically explore other streams of revenue for the country. For instance, Omoera (2010a) argues that the media, particularly television, hold many potentials in reinventing the tourism industry for the socio-economic and socio-cultural transformation of Nigeria.

To achieve the foregoing, the Nigerian media need to encourage and lobby the Nigerian legislature to compel managers of the Nigerian economy to concretely diversify and squarely break the electric power generation quagmire. Such a deliberate effort will help to accelerate productive activities in the economy. Overtime, a large percentage of the Nigerian populace, especially the youth, can become productively engaged, thereby reducing antisocial tendencies that can threaten peace in the society. Again, the Nigerian media must refocus in their monitoring of national budget implementation and service delivery of both public and private organizations for national development. Aside from the provisions in sections 22 and 39 of the Constitution of the Federal Republic of Nigeria (1999), which empower the media to monitor governance, and uphold openness and accountability in government, the Nigerian media should effectively deploy the Freedom of Information Act (FOIA), which was recently passed into law, to get the Nigerian polity to work through getting the people and structures to function. In other words, media professionals in Nigeria must boldly set the agenda of fast-tracking development at the socio-economic and socio-political fronts in the country. They must go beyond the traditional routine news reporting activities.

The Nigeria media must also take the lead in recognising and celebrating national symbols, heroes, values and history for national 


\section{Osakue Stevenson Omoera}

development. Igbafe (2006) contends that a country like Nigeria whose historical circumstances have exposed it to the devastating impact of foreign rule and influences and which is still struggling to be properly welded together as a nation, needs to rehabilitate its sense of history, values and national symbols. The Nigerian media must set the agenda, through their news coverage, in celebrating positive heroes and peace symbols such as the Nigerian coat of arms, the Nigerian green-white-green flag, personalities (for instance, Yakubu Gowon, Wole Soyinka and Philip Emeagwali), sports victories, etc, to serve as emblems of inspiration to the younger generations who will prepared to give their all towards achieving national ideals. This subtle but concrete effort can help to rebuild in both old and young Nigerians the confidence needed to believe in their abilities to contribute to a united and integrated country erected on a foundation of knowledge of common past and a mutual understanding of a progressive future in an atmosphere of peace.

Media professionals in Nigeria should see the reimaging of the country as a task that must be done to breed a 'tribe' of constructive mentors and mentees whose avowed commitment to national development will be unshaken and unshakeable come what may. Towards this end, print and broadcast contents which extol the virtues of national symbols and ideals should be propped up to serve as propagators of a belief system such as "Nigeria and Nigerians can'. Coupled with this is that the Nigeria media hold it as a duty to rearticulate their surveillance propensities and capacities in aid of security operatives to ensure peace and development. Nigerian media professionals must proactively respond to the current security scare of kidnapping, armed robbery, gang rapes, among other crimes, which are on the increase in Nigeria by providing print and broadcast contents which can help security personnel as well as the general public, with useful information to nip crime in the bud or put in check those persons with antisocial tendencies that can threaten the peace of the land. It would also be profiting for Nigerian journalists to take advantage of ICTs to encourage 'citizen journalism', which will make the Nigerian populace to readily empathize and provide them with useful information that can help in reducing the seeming intractable security challenge confronting the country.

The Nigerian media must begin to de-emphasise mere routine reportage of news that pander to the whims and caprices of selfish political leaders at 
various levels of government in Nigeria. For instance, it is high time the Nigerian media stopped giving front-page news status to news reports such as local government (LG) chairmen grading earth roads, evacuating refuse from local markets, providing local schools with stationery, etc. Ordinarily, such activities are part of their statutory duties, which have been provided for in a budget. Aside from questionable showmanship, there is nothing ingenious or innovative about such engagements. Therefore, Nigerian media professionals can do well to take the LG chiefs to task on their budget implementation because budget implementation is a framework or index of development. It should also be part of setting the agenda for development for the Nigerian media to do more of investigative journalism in order to keep both public and private individuals and organizations on their toes to achieve set deliverables. A situation where high profile corruption cases such as the Julius Berger, fuel subsidy heist, Siemens, Halliburton and banking sector scandals remain largely unresolved does not inspire any confidence in the system and must be avoided.

Another vexatious trait of many a Nigerian media outfit today is the biased but presumptuous reportage of one-sided news items and the use of sickening prehistoric clichés that smacks of journalistic laziness and nonseriousness of purpose. For instance, on the NTA network news at 9 P.M. on Wednesday 24, 2009, the then minister of education, Dr. Sam Egwu, was granted a special interview on the state of affairs as regards the Academic Staff of Nigerian Universities (ASUU) industrial action that paralysed public universities in Nigeria. The NTA did not deem it necessary to invite any representative of ASUU or the 'striking' workers to the special interview session. This is clearly a lopsided news coverage and, to say the least, progovernment. There are several other instances of unbalanced reportage of news and the danger of such skewed, interest laced news reports is that they can unsettle the society. At another level, it is not uncommon in the Nigerian media clime to read in the pages of newspapers or hear or see on the radio and TV media irritants in matters of grave importance to society such as 'the official concerned was said to be unavailable as at the time of this news report', 'according to unconfirmed reports...', 'undisclosed sources say...', etc. These are all evasive stratagems that have increasingly made reading/listening to news in the Nigerian media boring and uninteresting. Media operators as well as 


\section{Osakue Stevenson Omoera}

journalists should realise that balanced reportage of news is not negotiable in any forward looking media culture.

The position of Skjerdal (2009) is instructive in the above regard. Reflecting on the East African socio-political environment, as well as a critical assessment of the media's own role in development, Skjerdal argues that the media should not just support the ruling class (party) in their reporting and commentaries. He further argues that if reporting is mainly seen as routine work with focus on news coverage and dissemination, then it is rightly a matter of knowing the practical skills. If, however, reporting is seen not only as dissemination, but also as involvement in the public discourse and active engagement in the cultural and national formation, then it becomes clearer that the journalistic craft or media practice involves more than simply knowing the techniques to be used in the editing room or conventional news media (newspapers, Internet, radio, television). This presupposes that the Nigerian media must engage in responsive and responsible practice that unearths hidden significant information on issues that concern the public for the greater good of the country. However, the greatest challenge in Nigeria and indeed in Africa is the inability of the media to live up to their social responsibility (Iredia 2004). This is the crux of the matter, which Nigerian media professionals must frontally address by refocusing their news agenda for national development. Again, putting in place certain support systems for Nigerian media professionals is critical to leveraging the fourth estate of the realm's catalytic role in ensuring growth and development in Nigeria.

\section{Support Systems for Nigerian Media Professionals: In lieu of Conclusion}

Although Omoera (2010b) has previously noted that the media have done much in consolidating the Nigeria's growing democracy, the use of freebies, 'coopting', death threats, craze for lucre, assaults, intimidations and fear of kidnapping and assassination of practising journalists have greatly weakened their ranks in the country. Therefore, emplacing certain support systems for media professionals can go a long way in assisting them to effectively serve as cornerstones of societal growth and development. This is more so because for development to come and be sustained, it must be in a peaceful atmosphere. 
And the functional imperatives of the media (information, entertainment, interpretation, transmission of values and linkage) are crucial to the maintenance of a culture of peace. Here lies the nexus between the media, peace and development. A relevant illustration of the critical role the media can play in putting societal issues in perspective and in the public domain is the recent increase in the pump price of premium motor spirit (PMS) by President Goodluck Jonathan that almost conflagrated Nigeria. The media, including, social networks were inundated with animated arguments for and against the removal of fuel subsidy. In the end, superior arguments, largely purveyed by the media in conjunction with the labour union, civil societies and the masses resulted in a 'compromise' to save the country from going under (Okhakhu and Omoera 2010b).

In spite of this, some kind of 'overhauling' is needed to make the Nigerian media more robust and development minded. First, the practice of media in Nigeria must be data-digital driven, wherein computer-assisted journalism will become the norm. Media operators and journalists must train and retrain as well as acquire the necessary facilities and competences to deploy information and communication technologies (ICTs) in their investigations, news reporting and analysis. Expectedly, Nigerian journalists should engage more in interpretational and investigative news reporting, drawing attention to critical areas such as rural integration and development, religious tolerance, environmental, gender, mental health, among other issues that a majority of Nigerians know little or nothing about. Structures should be put in place by both public and private media organizations to give journalists a sense of mission, commission and assurance that come what may their efforts can not be in vain. A situation where journalists are mercilessly beaten or incarcerated by security operatives under one pretext or the other should be discouraged. There are several instances where media professionals have been beaten/threatened/incarcerated by both known and unknown persons because of their even-handed coverage of burning national issues. The several threats to the lives of anchors of broadcast programmes such as Focus Nigeria on AIT network and Good Morning Show on Edo Broadcasting Radio, Benin City, and the recent incarceration of two print media journalists in Kaduna by the State Security Service (SSS) men are regrettable drawbacks to the agenda setting functioning of media professionals who by training are essentially progressive- 


\section{Osakue Stevenson Omoera}

minded people who are totally committed to the ideals of social progress, peace and stability of society.

Professional media bodies in Nigeria such as the Nigerian Union of Journalists (NUJ), Radio, Television and Theatre Workers Union (RATTAWU), the Institute of Mass Communication and Information Management of Nigeria (IMIM) must work in tandem to procure an effective insurance policy and welfare system for their members who constitute the bulk of practising media professionals in Nigeria. The thinking here is that with a solid welfare system in place, journalists can rest assure that in the event of any eventuality, their dependants will not suffer and as such they are likely to give their all in the line of duty. Media professionals deserve to be handsomely paid, inspired and motivated by media owners/governments or their employers, not just because of the ostensibly inclement climate of operation but because they are painstaking professionals worthy of attractive welfare packages. Importantly too is the need to maintain professional ethics without which Nigerian journalists may not be able to truly contribute to national development. Sobowale (2009) argues that at best journalism is not designed to make you feel good, but to tell you what you must know, whether you like it or not. Therefore, a situation where state councils of professional bodies such as NUJ are embroiled in mudslinging, corruption charges, internal squabbles, power tussles, among other antidevelopment activities should be avoided at all cost. The crises that have engulfed the Edo and Adamawa States' councils of NUJ in the last few years are a sad point of reference that should not be allowed to occur again.

In sum, the Nigerian media must reappraise their role since the coming into being of Nigeria as a nation and make necessary amends by learning from history. In this context, media professionals in Nigeria must strive to play the game according to the rules; ethics that guide the profession must not be sacrificed at whatever cost. It is worth reemphasizing too that practicing journalists in Nigeria must raise the ante in their interpretational and investigative news reporting activities to, among other things, sensitize Nigerians on national ideals and aspirations; encourage peaceful co-existence among the diverse peoples of Nigeria; awaken national consciousness on the need for security and loyalty to the nation; create the capacity and template for 
reasoned and critical judgment; and serve as unprejudiced agenda setters in the discussion of issues for an all round national development of the country. 


\section{Osakue Stevenson Omoera}

\section{REFERENCES}

Aisien, N. L., and F. Oriakhi. 2012. "The economics of fuel subsidy removal in Nigeria: A cost benefit analysis." The Constitution: A Journal of Constitutional Development 12(2): 12-28.

Abani, C., O. Igbuzor, and J. Moru. 2005. "Attaining the millennium development goals in Nigeria: Indicative progress and a call for action." In Another Nigeria is possible: proceedings of the first Nigerian social forum, edited by J. Moru, 1-13. Abuja: Nigerian Social Forum.

Adeseye, F., and E. Ibagere. 1999. Communication and man: A theoretical base for the student. Akure: Ola-Olu Enterprises.

Ahmad, G. I., and B. H. Ashara. 2009. "Reporting the environment: Challenges to the mass media." Reach: A Journal of the Institute of Mass Communication and Information Management of Nigeria 2 (1): 10-15.

Anyanwu, B. 2011. "Multilingualism and linguistic accommodation in Warri metropolis." Unpublished PhD Diss., University of Ibadan.

Anyanwu, B. 2012. "Multilingualism and language endangerment: the case of the indigenous Warri languages of Nigeria." Focus on Contemporary Issues 5(1): 76-91.

Babajo, A. K. 2008. "Literature in northern Nigeria: A comment on the role of small presses." Journal of Arts and Education 2(2): 48-54.

Banda, F. 2006. "Media in the service of citizens." Inaugural Press Freedom Day Public Lecture Series, Rhodes University, Grahamstown, South Africa, May, 03. Acessed 21 November, 2012: http://eprints.ru.ac.za/271/.

Baran, S. J. 2002. Introduction to mass communication: Media literacy and culture, Second Edition. Boston: McGraw-Hill Books Company.

Cabral, A. 1979. Unity and Struggle: Speeches and writings of Amilcar Cabral. New York: Monthly Review Press.

Campbell, R., C. Martin, and F. Bettina. 2007. Media and culture: An introduction to mass communication. New York: Bedford/St. Martin's Press.

Grimes, B. F., ed. 2000. Languages of the world. Dallas: Summer Institute of Linguistics. 
Hansford, K. J., J. Bendor-Samuel, and R. Stanford. 1976. "An index of Nigerian languages." Studies in Nigerian Languages 5: 1-24.

Haussman, R. 2012. "Product space and export competiveness." Paper presented at the Fourth Economic Policy and Fiscal Strategy Seminar, organised by the Center for the Study of the Economies of Africa (CSEA), Abuja, December.

Ibagere, E. 2009. Social development, television and politics in Nigeria. Ibadan: Kraft Books Limited.

Igbafe, P. A. 2006. "Before the axe falls: History and the humanities in our national life." First Valedictory lecture of the University of Benin, Benin City, August 10.

Iredia, T. 2004. "Public broadcasting in a developing nation: Focus on NTA." Contact: A Newsletter of the Nigerian Television Authority 1(2): 10-11.

McCombs, M., and D. Shaw. 1972. "The agenda setting function of the mass media." Public Opinion Quarterly 36 (2): 176-187.

Mgbejume, O. 1991. "Constraints on mass media policies in Nigeria." Africa Media Review 5(2): 47-57.

NIGERIA. 1999. The Constitution of the Federal Republic of Nigeria. Lagos: Federal Ministry of Information.

Okhakhu, M. A., and O. S. Omoera. 2010a. "Broadcasting and society: The question of functionality in the Nigerian Mediascape." Journal of Black and African Arts and Civilization 4(1): 71-86.

Okhakhu, M. A., and O. S. Omoera. 2010b. "Media as driver of development: Reflections on the Edo State, Nigeria experience." International Journal of Film, Literary and Media Studies 5-6(1-2): 12-22.

Omoera, O. S. 2010a. "Potentials of the television in reinventing the Nigerian tourism industry." Ekpoma Journal of Theatre and Media Arts 3(1-2): 115-128.

Omoera, O. S. 2010b. "The Import of the media in an emerging democracy: An evaluation of the Nigerian situation." Journal of Social Sciences 22(1): 33-38.

Omoera, O.S. 2013. "Bridging the gap: Answering the questions of crime, youth unemployment and poverty through film training in Benin, Nigeria." In The education of the filmmaker in Africa, the Middle East and the Americas, edited by M. Hjort, 39-57. New York: Palgrave Macmillan. 


\section{Osakue Stevenson Omoera}

Omoera, O. S., and P. Aihevba. 2012. "Broadcast media intervention in mental health challenge in Edo State, Nigeria." Antrocom: Online Journal of Anthropology 8(2): 439-452. Accessed December 17, 2012: http://www.antrocom.net/upload/sub/antrocom/080212/13-

Antrocom.pdf.

Omoera, O. S., and M. A. Okhakhu. In Press. "Political coverage in the Nigerian broadcast media: The need for professionalism." GANGA: Journal of Language and Literary Studies 5.

Onuoha, F. C. "Yet unanswered? The youth and gender questions in a decade of democratic governance in Nigeria." In A Decade of Redemocratisation in Nigeria: 1999-2009, edited by O. S. Ilufoye, O. A. Olutayo and J. Amzat, 173-181. Ibadan: Department of Political Science.

Onuoha, F. C. 2010. "Youth unemployment and poverty: Connections and concerns for national development." International Journal of Modern Political Economy 1(1): 115-136.

Onuoha, F. C. 2011. "Religious violence and the quest for democratic consolidation in Nigeria: 1999-2009." The Constitution: A Journal of Constitutional Development 11(3): 8-35.

Sambe, S. A. 2009. "News politics in Nigerian media: An appraisal." Reach: $A$ Journal of the Institute of Mass Communication and Information Management of Nigeria 2(1): 16-21.

Skjerdal, T. S. 2009. "Between journalism 'universals' and cultural particulars: Challenges facing the development of a journalism programme in an East African Context." Journal of African Media Studies 1(1): 23-34.

Sobowale, D. 2009. "FEC: Yar'Adua and the rubber stamps." Sunday Vanguard, June 21.

Ufuophu-Biri, E. 2006. The art of news reporting. Ibadan: Ibadan University Press.

Ugor, P .U. 2009. "Youth culture and the struggle for social space: The Nigerian video films." Published PhD Diss., University of Alberta. $\begin{array}{llll}\text { Accessed June, 2012: } & \end{array}$ http://birmingham.academia.edu/PaulUgor/Papers/583302/Youth cul ture_and the struggle_for_social_space_the_Nigerian_video_film. 
Ugulah, B. 2009. "Gender issues and the Nigerian mass media." Reach: A Journal of the Institute of Mass Communication and Information Management of Nigeria 2(1): 44-49.

Zhang, G., G. Shao, and N. D. Bowman. 2012. "What is most important for my country is not most important for me: Agenda-setting effects in China." Communication Research 39(5): 662-678. 


\section{ABSTRACT}

Employing the historical-analytic methodology, this study focuses on the news agenda in the Nigerian media. It sues that there is the need for news reporting and coverage activities of Nigerian media professionals to be redefined in order for them to be able to effectively contribute to sustainable peace in Nigeria, which is a sine qua non for development. In this context, this study examines the crucial role the media have been playing/ought to be playing/should be playing in the sustenance of peace and the galvanization of sustainable development in Nigeria as a microcosm of Africa. It specifically posits that the culture of peace can ensure the security of lives and properties in the Nigerian society and the society, in turn, stands a greater chance of being economically, socially, politically as well as culturally developed, if the agents of development such as the media and their operators/professionals diligently and dispassionately carry out their responsibilities. Towards this end, the media in Nigeria, both print and broadcast, is encouraged to engage in more interpretational and investigative reportage of issues for national development.

\section{KEYWORDS}

Nigerian Media; Sustainable Peace; National Development; Agenda Setting Theory. 



\section{NATIONAL ARMY AND STATE-BUILDING IN AFRICA: THE BRAZILIAN APPROACH IN THE CASE OF THE DEMOCRATIC REPUBLIC OF THE CONGO}

\section{Igor Castellano da Silva ${ }^{1}$ and José Miguel Quedi Martins ${ }^{2}$}

\section{Introduction}

This article aims to discuss the role of the technical cooperation, Brazil's participation in the peacekeeping missions and the international projection of Brazilian companies as elements that, once deliberately conjugated, can produce a particular model of international insertion of Brazil. It is understood that these three elements may be present, though in an embryonic way, in the case of the interaction between Brazil and the Democratic Republic of the Congo (DRC). Such interaction has the potential for assisting in the tasks regarding the formation of the National Army in the latter, something directly related to the difficulties that are present in the DRC and Sub-Saharan Africa in the state-building process.

The National Army is fairly recent, dating back to the nineteenth century, and is the fusing result of two historical accumulations: the Industrial

\footnotetext{
${ }^{1}$ Professor at the Universidade Federal de Santa Maria (UFSM) and PhD candidate at the International Strategic Studies Doctoral Program of the Universidade Federal do Rio Grande do Sul (UFRGS). Associate Researcher of the Brazilian Center for Strategy and International Relations (NERINT), the Center for International Studies on Government (CEGOV) and the South American Institute for Politics and Strategy (ISAPE). E-mail: igor.castellano@gmail.com.

${ }^{2}$ Professor at Universidade Federal do Rio Grande do Sul (UFRGS) and PhD in Political Science by the same institution. Associate Researcher of the Brazilian Center for Strategy and International Relations (NERINT), the Center for International Studies on Government (CEGOV) and the South American Institute for Politics and Strategy (ISAPE). E-mail: josemartins@ufrgs.br.
} 
Revolution and the political revolutions. In the case of the formation of SubSaharan Africa armies, the Africans were not able to benefit from any of these accumulations. First, because the system of African states emerged under the auspices of the UN Charter, which forbids using the war of aggression as an instrument of foreign policy. In addition, the regime of the Organization of African Unity gave stability to the national borders inherited from the colonial time (Herbst 1989; Herbst 2000). Second, because the political emancipation of the African countries was followed by a deliberate movement of the metropolises to conserve the dependence of their former colonies (neocolonialism). There would certainly be other countless elements to be inventoried. However, both elements here enrolled are enough to explain why, in the case of Africa, the National Army was not capable of structuring itself, bringing about the formation of the national economy through the means of defense, nor to establish the guardianship of order or to organize political participation, as it had happened in the cases of Europe and Latin America.

Moreover, under several different pretexts, Africans have been denied the military technology (which has civil production implications due to its dual technology) and political institutions (which usually result from the competition process between states and other forms of association). While early justifications came from Cold War ideological confrontation or neocolonialism, they now stem from the concept of human security and power-sharing ${ }^{3}$. But in both cases, although arguments are diametrically opposed, the profile of technical cooperation of central countries remains intact: they keep on denying access to technology and the right for Africans to engender their own history and institutions.

This text is divided into four major thematic parts. The first part investigates the historical role of the army in the construction process of states. Army's historical contribution went beyond its primary end (internal and external security); it also supported the formation of both economic

3 Power-sharing concerns political arrangements of distribution of power between contender groups. It can be applied as both a principle of political-electoral rules of democratic regimes and in processes of intrastate armed conflict resolution. This text focuses on the second case, in which the state sovereignty is clearly weakened and/or is little effective. 


\section{Igor Castellano da Silva and José Miguel Quedi Martins}

bureaucracy (productive capacity) and political institutions. After that, the different trajectory of the African armies is evaluated and discussed, in addition to their brief ascension and the reasons of their disruption upon the arrival of the 1990s. This phenomenon is related with the limits of the technical cooperation programs and the adoption of the human security concept.

The second part of the article argues how Africa's armed conflicts resolution only contributed to the continuity of this disruption process of the states. This occurred in various cases where palliative measures (peace negotiations based on power-sharing mechanisms) were privileged. Such mechanisms were privileged to the detriment of long-term resolutions, linked with the Security Sector Reform (SSR) process and the International Technical Cooperation (ITC) ${ }^{4}$.

The third part assesses the possibility of Brazil's contributing for the overcoming of this reality. It argues the hypothesis that there is a model, under construction, of international insertion that may offer more sustainable solutions to the African problems. In this sense, Brazil signals a new disposition to act in the conflict zones of the international system by means of a particular concept of human rights and the promotion of ITC programs.

The fourth part of this text focuses on a case study. It suggests that Brazil's embryonic model of international insertion could be tested in its relations with the DRC. It looks into the possibility of supplementing the role Brazil currently possesses in the pacification of the country, through the command of General Carlos Alberto dos Santos Cruz in the United Nations Organization Stabilization Mission in the Democratic Republic of the Congo

${ }^{4}$ ITC is a specific type of International Cooperation that composes the host of Official Development Assistance. It concerns a "cooperation centered in the exchange of technical and management knowledge, in order to increase the capacities of institutions and people to promote their own development" (Gutiérrez 2000). It is worth underscoring that there is a close relation between technical cooperation and development, since "the development process involves either new combinations of existing factors at a given technical level or the introduction of technical innovations" (Furtado 1961, 90). Further, ITC favors the construction of state capacities, inasmuch as "the crucial role of organizing the development effort is a state duty" (Souza 2005, 10). As the text will attempt to exemplify, the technical cooperation differentiates, however, in its form: from the vertical processes (inheriting the concept of international assistance between capitalist and developing countries) to the horizontal ones (projects between developing countries, therefore less asymmetrical). 
(MONUSCO). This participation could be extended to ITC programs in the security area, a sector where the partnership between both countries iscompared to other African cases-still scarce.

In conclusion, it recommends the possible creation of an institutional structure that guides and co-ordinates the Brazilian ITC, and that may organize the ministerial structure in order to guarantee the coherence between this cooperation and the guidelines of Brazil's foreign and security policy.

\section{The National Army in State-Building}

The army is the basic element of the coercive capacity of the states and was in the base of its historical creation. According to Robert Nisbet,

There is no known historical instance of a political state not founded in circumstances of war, not rooted in the distinctive disciplines of war. The state is indeed hardly more than the institutionalization of the war-making apparatus; its earliest function everywhere is exclusively military; its earliest rulers, generals and war lords. (Nisbet 1982, 103)

Charles Tilly aligns with this perception that the states were created as war camps in times of peace; that is, one of the different historical forms of organization and monopolization of violence (Tilly 1985, 171). Assuming a Weberian concept of state $^{5}$, this author claims it has three minimum, essential activities: the creation of the state (control of the territory), war making and protection (Tilly 1996, 158). It is understood, by logical association, the role of the National Army toward these activities.

However, the importance of the army is not limited to its ultimate activity (external and internal coercion). Its transformative capacity extrapolates (and it has historically done so) such function and intervenes in other correlate processes in state-building. There have been at least three activities in which the army has had its greatest importance: the formation of

5 The Weberian concept defines the state as a compulsory political organization that controls a territorial area where the bureaucracy successfully withholds the claim to the monopoly of the legitimate use of physical force in the enforcement of its order (Weber 2000, 525). 


\section{Igor Castellano da Silva and José Miguel Quedi Martins}

the bureaucracy, the incentive to the national economy (productive capacity) and the support to the development of citizenship and political institutions.

With respect to bureaucracy, the logic is clearer. The army is the most primitive example of bureaucracy created by the state, generating the first basic senses of order, hierarchy and rationality. Although its structure includes elements of the traditional and charismatic political domination, it is one the first organizations of the state to assume some sort of rationality - hierarchy, specialized knowledge and professional administration of violence (Luckham 1998, 21; Lasswell 1941). The military education in the National Armies was a basic factor in this process because, through the knowledge element, it relates directly to the formation of ranks for the bureaucracy ${ }^{6}$. Moreover, by means of the institution of the armies, there was a clear incentive from the state for the construction of bureaucracies related to extractive capacities, since it is important for the state to draw "from its subject population the means of state making, war making, and protection" (Tilly 1996, 158).

Concerning national economy, it matters to note that in a broad sense the military preparation influenced the economy (productive capacity), while the opposite is true as well, generating historical feedbacks. The army was always a construction instrument of the most basic infrastructural capacities of the state (public works and construction and maintenance of roads and communications system). Under the form of conscription, the advent of the National Army also rendered the base for education (literacy), formation and teaching of a body of future workers of the national economy.

Moreover, the technological development linked with the military use (necessities imposed by the competition of warfare) had always been in the

\footnotetext{
${ }^{6}$ The association between bureaucracy and knowledge is not new at all. Hegel had already associated the bureaucracy with the condition of "universal class" exactly for being the depositary of the technical scientific knowledge and the administrative practices of his time (Hegel 1997, para. 205). Not much differently, Weber associates bureaucracy with the accounting rationality and wordly asceticism, a characteristic of capitalism itself. The bureaucracy in Weber inherits the universal class of Hegel, since it is the depositary of not only knowledge, rather of very source of rationality, a characteristic of the correspondent form of administration, the only one that, for Weber, is capable of developing capitalism and practicing the (democratic) parliamentary government. If for Hegel bureaucracy appears as the bearer of knowledge, for Weber it becomes its source of production and reproduction as a social practice (Bendix 1986, 327-332).
} 
cutting edge of the technological transformations that led to the development of productive capacities. This rationale is well visible, at least since the permanent armies of the absolutism, which influenced through the military necessities (bronze cannon and gunpowder) new production technologies (bronze fusion and manufacture), though there are much older historical instances (McNeill 1984, 24-62). Further, related to this aspect and under initial pressure of the artillery innovations, war making became increasingly industrial, incorporating corps with these characteristics, the corps of engineers for instance (Engels 1981, 153).

In the core of these changes emerged the National Army, not simply as a war-making means, but rather as an instrument of assimilation, enthronement and dissemination of knowledge under the shape of technology. This, in turn, brings new productive capacities that improve the country's position in the international competition. The classic case is that of the United States of America (U.S.), which won the international competition not by fighting but allowing others to do it for them, while they were dedicated to the military preparation and the multiplication of productive capacities (Arrighi 1996, 38). In fact, in both world wars, which originated the U.S. hegemony, the country distinguished itself for supplying the victorious belligerents rather than for its campaigns. In this way, if the productive capacities matter for worldwide hegemony, they are certainly decisive to break through the delay of walls of underdevelopment and poverty from which the African countries suffer.

The role of the National Army is also relevant in the process of building citizenship and political institutions. It is known that a large part of the "revolutionary essence of the state" is in its capacity "to establish rights for segments of the population that had never had them" (Nisbet 1982, 109). The institute of conscription that based the emergence of the National Army is one of the parts that guarantee that this gear functions.

Long before the advent of the National Army, back in the fifteenthcentury Renaissance, when assessing the case of Rome, Machiavelli interprets the army as being a device of virtu, which can overdue and master the cunnings of fortune. Only the army of conscripts would ensure the empowerment of the peasants, who would be implicitly, by bearing weapons, qualified to enforce their rights - social reform and land concession (Maquiavel 1994). Likewise, Montesquieu, back in the Enlightenment eighteenth century, advocates for a 


\section{Igor Castellano da Silva and José Miguel Quedi Martins}

state of balance among the monarch, the noblemen and the people. The latter would be organized in a people's army based on conscription, in charge of public works and with political powers. Legal enforcement would be a duty of its. These popular army's officer corps would emanate from the troop (as the Germanic military democracy), who eats, sleeps and works with the people (Montesquieu 2002, 174). Both Machiavelli and Montesquieu had realized that the citizens' army was the path for building rights and political freedoms and the way to face patrimonialism.

Centuries later, Tilly argued that "the core of what we now call 'citizenship,' indeed, consists of multiple bargains hammered out by rulers and ruled in the course of their struggles over the means of state action, specially the making of war." (Tilly 1996, 164). For Giddens, "the nation-state and the mass army appear together, the twin tokes of citizenship within territorially bordered political communities." (Giddens 2001, 250)

There seems to be a common thread among the National Army, bureaucracy and political institutions (democracy). If "democracy advancement is the history of the state deprivatization" (Bresser-Pereira 1995, 87), the role of rationalizing politics (formation of the national bureaucracy) can be perceived as upholder and guarantor element of political freedoms. This sense is directly related with Dahl's perception that polyarchy presupposes guarantor institutions of the participation and competition rules (Dahl 1997, 27) and with that of Tilly (2007, 77-8, 164), who assumes that State Capacity is a precondition for democracy. For the latter, the process of building political institutions presupposes coercion capacities for "elimination or neutralization of autonomous, coercion-controlling power centers", which consists of one of the fundamental duties of the army (Tilly 2007, 78).

In sum, at the same time that one rejects the idea of "military-asregime" and its capacity as such of implementing stability, security and modernization (Luckham 1998, 26), one cannot deny the idea of "military-asinstitution" (National Army), capable of bringing economic, social and political benefits - in addition to being the basic source of the idea of security, defense and sovereignty. Nevertheless, the army's potential for contributing to the productive process and serving as base of the national (bureaucratic and political) institutions is hardly seen in regions such as Sub-Saharan Africa. 
There, the International Technical Cooperation does not seem to have yet reached its potential to contribute to the construction of National Armies.

\section{Army in Africa: beyond the coercive sphere}

This section discusses the role accomplished by the army in the Sub-Saharan Africa. First, it is necessary to answer to which extent the Sub-Saharan army differs from its counterparts around the world. It is worth acknowledging that, unlike others, the African armies were not the offspring of the Industrial Revolution nor national revolutions. It means they did not appear under the flow of technological transition that rendered the National Armies nor do they represent the institutionalization of political participation as a result of national revolution processes like those the U.S. and France underwent in the eighteenth and nineteenth centuries.

There are two aspects that must be underscored to explain, at least partly, this distinction. The African states system was created already under the auspices of the United Nations (UN) and the Organization of African Unity (OAU) systems, which explicitly condemn warfare as a device of foreign policy and guarantee the territorial sovereignty stability - borders (Herbst 1989, 6835). The situation in Sub-Saharan Africa differs reasonably from that of the Middle East, where warfare had, and might still have, a role in border redefinition. Second, as the political emancipations took place mostly in a controlled way to maintain metropolises' influence over their former colonies, there are rare cases of successful popular revolutions in Sub-Saharan Africa.

However, it does not mean war making is strange to Sub-Saharan Africa. On the contrary. Nonetheless, the pooling of the preceding factors led to the formation of a new type of war, based more on proxy forces than on the holding of conventional military capacities. The demand that this type of conflagration infringes is distinct in terms of scale. To foster guerilla warfare, or to fight them, light forces are enough, which do not justify even own production of ammunition, let alone weapons. It also does without combined arms, military schools, establishment of technical corps and everything else that is related to the national economy and bureaucracy.

It is a fact that the military achieved privileged ascension in African post-independence politics. It is due to their differentiated historical formation 


\section{Igor Castellano da Silva and José Miguel Quedi Martins}

and their importance as forces that could suppress the threats of disruption and secession of the new states (Hutchful and Bathily 1998, v-vii; Chazan et al. 1999, 13, 51). However, this ascension was marked by its ties with the neocolonialist structures and the rationale of the Cold War alliances (Tilly 1985, 186 $)^{7}$. The military ascension in politics was connected to the circulation of the elites and the training in military schools abroad, and resulted in military technical cooperation agreements with traditional powers. Such agreements were limited to the training and equipment purchase, without involving processes of technology transference or broader programs that could enable greater autonomy of the African armies and states.

Two elements were crucial for the deterioration of the army's role in the African states. First, in addition to the minimalist projects of military technical cooperation, it was the availability of foreign forces. Many times, these substituted for the local armies in the duties of external defense and internal security $^{8}$. The second element was the recurrent disruption of the Armed Forces by the rulers (generally, military) that aimed to keep their power base and establish the "formal monopoly on political power that tolerated no competitors" (Herbst 2000, 176). These competitors were often the very national military organizations. As a result, the political militarization in Africa became an "important ingredient in the decay of the state and the disintegration of the military institution itself" (Hutchful and Bathily 1998, iv). Military leaders, as Idi Amin (Uganda), Bokassa (Central African Republic), Siad Barre (Somalia) and Mobutu Sese Seko (Zaire, later the DRC), "who have laid waste to their bureaucratic machines in their pursuit of personal power, have in the end destroyed their very capacity to govern" (Luckham 1998, 26).

\footnotetext{
${ }^{7}$ Under this perspective, Benot stated, as far back as 1968, that "in total, the African armies took power in ten countries, but they kept it only in eight. In seven out of these eight countries the military dictatorship translates into a reinforcement of the neocolonialism" (Benot 1981, 89-90). The author claimed that "before any military coup took place, $[. .$.$] it was already known in Paris about such$ coups"; which resulted in the "signing of the military agreements with France that the ousted government had refused to sign" (Benot 1981, 77-8). This situation was analogous to those occurred with other Western powers, such as Great Britain and the United States.

${ }^{8}$ In the case of France, from 1960 to 1997, eight defense agreements and twenty-four technical and military assistance agreements were signed between the European country and the Africans. Still in the same period, thirty-four French military interventions took place in the continent, some of them using the service of mercenaries (Renou 2002, 10).
} 
As an aggravating factor, by the late 1980s, the adoption of neoliberalism by the third world countries involved significant cuts in government expenditures-which included, primarily, the military sector. Consequently, the African Armed Forces had their combat capacity drastically deteriorated upon the arrival of the 1990s (Thom 1995, 3). This situation favored the sprouting of warlords, directly linked with the informal economy that ascended due to the economic crisis (Luckham 1998, 15; Reno 1998, 4,12).

A generalized crisis of the African state coercive, extractive and administrative capacities was verified in the $1990 \mathrm{~s}$, possibly related to the disruption of National Armies. Adebajo recalls:

As the Cold War ended [...], the two superpower blocs [...] abandoned autocrats like Zaire's Mobutu Sese Seko, Somalia's Siad Barre, and Liberia's Samuel Doe who had served as reliable Cold War clients. Even as the foreign aid that sustained Cold War proxies in power was cut off, their trading networks came under increasing challenges from armed rebellions, which frequently replaced military coups as the main method for replacing sitting regimes. Economic reforms mandated by the World Bank and the International Monetary Fund (IMF) further eroded the control of African autocrats, urban riots and social instability accompanied enforced cuts in health and education and the removal of government subsidies on food and fuel. In an increasing number of states, African governments could no longer exercise normal state functions of providing security, order, and social services to their citizens, and lost control over the monopoly on violence and state bureaucracies. (Adebajo 2010, 25)

The human security ${ }^{9}$ concept popularization contributed to the process, by bringing the normative argument that the national armed forces of the developing countries had no relevant role to fulfill in terms of defense in a neoliberal and peaceful world (end of history). The human security concept contributes to two additional pernicious logics. The first was the loss of the

9 The human security concept opposes the collectivist approach of the national security or the state security. The former adopts the valuation of the micro (individual) level of threats. The content of security is widened and extends to the countless threats suffered by individuals, social groups and the nature. Critical analyses concerning this conceptual redefinition are made by Cepik (2001) and Ayoob (1995). 


\section{Igor Castellano da Silva and José Miguel Quedi Martins}

institutionalization mechanisms. The security focus became the imminent threats (securitization), acting in a palliative way. The value of institutionalized procedures of deliberation and governmental management of defense subjects was lost. The second pernicious logic was the loss of priority. The concept expanded the range of questions considered as matter of security. Thus, it changed the focus from the primary tasks of the states, as the establishment of the coercion monopoly (defense, security and protection), to other areas. Hence the range of necessary defensive and informational instruments in search of security increased (Cepik 2001). Graver still, the idea of contraposition between human rights and sovereignty/state capacity became popular, as if the state security itself did not involve, basically, the defense and protection of lives (Zacarias 1999, 13). In consequence,

In 1994, African countries had on average only 57 percent as many soldiers per thousand citizens as the average developing country (2 versus 3.5). [...]African governments cut defense spending disproportionately when they were forced to reduce spending. (Herbst 2000, 105)

Accordingly, in the 1990s, the difficulties in organizing armies in the African countries increased. The capacity of supporting the process of building the states, the national bureaucracy, the productive capacity and the political institutions was overcast. This situation was further worsened by the continent's armed conflicts that proliferated in this period. Since the lost decade (1980s), the economic liberalization has assisted in the reproduction of the poverty trap: a logic of double causality in which poverty generates conflicts and the conflicts generate poverty (Thomas 2008, 254). The 1990s signaled this process continuity and brought aggravating elements along. These are armed conflicts settlement mechanisms, aligned with the normativity of human security and based on the idea of power-sharing.

\section{Power-Sharing mechanisms: immediate and insufficient settlements}

This section discusses the limits of adopting power-sharing settlements for armed conflicts in Africa, for their pacification postponement and the reproduction of the difficulties in forming the armies within the state-building 
process in the region. Power-sharing mechanisms in conflict resolution processes are characterized by the distribution of power/ranks in the army, bureaucracy and political system among the belligerent groups.

There is a great debate in literature between those who believe that the negotiated peace (included in the category of power-sharing) is the best settlement for civil wars and those who claim that the military victory contributes more directly to peace sustainability. In the first case, in which one can find most analysts, policymakers and the international public opinion, the work of Matthew Hoddie and Caroline Hartzell should be cited (2003). The authors depart from the presupposition that, if power of voice is given to the old combatants in the political, economic and social directions of the country, the renewal of violence can be prevented. The authors conclude that, out of sixteen peace agreements signed from 1980 to 1996, those that had adopted the military power-sharing ${ }^{10}$ between the combatant groups had greater chances to keep the peace.

Opposing this vision, there are (i) critics to the power-sharing normativity as the conflict settlement instrument and (ii) the authors who claim that the military victory begets deeper post-conflict stability.

In the first case, Jack Snyder (2000) sustains that ethnic conflict settlements that consider pre-democratic identities as fixed may crystallize enemy and exclusivistic subnational identities, as well as existing divisions in the country. Collier and Sambanis (2005) claim that power-sharing arrangements imposed by foreign powers upon societies coming from conflicts are less likely to endure and render sustainable peace agreements. In Africa, moreover, Western efforts to build power-sharing peace agreements may encourage other rebel leaders to resurge seeking inclusion in similar agreements (Tull and Mehler 2005, 393).

Empirically, various power-sharing mechanisms for armed conflict settlements became indeed fragile elements for the conflict forces pacification in

10 Military power-sharing relates to the civil war settlements that operate through the "distribution of the state's coercive power among the combatant parties" (Hoddie and Hartzell 2003, 320). In practical terms, it concerns the "provisions allowing antagonists to remain armed or retain their own armed forces" (Jarstad 2006, 7). 


\section{Igor Castellano da Silva and José Miguel Quedi Martins}

the region. This phenomenon was observed in the First Liberian Civil War, Third Tuareg Rebellion, Casamance Conflict, Burundi Civil War and Fourth Tuareg Rebellion - in which significant post-conflict instabilities occurred. The First and Second Congo Wars also fit into such case, as it will be explained ahead (Arnold 2008, 65-69,208-217; Castellano da Silva 2012, 36-37).

In the second case (authors who defend the military victory in conflicts), Edward Luttwak (1999) and Robert Wagner (1993) sustain that allowing wars to reach their natural termination increases the likelihood of a lasting peace and an effective post-war reconstruction. Wagner argues for the deeper stability of civil wars ended by victories, rather than negotiated peace, due to the reduced capacity of the losing side to restart the armed conflict (Wagner 1993). One may say that these authors have history on their side. Roy Licklider demonstrates that, out of forty-six civil war cases that had been finished for more than five years, war recurred in $15 \%$ of the military-victory cases and in $50 \%$ of the negotiated-peace ones. That is, half of the analyzed civil wars that were settled by what we here call power-sharing restarted (Licklider 1995, 685). Paul Collier and Nicholas Sambanis (2005) demonstrated that, in $40 \%$ of the cases in which there is no military resolution of the conflict, war recurred within a decade. On the other hand, civil wars that ended in military victory are 2 to 3 times less likely to recur, since one of the parties is sufficiently dissuaded from resuming armed confrontation (Toft 2010; Wagner 1993; Regan 2002).

Out of the four wars with more than half million killed in Africa (First Sudanese Civil War, Nigerian Civil War, Second Sudanese Civil War and Second Congo War), only the war of Nigeria and Biafra (1967-1970) had a military victory to end the conflict. It might not be just coincidence that it was the only case featuring post-conflict stability in these large scale wars. The negotiated peace of the First Sudanese War (1956-1972) led to the Second War (1963-2005) and the current state collapse and implosion; and regarding the Second Congo War (1998-2003), the military victory absence engendered the nearly immediate recurrence of war (State of Violence). Nigeria's contrast to Congo and Sudan contributed to call into question the role of power-sharing.

At the boundaries of power-sharing as a conflict resolution tool, some alternatives arise and may integrate the Security Sector Reform (SSR), as an 
army formation element, and the possibilities of International Technical Cooperation (ITC).

\section{More sustainable solutions? Security Reform, Army and International Technical Cooperation}

In the context of settling African armed conflicts, SSR mechanisms, though marginalized, may contribute to post-conflict stability. As an instrument of armies' reconstruction, they may succeed through ITC.

Facing the debate presented in the previous section, Monica Toft (2010) proposes the resolution of the theoretical and empirical impasse over which is the most effective and desirable option (negotiated peace or military victory). She demonstrates that arguments for civil wars termination by negotiated peace take for granted that it reduces the number of fatalities compared with those of the military victory. There are, however, two faults in this logic of reduced fatalities. The first is that negotiated peace may serve as an opportunity for groups to recover and rearm-increasing the likelihood of deaths in the long term. The second problem concerns the idea that the lives supposedly saved by the negotiated peace will enjoy greater political and economic freedoms. According to the author, negotiated peace arrangements are related to higher authoritarianism levels in the long term-despite the tendency to democratization in the immediate aftermath. That occurs in that, on the one hand, opposition political groups arise and expand and, on the other hand, the government hardens its policies, based on the traumatic war memories, hoping to avoid new conflagrations. Furthermore, economic growth does not seem to be strongly linked with any specific type of conflict settlement any longer.

On the other hand, Toft (2010) evidences that military victory still brings very high costs, though relatively lower than those rendered by the negotiated peace in the long run. Both the negotiated peace and the military victory destroy lives, properties, cultural treasures; are more or less unstable; do not beget political freedoms in the long run; and do not necessarily produce the needed economic conditions for the country's rebuilding.

The resolution suggested for the impasse would be expanding the negotiated peace short-term lower-cost qualities into the long term. The adopted way would be the implementation of agreements that did not only 


\section{Igor Castellano da Silva and José Miguel Quedi Martins}

guarantee rights to the former combatants, rather used checks and balances (carrots and sticks). One of the practical manners for that is the provision, in the peace agreement itself, of practical means and methods to reset and reinstitutionalize the state security forces through the Security Sector Reform (SSR). Indeed, one of the negotiated peace shortcomings is the fact that the SSR theme generally rests in a peripheral position in the peace negotiations.

Lack of attention to SSR can have devastating consequences. Following negotiated settlements, for example, a military is left to fend for itself. What often follows is the reemergence of multiple sets of militaries/militias/rebel organizations ready to do the bidding of any political leader who can provide (or has provided) resources to sustain their vision of how to win. (Toft 2010,33)

Depending on its scope, SSR can bring the benefits of military victory into the negotiated peace structures, including those already established. That is because, while it guarantees the long-term dissolution of insurgent forces integrated in a power-sharing model, it institutes the state monopoly on coercive power and, thus, aims to block the intentions of resuming armed struggle by former insurgents and instituting it through new groups. It consolidates, in practice, state capacities as a precondition for the success of negotiated peace arrangements.

The SSR resolution may represent, depending on how each case develops, the very process of the National Army formation, which, as argued before, is capable of bringing various benefits for the state-(re)building. The case of Angola's civil conflict termination in 2002, for instance, demonstrated the capacity of National Army reform processes of bringing an end to armed conflicts. In this case, the peace agreements guaranteed the integrity of the national bureaucracy and army (Brown and Zahar 2008). It was about attributing a fundamental role in the pacification of war to the National Army.

It also depends on the profile of the ITC programs that sustain SSR: its scope, the technology transference character and the symmetry between the parties. At this point, it is worth discussing the potential that Brazil, which seems to be in a construction process of a particular international insertion model, has to contribute to this reality by through ITC programs that support army-building. This model seems to bind greater commitment to (i) the 
international order challenges, (ii) a particular perception of human rights, and (iii) the prioritization of South-South Cooperation through technical cooperation programs, as the following sections will discuss.

\section{The onus of the international order: rethinking Brazil's international insertion}

This section argues that Brazil's international insertion became in the last decade more aligned with ideas that collaborate with state-building in developing regions, such as Africa. Therefore, it can assist in the defining elements of both revolutions that led to the emergence of National Armies, namely the technical-productive capacity and the political institutions. The technical cooperation in broad areas (including military) can aid this process. Then, this section studies the case of the DRC and the current and future contributions that have been (and might yet be) generated by the Brazilian technical cooperation.

Brazil has been building in the last decade a particular model of international insertion that innovates in terms of contribution possibilities for the developing regions that suffer from severe armed conflicts. This model is based upon three complementary aspects, namely the international order onus enthronement, the authenticity proposal in international law and the SouthSouth solidarity.

Brazilian foreign policy current objective of collaborating to the reform of the multilateral institutions of governance involves the increasingly latent responsibility of bearing the onus of the international order. This responsibility has been adopted by the Brazilian diplomacy in the last decade, especially when it comes to the participation in peacekeeping missions of multilateral scope (Diniz 2006).

The UN Stabilization Mission in Haiti (MINUSTAH), established in 2004, was the milestone of this attitude. First, in quantitative terms, MINUSTAH has represented Brazil's most intense military effort in peacekeeping missions. Besides ensuring the change in the Brazilian effectives' profile in such missions - more troops than observers or police officers (Rezende $2013,172)$, the mission has historically been that with the highest number of Brazilian military. Second, in qualitative terms, the mission has involved Brazil's unprecedented commitment to the stabilization of countries in conflict, 


\section{Igor Castellano da Silva and José Miguel Quedi Martins}

taking the lead of a mission with responsibilities regulated by Chapter VII of the UN Charter (concerning missions with efforts of peace enforcement and use of force).

Moreover, Brazil's performance on the field has since involved military operations practical tasks. The situation evidences the acknowledgment that armed conflicts stability involves, in a complementary way, military tasks. This new commitment signed with peacekeeping missions, achieved in Haiti, was reaffirmed in the recent documents that comprise the Brazilian Defense normative framework. In its 2005 National Defense Policy and 2008 National Strategy of Defense (END, in Portuguese), the country adopts as one of its strategic guidelines,

To expand its projection into the world concert and reaffirm its commitment to the peace defense and cooperation among the peoples, Brazil shall intensify its participation in humanitarian and peacekeeping operations under the aegis of multilateral organizations. (BRASIL 2005a; BRASIL 2008a) ${ }^{11}$

\section{A new model for Brazil's international insertion? Authenticity in international} law

The Brazilian authenticity and normativity proposal towards international humanitarian law also points to the path of building a particular model for international insertion that has been toughened in recent years. It is possible to affirm that, since 1985, Brazil has adopted a particular perception in the human rights debates at multilateral fora. Its actions have, ever since, contributed to crafting an original and expanded concept of human rights that also includes elements that go beyond the idea of first-generation human rights

\footnotetext{
11 Such policy was institutionally achieved by the 2005 creation of the Brazilian Army's Peacekeeping Operations Instruction Center (CiOpPaz, in Portuguese) and deepened as of its transformation in 2010 into the Brazilian Peace Operations Joint Training Center (CCOPAB, in Portuguese), which gathers the Armed Forces, Military Police and Fire Department-adapting to the multidimensionality profile of the peacekeeping missions, as it will be shown later in this article (BRASIL 2012, 67).
} 
(liberal). It encompasses an additional central axis with the commitment to the right to development and health (access to medicines) ${ }^{12}$.

Brazil's action on human rights has continued and intensified, mainly regarding normativity. In this context, it is worth underscoring the Brazilian demarcation proposal concerning the Responsibility to Protect $(\mathrm{R} 2 \mathrm{P})$ concept, based on the creation of a new concept, namely the Responsibility while Protecting $\left(\mathrm{Rw}_{\mathrm{w}} \mathrm{P}\right)$. The $\mathrm{R} 2 \mathrm{P}$ concept resulted from the development of the notion of the right to intervene, emerging since the $1980 \mathrm{~s}$ in multilateral forums, consolidated in the documents of the sixtieth UN General Assembly (2005) on three pillars: (i) the responsibility of the states to protect their populations in cases of genocide, war crimes, ethnic cleansing and crimes against humanity; (ii) the task of the international community to encourage and help states exercise this responsibility; and (iii) the responsibility of the international community to act collectively, through the UN, in case the national authorities cease to protect their populations (MRE 2012b). For obvious reasons, Brazil has always feared the lack of major norm regulations, which became evident as of NATO's 2011 intervention in Libya's conflict, authorized by the UN Security Council under the R2P argument.

Given the abuses committed by NATO troops in the name of R2P (then used in an elastic way to change the regime), Brazilian government took a critical but proactive attitude, aligned with its recent stance in human rightsrelated foreign policy. President Dilma Rousseff suggested the adoption of the RwP concept, highlighting the responsibility of those in charge of peace

12 In the first case, the government sustained the "linking between human rights enjoyment and social welfare conditions reached by economic development" (Cervo and Bueno 2008, 467), being active in multilateral fora concerning the building of mechanisms to relief hunger and poverty and to promote employment and income. In the second case, it defended processes of social inclusion and pursuit of equity, by the strengthening of the countries' health systems. It defended the primacy of public health in the TRIPS negotiations at the WTO and had a leading role in the process that culminated in the 2006 creation of the International Purchase Facility for Drugs against HIV/AIDS, Malaria and Tuberculosis (UNITAID). More than that, as a developing country that had a successful democratic transition process, "Brazil has worked for the conceptual evolution of human rights and to breach the thematic cleavage that divides developing countries-as economic, social and cultural rights defenders - and developed ones - as civil and political rights promoters" (Amorim 2009, 70). 


\section{Igor Castellano da Silva and José Miguel Quedi Martins}

promotion tasks. In the opening statement of the 2011 General Assembly, President Dilma Rousseff sustained:

The world suffers today from the painful consequences of interventions that aggravated existing conflicts. They allowed terrorism to penetrate into places where it previously did not exist, gave rise to new cycles of violence and multiplied the number of civilian victims. Much is said about the responsibility to protect; yet we hear little about responsibility while protecting. These are concepts that we must develop together. (Rousseff 2011) ${ }^{13}$

It was an "invitation to a collective debate on the way of guaranteeing, when the use of force is considered as a justifiable alternative and is duly authorized by the Security Council, that its enforcement is responsible and legitimate" (MRE 2012b). Currently, the concept has gathered supporters and has potential for Brazilian diplomacy investments (Benner 2013, 39-44).

\section{South-South Solidarity: the role of interregional technical cooperation}

Concerning South-South Solidarity, Brazil has practiced it mainly through the International Technical Cooperation (ITC), and particularly within the scope of Technical Cooperation between Developing Countries (TCDC) ${ }^{14}$. ITC has

13 The basic principles Brazil then suggested for the RwP notion were as follows: (i) the primacy of the prevention and exhaustion of all peaceful means for the protection of civilians under threat of violence; (ii) the use of force must be authorized and limited in operational and temporal terms by the UNSC or GA and in legal terms by the international humanitarian law and international law of armed conflicts, producing stability under as little violence as possible (judicious and proportionate action, limited to the UNSC mandate); and (iii) the UNSC must be able to monitor, assess and ensure the accountability of those responsible for the use of force (UN 2011, 3-4).

${ }^{14}$ In the scope of South-South cooperation, TCDC is complementary to, yet essentially different from, vertical cooperation. The former involves less asymmetry, verticality and political cost to the recipient countries than what has been historically the case in the cooperation between central and peripheral countries. In light of the vertical technical assistance associated with the dependence reproduction (rather an instrument of neocolonialism), TCDC is the resulting movement for more horizontal ITC processes. Following the Bretton Woods system collapse in the 1970s, peripheral and semiperipheral countries sought the establishment of regulatory benchmark for TCDC and the strengthening of cooperation mechanisms. Notwithstanding, only after the 1990s neoliberal rule did emerging countries like Brazil, China and India begin to possess higher capital reserve and, then, be considered "key countries" by the UN High-level Committee on South-South Cooperation (Iglesias Puente 2010, 80). 
become a relevant instrument of Brazil's foreign policy, especially since it developed substantially in qualitative and quantitative terms in the 1990s.

In qualitative terms, it is worth highlighting ITC institutional restructuring and its centralization within the Ministry of Foreign Relations (MRE, in Portuguese). Brazil's ITC sector restructuring began with the establishment of the Brazilian Cooperation Agency (ABC) in 1987 (Decreto No. 94937/87). Though ABC first worked inside MRE's Alexandre Gusmão Foundation (FUNAG), it was expanded in 1996 and promoted to the status of an agency integrated directly under MRE's General-Secretariat (Decreto No. 2070/96). Increasingly important in Brazil's foreign policy, ITC ended up being "incorporated into the country's foreign policy as one of its permanent variables" (Cervo 1994, 37). By the 1980s, Brazil had advanced greatly concerning technical knowledge and was modifying ITC structures, from recipient to provider (TCDC), which gradually became ABC's main focus (Iglesias Puente 2010, 110-3).

In quantitative terms, the increase in project resources since 1998 is remarkable.

In the late 1990s Fernando Henrique Cardoso Administration, despite operational difficulties, increased TCDC actions and enlarged their scope, international geographic penetration and thematic areas, encompassing larger projects, especially in the professional training sector. (Iglesias Puente 2010, 111)

Starting in 1998, the projects grew and expanded, especially thanks to higher financial resources obtained together with the UNDP and as parliamentary amendment to the national budget, mainly to fund technical cooperation actions with the Community of Portuguese-Speaking Countries (CPLP) - the main action focus in Africa (Iglesias Puente 2010, 169). Besides, "since Lula Administration [...] TCDC activities have gained more emphasis due to instructions from MRE's Chief Office" (Iglesias Puente 2010, 113).

In this perspective Africa has become a more important Brazilian partner in TCDC. Since 1997, the continent has been the main destination for Brazil's TCDC resources, keeping an average higher than 50\% (Iglesias Puente 2010, 313; IPEA/ABC 2010, 57; IPEA/BM 2011, 46). In qualitative terms, Brazil has established long-term benefits cooperation with various African 


\section{Igor Castellano da Silva and José Miguel Quedi Martins}

countries. Brazil has created policies for (i) food security, opening up Embrapa offices in the continent; (ii) biofuels, with studies for the establishment in Africa of a productive unit of sugarcane articulated with an ethanol pilot-plant; (iii) agriculture development, mainly linked with cotton produce, with the implementation of model-farms in Mali, Burkina Faso, Chad and Benin; and (iv) public health, showing results with the opening, in Mozambique, of a Friocruz office and a plant of generic and antiretroviral drugs. General efforts for technical cooperation have generated agreements at the ministerial level within the Brazilian Cooperation Agency (ABC), Brazilian Trade and Investment Promotion Agency (APEX), Oswaldo Cruz Foundation (Fiocruz), Brazilian Company for Agricultural Research (Embrapa) and the Brazilian Industrial Development Agency (ABDI).

It is worth underscoring that the ITC in the African continent has ended up involving technical military cooperation programs-moving away even from the Portuguese-speaking axis in recent years. In the last decade, Brazil has signed technical cooperation agreements in the realm of defense with seven African countries (South Africa, Angola, Mozambique, Namibia, Equatorial Guinea, Nigeria and Senegal) and broadened its actions into four main areas. In military training, Brazil has expanded training supply to countries such as Guinea-Bissau (creation of the Security Forces Training Center, with Brazilian investment worth US\$ 3 million, establishment of the Brazilian Mission of Technical and Military Cooperation - MBCTM, and support of US\$ 750 thousand for SSR), Namibia (support for the creation of the Marine Corps, with approximately 600 military) and Benin (sending instructors to the Demining and Depollution Action Training Center). In the technical sphere, Brazil has supported Atlantic countries with the identification of the continental shelf (Namibia and Angola), besides carrying out joint technology development projects with South Africa (A-Darter air-to-air missile and dealings for the development of cargo aircraft, surface-to-air missile and UAVs). Within multilateral cooperation, the country has participated in the preparation of a common strategy for the CPLP oceans and integrated the relaunch of the South Atlantic Peace and Cooperation Zone (ZOPACAS), since 2005, creating four working groups, among which the one on "peace maintenance and peace supporting operations" (MRE 2011a; MRE 2011b, 92; Fellet and Kawaguti 
2013). In the context of military equipment, Brazil has sold patrol boats and ships for the Namibian Navy, six Super-Tucano aircrafts to Angola (and others to Senegal, Burkina Faso and Mauritania) and a Barroso class corvette to Equatorial Guinea. The country has made donations to the Namibian Navy, to the Coast Guard of São Tomé and Príncipe (four floats and 260 uniforms) and to the Armed Forces of Guinea-Bissau (uniforms).

Such projects can render mutual benefits by promoting political articulation in order to generate higher bargaining conditions and international institutions reform opportunities. This cooperation is clearly important as a means to sustain Brazilian industrial development (raw material sources and industrialized products consumer markets) and the incremental insertion possibility for Brazilian companies. It concerns tasks related to the structural challenges of qualifying exports and be favorably inserted in the technological transition (Martins 2013, 196). Though the possibility of gains is proper to ITC, it does not repeat the vertical profile of North-South cooperation. That is because it involves ample technology transference programs, knowledge and experiences exchange, and a process with no conditionality (opposed to the tied aid). In Africa, the presence in trade (exports) and of Brazilian companies (internationalization) followed these cooperation projects ${ }^{15}$, being concentrated, in the first case, on countries as South Africa, Nigeria and Angola, and, in the second case, in Angola, Mozambique, Guinea-Bissau and South Africa. Nevertheless, such presence is still restrict in figures, areas and companies, hence able to be expanded (IPEA/BM 2011, 88). In addition, this ITC effort remains as a discontinuous policy among different Brazilian state structures and agencies. The effectiveness of the ITC offered by Brazil to the African states still demands a qualitative coordination, linked directly with the Republic Presidency, which allows the best management and employment of these resources, incorporating ITC as a state policy.

Finally, after the Cold War there has been an increasing connection of the three aforementioned themes (peacekeeping operations, expansion of the

15 As a matter of fact, the flow of trade between Brazil and Africa increased more than $400 \%$ since the beginning of Lula administration, reaching the level of US\$26 billion in 2008 (PEB 2009). 


\section{Igor Castellano da Silva and José Miguel Quedi Martins}

human rights idea and ITC). In this sense, it is important to highlight the integrative role of peacekeeping operations that came to acquire multidimensionality and broader cooperation possibilities (UN 2003, 1; Bracey 2011, 322). Brazilian engagement in missions as UNAVEM III (Angola), UNTAET (East Timor), MINUSTAH (Haiti) and UNMIS (Sudan) has involved such profile of complexity and multidimensionality, and enabled the country to carry out, besides military and policing, civil protection and reconstruction actions, in the areas of health, education, agriculture, justice management, elections, sports and highway network recovery (Seitenfus 2008, 47-8). Such multidimensional character has been underscored by the Brazilian White Paper on National Defense (BRASIL 2012, 33).

More than internal stabilization mechanisms (incurring operational costs related to troops deployment), multidimensional peacekeeping operations have become mechanisms for the increase in technical cooperation programs. This furthers the possibility of long-term ties foundation and the emergence of business opportunities in the areas of construction, infrastructure and military equipment-promoting the internationalization process of Brazilian companies. In the case of Haiti, there have been many technical cooperation programs arising from the mission, including security, with bilateral efforts to organize a new security force in the Caribbean country. According to Brazil's Defense Ministry, the force shall have an army profile (not as a "president's personal militia"), committed and capable of dealing with the local security and defense issues (Portal Brasil 2012; Defesa Net 2012).

In sum, Brazil tries to regulate its new willingness to bear the onus of the international system by a human rights perception that underscores the commitment to development and sovereignty. Besides, the country aims to integrate within this scope medium- and long-term instruments that allow the strengthening of state capacities in crisis situations. This task may contribute to the case of the Democratic Republic of the Congo (DRC), a country that has suffered under one of the longest and deadliest Africa's armed conflicts, marked by the disruption of the army and the national state. 


\section{The case of the Congo: historical approximations}

After the attempt of Lumumba, who wanted a unitary and democratic Congo, being called into question by an intervention of a U.S.-subject UN, never again has this country, harassed and sold, deprived of its best rulers and featuring a large number of political parties though not a truly national political organization, been able to find, for a single moment its unity and balance. (Benot 1981, 79)

Congo's decolonization crisis (1960) led to the ascension of military trained and financed by the West (the U.S. and Belgium) in 1965. General Mobutu Sese Seko's regime resorted to nationality and implemented the plan of turning the country, then the second African economy, into an "African Brazil". The project involved the strengthening of the National Army and the establishment of military schools. These, with the support of technical cooperation programs with the U.S., France and Belgium, ended up becoming a center of excellence in the continent.

However, the cooperation agreements were restricted to the military area (with no public services and education) and did not involve the transference of technology and productive capacities. Moreover, disputes between military groups for the political power led the president to a deleterious cycle of personalization of power in the mid-1970s. Mobutu suppressed possible competing forces within the army and gave out policies of theft of national wealth and deconstruction of the state capacities. The situation engendered not only the political and economic crisis (worsened by the foreign debt and neoliberal reforms) but also the scrapping of the Army (reduced to twenty thousand men to defend then second largest country in the Sub-Saharan Africa) and the national coercive capacity.

By the $1990 \mathrm{~s}$, this reality, added to the regional interstate rivalry, and by the strategic/economic role of the region, led to a severe cycle of armed conflicts that resulted in the fall of Mobutu, the rise of Laurent Kabila (backed by Uganda, Rwanda and Burundi) and the attempt of his ouster by part of his supporters in what became known as the Second Congo War, or the Great War of Africa (the deadliest conflict since World War II). The solution for the complex armed conflict that involved nine countries and various interstate 


\section{Igor Castellano da Silva and José Miguel Quedi Martins}

armed groups was the mechanism of power-sharing and integrating the combatant forces.

However, since 2003, the conflict's formal end has not resulted in its pacification. Groups dating back to the Second Congo War have not yet been disarmed (FDLR) ${ }^{16}$, new groups have entered into Congolese territory-which lacks protection (LRA, ADF $)^{17}$ - and other already integrated groups have risen again from the core of the armed forces, seeking political gains (CNDP and the recent M23) ${ }^{18}$. The local UN mission, in act since 1999 (MONUC then, MONUSCO now), has sought to contribute to the stabilization of the bellicose region of eastern Congo and support, along with other sponsors, the processes of building national institutions (elections) and reforming the security sector (army, police and judiciary).

However, the new Armed Forces of the DRC (FARDC, in French) have been throughout the period unable to suppress the armed groups and establish internal and external security (since some of the armed groups are funded by neighboring countries and foreign organizations). An emblematic moment occurred in November 2012, when neither the FARDC nor MONUSCO (since 2003 the largest UN peacekeeping mission) was able to cope with the occupation of Nord Kivu's capital, Goma, by the M23. The controversy has generated international pressure to establish a force of offensive intervention that would act more incisively in the support of disarming the groups operating in the eastern DRC.

\section{Brazil fights in the Congo: the role of General Cruz}

Thus was created in March 2013 the Force Intervention Brigade (FIB). The importance of FIB to Brazil is central. As of FIB's establishment in April, its command, as well as MONUSCO's, was handed to Brazilian Divisional General Carlos Alberto dos Santos Cruz. The general's credibility derives precisely from the work he conducted as MINUSTAH's commander between

\footnotetext{
${ }^{16}$ Forces Démocratiques de Libération du Rwanda (Democratic Forces for the Liberation of Rwanda).

${ }^{17}$ Lord's Resistance Army and Allied Democratic Forces, respectively.

18 Congrès National pour la Défense du Peuple (National Congress for the Defense of the People) and Mouvement du 23-Mars (March 23 Movement), respectively.
} 
2006 and 2009 and the experience the Brazilian army has carried in coping with irregular threats, especially in complex environments (like the jungle).

FIB features important particularities. It operates with more than three thousand men from South Africa, Tanzania and Malawi. They are deployed in Goma under the direct command of MONUSCO Force Commander (General Cruz), divided into three infantry battalions, one artillery unit, one Special Forces unit and a reconnaissance company, and feature new South African military equipment (e.g. Oryx helicopters). FIB has a one-year mandate (resolution 2098 of 28 March 2013) to conduct offensive operations either unilaterally or jointly with the FARDC (UN 2013). The main objective is to prevent the expansion of all armed groups in the eastern Congo (so-called negative forces), neutralize and disarm them (paragraph 12-b). After the resolution publication, commentators argued it was UN's first offensive combat force. Despite a number of missions based on Chapter VII of the UN Charter since its foundation, indeed, such a clear mandate is unprecedented by explicitly mentioning offensive operations against insurgent forces.

The performance of the Brazilian general was incisive already in the operation's first months. After offensives started on October 25, joint combat operations with the FARDC (80 km north of Goma), at the same time as negotiations developed at the International Conference on the Great Lakes Region in Kampala, led the M23 group to surrender on November 5, 2013 (Mail \& Guardian 2013a; Mail \& Guardian 2013b). Thus, FIB has acted in an exemplary manner and contributed to foster stabilization hopes in the eastern Congo.

It is important to ask, however, what will come after FIB? At this point, the importance of reconstructing the National Army in the country emerges. The current SSR projects are too atomized and their programs are disconnected from the social role of the National Army.

There are several processes of DRC's Security Sector Reform (SSR) whose aim is the country's autonomy in carrying out internal and external security (defense) and, more important, dissuading the actions of armed groups. As a matter of fact, the UN resolution that established FIB underscores the necessity of the DRC to create a Rapid Reaction Force to take on, in the future, FIB's current duties. However, such SSR projects, besides having to cope with a force composed of various rebel groups that were integrated into the army 


\section{Igor Castellano da Silva and José Miguel Quedi Martins}

over time, have several flaws. Mainly for representing atomized programs and actions in different fronts (various sponsors), they end up not contributing to the emergence of cohesive security forces in terms of command and control (C2), unity and doctrine. In practice, the FARDC were eventually a destabilization factor for the country, with battalions acting in an autonomous way and being an instrument of aggression against local populations and of illegal exploitation of natural resources. Projects that could be implemented include broader, structural cases for making a National Army that is source of identity among the population, of training for the incipient bureaucracy and of employment and income alternative. Brazil could, in fact, contribute to this process. In this sense, the possibility of expanding the Brazilian action in the country could be very fruitful. To make it possible, however, it seems imperative that the decentralization process of the military and civil technical cooperation be subject to a supraministerial governing body for these policies.

\section{Brazil and the DRC: historical partnership and current possibilities}

The relations between Brazil and the DRC are vital for Brazil's African foreign policy - which has increasingly acquired centrality in the country's SouthSouth policy in the last decade ${ }^{19}$. The Congo relates to the three priority cores that have demonstrated continuity in the Brazilian partnership with Africa since the 1960s, namely the Portuguese-speaking countries, the Southern Africa and the South Atlantic regions. Concerning the first core, the DRC is Angola's neighbor and priority in the country's foreign and security policy (bearing in mind Angola's constant participation in the DRC's armed conflicts since 1997, besides being one of the major stability guarantors in Kinshasa since 1998). Regarding the second core, it is important that Central Africa Great Lakes conflicts became part of the security scope of the entire Southern Africa, since the DRC's inclusion in the SADC, this organization's intervention in support of Laurent Kabila, and the active participation of South Africa since 2002 for the

${ }^{19}$ For further analyses on Brazil's African policy, please refer to Visentini (2010; 2011), IPEA/BM (2011), Saraiva (1996; 2010), Rodrigues (1964) and Ribeiro (2007). 
peace and reconstruction of the DRC (South Africa is today FIB's main leader). Within the third core, the DRC is formally part of the ZOPACAS, whose relevance is central to Brazil's foreign and defense policy, since the latter considers "its projection through South Atlantic boundary and the bordering countries of Africa" as its strategic environment (BRASIL 2005a; Oliveira 2013, $22)$.

As an example of importance, Brazil recognized the independence of then République du Congo on August 17, 1960, and soon after began considering it a key country to Brazil's foreign policy. This occurred mainly within the UN - when Brazil played a major role in UN's first mission in the country (United Nations Operation in the Congo - ONUC, in effect from July 1960 to June 1964). Almost 200 officers from the Brazilian Air Force (FAB) were deployed, who acted in real warfare situations, seeking to ensure the sovereignty and selfdetermination of Lumumba's government.

Concerning Brazil-DRC recent relations, after the Brazilian Embassy in Kinshasa was closed in 1997 and Brazil's omission regarding both wars in the South Atlantic country, the emergence of Lula administration enabled the reestablishment of the country's mission (with the embassy reopening in 2004) and the increase in bilateral cooperation (projects in the areas of health, standardization, agroecology and family farming, coffee growing, human resources training, cooperation between diplomatic academies, and culture).

In the security sphere, with an important precedent (Brazil's participation in the $\mathrm{ONUC}$ ), there was recently the rapprochement attempt between both countries and Brazil-Congo ties have acquired an unprecedented character. It is worth pointing out that this very rapprochement in the twentyfirst century was first instituted within the security scope. Even before Lula's first trip to Africa in November 2003 and the missions that resulted in the reopening of the embassy in Kinshasa, Brazil had contributed with two C-130 Hercules transport aircraft and crew for UN's Interim Emergency Multinational Force (IEMF) in Bunia (Legislative Decree N. 328, 2 July 2003). The aircraft contributed to IEMF's logistic capacity (transport of troops and equipment) in support of MONUC's Uruguayan battalion. They were integrated into the force on July 8 under the coordination of Brazil's and France's Defense Ministries (MRE 2003, 272). 


\section{Igor Castellano da Silva and José Miguel Quedi Martins}

Moreover, thenceforth, the Brazilian government has issued in a constant basis notes and statements about the serious situation in the DRC, which demonstrated an unprecedented concern ${ }^{20}$. Such statements had their milestone in 2010, when the Ministry of External Relations issued, on September 6, a note condemning the mass rape of women and children by rebels in the eastern Congo between July 30 and August 3 (MRE 2010a; MRE 2010b). The note had a more practical effect in late October, when the Brazilian government provided humanitarian assistance worth US\$ 1 million in donations to the DRC, through the UN Office of the High Commissioner for Human Rights (OHCHR). The pioneer humanitarian aid sought to reinforce the "mechanisms for reparations and access to justice for victims of sexual violence in the country" (MRE 2010b).

Bearing in mind the symbolic relevance of Brazil in the Congo's pacification process (the command of the first operation that led a relevant armed group to surrender since 2009), Brazil's possibilities for action in projects involving medium- and long-term reforms in the security sector (even counting on Angola's partnership ${ }^{21}$ ) may bring mutual benefits in both sides of the Atlantic. In the case of the Congo, it is worth underscoring the possibility of support by (Brazilian) Armed Forces structured within the logic of an army of citizens, which has always guaranteed services that go beyond defense and security. Brazil sees the possibility of a further step in the implementation of its insertion model into developing regions marked by armed conflicts, strengthening itself and its presence in the South Atlantic, in cooperation with the neighboring countries as "a force for peace, stability and prosperity in its own region and even beyond it" (Rousseff 2011). This presence could even support the increase in trade links and the industrialization process of Brazilian companies for the African continent ${ }^{22}$. This opportunity can help increase the

${ }^{20}$ For instance, throughout 2004, the Ministry issued notes of concern and support for the DRC in the speeches of President Lula in events linked with Africa (MRE 2004a, 347; MRE 2004b, 333).

${ }^{21}$ Until recently, Brazil and Angola had acted together in the efforts of stabilization in Guinea-Bissau and the reforms in defense and security sectors, especially through the ECOWAS-CPLP Road Map to the Defense and Security Sector Reform of the country (MRE 2011b, 90; MRE 2012a, 131).

${ }^{22}$ Public and private companies have been increasing since the 1980 s their participation in the continent, mainly in infrastructure, energy and mining sectors. These traditional agents (Andrade Gutierrez, Camargo Correa, Odebrecht, Petrobras, Queiroz Galvão and Vale) have contributed, with the support 
industrialized products participation in Brazil's exports ${ }^{23}$ and diversify trade sources and investments for the African partners.

Nevertheless, in the security sector, the Brazilian government initiatives went along with the characteristic atomization of most international initiatives for the DRC and were marked by short-term solutions. In fact, there were significant and unprecedented Brazilian efforts and repeated manifestation of MONUC's importance for the country's stabilization and of the perception that there is a direct relationship between the current reality and the difficulties in the process of building a National Army - responsible for the "insubordination of some armed groups and the still manifest tensions" (BRASIL 2005b, 5). However, Brazil-DRC cooperation has not been established as a priority in security-related areas-as Technical and Military Cooperation or clearer efforts within the UN. Although it has been signaled during the period the cooperation in the areas of infrastructure (which would cooperate in DRC's current logistic challenges) and restructuring of the national economy (which would provide opportunities for the populations seeking to break away from the cycle of armed conflicts), there have not been more structural initiatives from Brazil in the security sector that act directly in the stabilization of the war in the country. This situation seems to adjourn the Brazilian objective of "guaranteeing that South Atlantic and the South American and African continental areas are zones of peace and prosperity" (Oliveira 2009, 31). Accomplishing such tasks, raised by the newfound

of the Brazilian government, for hiring local labor (an alternative for employment and income) and for the development of capacities (training) (IPEA/BM 2011, 87). There is, however, a large concentration of Brazilian presence in the activities of these companies (the Marcopolo company could also be included here). Although APEX undertakes efforts to support foreign trade and internationalization of Brazilian companies, and the construction of a "favorable business environment in Africa", there are still few cases of internationalization of small- and medium-sized Brazilian companies in the African continent (IPEA/BM 2011, 91).

${ }^{23}$ Brazilian exports to African countries are characterized by the predominance of manufactured goods, accounting for $80 \%$ of exports in 2010 (IPEA/BM 2011, 96). This scenario differs from the reprimarization process of the Brazilian exports, which started with the commercial liberalization in the 1990s and had a milestone in 2008 as the values of basic and semi-finished products (US\$ 100 billion) surpassed those of manufactured products (US\$ 92 billion) in the exports of Brazil (IPEA 2013). 


\section{Igor Castellano da Silva and José Miguel Quedi Martins}

international protagonism of Brazil, seems to require a redesign of its contents in the structure of the state and the Federal Public Administration.

\section{Final Considerations}

This article discussed the role of the army and conflict settlement mechanisms in the incipient process of building the African states. The poor building of the African armies and the continuity of fragile settlement of armed conflicts reflect a reality marked by social, political and security challenges related to the absence of state capacities. This situation has gained increasing attention in Brazil, mainly due to the centrality of Africa in the Brazilian foreign policy in the last decade.

The aim was to address, preliminarily, the possibility of a particularly Brazilian embryonic model of international insertion based on the concatenation of three spheres: coercion, production and institutions. These three elements are directly related to the benefits arising from the process of building the National Armies. In the particular case of the DRC, besides Brazil's participation in MONUSCO, International Technical Cooperation (ITC) may favor these processes. In this case, the Brazilian participation in the command of the UN mission is significant and changes the balance of power toward the long-delayed conflict pacification. Moreover, in the long term, the international technical partnerships will matter more than the power projection or military deployment in the name of international order. Gradually, the international order assimilates the idea that security issues, similarly to internal order, cannot have just a military or police response.

The technical cooperation is not important to Africa and the DRC only. ITC matters to Brazil in order to ensure scale for the military-academicindustrial complex, for which South America itself is insufficient. In this case, the interregional relations in the south-south axis, where the role of African countries is highlighted, become essential. The interregional partnership is transformed into an instrument for the consolidation of regional integration objectives, particularly, the construction of the Defense Industrial Base.

Certainly, a number of questions remain open, ranging from more abstract aspects (understanding of the current role and function of the state) to 
the materialization of an associate management among national and local governments, UN peacekeeping forces and companies. In the first case, there should be further studies able to better elucidate the relation between the national state and the eventual advent of the region state or the possibility, as van Creveld points out $(2004,595)$, of other government mechanisms rather than the state. In addition, it is quite thought-provoking to study the possibility for mechanisms similar to those in Brazilian Federal Law $11.107 / 2005$ (which regulates public consortia) to be adopted in countries that are subject to UN interventions, generating consortia that can improve the cooperation among the UN, national and subnational governments, and companies.

Meanwhile, in order to optimize a decentralized technical cooperation, in administrative terms, there should be a political centralization mechanism able to articulate the action in foreign policy with the necessary domestic interministerial articulation in Brazil. Furthermore, for Brazil's international projection, it is necessary to consider conjugating the organized civil society, Brazilian companies (private sector), subnational entities such as state and municipal governments (public sector), and the third sector itself ${ }^{24}$. This requires a redefinition of roles of the National Defense Council and the constitution of a political operator, capable of combining the public consortia internally with the International Technical Cooperation. In the U.S., the interministerial action has long been articulated with ITC thanks to the issuing, in 1950, of the NSC 68 report (National Security Council Report 68: United States Objectives and Programs for National Security). In light of the globalization, the U.S. itself understands the contingency of reorganizing such effort for the state complexity in the information age and discusses its reediting, as "NSC 68 the second". This position may be called International Security Advisor. However, more than a position, it is about creating a mechanism to

${ }^{24}$ One of the possible paths for this combination could be the Union Houses. They are the result of a formulation emerged in the Union Houses Seminars, promoted by the ISAPE (South American Institute for Policy and Strategy), of which we authors are part. The main goal of the Union Houses is to promote a specialized structure for the formation of public partnerships and consortia, both combining federal, state and municipal governments, and combining the Federal Entities and the private initiative. The aim is promoting national development and expanding public services. 


\section{Igor Castellano da Silva and José Miguel Quedi Martins}

associate the National Strategy of Defense - END - (BRASIL 2008a), important for having the technological basis for the country's development pattern, with the economic growth strategy of the Growth Acceleration Programs (PAC), placing the END agenda in the center of the transition from a consumption-based growth model to another model based on development. Only then will the President have the mechanism to fulfill his or her institutional mission of, effectively, coordinating the security and foreign policy concerning both national mobilization - Decree N. 6592/2008 (BRASIL 2008b) - and ITC.

After this political centralization mechanism, the decentralized technical cooperation could indeed contribute to this process, including Brazilian states and municipalities within the logic of cooperating with developing countries and organizing the participation of small- and mediumsized companies in a business model in services that take into account the ethical content of cooperation. This possibility has gained constant regulation efforts by the federal government and the federated entities (SAF-SRI 2013). An advancement in this sense was the statement in the South-South Decentralized Technical Cooperation Program (2012), established by the Federative Affairs Division of the Secretariat for Institutional Relations (SAF/SRI) and ABC, that "private sector institutions, non-governmental organizations, universities, sponsoring agencies, and both Brazilian and foreign international organizations will be able to take part in the projects as associate/secondary entities [...]" (SAF-SRI/ABC 2012, 3). This may serve as a trigger for a benchmark in regulating the establishment of public consortia of international operations aiming to integrate the state (at its different levels), society, market and academia within projects to promote development.

In sum, just as the National Army existed in the imagination and work of Machiavelli and Montesquieu centuries before coming to existence in the nineteenth century, Brazil's international insertion model might derive from a combination of Brazilian military and diplomatic experience abroad and the artifice of human consciousness that seeks to find generalities and define within the associate management a way of converging its distinct practical aspects (ITC, participation in UN peacekeeping operations and foreign projection of 
companies). Albeit in a limited way, as Demiurge, consciousness has the potential to create reality. 


\section{Igor Castellano da Silva and José Miguel Quedi Martins}

\section{REFERENCES}

Adebajo, Adekeye. 2010. The Curse of Berlin: Africa after the Cold War. Scottsville: University of KwaZulu-Natal Press.

Amorim, Celso. 2009. "O Brasil e os Direitos Humanos: em Busca de uma Agenda Positiva." Política Externa 18(2): 67-75.

Arnold, Guy. 2008. Historical Dictionary of Civil Wars in Africa. Second Edition. Lanham: Scarecrow Press.

Arrighi, Giovanni. 1996. O Longo Século XX. Rio de Janeiro: Contraponto.

Ayoob, Mohammed. 1995. The Third World Security Predicament: State Making,

Regional Conflict, and the International System. Boulder: Lynne Rienner Publishers.

Bendix, Reinhard. 1986. Max Weber: Um Perfil Intelectual. Brasília: Editora da Universidade de Brasília.

Benner, Thorsten. 2013. “O Brasil Como Um Empreendedor Normativo: A Responsabilidade Ao Proteger." Política Externa 21(4): 35-46.

Benot, Yves. 1981. Ideologias Das Independências Africanas - Vol. 2. Second Edition. Lisboa: Livraria Sá da Costa Editora.

Bracey, Djuan. 2011. “O Brasil e as Operações de Manutenção da Paz da ONU: Os Casos do Timor Leste e Haiti." Contexto Internacional 33(2): 315331.

BRASIL. 2005a. Política de Defesa Nacional (Decreto No. 5.484). Brasília: Presidência da República.

BRASIL. 2005b. Mensagem No. 121 de 2005. Brasília: Senado Federal. Secretaria Especial de Editoração e Publicações do Senado Federal.

BRASIL. 2008a. Estratégia Nacional de Defesa (Decreto No. 6.703). Brasília: Presidência da República.

BRASIL. 2008b. Sistema Nacional de Mobilização (Decreto No. 6.592). Brasília: Presidência da República.

BRASIL. 2012. Livro Branco da Defesa Nacional. Brasília: Presidência da República.

Bresser-Pereira, Luiz Carlos. 1995. "Estado, Sociedade Civil e Legitimidade Democrática." Lua Nova-Revista de Cultura e Política (36): 85-104.

Brown, Stephen, and Marie-Joëlle Zahar. 2008. "Committing to Peace: Soft Guarantees and Alternative Approaches to Power Sharing in Angola 
and Mozambique." Journal of Peacebuilding \& Development 4(2): 7588.

Castellano da Silva, Igor. 2012. Congo, a Guerra Mundial Africana: Conflitos Armados, Construção do Estado e Alternativas para a Paz. Porto Alegre: Leitura XXI.

Cepik, Marco. 2001. "Segurança Nacional e Segurança Humana: Problemas Conceituais e Conseqüências Políticas." Security and Defense Studies Review 1(Spring): 1-19.

Cervo, Amado Luiz. 1994. "Socializando o Desenvolvimento: Uma História da Cooperação Técnica Internacional do Brasil." Revista Brasileira de Política Internacional 37(1): 37-63.

Cervo, Amado Luiz, and Clodoaldo Bueno. 2008. História da Política Exterior do Brasil. Third Edition. Brasília: Editora da Universidade de Brasília.

Chazan, Noami, Peter Lewis, Robert Mortimer, Donald Rothchild, and Stephen John Stedman. 1999. Politics and Society in Contemporary Africa. Boulder: Palgrave Macmillan.

Collier, Paul, and Nicholas Sambanis, eds. 2005. Understanding Civil War: Evidence and Analysis - Vol. 1, Africa. Washington, D.C.: The World Bank.

Dahl, Robert. 1997. Poliarquia. São Paulo: Editora da Universidade de São Paulo.

Diniz, Eugenio. 2006. "O Brasil e as Operações de Paz." In Relações Internacionais do Brasil - Temas e Agendas, edited by Henrique Altemani e Antônio Carlos Lessa, 303-337. São Paulo: Saraiva.

Defesa Net. 2012. "HAITI - Brasil Deverá Cooperar na Estruturação de Novas Forças de Defesa." July 26. Accessed February 06, 2014. http://www.defesanet.com.br/ph/noticia/6967/HAITI---Brasil-deveracooperar-na-estruturacao-de-novas-forcas-de-defesa.

Engels, Friedrich. 1981. "O Papel da Violência na História." In Escritos Militares, edited by Karl Marx, Friedrich Engels, and Vladimir Ilitch Lenin, 151-160. São Paulo: Global Editora.

Fellet, João, and Luis Kawaguti. 2013. "Contra Pirataria, Brasil Expande Ação Naval na África." BBC Brasil, May 16. Accessed February 07, 2014. http://www.bbc.co.uk/portuguese/noticias/2013/05/130513 pirataria a frica brasil jf lk.shtml. 


\section{Igor Castellano da Silva and José Miguel Quedi Martins}

Furtado, Celso. 1961. Desenvolvimento e Subdesenvolvimento. Rio de Janeiro: Fundo de Cultura.

Giddens, Anthony. 2001. O Estado-Nação e a Violência: Segundo Volume de uma Crítica Contemporânea ao Materialismo Histórico. São Paulo: Editora da Universidade de São Paulo.

Gutiérrez, Jorge. 2000. "Cooperação Técnica." In Diccionario de Acción Humanitaria y Cooperación al Desarrollo, edited by Karlos Pérez de Armiño. Acesso em 05 de fevereiro de 2014: http://www.dicc.hegoa.ehu.es/listar/mostrar/45.

Hegel, Georg Wilhelm Friedrich. 1997. Princípios da Filosofia do Direito. São Paulo: Martins Fontes.

Herbst, Jeffrey. 1989. "The Creation and Maintenance of National Boundaries in Africa." International Organization 43(4): 673-692.

Herbst, Jeffrey. 2000. States and Power in Africa. Princeton: Princeton University Press.

Hoddie, Matthew, and Caroline Hartzell. 2003. "Civil War Settlements and the Implementation of Military Power-Sharing Arrangements." Journal of Peace Research 40(3): 303-320.

Hutchful, Eboe, e Abdoulaye Bathily. 1998. "Introduction." In The Military and Militarism in Africa, edited by Eboe Hutchful and Abdoulaye Bathily, I-XII. Dakar: CODESRIA.

Iglesias Puente, Carlos Alfonso. 2010. A Cooperação Técnica Horizontal Brasileira Como Instrumento de Política Externa: A Evolução da Cooperação Técnica com Países em Desenvolvimento - CTPD - no Período 1995-2005. Brasília: FUNAG.

IPEA. 2013. "Ipeadata." Accessed January 30, 2014. http://www.ipeadata.gov.br/

IPEA/ABC. 2010. Cooperação Brasileira para o Desenvolvimento Internacional: 2005-2009. Brasília: Instituto de Pesquisa Econômica Aplicada/Agência Brasileira de Cooperação.

IPEA/BM. 2011. Ponte sobre o Atlântico. Brasil e África Subsaariana: Parceria Sul-Sul para o Crescimento. Brasília: Instituto de Pesquisa Econômica Aplicada/Banco Mundial. Accessed February 04, 2014. 
http://www.ipea.gov.br/portal/images/stories/PDFs/livros/livros/12011 3 livropontesobreoatlanticopor2.pdf.

Jarstad, Anna. 2006. "The Logic of Power Sharing after Civil War." Paper prepared for the Workshop on Power-Sharing and Democratic Governance in Divided Society, Center for the Study of Civil War, PRIO, Oslo, Norway, 21-22 August. Accessed February 08, 2014. http://citeseerx.ist.psu.edu/viewdoc/download?doi=10.1.1.120.7869\&r ep $=$ repl\&type $=$ pdf.

Lasswell, Harold D. 1941. "The Garrison State." The American Journal of Sociology 46(4): 455-468.

Licklider, Roy. 1995. "The Consequences of Negotiated Settlements in CivilWars, 1945-1993." American Political Science Review 89(3): 681690.

Luckham, Robin. 1998. "The Military, Militarisation, and Democratisation in Africa: A Survey of Literature and Issues." In The Military and Militarism in Africa, edited by Eboe Hutchful and Abdoulaye Bathily, 1-45. Dakar: CODESRIA.

Luttwak, Edward. 1999. "Give War a Chance." Foreign Affairs 78(4): 36-44.

Mail \& Guardian. 2013a. "M23 Declares End to DRC Rebellion." November,

05. Accessed February 02, 2014. http://mg.co.za/article/2013-11-05m23-ends-its-rebellion-in-drc.

Mail \& Guardian. 2013b. "DRC M23 Rebels Surrender to UN Offensive." November $05 . \quad$ Accessed February 02, 2014. http://mg.co.za/article/2013-11-05-drc-m23-rebels-surrender-to-unoffensive/.

Maquiavel, Nicolau. 1994. Discorsi - Comentários Sobre a Primeira Década de Tito Lívio. Brasília: Editora da Universidade de Brasília.

Martins, José Miguel Quedi. 2013. "Considerações Finais: Recomposição Hegemônica e Inserção Internacional do Brasil." In Relações Internacionais Contemporâneas 2012/2: Estudos de Caso em Política Externa e de Segurança, edited by José Miguel Quedi Martins. Porto Alegre: Instituto Sul-Americano de Política e Estratégia (ISAPE).

McNeill, William H. 1984. The Pursuit of Power. Chicago: University of Chicago Press.

Montesquieu. 2002. Do Espírito das Leis. São Paulo: Martin Claret. 


\section{Igor Castellano da Silva and José Miguel Quedi Martins}

MRE. 2003. Resenha de Política Exterior do Brasil 93, $2^{\circ}$ Semestre de 2003.

Brasília: Ministério das Relações Exteriores do Brasil.

MRE. 2004a. Resenha de Política Exterior do Brasil 94, $1^{\circ}$ Semestre de 2004.

Brasília: Ministério das Relações Exteriores do Brasil.

MRE. 2004b. Resenha de Política Exterior do Brasil 95, $2^{\circ}$ Semestre de 2004.

Brasília: Ministério das Relações Exteriores do Brasil.

MRE. 2009. "Reunião do Presidente Lula com Embaixadores brasileiros na

África." Nota à imprensa n. 72, February 20. Accessed February 08,

2014. http://www.itamaraty.gov.br/sala-de-imprensa/notas-a-

imprensa/2009/02/20/reuniao-do-presidente-lula-com-embaixadores

MRE. 2010a. "Ataque a Civis na República Democrática Do Congo." Nota à imprensa n. 561, September 06. Accessed February 08, 2014.

http://www.itamaraty.gov.br/sala-de-imprensa/notas-a-

imprensa/ataque-a-civis-na-republica-democratica-do-congo.

MRE. 2010b. "Visita do Ministro Celso Amorim à República Democrática do Congo." Nota à imprensa n. 654, 10 de novembro. Acesso em 08 de fevereiro de 2014: http://www.itamaraty.gov.br/sala-deimprensa/notas-a-imprensa/visita-do-ministro-celso-amorim-a-

republica-democratica-do-congo-2013-kinshasa-11-de-novembro-de$\underline{2010}$.

MRE. 2011a. Balanço de Política Externa (2003-2010). Brasília: Ministério das Relações Exteriores do Brasil.

MRE. 2011b. Resenha de Política Exterior do Brasil 109, $2^{\circ}$ Semestre de 2011.

Brasília: Ministério das Relações Exteriores do Brasil.

MRE. 2012a. Resenha de Política Exterior do Brasil 110, $1^{\circ}$ Semestre de 2012.

Brasília: Ministério das Relações Exteriores do Brasil.

MRE. 2012b. "Pronunciamento do Ministro Antônio de Aguiar Patriota em

Debate Sobre Responsabilidade ao Proteger na ONU." Nota à imprensa n. 38, February 21. Accessed February 08, 2014. http://www.itamaraty.gov.br/sala-de-imprensa/notas-aimprensa/pronunciamento-do-ministro-das-relacoes-exterioresantonio-de-aguiar-patriota-em-debate-sobre-responsabilidade-aoproteger-na-onu-2013-nova-york-21-de-fevereiro-de-2012. 
Nisbet, Robert. 1982. Os Filósofos Sociais. Brasília: Editora da Universidade de Brasília.

Oliveira, Lucas Kerr de. 2009. "Segurança Energética no Atlântico Sul: Análise Comparada dos Conflitos e Disputas em Zonas Petrolíferas na América do Sul e África." Paper presented at the $33^{\circ}$ Encontro Anual da ANPOCS, Caxambu, Brazil, October 26-30. Accessed February 05, 2014 .

http://portal.anpocs.org/portal/index.php?option=com_docman\&task =doc_view\&gid=1785\&Itemid=229.

Oliveira, Lucas Kerr de. 2013. "Geopolítica do Atlântico Sul na Era do Pré-Sal: Desafios e Perspectivas para o Planejamento da Defesa da Soberania das Águas Jurisdicionais Brasileiras." Paper presented at the $4^{\circ}$ Encontro Nacional da Associação Brasileira de Relações Internacionais, Belo Horizonte, Brazil, July 22-26. Accessed February $05,2014$.

http://www.encontronacional2013.abri.org.br/arquivo/download?ID $\underline{\mathrm{ARQUIVO}=2658}$.

Portal Brasil. 2012. "Brasil Vai Ajudar Haiti a Formar Sua Própria Força de Segurança." July 26. Accessed February 06, 2014. http://www.brasil.gov.br/defesa-e-seguranca/2012/07/brasil-vaiajudar-haiti-a-formar-sua-propria-forca-de-seguranca.

Regan, Patrick M. 2002. "Third Party Interventions and the Duration of Intrastate Conflict." Journal of Conflict Resolution 46 (1): 55-73.

Reno, William. 1998. Warlord Politics and African States. Boulder: Lynne Rienner Publishers.

Renou, Xavier. 2002. "A New French Policy for Africa?" Journal of Contemporary African Studies 20(1): 5-27. Accessed February 08, 2014. Doi: 10.1080/02589000120104035.

Rezende, Lucas Pereira. 2013. "Uma Nova Abordagem para o Estudo do Engajamento do Brasil nas Operações de Paz da ONU." Politica Externa 21(3): 163-176.

Ribeiro, Cláudio Oliveira. 2007. "Relações Político-Comerciais Brasil-África (1985-2006)." PhD Thesis, Universidade de São Paulo (USP).

Rodrigues, José Honório. 1964. Brasil e África: Outro Horizonte. Rio de Janeiro: Civilização Brasileira. 


\section{Igor Castellano da Silva and José Miguel Quedi Martins}

Rousseff, Dilma. 2011. "Discurso da Presidenta da República, Dilma Rousseff, na Abertura do Debate Geral da $66^{\mathrm{a}}$ Assembleia Geral Das Nações Unidas." Speech at the United Nations General Assembly, New York, United States of America, September 21. Accessed February 05, 2014. http://www2.planalto.gov.br/imprensa/discursos/discurso-dapresidenta-da-republica-dilma-rousseff-na-abertura-do-debate-geralda-66a-assembleia-geral-das-nacoes-unidas-nova-iorque-eua.

SAF-SRI. 2013. Relatório Sobre a III Reunião da Cooperação Internacional Descentralizada do Brasil. Subchefia de Assuntos Federativos, Secretaria de Relações Institucionais, Presidência da República, Brasília, 23 de agosto.

SAF-SRI/ABC. 2012. Programa de Cooperação Técnica Descentralizada Sul-Sul. Brasília: Subchefia de Assuntos Federativos, Secretaria de Relações Institucionais, Presidência da República/Agência Brasileira de Cooperação, Ministério da Relações Exteriores.

Saraiva, José Flavio Sombra. 1996. O Lugar Da África: A Dimensão Atlântica Da Política Exterior Brasileira (de 1946 a Nossos Dias). Brasília: Editora da Universidade de Brasília.

Saraiva, José Flavio Sombra. 2010. "The New Africa and Brazil in the Lula Era: The Rebirth of Brazilian Atlantic Policy." Revista Brasileira de Política Internacional 53: 169-182.

Seitenfus, Ricardo. 2008. "De Suez Ao Haiti: A Participação Brasileira Nas Operações de Paz." In $O$ Brasil e a $O N U$, edited by FUNAG, 39-58. Brasília: FUNAG.

Snyder, Jack. 2000. From Voting to Violence: Democratization and Nationalist Conflict. New York: W.W. Norton.

Souza, Nali de Jesus de. 2005. Desenvolvimento Econômico. São Paulo: Atlas.

Thom, William G. 1995. “An Assessment of Prospects for Ending Domestic Military Conflict in Sub-Saharan Africa". CSIS Africa Notes 177, October.

Thomas, Caroline. 2008. "Poverty." In Security Studies: An Introduction, edited by Paul D. Williams, 244-259. New York: Routledge.

Tilly, Charles. 1985. "War Making and State Making as Organized Crime." In Bringing the State Back In, edited by Peter B. Evans, Dietrich 
Rueschemeyer, and Theda Skocpol, 169-191. Cambridge: Cambridge University Press.

Tilly, Charles. 1996. Coerção, Capital e Estados Europeus. São Paulo: Editora da Universidade de São Paulo.

Tilly, Charles. 2007. Democracy. New York: Cambridge University Press.

Toft, Monica Duffy. 2010. "Ending Civil Wars: A Case for Rebel Victory." International Security 34 (4): 7-36.

Tull, Denis M., and Andreas Mehler. 2005. "The Hidden Costs of Power-

Sharing: Reproducing Insurgent Violence in Africa." African Affairs 104(406): 375-398.

UN. 2003. Handbook on United Nations Multidimensional Peacekeeping Operations. New York: United Nations, Department of Peacekeeping Operations.

UN. 2011. "Agenda Items 14 and 117 (A/66/551-S/2011/701)." General Assembly Security Council, November 10. New York: United Nations.

UN. 2013. "Resolution 2098 (S/RES/2098)." Security Council, March 28. New York: United Nations.

Van Creveld, Martin. 2004. Ascensão e Declínio do Estado. São Paulo: Martins Fontes.

Visentini, Paulo Fagundes. 2010. A África Moderna. Porto Alegre: Leitura XXI.

Visentini, Paulo Fagundes. 2011. A África Na Política Internacional: O Sistema Interafricano e sua Inserção Mundial. Curitiba: Juruá.

Wagner, Robert H. 1993. "The Causes of Peace". In Stopping the Killing, edited by Roy Licklider. New York: New York University Press.

Weber, Max. 2000. Economia e Sociedade: Fundamentos da Sociologia Compreensiva - Vol. 1. Brasília: Editora da Universidade de Brasília.

Zacarias, Agostinho. 1999. Security and the State in Southern Africa. New York: Tauris Academic Studies. 


\title{
Igor Castellano da Silva and José Miguel Quedi Martins
}

\begin{abstract}
This article argues how Brazil can contribute for the formation of the National Army and construction of the African states by means of an embryonic particular model of international insertion, based on a specific concept of human rights and on the International Technical Cooperation. This possibility can be extended in the case of the Congo.
\end{abstract}

\section{KEYWORDS}

National Army; Brazil; Africa; Democratic Republic of Congo. 



\section{FOREIGN POLICY OF NEW SOUTH AFRICA: REINSERTION AND REGIONAL AFFIRMATION}

\section{Kamilla Raquel Rizzi ${ }^{1}$ and Nathaly Xavier Schütz ${ }^{2}$}

(...) Southern Africa (...) will only prosper if the principles of equality, mutual benefit and peaceful co-operation are the principles that govern its future. Reconstruction cannot be imposed on the region by outside forces or unilaterally by ourselves as the most powerful State in the region. It must be the collective enterprise of people in Southern Africa. (Mandela 1993)

\section{Introduction}

South Africa is a country of particular importance to understand contemporary international relations. Located in the southernmost part of the African continent, bordered by the Atlantic and Indian Oceans, South Africa occupies a strategic geopolitical and geo-economic position. With the end of the Apartheid regime in the early 1990s, the country entered a phase of international reinsertion, which has as a fundamental component the normalization of relations with other African countries, especially its neighbors in Southern Africa. The goal of this work is to analyze the foreign policy of the New South Africa (from Nelson Mandela to Jacob Zuma), with the main concern of elucidating the role that regional integration has for the South African ambitions in the world system.

1 Professor at Universidade Federal do Pampa (UNIPAMPA). Master in International Relations and PhD in Political Science by Universidade Federal do Rio Grande do Sul (UFRGS). Researcher at CEBRAFRICA. E-mail: kamillarizzi@unipampa.edu.br.

2 Professor Assistant at Universidade Federal do Pampa (UNIPAMPA). Master and PhD in Political Science by Univerisdade Federal do Rio Grande do Sul (UFRGS). E-mail: nathalyschutz@unipampa.edu.br. 
To understand the actions of South Africa post-1948, is necessary to understand the roots of the construction of the South African State. Thus, a brief history of the colonization process in the region is of value to the analysis. As occurred in other regions of Africa, the Portuguese were the first Europeans to reach the area of the Cape of Good Hope, in the fifteenth century, but facing problems with local chiefs and other strategic points in Africa under their rule, Portugal abandoned the site. Throughout the sixteenth century, the Cape of Good Hope started to be used as a replenishment point and, on the next century, the British attempted to establish trading posts in the region.

As stressed by Farley (2008), who, in fact, managed to establish successful bases in the region in 1652, was the Dutch through the Dutch East India Company. The factory established over time was expanded and became a settlement colony. During the seventeenth century, the Dutch came into conflict with the local population in some occasions: it was in this period, as well, that a class of pastors farmers was formed, the Boers. Along with the growth of the Boers, the emergence of Afrikaaner identity occurred, paternalistic and discriminatory.

In the early nineteenth century, the British managed to take control of the Cape of Good Hope, which increased the tension between the British and the Boers, strengthening the construction of the Afrikaaner nationalism. The Boers founded the State of Orange in 1854 and, ten years later, the Republic of Transvaal, which was renamed as Republic of South Africa both, according to Visentini and Ribeiro (2010), based on racist legislation. In the late nineteenth century, therefore, there were four regions of white rule in southern Africa. The Colonies of Cape and Natal, with white majority and English speakers, and the South African Republic and the Orange Free State, controlled by whites of Dutch origin.

In 1910, the English established the "Domain of South Africa", formed by the provinces of Cape and Natal (British) and Orange and Transvaal (Boer), which have adopted the principle of segregation as a base for social relations. Thus, the beginning of the construction of the racist State commenced; followed by a series of laws that made it legal and increased racial segregation in the country. Emphasis should be given to the Native Land Act of 1913, which restricted the ownership of land to blacks in $7 \%$ of South Africa's territory, 


\section{Kamilla Raquel Rizzi and Nathaly Xavier Schütz}

creating the foundation for what became the bantustans during the Apartheid period.

In 1948, the National Party, controlled by Afrikaaners and without British influence, won the elections. From then gradually the system of racial segregation known as Apartheid and the succession of laws that legitimized this oppression were implemented. As stressed by Pereira (2007, 55): "What characterized the new period was the dissociation of political and economic power; the British population kept economic power, while Afrikaaners held political power. Thus, the institutionalization of Apartheid became the pillar of the new development outbreak.

According to Swart and Plessis (2004), throughout the 1960s, South Africa sought to increase economic, political and military cooperation with other 'white' countries, as Portugal and Southern Rhodesia itself, which had not yet become independent. From a regional perspective, the policy of destabilization was adopted, targeting the newly independent countries of southern Africa contrary to the Apartheid regime.

The Apartheid regime was strongly affected by the end of the Portuguese Empire in Africa with the independence of its colonies and the Carnation Revolution in the metropolis, in the mid-1970s. South Africa was heavily involved in independence struggles in Angola and Mozambique, largely due to its need to control Namibia (Farley, 2008). With the independence of the two colonies, South Africa found itself compelled to get involved in the conflict established, especially in the case of Angola.

The new context led South Africa to revise its foreign policy, beginning a period that became known as détente. The ultimate goal of Pretoria was to create a system of constellation in southern Africa, which should ensure its political, military and economic interests in the region. In 1979, South Africa calls for the formation of a Constellation of Southern African States with antiMarxist nature, but it did not succeed.

From a domestic perspective, South Africa began to face stronger resistance from ANC, culminating with the Soweto uprising in 1976, strongly repressed by government forces. Pretoria is thus facing a double crisis: external and internal. The new situation led South Africa to adopt a new strategy of defense policy, based, according to Pereira (2007), both in the economic and 
military sphere, aimed at increasing its neighbors dependence, undermining external support to the ANC and ultimately replacing hostile governments by allies.

In the 1980s, South Africa began to also face economic problems originated in the fall of gold and raw materials prices, in a crisis context which affected the whole world system. This situation was aggravated by the military and security spending and the financial sanctions that were imposed to the country (Pereira, 2007). The Apartheid regime started to become untenable, and South Africa was forced to change its domestic and international route.

\section{The new foreign policy: from Mandela to Zuma}

Between the late-1980s and early-1990s, South Africa has undergone a process of profound transition in its social, economic and political structures. The demise of Apartheid provided conditions to end the isolation of the country in the international system.

Until the mid-1980s, South Africa sought to preserve the system as the main and almost sole aim of its foreign policy. The racist regime sought to justify its actions in defense of the interests and values of the white elite, inserted in the context of the Cold War. This segregationist, reactive and defensive regime had, however, offensive features in actions which allowed extraordinary success in the short term, notably in the neighborhood. However, at the end of the 1970s, the collapse of Portuguese colonialism also affected the balance of power in Southern Africa.

Thus, the Apartheid regime vanished between 1980 and 1994 by domestic pressures and international circumstances arising with the change in the international system. Internally, with the wave of violence and civil unrest, the depletion of the production model in which the Apartheid regime layed for decades gradually occurred, based on the generation of workforce surplus in the Bantustans to provide for the economic activities of the africaners $^{3}$ centers. $^{2}$

${ }^{3}$ At that time, the South African economy, especially in urban centers, started to required qualified workforce, not supplied by the white elite anymore, which, somehow, made part of the black workers to enter that market. Moreover, a progressive stampede of support of the business community to the government, which, by economic interests, saw in the black workforce chance of qualification. 


\section{Kamilla Raquel Rizzi and Nathaly Xavier Schütz}

Externally, the set of international sanctions, of various kinds, but especially economic, which from the end of the 1980 s began to be imposed on the Apartheid government, isolated the country. The United States of America, United Kingdom and other Commonwealth members closed their borders to trade with South Africa and recommended the end of direct foreign investments and financial transactions in the country. In fact, the Afrikaaner government began to no longer finance their spending with repression, defense and regional external interventions, having to enact debt moratorium (1985). The economic recession has worsened by the departure of transnational companies in the country and by capital flight.

The solution found was the negotiated transition. The pact between the Apartheid government (National Party) and blacks was seen as the only way to ensure the maintenance of resources to the white elite, while including blacks in the political process. This process did not occur simply due to many internal conflicts with the aim of destabilization.

President Frederik de Klerk began to dismantle the regime with the release of Nelson Mandela (1990), with the National Convention of Peace (1991) and with the 1994 elections, with the right to vote for blacks, Indians, mestizos and whites; President Mandela was elected, representing the ANC. In 1994, elections were held and the ANC won a majority of votes (62.65\%) and Mandela ascended to the presidency, but did not reach the two-thirds needed for approval of the constitution without support from other parties. The National Party won $20.4 \%$ of the voting and had the right to appoint the vice president, a position filled by De Klerk.

The interim government took office in May of the same year and began working on the new Constitution, on the organization of the committees responsible for the judgments of the abuses of the segregationist era (National Commission on Truth and Reconciliation), seeking also to reorganize the economic and social structures, inherited from centuries of exploitation of racial

However, the rules of the regime (restriction of free movement, separate access in public areas, housing and education) impaired this practice. 
bias. Negotiations also established an interim Constitution, outlining general principles that would govern the interim government and the Constituent Assembly to be formed (principles that left the property and other resources of power in the hands of the Afrikaner elite, as GINSBURG, 1996).

In clear terms, the movement that led South Africa to transition from Apartheid to a new democratic government included also the foreign policy of this period. The main feature of this process was the search for the reintegration of the country in regional politics and the normalization of international relations. To Visentini and Pereira (2010), South Africa has forged an alliance with the West, although its external action has been almost always reactive to the processes of the world system.

The South African foreign policy in the transition period has been denominated "New Diplomacy", which guidance forecast the country not as an extension of Europe, but as a middle power, recognized by its Southern peers as such. Its regional policy should be implemented through non coercive instruments. South Africa hegemony in the region, thus, is intended to be altered from geopolitical to economic. Mendonça says (2000, 42. Tradução nossa): "African problems must be solved by Africans. Common interests and responsibility in relation to economic, sociological and environmental well-being of Southern Africa should be the foundation of cooperation and good neighborliness.

Thus, it is predicted that the major change in regional policy is based on the principle of an economic expansion of South Africa to the continent. The transition was marked by distrust of both the National Party and the ANC. The foreign policy of De Klerk, on the African scene, won a diplomatic success through treaties of cooperation and the intensification of economic contacts. They sought to ensure that the normalization of South Africa's foreign affairs happen after the completion of the constitutional negotiations.

\section{The normalization of relations in Mandela's government}

Nelson Mandela formed the Government of National Unity in order to reorganize the country (with representatives from various parties who sided). The armed wings of the ANC and PAC were integrated into the defense forces of the country, which already had a quota itself. The situation of blacks linked to 


\section{Kamilla Raquel Rizzi and Nathaly Xavier Schütz}

unemployment, precarious housing, lack of access to land, education, health and conditions of social development should be resized (the Programme for Reconstruction and Development has consolidated this perspective).

However, the goals of this program did not achieve the desired success, but called attention to the possibility of direct foreign investments in the country. In 1996, year the promulgation of the new Constitution, the Program Growth, Employment and Redistribution (GEAR) was also created, with the proposed increase of economic growth in 6\% annually, creation of over 1.3 million jobs outside agriculture and $11 \%$ growth in manufacturing exports. Generally,

(...) Mandela's government consolidated democracy in the country, but the right to come and go, which blacks have benefited, took thousands of poor people to leave the reserves and settle on the outskirts of the best cities in search of better life conditions (Visentini and Pereira 2010,73).

Domestic and international issues during Mandela's term were intrinsically linked to a new South African posture. It was based on the thesis that the lasting solution to international problems would come through consolidation of democracy worldwide. Many of these principles were found in Western liberalism. Therefore, these principles followed four settings, according to Barber (2010): a) the notion of global division between the first and second world; b) the role of international organizations, central to enhancing human rights, peace and equality; c) the demilitarization and d) the position of South Africa on the African continent.

Mandela's foreign policy kept South Africa next to Europe and the U.S., as a way of increasing volumes of financial cooperation and technical assistance necessary for the conduct of internal programs to be put into action. For Mendonça, "[...] Pretoria's interpretation was that industrialized countries had a moral obligation to support the new country, for democracy they helped build could be consolidated. This aid would not have missed" (2000, 53. Our translation).

The South African government has cut ties with Taiwan and established them with the People's Republic of China (1998). Closer ties were strengthened with India, Japan, Hong Kong, the Philippines and Malaysia, major trading partners. The country sought to break the isolation with respect 
to Libya, Sudan and Cuba, which brought on tension in relations with the U.S., which had such countries as pariahs in the world system of the post-Cold War.

An essential aspect of foreign policy pursued by Mandela was related to the entry and participation in international organizations and forums. In 1994, South Africa joined the Organization for African Unity and also SADC and, since then, has sought to advance the process of economic integration in Africa. In 2001, the Third UN Conference against Racism, Racial Discrimination, Xenophobia and Related Intolerance was held. In 2002, the Earth Summit took place in Johannesburg. Another key point in Mandela's foreign policy refers to the increasing number of South African embassies: in the early-1990s, still under the racial regime, the country had only 30 diplomatic missions in the world; in 1996, that number rose to 124 diplomatic missions, being the country member of 45 international organizations.

South Africa became a prominent promoter of proactive and positive causes in the world system. As an example, cooperation with Canada and New Zealand sought to eliminate landmines. In general, Mandela's foreign policy identified the countries of the developing South as the South African priority, aligning the African continent with the new political-economic partners in the world system. Concepts such as new partnerships, possible cooperation and promotion of peace characterized the period.

\section{Mbeki's dubious policies}

In 1999, the ANC remained in power with the victory of Thabo Mbeki (two terms between 1999 and 2008). During this period, South Africa consolidated itself as the continent's higher rate of development, which economic and military power can be compared to Brazil in relation to South America. As Olivier $(2003,815)$ argues, “[...] Mbeki paints its foreign policy with a broad brush and his vision of Africa is rotund, self-establishing an agenda that is ambitious, missionary and a bit romantic, but daunting in complexity and magnitude".

During his government, South Africa obtained international recognition as a regional leader. Laurie Nathan (cited in Barber, 2010) identifies three core elements in Mbeki: democratic, Africanist and anti-imperialist. In addition, Landsberg (2012) points out that, effectively, Mbeki's government 


\section{Kamilla Raquel Rizzi and Nathaly Xavier Schütz}

sought to reconcile domestic and foreign policies, when it confirmed the "[...] African Agenda"; South-South cooperation; North-South dialogue; and socioeconomic and political securitarian issues (Landsberg 2012, 80).

Mbeki gave priority to Africa under the concept of the African Renaissance. For Mendonça (2000, 70),

The concept of an African Renaissance that has occupied the center of African politics of South Africa, operates in this adversarial context of pessimism / optimism. It recognizes the effects of colonialism, his legacy to countries with arbitrary boundaries, convulsed by ethnic divisions, with unstable political institutions and poor economies based on declining production and export of raw materials; but also recognizes those regions that are beginning to open to modernization. More than one project, however, the African Renaissance is an aspiration.

Its relations with Asia (China and Japan) and MERCOSUR (Brazil and Argentina in particular) have widened. And its projection towards the continent deepened (especially in relations with Nigeria, essential partner to Mbeki). These relations with Nigeria have intensified with the collapse of Abacha in 1999. In October 2000 Mbeki made an official visit to Nigeria and was visited by President Olusegun Obasajo. There was also an intense approximation with Zimbabwe in the period. Mbeki efforts to the continent were not only bilateral. In early 2005, Mbeki was involved in negotiating the conflicts in Côte d'Ivoire, Sudan, Burundi, DR Congo, Rwanda and Comoros, as well as Zimbabwe and Swaziland.

The Organization for African Unity (OAU) was transformed into the African Union (AU) in 2002 at a meeting in Durban, South Africa. The South African and Libyan support were decisive for the expansion of the organization's goals and creating conditions for a more intimate cooperation between the countries of the continent and true integration. Just as the NEPAD, the AU has suffered from uncertainty about its primary focus. A clear difference between the administrations of Mandela and Mbeki referred to the employment of the South African forces in peacekeeping operations of the United Nations and the African Union itself, widely accepted during the Mbeki's term, namely: UN Assistance Mission in Afghanistan, 2002; UN Assistance Mission in Iraq, 2003; UN Mission in Nepal, 2007; AU/UN Hybrid 
Operation in Darfur, 2007; UN Organization Stabilization Mission in the Democratic Republic of the Congo, 1999; UN Integrated Office in Burundi, 2007 (SIPRI 2011).

We conclude that the use of these troops promptly marked change in the type of role that Pretoria executed on the African scene, hoping to secure diplomatic prestige, claiming a permanent seat in the UN Security Council and seeking to legitimize its actions to the continent. Disregarding the dispute in Congo, Zimbabwe ended up constituting the greater external difficulty for Mbeki's government. The ambiguity of Mbeki's foreign policy refers to the hazy posture with Zimbabwe and Angola.

Internally, the Zimbabwean situation deteriorated in the 1990s when Mugabe sought to cling to power at all costs (with attacks on political opponents, election fraud, taking away freedom of expression, among other actions). As a result of the government's behavior in Zimbabwe, its economy collapsed ( $80 \%$ of the population lives below the poverty line).

Barber (2010) argues that Mbeki rejected the British 'megaphone diplomacy' for Zimbabwe and Africa in general. According to Mbeki, the population of that country should decide and solve its own problems and its current difficulties are legacies of colonialism and white rule. Therefore, for the President, South Africa should play a "quiet diplomacy" to encourage dialogue between the Zimbabwean government and its political opponents (Mugabe and Mbeki accused Tony Blair and John Howard of being racist, at various times). Mbeki defended Mugabe and his government, although there was no personal affinity between the two (for Barber, many Africans see Mugabe as a hero for being from the first generation of African leaders, the only one who is still in power).

The differences between Mbeki and his vice-president, Jacob Zuma, were acute between 2001 and 2005. After corruption charges for involvement in an arms deal, Zuma was dismissed in 2005 (Zuma had the support of left-wing allies of the ANC). From this point on the opposition to Mbeki's leadership started growing. In September 2008, Mbeki resigned (eleven ministers followed, including the finance minister, Trevor Manuel). With Mbeki's departure, the government was provisionally assumed by Kgalema Mothlane. Trevor Manuel showed himself willing to return to the post of Minister, stabilizing the country's finances. 


\section{Zuma's term}

Jacob Zuma, also a member of the ANC, was elected president in 2009. Already in 2009, in the "Medium-Term Strategic Plan to guide the Governmental Programme for the Electoral Mandate of 2009-2014", the foundations of Zuma's foreign policy fitted the denomination of "Quest for the Africa Progress and Strengthening of cooperation." This notion becomes clear in the following pillars of external action taken by Pretoria:

1) Fill the gap between domestic and foreign policy, or the so-called 'national interests'; 2) Promote the integration of the Southern Africa Development Community; 3) Prioritize the African continent through the 'African advancement'; 4) Strengthen South-South relations; Improve strategic relations with the North; 5) strengthen political and economic relations; and 6) Participate in the global governance system (Landsberg 2012, 80).

The Department of International Relations of South Africa, in 2009, changed its name to the Department of International Relations and Cooperation (DICO), giving more emphasis to the goals of cooperation and development ${ }^{4}$. South Africa, from 2009 to the present, solidified its essential role as a representative of the African continent in most international organizations and international dialogue forums. Its regional leadership has been recognized and respected by most African countries and partners in the world system. Although Zuma has emphasized not following Mbeki's "quite diplomacy" on regional issues, it is observed that his government continued the nonconfrontational approach, based on the notions of "promoting peace, security and stability." Zuma reapproached Angola, when he made his first official visit to this country, in August 2009, identifying that Luanda ${ }^{5}$ would become the largest African partner of South Africa in his government, over Nigeria, Mozambique and Zimbabwe.

\footnotetext{
${ }^{4}$.It is worth mentioning that Zuma headed the intelligence service of the ANC during the struggle against apartheid, being in exile in Angola and Mozambique, with whose leaders maintained good relations, unlike Mbeki.

${ }^{5}$ Zuma and his entourage of about 150 South African businessmen visited Luanda, identified as South African "strategic partnership", believing in the potential of bilateral relations between the two countries in all spheres, economic, social and political. As a result of this visit, six agreements on trade and in the area of aviation were signed.
} 
South African post-apartheid has endeavored to implement a nonhegemonic posture and non-confrontational toward its continental neighbors. The two main pillars of South Africa's cooperation with the countries of southern Africa in the contemporary world are the SACU and SADC, as will be seen below. In both South Africa has played an important role, besides hosting the secretariat of NEPAD since its inception.

From 2001 onwards, the "Butterfly Strategy" came to compose the relations of South Africa, in two equally important notions: west and east, in what referred actions and partnerships with the South. Commercial and political connections with Asia increased in importance, especially with China, and a closer relationship with Latin America began to occur, especially with Brazil.

\section{Resizing regional relations}

The reintegration of South Africa after the end of Apartheid Regime has its basis on regional relations. Over more than forty years during which the National Party ruled, relations with neighbors were strongly affected by the deliberate policy of destabilization and by the aggressive posture of South Africa. The main regional organization has its origin in an attempt to contain South Africa. In the Front Line States (FLS) ${ }^{6}$ lies the motivation for the creation of the Southern Africa Development Community (SADC).

SADC was established in 1980 with the name of Coordinated Conference for Development in Southern Africa, with the Lusaka Declaration, involving nine countries ${ }^{7}$. After the independence of Mozambique, Angola and Zimbabwe, according to Murapa (2002), the leaders of the Front Line States felt the need to address also economic issues. After a meeting in Tanzania, it was decided to develop the possibility of establishing a regional mechanism for economic

${ }^{6}$ The Front Line States were created in 1975 by the Heads of State of Botswana, Tanzania, Zambia and Mozambique. The FLS were born as a cooperation forum among States, without being a formal institution with the objective of coordinating policies in support of national liberation movements and reduce dependence of countries in the region in relation to South Africa.

${ }^{7}$ Angola, Botswana, Lesotho, Malawi, Mozambique, Swaziland, Tanzania, Zambia and Zimbabwe. 


\section{Kamilla Raquel Rizzi and Nathaly Xavier Schütz}

development issues in the countries of Southern Africa. In this meeting lies the origin of SADCC.

In 1992, with the Treaty of Windhoek, SADC takes the place of SADCC and, two years later, with the end of apartheid and the new political context in South Africa, this country joins the Organization. The entry of South Africa into $\mathrm{SADC}$ is a mark in its regional reinsertion, and in the resizing of the objectives of the Community.

The decision of the South African government to become quickly part of the main integration process of the region and an important discussion forum shows Mandela's concern to make clear to the neighbors the new posture of South Africa post-apartheid. It must be recalled that, with the end of the segregation system, the conflicting views of the National Party and the ANC came into dispute: while the National Party called for an international presence focused on trade liberalization and attracting multinationals, the $\mathrm{ANC}$ aimed at developing through regional integration. Participation in SADC was, thus, the assertion of the second strategy.

Some years after the entry of South Africa, SADC undergoes a major change: the creation of the Organ on for Politics, Defense and Security (OPDS) in 1996. The creation of the OPDS, in a way, brings into SADC the Front Line States, which, according to Malan (1998), had ended their independent activities in 1994 and decided to act as the political-securitary arm of SADC. The Organ is created, however, almost as an independent structure, in the format of a Summit, which did not refer to the SADC Summit.

The double structure SADC-OPDS eventually translated into a dispute over the leadership of the region. The presidency of the SADC Summit was held by Mandela, while the presidency of the OPDS Summit was occupied by Mugabe, from Zimbabwe. Until the entry of South Africa into the SADC, Mugabe, as Schoeman (2007) points out, even informally, was the leader of the regional organization, since it was a major economic and military force, besides being an important figure in the anticolonial struggle. The figure of Mandela and the economic and political importance of South Africa, however, puts Mugabe in the background.

This confrontation by the main role in SADC and in the Southern African region is quite evident during the crisis in the Democratic Republic of 
Congo in 1998. On occasion, as Francis (2006) points out, Zimbabwe was the first country to express support for the Congo, claiming that Rwanda and Uganda had invaded its territory and that SADC countries should intervene. South Africa, meanwhile, was opposed to military action. Finally, Angola, Zimbabwe and Namibia sent troops to Congo in an operation that was recognized as SADCs retrospectively. The action in the Congo makes clear both the opposing positions of Mandela and Mugabe as the problem of maintaining a regional organization with, in practice, two upper bodies.

South African foreign policy in the early years after the end of apartheid, thus, aimed at reintegration of the country in the region and image reconstruction of the country to the neighbors. The country's actions were, therefore, quite centered in the figure of Mandela, who had very positive relations with other countries in the region because of the support to ANC during the struggle against the Afrikaaner government and also, as Pereira (2007) reminds, the number of visits and conversations made by Mandela during the transition period in order to ensure support for his new plans for South Africa

The great exception to this attitude of rapprochement and cooperation of South Africa in relation to its neighbors was the intervention during the crisis in Lesotho in 1998. After the elections and with the imminence of a coup, the Government of Lesotho requested assistance from SADC to ensure its maintenance. What follows, as Maroleng (2007) reminds us, is a meeting between the Defense Ministers of SADC, of which Zimbabwe refused to participate, in what is decided that South Africa and Botswana should lead an operation in Lesotho under the auspices of SADC.

The operation, despite successful from the point of view of results, achieving stabilization in the country, which is consolidated with the holding of elections in 2002, is deeply criticized. The main question fell precisely on the participation of South Africa. As Neethling highlights (1998, 2), the operation "[...] was a dramatic event and a milestone for the new South Africa - the first time the post-Apartheid government employs troops in foreign territory in conflict". The accusation that South Africa had conducted a military 


\section{Kamilla Raquel Rizzi and Nathaly Xavier Schütz}

intervention in Lesotho to defend national interests ${ }^{8}$ was reinforced by the negative response, some months before, from the same South Africa to participate in the operation in the Democratic Republic of Congo.

The participation, or refusal to participate, in operations in the region and its own attitude toward crisis in neighboring countries also show, once again, the dispute, though not declared, of leadership in the region, led by Zimbabwe in particular. While South Africa followed its more friendly posture, which meant the lowest possible involvement in the domestic affairs of other countries - which explains both the denial to participate in the operation in the Congo as the decision to intervene in Lesotho - Zimbabwe also tried to assert its position of power pole, using its position in the OPDS.

It is only since the late 1990 s and early 2000 s, already during the Mbeki government, when South Africa began to adopt a more active foreign policy, symbolized by the African Renaissance. From a regional perspective, the clearest manifestation of this new phase is the major role in the formulation and conduct of the New Strategic Plan for Africa's Development, NEPAD. The early 2000 s also coincided with reforms in SADC which, at least from an institutional point of view, solved the problem of OPDS, including it within the framework of the Community.

Moreover, this is the period in which the Zimbabwean crisis developed, when South Africa's leading role of mediator in the Southern African region was put to the test. The violent actions of Mugabe's supporters, which preceded the 2002 elections, and clashes with the main opposition force, the Movement for Democratic Change, put the country in a violent crisis.

The position of SADC as an organization initially was of solidarity to Zimbabwe, with some minor changes since 2001, with the removal Mugabe from the presidency of OPDS (Cawthra 2010). The moment, however, was actually of change in the structure of SADC, as already mentioned, which puts in doubt whether the action, in fact, represented some kind of condemnation to Mugabe's actions. South Africa, meanwhile, adopts a dubious posture, what

${ }^{8}$ South Africa had significant investments in Lesotho, especially in the energy sector. 
became known as 'silent diplomacy', and consisted in publicly show support to Zimbabwe, but confidentially, advise Mugabe to make reforms.

The adoption of this posture by the Pretoria government, according to Alden (2010), had two main reasons. The first issue was economic, considering that Zimbabwe was the main trading partner of South Africa on the continent and that economic sanctions could have a big impact on South African companies. The other reason was related to the regional context and the great instability that could be generated with the departure of Mugabe from power, with the possible influx of refugees.

The crisis in Zimbabwe reveals two aspects of South Africa's relations with the countries of Southern Africa. The first is the weakening of Zimbabwe, both domestically and externally, making it impossible to continue to contest the position of leadership of the region. The second issue to be considered is the South Africa's inability at that time to assume its leading stance in the region, given that it had not yet fully disentangled from the image of apartheid, and also why it could not take a firmer posture.

The actual reintegration of South Africa in the regional scenario materialized in the late 2000s, with Zuma's government. As pointed by Visentini and Pereira (2010), unlike Mbeki, who spent much of the period of apartheid in Europe, Zuma went into exile in neighboring countries, which ensures a very positive history of relations with Angola and Mozambique. Thus, there is a booster for regional integration and intensification of relations with neighbors. The emphasis on multilateralism, as it is a major axis of South African foreign policy, is also an easier form of reinsertion, given that it helps to diminish the mistrust of other countries.

\section{Final Thoughts}

The foreign policy of the New South Africa has consolidated with Mandela, Mbeki and Zuma governments, to a greater or lesser degree, from the discourse and actions largely based on the notion of concretion of cooperation and construction/consolidation of new partnerships. These new directions, to East or West, but keeping attention to the North, qualified the reinsertion of the country in the post-Cold War world system. 
The multipolarity of this system has enabled new actors with regional relevance to be able to consolidate its action on the system, in order to facilitate the formation of coalitions among equals, such as IBSA, BRICS and the WTO negotiations.

In this sense, the African continent has consolidated, naturally, as the essential and priority agenda of South African foreign policy. The continental demands, crisis, conflicts and regional integration processes have become a frequent theme during Mandela, Mbeki and Zuma governments, but with punctual and specific actions in each. While Mandela argued that all African countries had the same importance for the South Africans, in a sense of cooperation for peace building and democracy in the world, Mbeki - in a clear notion of what type of regional balance of power was sought - prioritized relations with Nigeria and Zimbabwe, as a way of legitimizing regional actions, given the context of the relevance of Mugabe's government until the late 1990s. Zuma, in turn, rapproached Angola, as a counterpoint to the Zimbabwe decay in the region, and taking into account Luanda's recovery and emergency as important pole of power in Southern Africa.

It is noticed, therefore, that the foreign policy of the new South Africa, prioritizing regional relationships and acting promptly in continental diplomacy, also reinvigorated the integration processes as vectors of the South African rapprochement to its neighbors. Thus, the medium and long-term perspectives are to consolidate these processes based, on the one hand, in the Angolan assertion and, on the other, in the South African maintenance as two alternative poles of regional power. 


\section{REFERENCES}

Alden, Chris. 2010. "A Pariah in our Midst': Regional Organizations and the problematic of Western-designated pariah regimes - The cases of SADC/Zimbabwe and ASEAN/Myanmar." Crisis States Research Centre/LSE Working Paper 73, May.

Barber, James. 2005. "The New South Africa's foreign policy: principles and practice." International Affairs 81(5): 79-96.

Beck, Roger B. 2000. The History of South Africa. Westport: Greenwood Press. Bond, Patrick. 2000. Elite transition: from Apartheid to neoliberalism in South Africa. London: Pluto Press.

Carlsnaes, Walter. 2008. "Actors, structures and foreign policy analysis." In Foreign Policy: Theories, Actors, Cases, edited by Steve Smith, Amelia Hadfield and Timothy Dunne, 85-100. Oxford/New York: Oxford University Press.

Cawthra, Gavin. 2010. "The Role of SADC in Managing political crises and conflict - The Cases of Madagascar and Zimbabwe." Friedrich Ebert Stiftung (FES) Peace and Security Series 2.

Dopcke, Wolfgang. 1998. "Uma nova política exterior depois do Apartheid? Reflexões sobre as relações regionais da África do Sul, 19741998." Revista Brasileira de Política Internacional 41(1). Accessed July 25, 2010: http://www.scielo.br/pdf/rbpi/v41nl/v41nla07.pdf.

Francis, David J. 2006. "Linking Peace, Security and Developmental Regionalism: Regional Economic and Security Integration in Africa." Journal of Peacebuilding and Development 2(3).

Mendonça, Hélio Magalhães de. 2000. "South African Foreign Policy, 19451999." In Brazilian Views on South African Foreign Policy, editado por Samuel Pinheiro Guimarães, 11-90. Brasília: FUNAG.

Landsberg, Carl. 2012. "A política externa do Governo Jacob Zuma: associação ou dissociação?" Austral: Revista Brasileira de Estratégia e Relações Internacionais 1(1), 79-108.

Malan, Mark. 1998. "Regional Power Politics Under Cover of SADC - Running amok with a Mythical Organ." ISS Occasional Paper 35, October.

Mandela, Nelson. 1993. "South Africa's Future Foreign Policy." Foreign Affairs 72(5). Accessed $\quad$ February 10, 2014: http://www.anc.org.za/show.php?id=4113 


\section{Kamilla Raquel Rizzi and Nathaly Xavier Schütz}

Maroleng, Chris. 2007. "Lesotho: On the path to democracy and stability?" ISS Situation Report, March 06.

Murapa, Rukudzo. 2002. "A Comunidade de Desenvolvimento da África Austral (SADC): rumo à integração política e econômica." Impulso 31, September.

Neethling, Theo. 2002. "Military Intervention in Lesotho: Perspectives on Operation Boleas and Beyond." The Online Journal of Peace and Conflict Resolution 2(2), May.

Olivier, Gerrit. 2003 "Is Thabo Mbeki Africa's Saviour?" International Affairs 79(4): 815-828.

Pereira, Analúcia Danilevicz. 2007. “África do Sul e Brasil: dois caminhos para a transição ao pós-Guerra Fria (1984-1994)." Tese de Doutorado apresentada ao Programa de Pós-Graduação em História da Universidade Federal do Rio Grande do Sul, Porto Alegre.

Schoeman, Maxi. 2001. "From SADCC to SADC and Beyond: The Politics of Economic Integration." Alternative Regionalisms, 13 de julho. Accessed February 22, 2013:

http:/www.alternative-regionalisms.org/wpcontent/uploads/2009/07/schoemar fromsadcctosadc.pdf.

Swart, Gerrie, and Anton du Plessis. 2004. "From Apartheid to Destabilisation to a Southern African Security Community." In Towards a Common Defence and Security Policy in the Southern African Development Community, edited by Hussein Solomon. Pretoria: AISA.

Visentini, Paulo G. Fagundes, and Analúcia Danilevicz Pereira. 2010. "A Nova África do Sul: política, diplomacia e sociedade (1994-2010)." In África do Sul: História, Estado e Sociedade, organized by Paulo Gilberto Fagundes Visentini and Analúcia Danilevicz Pereira, 65-96. Brasília: FUNAG. 


\begin{abstract}
South Africa is a country of singular importance for the understanding of contemporary International Relations. Situated at the Southernmost region of the African continent, coasted by the Indian and Atlantic oceans, South Africa occupies a geopolitical and geoeconomic strategic position. In the beginning of the 1990s, with the end of the Apartheid regime, the country starts a period of international reinsertion that presents as a fundamental feature the stabilization of the relations with the other African countries, especially its neighbors of Southern Africa. The objective of this article is to analyze the foreign policy of the New South Africa (from Nelson Mandela to Jacob Zuma), presenting as a central thread the role played by regional insertion for the South African ambitions in the international system.
\end{abstract}

\title{
KEYWORDS
}

South Africa; Regional Integration; Foreign Policy. 


\section{COOPERATION AND CONFLICT: THE DYNAMICS OF OIL AND GAS IN CENTRAL \\ ASIA}

\section{Paulo Duarte ${ }^{1}$}

\section{Introduction}

The current article analyzes some paradigmatic cases of the tension between conflict and cooperation, of the limited cooperation and of the difficulties for initializing cooperation processes in Central Asia, notably in relation to oil and natural gas. The central argument is that hydrocarbons are frequently generators of rivalries that prevent significant advances in the Central Asian regional integration.

International security practices have underlying games of cooperation and conflict, or, in other words, competitive and cooperative games. Welch and Wilkinson (1999) state that conflict and cooperation coexist in interdependence situations and, hence, it is important to understand why conflicts develop. According to Tjosvold and Johnson, "being alive is to be in conflict" $(1989,1)$. Conflicts are "natural situations in any kind of relationship" (Tjosvold and Johnson 1989, 1). Defined in broadly terms, conflict denotes "the incompatibility of ideas" (Diez et al 2006, 565). This definition leaves open the exactly nature of such incompatibilities, that is, "to what extent they occur between individuals, groups or social positions"; to what extent they reside in

${ }^{1}$ Researcher at the Instituto do Oriente, Lisbon, Portugal. International Relations PhD candidate at the Instituto Superior de Ciências Sociais e Políticas of the Universidade Técnica de Lisboa - ISCSP-UTL, Portugal. E-mail: duartebrardo@gmail.com. 
"different interests and beliefs"; and how far they have "a material existence" or "gain existence only through discourse" (Pia and Diez 2007, 2). Deutsch (1973) presents some variables that affect the course of a conflict, including the characteristics of the parties involved in it and the history of their relationship and the nature of the question that originated the conflict. Another feature of conflict lies in the fact that it generates changes. System's stability is placed under turbulence, continuing to exist until a new equilibrium is reached (Stern and Gorman, 1969).

States and individuals do not have, necessarily, to pursue a logic of conflict, to the extent that they can opt for cooperation. By cooperation, it is meant any form of social interaction between actors that allow them to reach, voluntarily, a set of common goals through the sharing of certain resources (Hebert 1996). However, even though cooperation is "a concept endowed with a positive charge", it does not, necessarily, presuppose "a harmonious relationship, devoid of conflicts" (Siitonen 1990, 7). Rather, cooperation may involve hidden power struggles between partners and/or a domination mode of one actor over another. This is related to the "cooperation social context", and, therefore, with "our ideas of social systems as contexts of cooperation and conflict" (Siitonen 1990, 7). What, then, characterizes international cooperation? According to Jean Touscoz, "international cooperation refers to all 'projects' that allow international actors to achieve defined goals together, through the sharing of resources" $(1981,17)$. Less than integration, however, more than common sporadic efforts, "international cooperation aims to the establishment of relations between sovereign actors willing to share some values" (Siitonen 1990, 7).

Security cooperation is, in general, perceived as "the collaboration among parties in conflict"; this is the reason why alliances are often treated as sui generis entities" (Muller, 2002: 370). This distinction, nonetheless, is not entirely convincing. If international relations are marked by anarchy, in which conflict is possible, then "alliances tend to be problematic" (Muller, 2002: 370). On the other hand, if temporary cooperation, performed to rule out any imminent threat, encourages too much one of the partners, "cooperation may translate into less security instead of more, and in a loose of sovereignty in the worst cases" (Muller 2002, 370). 


\section{Paulo Duarte}

\section{Important oil and gas pipelines at the regional level}

In oil diplomacy, it is essential to take into consideration a matter which is, in Rachel Freire's understanding (2012), "often relegated to the sidelines", that is related to the "rentier" states, i.e. states that receive "income through the passage of oil and gas pipelines" (Mahdavy 1970; Kaldor et al 2007). It is the case of Turkey, for example, which has already been asserted, according to Rachel Freire (2012), as a "power core". Another important issue to consider in oil diplomacy, as underlined by Rachel Freire (2012), is that of "dependencies". In this regard, the specialist highlights the example of Russia, sort of a "giant that controls and features", although, in practice, the country also needs stable buyers (Freire 2012). In turn, as stated by António Costa Silva (2012), "all Eastern Europe states show a strong dependence on Russian natural gas", what has caused "many quarrels between Moscow and these countries in terms of energy tariffs", in contrast with the stability climate in energy supply by Moscow to the European markets in the Soviet era.

The geographic isolation of Central Asian republics raised the question on how to put their energy resources on the market (Chow and Hendrix 2010). In response to this situation, men tried to circumvent the adversities imposed by nature building gigantic structures, large pipelines that allow the draining of oil and natural gas production, attenuating, on the other side, the big CentralAsian republics' dependence in face of the logistical infrastructure of neighboring Russia (Fonseca, 2011). It is interesting to note that while agreements, alliances and treaties can be ignored, dismissed or subjected to change, pipelines survive the circumstances that gave rise to them, as "umbilical cords of steel", which unite economic and, often, political interests (Blinick, 2008). A significant part of the "New Great Game" in Central Asia assumes the construction of oil and gas pipelines (Fishelson 2007). These constitute vital arteries, susceptible to connect the region to the global economy (The Encyclopedia of Earth 2007). Once built, pipelines cannot be removed or redirected. Moreover, they symbolize strategic commitments when ensuring the

${ }^{2}$ The expert is President of the Executive Committee of the Partex Oil \& Gas Group. 
continuous flow of energy throughout the project's life expectancy (Demir 2012; Seaman 2010).

Once overcame an initial hurdle, i.e. "the decision to build infrastructure capable of mitigating Central Asian republics' isolationism", it is necessary to resolve another question: "what routes should the pipelines take?" (Fonseca 2011). Certainly, the West would be a good option due to the broad market it is capable to offer to the Central Asian resources. Nonetheless, "let oil and gas flow only to the West could compromise the diversification of consumer's policy" (Fonseca 2011). In other words, it was also important to ensure that energy resources would reach the East, building up, to such end, infrastructure capable of transporting oil and gas to neighboring China. Betting on the Middle Kingdom and, to some extent, in India, provides the CentralAsian republics "greater capacity of negotiation", preventing, at the same time, the occurrence of any monopoly: "West and East are presented as two separate markets, but needed to the producers of oil and gas" (Fonseca 2011). On the other hand, according to Emílio Rui Vilar" (2011), "it is in the interest of Europe to create alternative routes to the pipelines crossing Russia (under which Turkey and Caucasus' countries have played an important role)", a strategy that aims to "diversify supplies to the European continent, which has not followed a coordinated policy in this regard".

Since the collapse of the Soviet Union, multiple pipelines have been negotiated and constructed in order to transport oil and gas from the Caspian Sea into all directions: "West - to Black and Mediterranean Seas; East - to China; North - to Russia; and South - to Iran and, possibly, to Afghanistan" (Bahgat 2006, 10). The decision to build a pipeline system is not only based on the cost analysis of a project, however. As Jean-Paul Rodrigue and Brian Slack state, "geopolitical interests play a key role in the selection of the transit countries for the pipelines" (2013, para. 1). Moreover, as the experts add, "the pipelines routes that link the Middle East to the Mediterranean were designed to avoid their crossing through Israeli territory" (Rodrigue and Slack 2013, para. 3). Furthermore, "the planning of new pipelines that are designed to link

${ }^{3}$ Ex-President of the Calouste Gulbenkian Foundation. 


\section{Paulo Duarte}

Central Asia to the Mediterranean seeks to take into account the ethnic and religious mosaic of the Caucasian Republics" (Rodrigue and Slack 2013, para. 3). Pipelines' construction costs vary with their diameter, increasing proportionally to the distance (and consequently necessity of pumping stations) and the viscosity of the transported fluids (Rodrigue and Slack 2013, para. 4). An argument that weighs in the decision to build these infrastructure is, according to Gawdat Bahgat, the wish that countries bordering the Caspian Sea have in "achieving political and economic independence from the Russian giant", as well as "to deprive Tehran of any political or financial benefit" (2006, $10)$.

There are four major routes that a pipeline could follow through Central Asia (U.S. Congressional Record 1998; Ventura 2010). The first and most common, through North, crossing Russian territory, towards ports located in the Black Sea, or into the Russian pipeline system (Badalyan 2012). The second is the Western route, through Turkey, either by the Caucasus Mountains, or via Caspian Sea (U.S. Energy Information Administration 2013). Both routes raise security problems, and the cost of building a pipeline along these tracks is considerable high. The shorter route is through South, going through Iran, a path that is politically unacceptable to the United States and that displeases most Western energy investors (Kaplan 2012; Greenwald 1996; Rodrigue and Slack 2013). In this regard, Edward Chow and Leigh Hendrix consider that "apart from the existence of international sanctions and other political barriers, a southern route via Iran remains a credible alternative to Kashagan", located alongside Kazakhstan's coast, which may eventually produce "more than a million barrels of oil per day" $(2010,35)$. Nevertheless, the emergence of such route is dependent on the international situation's political evolution, at the time that Kashagan start producing large quantities of oil, at the end of the decade (Chow and Hendrix 2010, 35). The creation of a southern route has as advantage the cost reduction by connecting it to Iran's existing pipeline system, and by adding another direction, aiming to diversify the routes for Caspian oil" (Chow and Hendrix 2010, 35). However, despite Iran constitutes, in theory, a perfect viable option regarding the export of oil from the Caspian Sea to Asian markets, in practice, tense relations between the international community and Tehran reduce substantially the interest for this possibility. 
Meanwhile, the Eastern route is not only very costly, but could also lead, on the other hand, to China coming to absorb most, if not all, the exports (U.S. Congressional Record 1998). The last option is, as Morgan Davis emphasizes, "probably, the most desired by the United States, the path to the southeast, through Afghanistan, Pakistan and India" (2011, 445). However, due to violence and instability in Afghanistan, this route involves high risks in terms of security (Dawncom Business 2012).

Compared to gas pipelines, oil ducts are the most common logistics infrastructure in Central Asia (Worldwide Pipeline Construction Report 2012). Currently, there are several important oil pipelines in the region.

Starting with the Baku-Tbilisi-Ceyhan oil pipeline (BTC), this carries "more than a million barrels of oil per day from the coast of Azerbaijan, at the Caspian Sea, to the Mediterranean coast of Turkey", with a length of "1,768km" (Iftekharul Islam 2012, 38). Among BTC's shareholders stands out British Petroleum (BP), the major shareholder, Unocal, and ConocoPhillips (The Guardian 2012). The oil pipeline Baku-Tbilisi-Ceyhan is, probably, the most controversial of the existing ones in the region (International Finance Corporation: Lessons of Experience 2006). Among the reasons that led to its construction, it is underlined the necessity to diversify Europe's energy supply (extremely dependent on oil from the Middle East), as well as to reduce the dependence of Central-Asian oil producers in face of Moscow's controlled oil pipelines (Iftekharul Islam 2012). To Starr and Cornell, "in the post-imperial era, when many Russian politicians still believed to be possible to restore Moscow's dominance in the Caspian basin, the construction of BTC could jeopardize the "recent independences", since "it would divert the energies invested in creating independent free states and societies to negligible geopolitical concerns" $(2005,8)$. Despite these fears, BTC was so much awaited that, at its opening ceremony in 2005, the then U.S. President George W. Bush had referred to the project completion as "a monumental feat, which opens a new era in exploitation at the Caspian basin" (Sultanova 2005, 8). It is noteworthy that this would never have been realized without the steadfast political support of the United States, as it has been recognized by the President of Azerbaijan, Ilham Aliyev, in 2005 (Yevgrashina 2005).

Another oil pipeline, the Baku-Novorossiysk, with a transport capacity of 100,000 barrels per day, connects Azerbaijan's coast, in the Caspian Sea, to 


\section{Paulo Duarte}

the Russian port of Novorossiysk, in the Black Sea (Iftekharul Islam 2012). The oil pipeline Baku-Supsa, by its turn, stretching from Azerbaijan to the Georgian port of Supsa, in the Black Sea, "has a limited transport capacity $(115,000$ barrels per day)" (DeLay 1999, 73). Its opening was a "remarkable achievement for Azerbaijan, for Georgia, as well as for international energy companies" (DeLay 1999, 73).

For its part, the Atyrau-Samara oil pipeline "is owned by Russia and carries oil from Atyrau, in Kazakhstan, to Samara, in Russia", with a transport capacity of "300,000 barrels per day" (Davis 2011, 445-446).

Regarding the Kazakhstan-China pipeline, it is noted that Beijing has proposed, for the first time, the construction of an oil pipeline to Kazakhstan in 1996. Western experts considered it unworkable in the long term due to its considerable length, as well as the underlying engineering challenges to its construction, and the difficult political situation in the region (Energy Information Administration 2008). Both Moscow and Washington opposed the project. Russia encouraged the Kazakh government to exclusively use Russian pipelines, and the United States argued that the oil surplus from Tengiz should be sent by sea (across the Caspian Sea) to Europe (Kleveman 2003). However, the Chinese continued with the construction in September 2004 and, "at December 15, 2005, President Nursultan Nazarbayev authorized the commencement of filling about $1,000 \mathrm{~km}$ of the pipeline" (Oil, Gas \& Energy Law Intelligence 2006, 3). The oil pipeline connects Atasu, in central Kazakhstan, to Alashankou, in Xinjiang. In 2006, it had transported about 200,000 barrels per day to the Chinese Dushanzi refinery (PetroChina 2006). The then Chinese Vice-President of PetroKazakhstan, Zhou Jiping, even claimed that this was the "new Silk Road" (Pala 2006, para. 7). Nonetheless, even though Kazakhstan's oil production has doubled since the late $90 \mathrm{~s}$, when the Kazakhstan-China oil pipeline has been negotiated, it has operated well below its maximum capacity. Indeed, as Oleg Egorov (2011) explains, the pipeline has transported "approximately 10 million tons of oil", having been "projected to carry out double of that capacity".

Another important infrastructure is the Caspian Pipeline Consortium (CPC), which carries about 730,000 barrels of oil per day from Tengiz (Kazakhstan) to the Russian port of Novorossiysk (Black Sea), being owned 
and operated by a consortium of Western oil companies, as well as by Russian, Kazakhs and Omani state-owned companies (Chevron 2011; Iftekharul Islam 2012). Completed in 2001, the Caspian Pipeline Consortium was, from the beginning, as Adrian Dellecker notes, "the result of a delicate balance between states, eager to maintain control over the oil flows, and private companies, capable of financing the much needed infrastructure" $(2008,2)$.

The future of oil pipelines in Central Asia will depend, in large part, on the fate of the oil produced in Kashagan. This field is the world's largest discovery in the last thirty years, and the only significant oil discovery in the Caspian since it was open to foreign exploitation, owning approximately 30 billion barrels of oil, of which an estimated 8 to 12 billion are potentially recoverable (Upstream - The International Oil and Gas Newspaper 2013). When Kashagan reach its peak production of more than one million barrels per day, Caspian's volume of oil will tend to, probably, double to around 1.5 to 3 million barrels per day, heading, this way, in direction to meet the expectations of the $90 \mathrm{~s}$, which indicated that the Caspian would become a kind of renowned oil province, alongside the North Sea at its peak (Mukhtarov 2012; U.S. Energy Information Administration 2012).

Since Kashagan's oil field discovery in 2000, however, its energy potential's exploitation has suffered several delays "due to a fiscal issue between the Kazakh government and the investors in the field", as well as due to the scale and technical complexity of the project (Embassy of the Kingdom of the Netherlands in Kazakhstan, 2012: 2). Among the many uncertainties still to be clarified in regard to Kashagan, it continues for being explained how its oil will be exported. It should be noted that, in this regard, "about $80 \%$ of Kazakh oil arrives at international markets through Russia" (The Business Year 2011, para. 4). The Atyrau-Novorossiysk, Atyrau-Samara and Atyrau-Alashankou oil pipelines constitute the main export routes for Kazakh oil. In order to bypass Russia and to find new ways to export oil to the West, there have been planning for other routes.

There are, however, other questions to be answered, according to Chow and Hendrix $(2010,39)$ :

(...) in view of its vast energy potential, will Kashagan originate a new export system, such as Tengiz did with the Caspian Pipeline Consortium, or as the Azeri- 


\section{Paulo Duarte}

Chirag-Guneshli did with the Baku-Tbilisi-Ceyhan oil pipeline?; Will Kashagan provide the creation of a new route to the South, through Iran, or will it benefit, instead, the already existing corridors through Russia, China, or through the Caspian and the Caucasus?; Alternatively, will the oil tend to flow in two or three different directions with a view to diversify export routes?; Who will take the biggest strategic and commercial decisions: the Kazakh government, the national oil company, KazMunaiGaz, or the major international oil companies (ENI, ExxonMobil, Shell, Total, ConocoPhillips, Inpex)?

The answer (still uncertain) for these questions will have a fundamental impact on Central Asian oil exploration. The gas pipelines network in Central Asia is owned and controlled almost entirely by the Russian Gazprom (The Encyclopedia of Earth 2008). As Azarch Luba explains, "[energy] trade with the Central Asian Republics brings advantages to Moscow, which can benefit from the usage of former Soviet energy infrastructure" (2009, 61-62). As an example, the cost for maintaining this is inferior to the "required investment for the construction of new pipelines" that "China and Europe have to do" (Azarch $2009,62)$. The vast reserves of natural gas in the region have generated many competing proposals in relation to the construction of pipelines. Among the many factors that are likely to influence in their future are, "the economic viability of the planned transit routes, the Russian desire to limit competition for their share of the European gas market, and the growing Chinese interest in ensuring the supply of natural gas from the Caspian and Central Asia" (Weiss et al 2012,13$)$.

Among the main existing gas pipelines in the region, let us begin by highlighting the Central Asia Center Pipeline, built in 1974, which has two branches (Davis 2011). The West branch transports natural gas from the Caspian Sea's Turkmen coast to North, where it intersects with the East branch, in Western Kazakhstan (Davis 2011). The East branch transports natural gas from Eastern Turkmenistan and Southern Uzbekistan to the western part of Kazakhstan (Davis 2011). Both pipelines intersect in the Western Kazakhstan, then continuing northward to the Russian pipeline system (Davis 2011).

In turn, the gas pipeline Korpedzhe-Kurt-Kui, built in 1997, is a joint project of Turkmen and Iranian governments, carrying Turkmen gas to Iran (Cohen 2006). It is the "first non-Russian gas pipeline in Central Asia", and has 
an annual transport capacity of "approximately 8.5 billion cubic meters of gas" (Cohen 2008, 5).

The South Caucasus Pipeline, also known as Baku-Tbilisi-Erzerum pipeline, is a $692 \mathrm{~km}$ gas pipeline, built in 2006 by an international consortium led by British BP and Norway's Statoil ASA, which transports natural gas from Shah Deniz, in the Azerbaijani area of the Caspian Sea, to Erzurum, in Turkey (British Petroleum website 2013). Nabucco, which was designed to connect to the South Caucasus Pipeline, is, according to Paul Belkin, "the emblem-project of the European Union in Central Asia and the Caspian region" (2008, 8). This will carry the maximum amount of 31 billion-cub meters/year of natural gas, from Central Asia and the Caucasus to the European Union, through Turkey and the Balkans, with a projected length of 3,300km (Nabucco Web Portal, 2013). According to Huseyin Seslikaya, "Nabucco comes to reinforce the strategic importance of Turkey to the European Union", being "at the center of this effort to reduce the dependence on Russian natural gas" (2008, 13). As emphasized by Haydar Efe, "Nabucco will help the European Union to diversify its sources of supply", contributing, on the other hand, to ensure that Turkey becomes the "fourth largest artery of energy supply into Europe, alongside Norway, Russia and Algeria" (2011, 127). This will open "a new way for cooperation between Turkey and the European Union", susceptible, also, to reinforce the last's ties with "Central Asia" and the "South Caucasus" (Efe $2011,127)$. Russia has, on several occasions, sought to "undermine the Nabucco project", perceiving it as an "undesirable competitor" with regard to European natural gas markets (Kardas 2011-12, 84). According to Aleksey Malashenko, "Nabucco is likely to be to Moscow more a political than an economic threat", since "natural gas provides a mean of influence into European politics" (Aze News 2011, para. 1). Nabucco's construction will tend to "significantly weaken the importance of natural gas as a strategic tool for [the policy of] Moscow" (Aze News 2011, para. 1).

In practice, Gazprom has promoted a rival project, the South Stream. Once built, it is expected that it can carry up to " $63 \mathrm{bcm}$ of natural gas per year" to supply the same markets - in Eastern Europe and in the Balkans that Nabucco is designed to serve (Gazprom 2013, para. 2). As William Engdahl regards (2011), the dispute South Stream (Russian) vs. Nabucco (backed by Washington) is, fundamentally, geopolitical. The long underwater route - about 


\section{Paulo Duarte}

$900 \mathrm{~km}$ - of South Stream and its high cost (estimated to be at least 15.5 billion euros, or 22.3 billion dollars), i.e. more than double the estimated cost of Nabucco, have promoted the widespread idea that the South Stream project is not commercially viable, and that its main goal is to annihilate potential sources of investment for a southern gas corridor that is not controlled by Russia (RT News Line 2012; Kanter 2011; Socor 2012). In this respect, António Costa Silva (2012) underlines the curious behavior of Putin's Russia, which "went to Turkmenistan and Kazakhstan to buy, for many years, these countries" gas"; and, "to try to dry the sources of supply to Western countries, offered two to three times the price that then existed"; it is necessary to consider that "Russia acquires very cheap gas from these Central Asian countries, when compared to the market price, reselling it, then at higher prices, to Europe". This is a way that allows Russians "to manage their reserves prom a point of view that benefits their interests", although it be "prejudicial to the Central Asian Republics and, also, for the European Union" (Silva 2012).

The Turkmenistan-Afghanistan-Pakistan-India gas pipeline (TAPI) is another important logistical infrastructure at the regional level. According to Rainer Palau, "the TAPI project has been debated for nearly two decades [even though it has not yet entered in phase of construction]" (Civil Military Fusion Center, 2012: 5). It is estimated that the gas pipeline will come to significantly contribute to "enhance energy security in South Asia", to provide an "important source of revenue" to the Afghan government, and to "promote regional integration" (Civil Military Fusion Center 2012 5). Likewise Central Asia Oil Pipeline, TAPI will transport natural gas from Turkmenistan to Afghanistan through the Indian city of Fazika, on the Indo-Pakistani border (The Tribune 2013). According to Tridivesh Maini and Manish Vaid (2013), there are some obstacles to TAPI's construction, such as New Delhi's apprehension regarding the project's security after the withdrawal of U.S. forces from Afghanistan, in 2014; as well as concerns about the ability of Pakistan to ensure the pipeline's safety. Indeed, these factors may "contribute to the loss of interest on the part of the Asian Development Bank in supporting the project" (Maini and Vaid 2013, para. 29).

In addition to the oil and gas pipelines already mentioned, many other (some in operation, other in construction phase, or even as mere projects) will 
not be addressed in the framework of this dissertation since they are not as strategically important as those already listed. In the "black gold" diplomacy, there are, in the background, constraints, interests concerned, preferred oil routes and others to avoid. All these aspects are inscribed in the logic of the New Great Game, which is not restricted to competition for oil and natural gas: in fact, "the pursuit of economic influence is often linked to the desire for political influence" (Edwards 2003, 86). Raquel Freire (2012) shares, similarly, with this view by emphasizing that the New Great Game in Central Asia "is not reduced to a mere contest for control of energy routes", since "there is a whole series of components" that should be addressed. Nevertheless, the energy dimensions still assume an extraordinary weight in this New Great Game, counterbalancing, for example, potential military and political "weaknesses", as highlighted by Heitor Romana (2012) in relation to the Russian strategy to contain China. The author, who admits to keep talks with "several Russian scholars", explains that they feel that "militarily and politically, Russia has neither the ability nor the willing to compete with the Chinese for Central Asia's control", being "preferred to play the game in a different manner" (Romana 2012). As an example, Heitor Romana (2012) specifies that "in the energy field", Moscow intends that "the supply of Central Asian oil and natural gas to China continues to be conducted by the Russians, for the Russian companies to control in source the production of the oil and gas exported to China". This is the case of "Gazprom" and "Rosneft", which "seek to do this" though, for example, the creation of "joint ventures with local companies" (Romana 2012). In a process which "knowledge is Russian", and in which "Russia does not directly provide natural gas and oil to China", Moscow can benefit, nonetheless, for "participation in state enterprises in these countries" (Romana 2012).

\section{The intricacies of competition}

The global financial crisis and the theory that water will be one of the next sources of conflict have served, in part, "to hide an extremely important global energetic game silently been played" (Vishwanath 2010, para. 1). This "game" consists of a fierce contest for control of Central Asia's oil and natural gas reserves (Pop 2010). With the discovery of new reserves in Turkmenistan and Kazakhstan, along with the already known in Azerbaijan, the region has 


\section{Paulo Duarte}

transformed itself into an "important energetic arena" (Vishwanath 2010, para. 1). On one hand, we have "the Western powers headed by the United States, strongly dependent on oil and natural gas issues", and, on the other hand, "the emergence of new competitors, such as China and Russia" (Vishwanath 2010, para. 1). Add to this equation Iran, which aims to become a regional power (Peterson 2013).

This region, which transcends political boundaries and ethnic lines, "is a new area of competition between the old and new competitors", and "the game will be played in the form of energy conduits from Central Asia to the rest of the world, through routes still under discussion" (Vishwanath 2010, para. 2). Each competitor seeks however, to defend its preferred route. Turkmenistan, Kazakhstan and Azerbaijan are all isolated states and, therefore, dependent on neighbors to sell its oil and gas (Pop 2010). From a historical point of view, oil and natural gas has flowed through Russia to Europe and other destinations, being that Moscow prefers to maintain the status quo, controlling the energy resources' sales to European markets (Lande 2011). In turn, Iran wants to change this trend, making the resources to flow south through its territory and be exported "to the whole world from the Persian Gulf" (Vishwanath 2010, para. 3). China, for its turn, which proposed to build $3,000 \mathrm{~km}$ of pipelines since the Caspian, going through Kazakhstan, started to build smaller lines to first support its economy and to come to supply other Asian economies (Indeo 2010). Ideally, "the United States, which does not have direct access to [Central Asian] oil and natural gas fields, aims that [these] resources reach open markets without being subjected to the conditioning of China, Russia or Iran" (Vishwanath 2010, para. 4).

On the outskirts of this game lies Turkey. Enjoying a strategic location, "Turkey stands to gain as a country of transit of energy to Europe, and, above all, to Asia" (Vishwanath 2010, para. 6). It could be extremely useful and prudent, in the long run, for the other players, to realize the potential of this stable country and involve it in future negotiations (Stevens 2009). It is also very important to recognize that Asia will be the major energetic market in the next decades, and that any country that has a participation in the control of the energy flux to the Asian economies will have a share in the control of future markets (Lande 2011). A route through Turkey has several advantages over 
other routes (Locatelli 2010). Benefitting from its good relations in the region, Turkey could negotiate more strategically and politically viable routes than the ones that would cross Russia or China (Locatelli 2010). Oil and gas dispatched through Turkey can be sent to anywhere in the world, what "is likely to offer an alternative to any Iranian monopoly in the Persian Gulf" (Vishwanath 2010, para. 7). A trans-Caspian oil pipeline from Turkmenistan and/or Kazakhstan to Turkey presents "less political complications than any other route, even though financial and environmental aspects raise serious questions" (Vishwanath 2010, para. 7). In turn, Turkey could serve up from its positions and influence to ensure that the region does not become a mere stage/scenario in this energy game, and that the equilibrium of power be maintained (Boonstra et al 2010).

Given its inner nature, Central Asia depends on long distance conduits capable of transporting its oil and natural gas to international markets (Liao Xuanli 2006). Previously, soviet pipelines existing in the region led almost all to Moscow (Morse 2009). The control over this infrastructure continued to provide the Russians influence over the transit of oil and natural gas from the region, even after the collapse of the Soviet Union (Magen and Bagno-Moldavsky 2010). However, Western investments in oil and natural gas would also generate new pipelines that are not controlled by Transneft (on oil), or by Gazprom (on gas) (Magen and Bagno-Moldavsky 2010). It is the case of the Caspian Pipeline Consortium, "supported by international oil companies (led by Chevron), by Kazakhstan and by Russia", which transports oil from Western Kazakhstan to the Russian Black Sea coast (Chow 2012,3). It is also the case of Baku-Supsa and Baku-Tbilisi-Ceyhan pipelines, "supported by Western oil companies (led by BP) and by Azerbaijan", carrying oil from Azerbaijan to, respectively, the Georgian Black Sea coast and the Turkish Mediterranean coast (Chow 2013, 3). And it is also the case of South Caucasus Gas Pipeline, that "transports natural gas from Azerbaijan, through Georgia, to Turkey", which will be expanded in the Shah Deniz deposit's next phase of development (Chow 2013, 3-4). These new pipelines decreased Russian control over the flow of oil and natural gas coming from the Caucasus and Central Asia, and contributed to achieving the 90 s objectives, which consisted of providing more economic options to the region, allowing the production of oil and natural gas to flow freely into international markets (Morse 2009). 


\section{Paulo Duarte}

When the Soviet Union collapsed, in 1991, China was about to go from and exporter of oil to an importer of it. The country was a "late player in the race for Central-Asian oil and natural gas" (Chow 2013, 4). At the time, the best opportunities for exploration had been acquired by Western companies, such as the deposits of Tengiz, Karachaganak and Kashagan, in Kazakhstan, and the fields of Azeri-Chirag-Guneshli and Shah Deniz in Azerbaijan (Magen and Bagno-Moldavsk 2010). The Chinese have sought to recover, since then, from this delay (Collins 2009). In this sense, Chinese energy companies have been investing in oil and natural gas worldwide, with Central Asia being an important card in the Chinese energy deck (Duarte 2012). The "[Chinese NOCs] hold about $30 \%$ of Kazakh oil, although this originates from smaller deposits than the ones operated by Western companies, and control, for now, the only onshore concession in Turkmenistan" (U.S. House of Representatives Committee on Foreign Affairs 2013, 4).

Chinese leaders have proved favorable to the construction of terrestrial oil and gas pipelines as a way to circumvent their extraordinary dependence on energy imports, which are mostly operated by sea (Swanstrom 2011). Due, in part, "to a certain frustration" in dealing with Russia in the field of oil and gas, "Beijing has prioritized the construction of energy infrastructure from Central Asia, such as an oil pipelines from Western Kazakhstan to gas pipelines from Turkmenistan, going through Uzbekistan and Kazakhstan, to China" (Chow 2013, 4). The Middle Kingdom has overtaken Russia as the "largest importer of Turkmen gas", being expectable that its imports "will double or triple in the coming years" (Chow 2013, 4). Note, in relation to Turkmenistan, that this is "the country that has been the target of the fiercest competition at the global level in regard to gas resources" (Feng Dan 2010, 5). Similar to other Central Asian Republics, "currently Turkmenistan has been promoting cooperation with foreign partners in the natural gas sector" (Feng Dan 2010, 9). In a certain way, "cooperation will tend to help Ashgabat to eliminate Russian monopoly over its natural gas; on the other hand, cooperation may help the country to achieve a balance between the main actors and to maximize its economic gains when stimulating competition between buyers/investors" (Feng Dan 2010, 9). Moreover, "the competition between Russia, Europe and the United States, regarding the construction of pipelines to Turkmenistan, can effectively 
enhance the status of Turkmenistan in international relations, which is likely to increase its bargaining power (on the natural gas prices level) in future negotiations with Russia" (Feng Dan 2010, 9).

In the opinion of Edward Chow, "another competitor, increasingly important, with regard to Central Asian oil and gas, is India" (2013, 4). In fact, "as the Chinese population growth slows and its population ages, it is estimated that India's energy demand will increase more rapidly than the Chinese, within a decade" (Chow 2013, 4). Although it has a better location than China to get oil and natural gas from the Persian Gulf, India also would like to diversify its imports, including on these the supplies with origin from Central Asia (Chow $2013,4)$.

Note that "the concept of wars over energy resources is something, for times, exaggerated" (Chow, 2013: 5). Conflict usually delays investments in large scale for many years. It is a fact that "there is competition for resources in Central Asia, as, indeed, in other parts of the world as well" (Kucera 2013, para. 4). In this respect, Newtimes.az underlines that "however, the rivalry between Western, Russians, Chinese and Indian [oil] companies is unquestionable" (2013, para. 5). Nevertheless, "what should worry specialists is not so much the question of the possible occurrence of war over these resources, but more if the competition around them is guided by rules, without political coercion or nontransparent business practices" (Chow 2013, 5). Since rules of competition are fair, "the various oil companies interested in Central Asia can compete in a healthy way", being that "this form of competition might be benefic in terms of promoting economic efficiency for the benefit of all stakeholders involved" (Chow 2013, 5).

Multilateral cooperation in the energy sector is benefic for "economic development, energetic security and regional stability" (Feng Dan 2010, 10). In the future, "China, Russia and the Central Asian Republics should take the maximum advantage of markets and their resources to expand and deepen cooperation in the gas sector, from which cooperation in other sectors can be further promoted and extended in order to achieve a common and balanced development" (Feng Dan 2013, 10). Despite their diverse interests and economic status, "it is unlikely that Beijing and Moscow will be involved in a "fierce' confrontation in relation to the hydrocarbons from Central Asia" (Yenikeyeff $2011,75)$. On the contrary, there are indications that Russian and Chinese 


\section{Paulo Duarte}

companies cooperate relatively well at the corporate level. For example, "Lukoil and China National Petroleum Corporation (CNPC) have been involved in the development of the Kumkol deposits in Kazakhstan and in the gas resources of the Aral Sea in Uzbekistan" (Yenikeyeff 2011, 75).

\section{Final Notes}

The observation of the essence of competition around energy resources, such as oil and natural gas, and the respective assessment of its impacts are complex, however, according to Edward Chow, "it is likely that in Central Asia the control of water resources present a greater propensity to lead to a direct conflict than oil and natural gas" $(2013,5)$. Attention is drawn to other difficulties that result, as put by Neil Brown, "from the lack of consensus on dividing the Caspian", divergences likely to "directly affect Central Asia" (2013, para. 10).

It is noted that "the game gas become more complicated, with multiple actors from different parts of the world" (Chow and Hendrix 2010: 40). According to Chow and Hendrix, "the principles of zero sum game apply not only to Russia, China or Iran, but also to Western governments' policy on oil and gas pipelines in Central Asia" (2010, 40). These authors fed a certain hope that "maybe in the next decade, there is more regard for geo-economics than by geopolitics" (Chow and Hendrix 2010, 40). 


\section{REFERENCES}

Badalyan, Lusine. 2012. "The Geopolitics of Pipeline Diplomacy." Center for Security Studies, 10 de outubro. Acesso em 10 de outubro de 2013. http://www.isn.ethz.ch/isn/Digital-Library/Articles/SpecialFeature/Detail/ ?ng $=$ en\&id $=153580 \&$ tabid $=1453347044 \&$ contextid 77 $4=153580 \&$ contextid $775=153575$.

Bahgat, Gawda. 2006. "Strategic Rivalry in the Caspian Sea." Presentation prepared for the Annual Meeting of the American Political Science Association, 30 de Agosto-03 de Setembro.

Belkin, Paul. 2008. "The European Union's Energy Security Challenges." CRS Report for Congress, January 30.

Branigan, Tania 2012. "China and cars: a love story." The Guardian, December 14. Accessed October $30,2013$.

http://www.guardian.co.uk/world/2012/dec/14/china-worlds-biggestnew-car-market.

Chevron. 2011. "Caspian Pipeline Consortium Marks the Groundbreaking for its \$5.4 Billion Expansion" Press Release, July 1 1, Accessed September 10 , 2013.

http://www.chevron.com/chevron/pressreleases/article/06302011_caspi anpipelineconsortiummarksthegroundbreakingforits54billionexpansio n.news.

Chow, Edward. 2013. "The Emerging Threat of Resource Wars." CSIS, July 25. Accessed September 15, 2013. http://csis.org/testimony/emergingthreat-resource-wars.

Chow, Edward, and Leigh Hendrix. 2010. "Central Asia's Pipelines: Field of Dreams and Reality." NBR Special Report 23.

Cohen, Ariel. 2008. Kazakhstan: The Road to Independence - Energy Policy and the Birth of a Nation. Washington, D.C./Stockolm: Central AsiaCaucasus Institute \& Silk Road Studies Program.

Collins, Kathleen. 2009. "Economic and Security Regionalism among Patrimonial Authoritarian Regimes: The Case of Central Asia." Europe-Asia Studies 61(2): 249-281.

Dawncom Business. 2012. "Turkmenistan pushes Ambitious Trans-Afghan Pipeline." November 18. Accessed September 20, 2013. 


\section{Paulo Duarte}

http://dawn.com/2012/11/18/turkmenistan-pushes-ambitious-transafghan-pipeline/.

Dellecker, Adrian. 2008. "Caspian Pipeline Consortium, Bellwether of Russia's Investment Climate." Institut Français des Relations Internationales Russia/NIS Center 31.

Demir, Idris. 2012. "Strategic Importance of Crude Oil and Natural Gas Pipelines." Australian Journal of Basic and Applied Sciences 6(3): 8796.

Duarte, Paulo. 2012. "China looks to Central Asia." Boletim Mundorama 63.

Edwards, Matthew. 2003. "The New Great Game and the new great gamers: disciples of Kipling and Mackinder." Central Asian Survey 22(1).

Egorov, Oleg. 2011. Personal Interview. Almaty.

Engdahl, F. William. 2011. "Moscow's High Stakes Energy Geopolitics."

Voltaire Network, November 15. Accessed November 02, 2013. http://www.voltairenet.org/article171902.html.

Fonseca, Pedro. 2011. Personal Interview. Lisbon.

Freire, M. Raquel. 2012. Perosonal Interview. Coimbra.

Gazprom. 2013. "South Stream." Accessed October 30, 2013. www.gazprom.com/about/production/projects/pipelines/south-stream/

Greenwald, Igor. 1996. "Buffeted by Big Powers, Central Asia Gravitates Closer to Russia's Orbit." The Christian Science Monitor, March 19. Accessed September

05 , 2013. http://www.csmonitor.com/1996/0319/19011.html.

Indeo, Fabio. 2010. "Russia and China in Central Asia: growing geopolitical competition." ISPI Policy Brief 199.

Indeo, Fabio. 2011. "The Concept of a Greater Central Asia: Perspectives of a Regional Approach." CASI Working Paper. Apresentado na First Annual CASI Conference, Outubro, University of Camerino.

Kanter, James. 2011. "European Natural Gas Pipelines Plagued by Uncertainties." The New York Times, June 13. Accessed September, 18.

http://www.nytimes.com/2011/06/14/business/energyenvironment $/ 14$ pipeline.html?pagewanted $=$ all\&module $=$ Search $\&$ mab Reward $=$ relbias $\% 3 \mathrm{Aw}_{\mathrm{w}}$ 
Kaplan, Robert. 2012. "The Revenge of Geography." Stratfor, September 05. Accessed October 10. www.stratfor.com/weekly/revenge-geography. Kleveman, Lutz. 2003. The New Great Game: Blood and Oil in Central Asia. New York: Grove Press.

Kucera, Joshua. 2013. "U.S. Congressional Committee Looks At Central Asian Resource Wars." Eurasia Net, July 25. Accessed September 13, 2013. http://www.eurasianet.org/node/67303.

Lande, Alexander. 2011. "Russia's and the EU's Energy Security Discourses on Central Asia: A Frame Analytical Approach." Dissertação de Mestrado em Estudos Europeus e Americanos, Faculdade de Ciências Humanas, Universidade de Oslo, Noruega.

Locatelli, Catherine. 2010. "Russian and Caspian Hydrocarbons: Energy Supply Stakes for the European Union." Europe-Asia Studies 62(6): 959-971.

Magen, Zvi, e Olena Bagno-Moldavsky. 2010. "The Big Game: The Great Powers in Central Asia and the Caucasus." Strategic Assesment 12(4): 115-126.

Mahdavy, Hossein. 1970. "The Pattern and Problems of Economic Development in Rentier States: The Case of Iran." In Studies in the Economic History of the Middle East, edited by M. A. Cook. Oxford: Oxford University Press.

Malashenko, Aleksey. 2011. Aze News, January 17, 2011, Disponível em: http://www.aze.az/eng.php?id=49791. Acesso em 2 set. 2013.

Morse, Edward. 2009. "Russia and the Caspian States in the global energy balance." Baker Institute Policy Report 39.

Nabucco Web Portal. 2013. Acesso em 09 de outubro de 2013: http://www.nabuccopipeline.com/portal/page/portal/en/Home/the project.

Pala, Christopher. 2006. "China Pays Dearly for Kazakhstan Oil." The New York Times, March 17. Accessed October 11, 2013. http://www.nytimes.com/2006/03/17/business/worldbusiness/17kazakh . html?.r=0.

Pop, Ionela. 2010. "China's Energy Strategy in Central Asia: Interactions with Russia, India and Japan." UNISCI Discussion Papers 24.

Romana, Heitor. Entrevista Pessoal. Lisboa. 2012. 


\section{Paulo Duarte}

Russia Today. 2012. "Gazprom and partners kick off construction of South Stream pipeline." December 13. Accessed October 05, 2013:. http://rt.com/business/russia-south-stream-launch-506/.

Seslikaya, Huseyin. 2008. "Energy security and Turkey." Master of Arts Thesis in Security Studies (Middle East, South Asia, Sub-Saharan Africa), Naval Postgraduate School, Monterey, California, United States of America.

Silva, António. 2012. Personal Interview. Lisbon.

Socor, Vladimir. 2012. "BP's Appraisal Doubles the Proven Reserves of Turkmenistani Gas." The James Town Foundation, July 19. Accessed October 14 , 2013. www.jamestown.org/single/?no_cache $=1 \&$ tx_ttnews $\% 5 B t t$ news $\% 5$ $\underline{\mathrm{D}=39649 .}$.

Starr, Fréderic, and Svante Cornell, eds. 2005. The Baku-Tbilisi-Ceyhan Pipeline: Oil Window to the West. Washington, D.C./Uppsala: Central Asia-Caucasus Institute \& Silk Road Studies Program.

Sultanova, Aida. 2005. "Azerbaijan opens part of oil pipeline to the Mediterranean." Washington Post, 26 de maio.

Swanstrom, Niklas. 2011. China and Greater Central Asia: New Frontiers? Washington, D.C./Stockholm-Nacka: Central Asia-Caucasus Institute \& Silk Road Studies Program.

The Business Year. 2011. "Time to Tap In." Accessed September 20, 2013. http://www.thebusinessyear.com/publication/article/5/232/kazakhstan $-2011 /$ time-to-tap-in.

2008. "Energy Profile of Central Asia. The Encyclopedia of Earth, 04 de setembro. Acesso em 10 de setembro de 2013. http://www.eoearth.org/article/Energy profile of Central Asia\#Turk menistan.27s_Oil_Sector.

The Tribune. 2013. “4-nation gas pipeline plan gets fresh push." February 07. Accessed October 03 , 2013. http://www.tribuneindia.com/2013/20130208/mainl.htm.

Touscoz, J. 1981. "Introduction." In Les contrats internationaux de cooperation industrielle et le nouvel ordre economique international, edited by J. Touscoz. Paris: Presses Universitaires de France. 
Tubb, Rita. 2012. “2012 Worldwide Pipeline Construction Report.” Pipeline \& Gas Journal 239(1). Accessed October 25, 2013. http://pipelineandgasjournal.com/2012-worldwide-pipelineconstruction-report?page $=$ show.

U.S. Congressional Record. 1998. "U.S. Interests in the Central Asian Republics." Hearing before the Subcommittee on Asia and the Pacific of the Committee On International Relations.

U.S. Energy Information Administration. 2013. "Kazakhstan." September 04. Accessed November 18, 2013:

http://www.eia.gov/countries/analysisbriefs/Kazakhstan/kazakhstan.p df.

U.S. Energy Information Administration. 2008. "World Oil Transit Checkpoints: Malacca." U.S. Department of Energy, Janeiro. Acesso em 06 de outubro de 2013: http://www.eia.doe.gov/cabs/World Oil Transit Checkpoints/Malacc a.html.

U.S. Energy Information Administration. 2013. "Turkey." Febuary 01. Accessed October 10, 2013. http://www.eia.gov/countries/countrydata.cfm?fips $=$ tu.

Vilar, Emílio. 2011. Personal Interview. Lisbon.

Xuanli, Liao. 2006. "Central Asia and China's Energy Security." China and Eurasia Forum Quarterly, 4(4): 61-69.

Yenikeyeff, Shamil. 2011. "Energy Interests of the 'Great Powers' in Central Asia: Cooperation or Conflict?" The International Spectator: Italian Journal of International Affairs 46(3): 61-78.

Yevgrashina, Lada. 2005. "Baku-Ceyhan Pipeline Opens to Caspian Oil." Moscow Times, 26 de maio. 


\section{Paulo Duarte}

\section{ABSTRACT}

This article analyzes some paradigmatic cases of tension between conflict and cooperation, limited cooperation and difficulties in initiating processes of cooperation in Central Asia, particularly in terms of oil and gas, often generating rivalries that prevent significant advances in regional integration.

\section{KEYWORDS}

Oil; Natural Gas; Central Asia; Cooperation and Conflict. 



\title{
THE POLITICAL ROLE OF THE UNITED STATES IN THE ARGENTINEAN DEFAULT
}

\author{
Roberto Miranda ${ }^{1}$
}

\section{Introduction}

The objective of this work is to analyze the participation of the United States of America in the restructuring of the Argentinean debt after the December 2001 crisis. Most part of studies and researches on the situation faced by the Latin American country is focused on unraveling the economic causes and mechanisms that led this country to declare the greatest suspension of debt disbursements of its history. There are many points of view and debates based on this focus. In our case, the perspective is different. We consider that the U.S. had much more to do with the Argentinean meltdown and its resolution.

During the 1990s, the U.S. had flattered Argentina for its economic conduct inspired by the Washington Consensus. However, this praise fell apart when the American economy entered recession in 2000. Starting from this moment, the discourse and actions, especially after George Walker Bush took office, were centered on leaving Argentina to chance considering the country as the sole responsible for its own financial crisis. In this sense, it was an unfavorable external scenario for Argentina, and its dependence on the U.S. was flagrant. The dependence was so important that when the U.S. administration left its indifference behind and decided to be an active part of the narrowing of the default, playing a strong and plain role of political force, the Latin

1 Member of the National Council of Technical and Scientific Research (Argentina). Professor at Universidad Nacional de Rosario (UNR) and Universidad Nacional de La Plata (UNLP). E-mail: robertoxmiranda@yahoo.com.ar. 
American country was able to recover its economic situation. It coincided with a benign change of the international context due to the rise of commodities' prices.

\section{A Dysfunctional Intention}

Argentina, as most part of Latin America, has a structural dependence on U.S. based mainly on the strategic-military dimension, which was very evident during the Cold War and reverberated on the economic-commercial and political-diplomatic dimensions. This structural dependence endured the globalization era and, amongst other questions, took its toll in the financial level through the U.S. or an interposition of the multilateral channels of credit. In the Argentinean case, the aforementioned dependence was strongly enforced by the political alignment between Buenos Aires and Washington, boosted after 1989 by the Carlos Menem administrations. Menem's successor and rival, Fernando de la Rúa, was not able to get rid of this dependence and his run ended during the 2001 crisis $^{2}$.

The Argentinean default of 2002 was not a subject related to the strategic-military plan. It was comfortable for the U.S. to appeal to the rule that affirms that each question or thematic area must be solved according to its own logic, independently of political rationality. In this sense, it was understood that the problem of Argentinean debt should be solved through financial $\operatorname{methods}^{3}$. Except for the distances, it was a kind of emulation similar to the attitude adopted by Great Britain in 1890. Back then, the British government denied political interference to finish the Argentinean crisis of the Baring Brothers Bank, when some interventionists of London demanded Robert Gascoyne-Cecil (Marquees of Salisbury) administration a state action in the

2 The Argentinean 2001 crisis had its political and institutional features, but it was primarily financial. It was felt in what was called "the crisis periphery", that is to say, emerging economies that absorbed the volatility of determined capital fluxes originated by other countries of similar condition, and it was the problem's epicenter. See Jadresic, Schmidt-Hebbel and Valdés, "Crisis financieras internacionales, prestamista de última instancia y nueva arquitectura financiera internacional," 359-391.

3 According to Jim Saxton (2003), from U.S. Congress Joint Economic Committee (JEC), Argentina entered recession in 1998 and it was facing in the end of 2001 it was facing "authentic depression". It was due to "poor economic policies that converted a common recession into depression". 


\section{Roberto Miranda}

Latin American country. The Foreign Office neutralized these demands pointing out that the problem between Baring and Argentina should not be solved through political means, but through the rules afforded by the financial logic.

The U.S. had recurred to the aforementioned rule, not only because of its complicity with the Argentinean meltdown, but also because of its very own mid-2000 economic crisis that resulted in a recession, after many years of bonanza. It was not an entanglement of magnitude comparable to the 1974 or 1981 crisis. Nonetheless, three quarters with negative growth were registered, affecting the international financial system ${ }^{4}$. The economy had over-expanded itself, there was an undetermined growth of the ICT industry and corruption seized big corporations like energy company Enron Corporation or the telecommunication enterprise WorldCom, which went bankrupt ${ }^{5}$. The American crisis was the rupture of the 1990 s power alliance between Argentina and the U.S.' key feature ${ }^{6}$. In this context, the international conjuncture became adverse for Argentina, and the hegemon's indifference concerning the critical situation that affected the Latin American country was a more than sufficient display $^{7}$.

However, once the American administration reoriented its economy, it changed its attitude towards Argentina. It fathomed the high international vulnerability of this country. Nevertheless, Washington was not specifically interested in Argentina's destiny, but in hemispherical stability. The Latin American state's crisis was thereby analyzed through strategic lenses in order to both preserve the U.S. geopolitical interests in the region and blockade an inception of disaster in the world economic system. The initially intended rule

${ }^{4}$ According to Alicia Girón (2002), the Al-Qaeda attacks of 9/11 "fastened the uncertainty process not only in the United States, but in the international financial market", joining the global economic recession.

${ }^{5}$ During the 2000 crisis, one must also consider the vertical fall of interest rates. See Gutiérrez, "El papel de la industria de las TIC: recesión y recuperación en Estados Unidos y México," 45-77.

${ }^{6}$ Like affirmed by Guillermo Calvo (2009), in a certain way there was a "financial contagion", which is the "most common mechanism through which a local contingency turns into a global or systemic crisis".

${ }^{7}$ Argentina, like Brazil, was a highly indebted country. It was not casual that the American recessive crisis took its toll in the economies of countries that, according to Roberto Frenkel (2008), were in "financial snare, with high country risk taxes, slow growth and huge external financial fragility". 
that affirmed that each question or thematic area should be solved according to its own logic was consequently broken. To leave the indifference firstly propelled to the Argentinean case aside and to subordinate the International Monetary Fund (IMF) to its own objectives was fundamental. One more time Argentina felt the vigor of the dependence on the U.S., as it happened when enduring the effects of the North American recessive crises just to be assisted by Washington due to its strategic needs.

\section{The change of the American decision}

The American participation of the negotiations related to the external debt of Argentina started when the White House decided to oppose what was sustained by the Secretary of the Treasure, Paul O'Neill. The secretary had affirmed that the aforementioned negotiation should befall between the indebted country and IMF, under technical criteria and without political intromission. In order words, a debate within the financial rationale. O'Neill's aim was to tear U.S. apart from the Argentinean case foisting the responsibility to solve the case to IMF because of Washington's responsibility for the development of the 2001 crisis in the Latin American country, among other reasons - like aforestated. Hence, O'Neill vetoed the Argentinean Minister of Economy's proposal to justify the restructuring of the debt deadlines through political criteria. The minister was Jorge Remes Lenicov.

O'Neill's ground zero was not easy to achieve. IMF was divided between opinions on the Argentinean case. Some clerks of the international fund echoed the opinion of the influent economist Rudiger Dornbusch, who affirmed that IMF should "intervene" in the economic conduction of Argentina due to its institutions' weaknesses. At the same time, other IMF officials aligned with the ideas of Fernando Losada, from the New Yorker ABN Amro Bank, who relished the possibility of lending Buenos Aires the necessary amount for it not to deepen its default. In spite of these positions, O'Neill relied on a very important ally, Anne Krueger, IMF first deputy managing director. With similar goals to O'Neill's, Krueger wanted to overshadow the role played by IMF in Argentina's indebtedness, conceding Buenos Aires total responsibility for the halt of 


\section{Roberto Miranda}

payments. For these reasons, parallel to $\mathrm{O}^{9} \mathrm{Neill}$, she wanted a strictly technical negotiation, without any political transactions.

Krueger's position in favor of a technical negotiation, added to the stubbornness of Remes Lenicov, betting in a political agreement, meant that the relation between Argentina and IMF had entered a paralysis with no return (Torres 2010, 88). From this moment, the White House was rippled by concern not because of the economic and political future of Argentina, but because of the possibility that its default could affect the regional and provoke unpleasant international consequences. As Eduardo Duhalde, president of Argentina at that point, was not well regarded by Washington, Bush decided to change O'Neill's official position on the Argentina's debt deadlines. It was an important shift, since the U.S. opted to conduct the negotiation between Argentina and IMF in order to avoid greater damages. It implied ignoring Remes Lenicov's attitude, putting Duhalde on the backburner and supporting the appointment of Roberto Lavagna as Minister of Economy, in whom Washington trusted to reach a satisfactory conclusion.

The U.S. administration, echoing the strong pressure made by international bankers, imposed as a primary condition the derogation of the Economic Subversion Law for Argentina, which was successfully achieved ${ }^{8}$. The brokers based themselves on the rationale that this act impeded the functioning of the national financial system according to the international rules. Such bankers obviously relied on IMF bureaucrats that, on the other hand, claimed the deprecation of the aforementioned decree since it caused juridical insecurity for investments. In fact, both banks and IMF aimed covering the complicity they had during the halt of payments mainly through "financial shielding" actions, the so-called "megaswap" for postponement of debt deadlines and other

8 The Economic Subversion Law was from 1974 and broadly stipulated sanctions for people who economically damaged the country. In 2002 some judges applied this act to prosecute bankers for the so-called "financial play yard". The government also had to reform the Bankruptcy Act that, by preaching productive and creditworthiness emergency, was able to readjust debtors and the debt of the private sector. On the other hand, it had to close the fiscal agreement with main provinces, since it was one of the requirements made by IMF. It is also worth to mention that sectors of the Argentinean entrepreneurship supported the derogation of the Economic Subversion Law, arguing that it impeded the procurement for credits of the International Finance Corporation of the World Bank. 
actions that ended up structurally damaging the country's economy instead of stabilizing it.

The American participation in the negotiations was not only based in the Argentinean compliance with abolishing the Economic Subversion Law. It was also because Duhalde promised to call elections in order to avoid an extension of his interim tenure, which was fulfilled. Further, the aforementioned support was possible for other reasons. One of them was the White House decision to tear O'Neill apart from the Argentinean case. A second one was the improvement in the commercial and diplomatic relations between Washington and Buenos Aires ${ }^{9}$. A third facet was the tacit consent that the U.S. Treasury Department afforded to the "theory of misrepresentation" sustained by Lavagna facing the actions and declarations made by Director of the Western Hemisphere Department of IMF, Anoop Singh, who was intensely involved with the future of the Argentinean assets ${ }^{10}$.

However, not only these reasons were related to the American choice to lead negotiations between Argentina and the IMF. There were also three international issues that U.S. had to bear in mind to increase their participation in the talks initiated by the Latin American country in order to reschedule debt deadlines. One issue was the fall experienced by stock markets in Chile and Mexico in June 2002. Another was linked to Brazil's stability, as the White House supported an IMF loan of 30,000 million to that country in September 2002 , the largest credit ever from the institution, in "support of the economic and financial program"11. A third issue, very important indeed, was the pressure exerted by Spain and France on the G-7, which softened the U.S. perspective on the Argentine default and, in parallel, allowed Lavagna to introduce a political

\footnotetext{
${ }^{9}$ Robert Zoellick, Trade Representative, for example, made clear to Chancellor Carlos Ruckauf that U.S. was going to include Argentina in the "Generalized System of Preferences", which benefited exports to the American market through very low duties, or even absence of any tariff.

${ }^{10}$ Singh was alienated from the Argentinean case and replaced by John Thorton.

11 See IMF Bulletin, v. 31(17). Available at: http://www.imf.org/survey. Accessed March 20, 2009. It is also worth reminding that Brazil was in electoral campaign, and that Luiz Inácio Lula da Silva was the most favorite candidate to enter Palácio do Planalto. One must add that not only the U.S. was interested in the economic stability, but also France.
} 


\section{Roberto Miranda}

element in the technical atmosphere through which the negotiation of the agreement with the IMF was unfolded ${ }^{12}$.

Besides all that has already been stated, there was a very overwhelming situation, which was the recovery that Argentina's economy was experiencing since 2002 thanks to the growth in world trade operated in the first and third quarters of that year. Thereby, U.S. finally interjected for Argentina and the IMF to stamp the provisory agreement of January $2003^{13}$. On the one hand, U.S. pushed the international body to postpone the deadlines Argentina carried, and, on the other, it pressed the director, Horst Köhler, to isolate the bureaucrats from the talks. For Washington the recovery of Argentina's economy functioned as a guarantee, while focusing their expectations on the next government. Lavagna had succeeded in changing the axis of negotiation and simultaneously raised the final restructuring of the foreign debt question in other negotiations, under different circumstances, of less vulnerability to Argentina (Miranda 2003).

\section{The Lavagna-Taylor Axis}

The beginning of the Néstor Kirchner administration, in May 2003, caused a positive attitude of the U.S. towards Argentina. If Washington did not know the brand new president enough in terms of political experience, the American government bet on his assumption since it understood that the end of the Argentinean default was more feasible with him. The visit made by Secretary of State, Colin Powell, to Buenos Aires right after Kirchner entered the Casa Rosada was a display of the U.S. political support for Argentina to commit itself with IMF in the negotiations for a definite agreement on the reschedule of the debt deadlines. In order to make that possible, the White House proposed "a

\footnotetext{
12 The Spanish and French objectives was about preserving their companies' interests, which were much beneficiated by the 1990 s privatizations.

13 In October 2002, Alan Larson, Undersecretary of State for Economic, Business and Agriculture Affairs, anticipated the American decision to press IMF for creating a transition program for Argentina.
} 
cooperative and bilateral relation", which - concretely - implied on a direct backing for Argentina before the international financial organization.

Bush did not want complications within the region and sought harmonizing its links to it because its agenda was centered in other global areas. On the one hand, he met the Brazilian president Luiz Inácio Lula da Silva in Washington in order to ratify once more the historical and strategic alliance between the hegemon and its pivot. It was not strange that on the occasion the American president stated that Brazil was "an incredibly important part of peaceful and prosperous North and South Americas", thanks to the "increasing and vital" relations between both countries. Hence, the White House was not strange to the underpinning IMF unreservedly loaned Brazil in 2002, as aforementioned. In this case, the U.S. government had no doubts about supporting Brazil for its strategic condition. On the other hand, in the frame of aiming a harmonic climate within the region, the American support for Argentina was also possible because two officers that were reticent on making concessions for the Latin American country had left their posts. They were O'Neill and the president of the National Economic Council, Lawrence Lindsey ${ }^{14}$.

Kirchner's answer to this new stage opened within bilateral relations was opportune. The president of Argentina accepted the maintenance of Lavagna in his administration because, among other reasons, it was the intention of John Taylor, Undersecretary of the Treasure for International Affairs, in order to conserve the negotiation structure that had created the provisory agreement of January 2003, and through which a definite partnership between Argentina and IMF could be built. Indeed, Taylor only believed in Lavagna as a valid interlocutor to deal with the relations between Argentina and the international fund. On the other side, the American officer regarded as highly favorable the legislative and entrepreneurial support constructed by the Argentinean minister during the interim mandate of Duhalde and that represented a stronger political solidity than the very president during

14 See Edmund Andrews, "Big Banks Step up Efforts against IMF Debt-Relief Plan", The New York Times, December 19, 2002. 


\section{Roberto Miranda}

Kirchner's outset. It was not everything, however. The Undersecretary of the Treasury enormously valued Lavagna's compromise to start negotiations with the private creditors of bonus in default in order to forge a sustainable proposal.

This compromise implied that Taylor obtained a good position in the debate generated inside IMF concerning the Argentinean case. Moreover, it meant a new step backwards for the bureaucrats of the international fund, who demanded a technically very severe and long-term agreement, a point Argentina could not admit, among other questions. Thus, the Undersecretary of the Treasury consolidated his conduction of the Argentina-IMF relations, which derived the recognition of the U.S. as the intervening variable in the solution for the problems caused by the default of the Latin American country. On the other side, to entrust the IMF bureaucracy was a more than important task for Lavagna, and only Taylor was able to do that, practically finishing technical criteria in the negotiation.

During the talks, different questions emerged and they deserve to be stressed. One was the power accumulated by the Argentinean Minister of Economy thanks to the political support guaranteed by the Undersecretary of the Treasury. For example, he removed the Chancellery from spaces that would normally be reserved for it. At the same time, the constraint of the external agenda of Argentina because of the debt question erased the importance of other topics linked to the foreign relations of the country. However, the most relevant fact was the main role played by Lavagna during the negotiations, which produced a kind of intragovernmental dispute between him and the president of the Central Bank, Alfonso Prat Gray, quickly replaced by Martin Redrado in September 2004, and also between the minister and Kirchner, along with his Minister of Federal Planning, Julio de Vido. It must be considered that Taylor systematically supported the Minister of Economy during this internal struggle of the Argentinean administration, which was a substantial backing at that time.

Another question to be stressed was the international context through which Argentina has passed from 2002 onwards, which became favorable. The rise of the commodities' prices, which increased $224 \%$ at that year if compared to 1972, generated an interesting boost of Argentinean foreign exchanges, which contributed, as mentioned before, to a quick recover of the national economy. 
The exports, which represented roughly US\$25bi in 2002 , leapt up to US\$30bi the following year, mainly through cereals, animal food, seeds, petroleum and products, and vegetable oils (Berrettoni and Polonsky 2011). The global demand for food, especially for soy, transformed Argentina into an agricultural power, positioned as the third soy exporter between 2002 and 2005, behind U.S. and Brazil, according to the Food and Agriculture Organization of the United Nations.

A third important question is the American intention to consider Argentina as a secure ally for themes of U.S interest. Washington thought that through facilitating the Argentinean exit from the default, Argentina would respond favorably to some requirements made by the White House. For example, Bush administration believed that Argentina would support the American intervention in Iraq, would accept the Free Trade Agreement for Americas, would sustain an eventual military presence of U.S. in the Triple Frontier and would start an estrangement from Cuba and, afterwards, Venezuela. Things happened the other way, though, and Kirchner dismissed every single expectation. After all, and beyond the American decision-makers, the only question that worried Taylor was the Argentinean exit from the default, which was what Bush enrolled him for, and it dominated the bilateral links.

\section{The negotiation}

The negotiation showed that its hardcore consisted of the Lavagna-Taylor axis. The talks between Kirchner and the IMF bureaucrats was not decisive for the negotiation's developments. The Argentinean president heavily criticized the behavior of the international fund during the 1990s until the 2001 crisis, mainly because of the erratic and damaging character of this institution towards the country. However, Kirchner's discourse against IMF was directed for domestic politics, reason why some analysts and researches of the ex-president's foreign policy hypothesize that this rhetoric was used solely for strengthening its government. There was a special reason for this process, which was to bind Argentinean society around an assertion that concerned the sovereign zest, thus increasing the internal legitimization of the national government after the meager electoral results obtained by Kirchner to access Casa Rosada. 


\section{Roberto Miranda}

In spite of the aforementioned motivations, Kirchner's discourse sensitized IMF bureaucrats, especially because the officers faced the obligation to preserve decision-spaces that were added to the fund's structure opposite the rulers of the main country-members of the organization. That is the reason why the bureaucrats endeavored to contest the discourse that blamed them for the Argentinean debacle by minimizing the missteps made as a consequence of the application of their policies, even ignoring the support to the Menem and De la Rúa administrations. Nonetheless, it was evident that the IMF bureaucracy had lost their negotiating spaces to the American government, and Taylor had much to do with that in the Argentinean case. With Lavagna he crowned coincidences that culminated in the end of a negotiation that IMF had to accept without changes ${ }^{15}$.

The aforementioned undersecretary made three practically decisive political actions. Firstly, he quickly neutralized the pressure made by some G-8 governments that sought transmitting their citizens' demands, creditors of some Argentinean bonds in default, mainly Italy, Japan and Germany. In this frame, the task accomplished by Lavagna and his Finance Secretary, Guillermo Nielson, was of great relevance. Secondly, Taylor achieved an interministerial success by making the Assistant Secretary of State for Western Hemisphere Affairs, Roger Noriega, attenuate his negative points of view concerning the domestic politics of Argentina. Finally yet importantly, Taylor was able to silence Krueger, and thus took away her support for the points made by IMF bureaucracy, which demanded a strict and technical treatment for the Argentinean case.

Precisely after getting round the last intent made by the IMF bureaucrats concerning the primary surplus and the structural reforms that Argentina should put in practice, Taylor and Lavagna signed a three-year agreement on refinancing the capital deadlines. It was in September 2003, during the annual meeting between IMF and the World Bank that took place in Dubai, United Arab Emirates. Due to this agreement, Argentina could envisage

15 Sebastián López Cóppola, María Cecilia Tossi and Ivana Verdi (2003) understand that Argentina took advantage from the use of the reciprocal costs of the interdependent relation with the IMF. 
an immediate debt of almost US\$ 3 bi. The most remarkable point of this agreement was yet the IMF's acceptance on a primary surplus of $3 \%$ in terms of the GDP, when the bureaucrats' pretention was of $3.5 \%$ in 2004 and $5 \%$ in 2006.

Beside the agreement, Argentina made the proposal effective for private creditors on the condition that it was possible because of its sustainability. Amongst other aspects, the proposal meant that, on the one hand, a debt reduction of $75 \%$ of the nominal value related to the debt capital in default, and on the other, the non-recognition of the due dates of interests payable after 2002. The Argentinean initiative imitated the differences between Kirchner and the IMF. The Argentinean head of state disdained the critiques and pressures of the international fund, which tried to bind the refusal of bondholders to the Dubai proposal, and whose organizations were not recognized by Buenos Aires $^{16}$. Kirchner did not want to change the proposition because he prioritized the domestic politics, especially the institutional stability and the growing economy, besides considering that in 2005 medium-term polls would occur and test his political legitimacy.

Despite its political debilities, IMF wanted to canalize its questions on the Argentinean proposal once more, this time through the ministers of Finance and Economy of the G-7. For example, the Ministers Meeting of Boca Ratón, organized in February 2004, raised the same demands the international fund did, that is to say, that Argentina should allow the participation of bondholders in the negotiation of bonds in bankruptcy, and also that the country should solve the pending structural reforms. In certain moment, the compromise between G-7 and IMF menaced the scheme fostered by Buenos Aires and agreed on by Taylor. The alliance between the bureaucratic power of the multilateral

16 During the Annual Meeting of the Boards of Governors of the Inter-American Development Bank in Okinawa, in April 11, 2005, Lavagna pointed out that was impossible to negotiate with "individual groups" of bondholders. Furthermore, the round of consultations with them had been very productive because, after all, "it was necessary to let the markets speak. And the markets, with more realism than the lobby groups, have spoken favorably, with a rate of acceptance of more than 76 percent, higher than what collective action clauses require today". See Roberto Lavagna, "Address by the Governor for Argentina at the Third Plenary Session". Available at: http://idbdocs.iadb.org/wsdocs/getdocument.aspx?docnum=516885. Accessed August 07, 2010. 


\section{Roberto Miranda}

organization and the world political power was a bad sign for the conduction exerted by the Undersecretary of the Treasury concerning the Argentinean default.

Regardless of the declarations and intransigencies, Argentina launched the trade of bonds without IMF interventions in the beginning of 2005, and with a new backing from Taylor, who did not wish for anything else than a quick solution of the case ${ }^{17}$. The agreement between the American undersecretary and the Argentinean minister had prevailed, showing that the hardcore of the negotiation consisted of both actors. It is worth to mention that Lavagna had made some adjustments on which Kirchner did not agree. For example, he enhanced the Dubai proposal, recognizing the falling interests since 2001, which was an incentive for attraction of private creditors. In March 2005, the acceptance of the Argentinean proposal had reached almost $77 \%$ of the total bonds, which surpassed previous expectations. The Argentinean government regarded the as highly positive, with aims at re-entering the capital markets, which ultimately was the natural objective of solving the default.

The differences between Kirchner and the IMF bureaucracy stayed in second plan. Lavagna negotiated through political criteria linked to technical references, while Taylor sought demonstrating that the Dubai proposal was sustainable. Hence, Taylor tranquilized the pressures centered within G-8, which represented world politics and the owners of transnational capital. Most part of the private creditors could not obtain a better guarantee than the backing of an American undersecretary to an offer made by the Argentinean minister, obviously. The proposal also eased IMF, which could not oppose the stratagem developed by Taylor though this scheme was seen as a defeat by the fund's bureaucracy. The message of the undersecretary to G-8 consisted of asking for tolerance on Argentina's fate because, amongst other reasons, the market developments would benefit the proposal made by the Argentinean minister. He also added that, on the one hand, Argentina was paying debts to IMF, sometimes with reserves from the Central Bank, and on the other, that he

17 We must bear in mind that in the end of September 2004, the Securities and Exchange Commission (SEC) lifted the prohibition for Argentina to operate in the market and, therefore, approved the exchange proposal made in Dubai. 
believed Buenos Aires would deal with points that spurred the international fund, such as the tariffs of public services and the primary surplus ${ }^{18}$.

\section{The Frozen Agenda}

After making the trade, the main actors of the negotiation set apart from the triangular relations between Argentina, U.S. and IMF. Taylor left the Bush administration in April 2005 and Lavagna did the same in Argentina in November of the same year. The White House decided to decrease its participation in the connections between the Latin American country and the international fund. The U.S. regarded its compromise to stop the Argentinean default from provoking a generalized regional crisis as deeply fulfilled. The Americans understood that the IMF should deal with a smaller problem, like the bondholders that withdrew the trade, and the fund should formulate a grievance against Argentina as well. For his part, Kirchner personally headed the relation with multilateral means of credit once his electoral victory was consolidated on the legislative renewal of 2005, proportionating the political strength he needed.

The relations between Argentina and the IMF did not improve and dramatically deteriorated instead ${ }^{19}$. One question was the issue raised in August 2004 about the suspension of bilateral talks because of the non-fulfillment of the aims fixed by the agreement, and that did not surpass to preserve the trade. The struggle between Kirchner and the IMF bureaucracy was revived through this topic, from different positions to the ones they had had in the past and under a very distinct context, certainly. Nonetheless, the IMF did not cease to appeal to the political assistance of the U.S. That is what happened when the international fund's bureaucracy, contrarily to the original intention of the

18 Lavagna indicated such intention when modifying the interest rates for 2005, increasing the consolidated primary surplus with the objective to draw near the numbers asked by IMF. It must also be mentioned that in September 2004 the risk rating agencies had mentioned that it was necessary to increase primary surplus not to be on default once again.

19 According to José Fernández Alonso (2006, 86), “the policies seeking the normalization of relations with global financial agents met an increasing complexity. By then, the limitations of a policy conducted by confrontation became evident." 


\section{Roberto Miranda}

American government, pressured the White House for it to demand Argentina a peremptory solution for the holdouts, which represented a rough $24 \%$ of the total amount of bonds in default.

Randal Quarles, Undersecretary of Finances of the Treasury Department, wanted to resume the role the U.S. used to have on the issue of the Argentinean default, but he failed. The American officer intended to create an obligation for Argentina to solve the holdouts' situation before reestablishing a positive link to the IMF. In that moment, the expressions used by Lavagna during the developments of the $46^{\text {th }}$ Annual Meeting of the Inter-American Development Bank, in April 2005, had an enormous weight. In the occasion, the Minister of Economy characterized the IMF's request to solve the bondholders issue immediately as discriminatory, when in similar cases the negotiations took many years.

Besides the suspension of bilateral negotiations because of the nonfulfillment of the goals fixed by the agreement, another issue marked a breakdown in relations between Argentina and the IMF, which were the consequent effects of the Casa Rosada's decision to cancel its obligations with the aforementioned fund, in December 2005. In spite of the many critiques by the political opposition, disparate from each other in terms of arguments, the Argentinean Congress rectified the presidential decision. The payment of almost US\$ 10 bi in debt was effective for the international organization by enrolling a context that other countries, like Russia, Indonesia and Philippines, had also been part. Brazil had had an identical initiative days before the Argentinean measure, which, according to some versions, were decisions coordinated by Lula and Kirchner. For the Argentinean president, the country had achieved the "independence from the international organization".

The cancelling of the Argentinean debts with the IMF paradoxically meant the freezing of the bilateral agenda between both actors. Some analysts had been optimistic when estimating that the differences between Kirchner and the IMF bureaucracy would be overcome once the debt was settled. On the one hand, such analysts supposed that the IMF would redeem its responsibility for the 2001 crisis through this act. On the other, they believed the relief nurtured by debt reduction would provide for Argentina an autonomous space to design and execute its social and economic policies, as well as to attract investments 
without the participation of the IMF. However, the disparities persevered to such extent that the revision on the Argentinean economy made by the fund in July 2006 according to Article IV of the Constitutive Convention of the fund, the first since the cancellation of the debts, never happened again. Furthermore, the freezing of the Argentina-IMF agenda had a ricochet effect on the relations between Argentina and the U.S. What could be transmitted to Argentina by the international fund, it was through the U.S. government.

\section{In conclusion}

The non-adaptation of Argentina to the IMF patrons, the same which contributed to what ended up as the 2001 crisis, meant that the relations between the country and financial issues was made without the participation of this international fund, and this place was directly occupied by the U.S. The latter country kept the political role played when dealing with the default until a big part of the debt problem was solved. However, the position of the American government before Argentina changed from a collaborative into a litigant one, demanding the solution of issues as the negotiation with the private creditors that did not enter the bond exchanges of 2005 , in spite of the Quarles' failure.

Because of Buenos Aires' resistance, Washington kept prioritizing its strategic interests that were the axis of Argentina's structural dependence to the U.S. Notwithstanding the many coincidences between the actors in different issues of the bilateral agenda, the U.S. government limited the external actions of Argentina, which was recovering economically and achieving institutional stability. A prove of the American restrictions was the penalization of Argentina through obstacles to its access to the transnational circuit of investments, which turned out to be a reinforcement of the country's isolation from the international financial market. When Argentina rightly believed that debt relief was going to give the country a stronger economic freedom, the hegemon - in name of the international financial system - reduced its margin of international maneuver. 


\section{Roberto Miranda}

\section{REFERENCES}

Berrettoni, Daniel; and Mariángeles Polonsky. 2011. "Evolución del comercio exterior argentino en la última década: origen, destino y composición". Revista del CEI 19: 81-99. Ministerio de Relaciones Exteriores y Culto, Argentina.

Calvo, Guillermo. 2009. "Crisis financieras internacionales. Interpretación e implicaciones para la teoría y política económica". Conference at Universidad ORT. Montevideo, August 19.

Fernández Alonso, José. 2006. "La reinserción financiera como eje rector de la agenda ex-terna argentina post-default". In La política exterior del gobierno de Néstor Kirchner, Tome IV, Vol. 1, edited by Centro de Estudios de Relaciones Internacionales de Rosario, 31-88. Rosario: Editora Universidad Nacional de Rosario.

Frenkel, Roberto. 2008. "Tres notas sobre las economías de mercado emergente y la crisis financiera internacional". Iniciativa para la Transparencia Financiera, Documento n'37. Available at: <http:// www.itf.org.ar>, Accessed April 18, 2010.

Girón, Alicia. 2002. Crisis Financieras. Mexico City: Instituto de Investigaciones Económicas, Universidad Nacional Autónoma de México.

Gutiérrez, Roberto. 2004. "El papel de la industria de las TIC: recesión y recuperación en Estados Unidos y México". Análisis Económico, XIX (42): 45-77. Universidad Autónoma Metropolitana Azcapotzalco.

Jadresic, Esteban; Schmidt-Hebbel, Klaus; and Rodrigo Valdés. 2003. "Crisis financieras internacionales, prestamista de última instancia y nueva arquitectura financiera internacional". Cuadernos de Economía, 120: 359-391. Pontificia Universidad Católica de Chile.

Lavagna, Roberto. 2005. "Address by the Governor for Argentina at the Third Plenary Session". Available at: http://idbdocs.iadb.org/wsdocs/getdocument.aspx?docnum=516885. Accessed August 07, 2010.

López Cóppola, Sebastián; Tossi, María Cecilia; and Ivana Verdi. 2003. "La relación Argentina-Fondo Monetario Internacional: el uso de los 
costos recíprocos". Relaciones Internacionales, 24: 107-126. Universidad Nacional de La Plata.

Miranda, Roberto. 2003. Política Exterior Argentina. Idas y venidas entre 1999 y 2003. Rosario: Ediciones PIA.

Saxton, Jim. 2003. "La crisis económica argentina: causas y remédios”. Comité Económico Conjunto del Congreso de los Estados Unidos. Available at: $<$ http://www.vekweb.com>. Accessed February 02, 2011.

Torres, Jorge. 2010. La política exterior argentina en los tiempos del default. Buenos Aires: Dunken. 


\title{
Roberto Miranda
}

\begin{abstract}
On December 2001, due to the financial crisis, Argentina had to suspend external payments. The country started a frantic process of abandonment of default thereafter. Research about the causes, processes and mechanisms of the crisis has focused on economic issues. The present work instead considers international politics. The aim of the paper is to analyze the role of the United Sates in the restructuring of Argentina's debt. We consider the reasons, conditions, and actions developed by the hegemonic power in the relationship between Argentina and its creditors. We specially emphasize the political role played by the U.S. government, a position that the U.S. administration had no intention to assume neither before the debacle nor after the crisis started. We conclude that, despite the fact that Argentina has overcome the most difficult part of its default, the episode made evident, once more, the strong Argentine dependence towards the United States.
\end{abstract}

\section{KEYWORDS}

Argentina; United States; External Debt; Default. 



\title{
NEW INDEPENDENT FOREIGN POLICY, A MATTER OF EMPHASIS
}

\author{
Eduardo Brigidi de Mello ${ }^{1}$
}

\begin{abstract}
"It is the third war from which I flee, but it is the first in which I have the support of the Brazilian government." Lebanese citizen's account cited in Conversas com jovens diplomatas, by Celso Amorim
\end{abstract}

\section{Introduction}

Brazil's foreign policy has recovered, since 2003, the main lines of force adopted from 1930 to 1980, especially those outlined from January 1961 to March 1964. The Lula Administration emphases were the result of the renewed conception of the state as the strategic coordinator of development, as opposed to the $1990 \mathrm{~s}$ experience when the logic of the Market possessed primacy. The state has expanded and diversified public policies, arrogating central role in combating inequality, which would be a condition for democracy and growth. Externally, the structural transformations and the institutional improvement begun with the redemocratization allowed the country to consolidate its globalist strategy, to which in 2003 the protagonism emphasis was added.

This emphasis had as deontological premise the value of equality (also spoken of as social justice), present in innumerable speeches of the President and his Chancellor and promoted to key variable of the foreign policy. If the development depends on the position of the country in the international system, equality promotion demands the correspondence between internal and external

\footnotetext{
${ }^{1}$ Ambassador of the Ministry of Foreign Affairs of Brazil since 2008, worked at the embassies in GuineaBissau and Chile. Master in Political Science, UFRGS. E-mail: eduardo.brigidi@hotmail.com.
} 
approaches, which are reflected in the democratic mirror: national democracy, global multilateralism. In this sense, equality (content) and democratic legitimacy (form) are the distinctive elements that allow the comparison of this period with the Independent Foreign Policy (IFP), which is the reason to call it New Independent Foreign Policy (New IFP).

Hence, the study of the New IFP is proposed through four lines: (a) Political Multilateralism; (b) Economic Multilateralism; (c) South-South Cooperation; and (d) Equality. The first two are considered objectives; cooperation, an instrument on which they depend; and equality, the value that bases them, permeating the discourse and action. The value of equality is the idealistic component of the New IFP, added to the multilateral neorealism and the pragmatism of cooperation, in a methodological concert that aims to identify the singularity of the Brazilian performance between 2003 and 2010.

\section{Independent Foreign Policy (IFP)}

\section{Still the matter of rupture}

The IFP lasted little longer than three years, between 1961 and 1964, a time when the country's vulnerabilities rendered improbable the assumption of external risks. Even so, there was controversy concerning the debate on its alleged character of rupture with the Brazilian diplomatic tradition, having even been considered one of the accessory causes of the 1964 Coup. One has to remember that the IFP extracted legitimacy from the 1946 Constitution, whose article 4 , the only one to deal with international relations, brought the principle of the peaceful settlement of disputes, through arbitration or other ways "regulated by international security organization" of which Brazil was member.

The limited constitutional text was typical of a period of state formation, which allowed broad interpretation on tradition's constituent principles. This, however, must be depurated from its mythical elements, not being an "immovable statue", as the Aristotelian and Hegelian conceptions. It is rather the cultural inheritance of beliefs and techniques, transmitted from a generation to another, a passage in which tradition carries out the fruitful tension with creation (Abbagnano 2000; Bosi 2002). These values or techniques suffer rupture only when they are substituted by anti-values or opposed 


\section{Eduardo Brigidi de Mello}

practices (Bosi 2002), in dichotomies as pacifism-bellicism, capitalismcommunism, protectionism-free exchange.

Value, the good which is object of choice, is materialized by principles, the ground of action; they are made singular for their essence, which cannot be confused with emphasis, being the stress of the substantial nature. Hence the question: did the IFP propose the revision of the essence of the traditional principles of the Brazilian foreign policy? Did it break away from the hegemonic power in the hemisphere, the United States, to align with the opposing tradition, the Soviet communism? Did it leave the OAS and TIAR to adhere to the Communist International and Non-Aligned Movement (NAM)? Did it start to support bellicosity, entering NATO or the Warsaw Pact? Did it break the Military Agreement with the US? Did it question the United Nations Security Council (UNSC) authority and the peaceful settlement of disputes?

One could go on indefinitely, as the IFP tenets organized by San Tiago Dantas are analyzed (Dantas 1962, 6). Was it contrary to the tradition of defending the "practice of coexistence" and the "general and progressive" disarmament? "Non-intervention" and "self-determination of peoples"? To announce "foreign market expansion" and trade relations with "all" the countries? To urge the "emancipation" of the non-autonomous territories? Could one consider as rupture the defense of the endogenous formulation and control of economic plans and foreign aid? The affirmative reply to these questions would be harmful to the very tradition they seek to protect, since it would involve recognizing that such postulates-minimally sovereign-were not part of our culture.

By assuming, therefore, the conceptual precision of words as tradition, value, principle, essence and emphasis, it is possible to clarify some aspects. Take, for instance, the tradition of trade: if, since the Eusébio de Queirós Act, the traditional principle was that of the free trade with protectionist nuances, the emphasis to search for all the possible markets was, as the word indicates, an emphasis, an intensification of the essence to trade. If we defended the principle of self-determination, to abstain in the voting of anti-colonial resolutions in the UN meant a change of emphasis, not of the essence of the tradition, which was the self-determination; likewise, to support the permanence of Cuba in the OAS 
was to emphasize the principle of non-intervention, not to subvert it in its essence.

The question, however and therefore, remains: what potential of rupture would the IFP have facing an international — not to say hemisphericsystem with extreme disproportion of power over Brazil? Bipolarity restricted practical actions and made the IFP limited to symbolic actions (Amorim 2011), which is why the analysis must be concentrated at the level of the discourse, at which the principles of the Diplomacy for the Development were recovered, which had begun with the 1930 Revolution and in force until the $1980 \mathrm{~s}$ (Visentini 2004). These principles-cooperation, pacifism, nonconfrontationism-marked the formative period of the tradition, extracted from the dialectic of the liberal and autonomist lines (Cervo 2012a).

\section{Discourse and World View}

According to President Jânio Quadros, the IFP sought to overcome "the subsidiary and innocuous diplomacy of a nation aligned with worthy though alien interests" (Quadros 1961). In the political sphere, Chancellor Afonso Arinos proposed cooperation, respect to the international law and strengthening of the UN, which was the appropriate place to put forth reforms and where Brazil would keep its independent position, voting on a case-by-case basis grounded in its permanent objectives (Arinos 2001).

Despite the ideological affinity, Brazil was not tied to the "Western bloc", for its "legal commitments" were limited to "continental bindings": UN, OAS, TIAR and Brazil-US Pact of Military Assistance (Arinos 2001, 239-240). The "independent" adjective, in turn, brought the challenge to the Cold War bipolarity, in order to extend the area of "own" initiative and responsibility and to contribute for a peaceful and fair order. From it derived the condemnation of war, complemented by the idea that "political freedom" also required "social justice and economic equality" (Dantas 1962, 18-19).

In the economic realm, the IFP should contribute to the increase in exports and, thus, support the expansion of the domestic market, the generation of foreign currency and the import substitution industrialization. To do so, it sought to diversify its trade agenda, without ideological limitations, in Latin America, Eastern Asia and Eastern Europe; moreover, it impulsed the rapprochement with Argentina, within the perspective of rendering the main 


\section{Eduardo Brigidi de Mello}

core of the integration of the Latin American market (Dantas 1962). Here is the genesis of the "Third-Worldism" criticisms, which San Tiago Dantas contested by underscoring that the new emphasis occurred "without disdain of the possibilities of increase in trade with the United States and Western Europe" (Dantas 1962, 11).

In the sphere of cooperation, the IFP was the first to create a concrete integration benchmark with Argentina, through the 1961 Agreements of Uruguaiana; furthermore, it came closer to then-called "Third World", as seen within the discourse affinity with the NAM, into which Brazil entered as an observer. Other examples include the visit of Afonso Arinos to Senegal, the first of a Brazilian Chancellor to the African continent; the votes on anti-colonialist resolutions at the UN General Assembly (UNGA), where the strong discourse was translated into abstention when it concerned Portugal; the speeches against Cuba's suspension in the OAS; Vice-President João Goulart's visit to China. Another controversy of rhetorical proportion was caused by Jânio Quadros's decoration on Che Guevara, rather an eccentricity than a rupture indicative.

Pioneer in the extension of foreign policy limits, the IFP lacked density and bargaining power, using grandiloquent speeches as that of the " $3 \mathrm{D}$ " (Development, Disarmament, Decolonization) in the 1963 UNGA, or theses of little effectiveness, as that of the Collective Economic Security. Aware of its innovative character, it was limited to proposing a reformist approach, departing from the realistic conception that Brazil did not possess enough power resources. These could only be sought through the country's integration in the international relations, a position that would favor "defining the dependence terms together with the US", in "a continuity of the Operation Pan-America (OPA) that supplants JK's foreign policy parameters" (Visentini 2004, 133). To redefine the dependence alongside the US and to continue the OPA are a matter of renegotiating emphases, rather than essential ruptures per se.

\section{The Door to the Future}

"Development and social justice are of the same essence of the democratic ideals", said Arinos in the 1961 Message to the Congress (Arinos $2001,156)$. "The historical conciliation between the representative democratic 
system and a social reform capable of suppressing the oppression of the working class by the owning class", exhorted Dantas $(1962,5)$. Why were themes proper to the partisan politics in the voices of our Chancellors? Were those statements to co-opt the left or the emergence of a new emphasis? The answer could involve both explanations, a result of a more refined vision of the interaction between the internal and external spheres, in the face of the International Division of Labor (or Capital) consolidation in the postwar period. By speaking of social justice_or reform-as foreign policy's key variable, Jânio and Jango Administrations sought to give coherence to the discourse: to criticize the inequality between the states demanded criticizing it internally as well, claiming that both dimensions would be more legitimate if less unequal, in a symbiosis mediated by the foreign policy.

The emphasis would serve to defend "not only its own interests" (of Brazil), but also those "of the structurally weaker nations" (Dantas 1962, 34). Far from breaking away from tradition, however, the IFP was professedly subject to hemispheric restrictions. It was a doctrinal improvement, in a natural movement of complexity gain by the nation-state, without revision of principles or affiliation to other centers of power rather than those subject to the US hegemony. Its actions served as bargain movements to reinforce the essential position, without risking ruptures, being symptomatic the participation in the NAM as an observer only, in a pragmatic caution that balanced the speech.

The imbalance between practice and discourse was a natural consequence of the "independence" limits: the UN strengthening, the rationality, the non-alignment and the nascent south-south cooperation ran against the weight of bipolarity and the economic, commercial and financial dependence on the US. Even so, the IFP was the first arrangement that sought the national autonomy by means of universalism, a pinnacle of the process originated in the 1930 Revolution (Visentini 2004). To succeed, it required diversified geopolitical and geo-economic positioning, a project frustrated by the interruption of democracy. Thirty and eight years later, Lula's election would bring new impulse to the idea of equality as the external vector. 


\section{Eduardo Brigidi de Mello}

\section{The New IFP}

Discourse and/in action: globalist protagonism

Had they come back to life in 2003, Jânio and Jango would have had a double surprise. First, they would celebrate Brazil's evolution, as well as Lula Administration's turns to the IFP. Second, they would think that they were rereading newspapers from their time, given the criticism of the opposition and the press towards Lula Administration's foreign policy: "partisanship of the national interest"; "rupture with the diplomatic traditions"; "comrade diplomacy"; "Third-Worldism"; and, to top it all, "Bolivarianism" as the substitute for the specter of communism.

The New IFP, however, is a matter of emphasis. As New Republic's offspring, its source is the 1988 Constitution, whose article 4 defines the principles that crystallize the tradition initiated in 1930: national independence; prevalence of human rights; self-determination of the peoples; non-intervention; equality among the states; defense of peace; peaceful settlement of conflicts; repudiation of terrorism and racism; cooperation among peoples for the progress of humanity; and granting of political asylum. The sole paragraph of the same article determines that Brazil will seek the economic, political, social and cultural integration of the peoples of Latin America, aiming at the formation of a Latin American community of nations.

These are the principles that, in the constitutional framework, "govern our international relations". As public policy, the foreign policy must contribute as well to the achievement of the "fundamental objectives" listed in article 3 of the Constitution: to build a free, just and solidary society; to guarantee national development; to eradicate poverty and to reduce inequalities; and to promote the well-being of all. As starting points, in the Aristotelian conception, the principles are implemented by the mediation of the foreign policy and diplomacy, in constant dialectic at each emphasis and each choice. This is a multifaceted process, where the rugged path between practice and theory will show the fidelity of the action to the Constitution. The final point, the extreme of the path, is the realm of the emphasis, the foreign policy nuanced tool.

The emphases are mistaken, at times, for the principles that exacerbate, as in the cases of multilateralism and integration. The former are distinct from the latter, however, for being conjunctural adaptations of the democratically 
elect political project, since "different administrations give various degrees of importance for specific questions, subjects, regions and agendas" (Amorim 2010, 214). Among Lula Administration's emphases, the most remarkable was the protagonism, which gave effect to the globalism-or universalism-present for decades in the official discourse. Statistics reflect it as follows: between 2003 and 2010, Brazil received 904 visits from 137 countries or organizations; the President made 259 visits to 83 countries, while the Chancellor travelled 467 times to 101 countries (Amorim 2010).

The aforementioned process of universalization was concluded by the full adhesion to the international regimes in the 1990s (Cervo 2012a), which eliminated the isolationist burden from the Dictatorship. Although critics qualify this decade as a period of concessions without bargain (and then without counterpart compensations), the adhesion was positive by consolidating the base for the globalist protagonism of the New IFP, whose multilateral emphasis demanded the participation without barriers in the international organisms. While neoliberal policies had been domestically implemented since Collor Administration, with the gradual adoption of the Washington Consensus, they were externally limited to certain neutralism toward the system, by not giving emphasis to the criticism of the order inequalities, as occurred in the previous decades. As expected, such neutrality may have weakened, to some degree, strategic instruments related to the foreign policy. It was the case, for instance, of Vale do Rio Doce, whose privatization led to curious situations as the iron ore exportation to China, who sells it back to Brazil in the form of railroad tracks, with the due aggregate value.

It is not possible to affirm, however, that the 1990s conformist position irreversibly violated the tradition: Mercosur was deepened, though under a liberal tone; the margin of bargain and the possibility of commercial diversification were not threatened by unequal free trade agreements, as the FTAA, which would also make hamper the stimulus policies to the naval industry by means of governmental purchases (a typical example of the interaction between the foreign policy and the other public policies); the state control of Petrobras was kept, though under open capital; there was no adhesion to permanent political or military pacts (as OECD and NATO); and the signing of human rights or nuclear non-proliferation treaties, adhesion that 
constituted arguable emphasis, as mentioned, was not contrary to the constitutional principles.

Hence, the New IFP nuances were manifestations of the pretension to substitute the reactive position for an assertive one, that is, the desire to exert power aiming to positively influence the system by means of a "protagonism compatible" with the dimensions of the country (Amorim 2010; 2011, 273). Such protagonism, an emphasis of the globalist principle, was followed by the emphases of multilateralism and of south-south cooperation, supported by the value of equality. This very last stimulated the recovery of what Garcia (2013) calls "internal-external correlation", a separation that from 2003 on became "less clear" according to Amorim $(2011,26)$. If the development-guided by equality promotion-depends on the country's position in the system and must promote the democratic rules, the conceptualization of the dynamics between the internal and external dimensions is subordinated to the essence that distinguishes it, which is why the concept of democratic mirror is put forth, where the national democracy and the system's multilateralism mutually reflect.

Thus, the New IFP emphases-protagonism, democratic mirror, political and economic multilateralism, south-south cooperation and equality-crowned, externally, the state improvement process which had begun under the leadership of Getúlio Vargas. It has been a long path: the bureaucratic modernization and the siderurgy, initiated in the 1930s; the participation in the Second World War and the foundation of Vale do Rio Doce, in the 1940s; sovereignty over petroleum with the establishment of Petrobras and the creation of the Brazilian Development Bank (BNDES), in the 1950s; the concrete beginning of the integration with Argentina and the trade without ideological constraints, in the 1960s; the Nuclear Agreement with Germany, in the 1970s; the conception of Mercosur and the nuclear cooperation with Argentina, in the $1980 \mathrm{~s}$; the integration with the international regimes, in the 1990s; and, in 2000, the Brasilia Summit and the recovery of the South American integration which had begun with the proposal of the SAFTA in 1992. Gradually, actions and potentialities gave concretion to the discourse and allowed the emergence of the New IFP, naturally globalist and vocationally protagonist. 


\section{Lines and Objectives: Political Multilateralism}

"The democratization of international relations, without hegemonies of any kind whatsoever, is as important for the future of mankind as the consolidation and development of democracy within each state", claimed Lula in his inaugural speech, since "the denial of the plurality of poles, supposedly realistic, reduces the international relations to the expression of the military force only", he complemented in Paris (MRE 2007, 41). And, regarding the democratic mirror, he affirmed that "multilateralism represents for the international relations what democracy was and has been for the nations" (MRE 2007, 110).

As a relation of permanent coordination and negotiation between three or more states, on the basis of general principles of behavior and equality, multilateralism is characterized by indivisibility, universality and diffuse reciprocity. It is different from the unilateral logic (which is opposed) and from the bilateral one (of limited scope) because it relates to the general interest, in organizations-steady arenas for dialogue-that seek to solve structural problems of coexistence (Fonseca Jr. 2008). It is justified, therefore, as an emphasis of the New IFP, within which "not only the capacity to defend its own interest is weighed, but also the capacity to translate its own interest into a collective one" (Amorim 2011, 365).

It is a line and an objective at the same time, because the consolidation of multilateralism is a goal in itself. The New IFP sought not only major goals (to be a UNSC permanent member) but also the system improvement (to be member without veto power), having proposed justice arrangements based on the social choice theory (Sen 2009). Accordingly, pragmatism makes incremental gains possible as the core of the New IFP's multilateralism, which did not follow utopian theories as the Kantian peace or the universal government. The political multilateralism line, focused on international organizations, is sub-divided into various thematic areas, as security, human rights and the environment. In this sense the UN is a pivotal arena, where the efforts for the reform of the global governance as a whole converged, especially the G4-a group created by Brazil, Germany, India and Japan in 2004 with the intention to make the UNSC more "democratic, legitimate and representative (...) sensitive to a security approach that interweaves peace, development and social justice" (MRE 2007, 197-198). 


\section{Eduardo Brigidi de Mello}

There was an unequivocal leap of quality, a leap of emphasis: the UNGA opening statements began to have the concrete tool of the alliances of variable geometry, in order to balance-or to make less unbalanced-the international instances. Compared with the New IFP, which gave the principles political shrewdness and instrumental efficiency, including within the NorthSouth intermediation (Saraiva 2009), the previous statements had suffered from more abstraction and less geo-diplomatic support, generally limited to arguing theories, in an emphasis of discourse proper to formative periods. Within this context, the G4, for example, conquered legitimacy and contributed to the consensus on the obsolescence of the current rules (though not on the solutions); its constructive and gradualist proposals had the merit in improving the debate and keeping it in the agenda, which by itself reduces the probability or increases the costs of unilateral actions.

New IFP's political multilateralism urged to benefits reciprocity, which seeks to reverse the "Old Order" logic of asymmetries reproduction and leads, in the security realm, to replacing NATO's strategy of violence with that of the negotiated settlement of conflicts (Cervo 2012). Added to the G4, there were alliances of variable geometry with developing countries, which increased the capacity of attraction and articulation of Brazil in the international fora, especially Unasur, CELAC, IBSA and BRICS—new poles of the system. Concerning Mercosur, the New IFP's remark was to give it full integration character, endowing it with social, economic and political elements-as the establishment of the democratic clause in 2004. It was, thus, overcome the restricted vision on free trade, which does not observe-or even infringesarticle 4 of the Constitution, which determines that integration must occur in a broad sense.

Reactions were quick. By refusing the supporting role and adopting an activism correspondent to its weight of regional power and global actor, the country received paternal admonitions from developed countries, many of which were internalized ad litteram by the press or the opposition. This is what happened by betting on the BRICS or recognizing the State of Palestine, or by exacerbating multilateralism in the Iran-Brazil-Turkey Nuclear Agreement (Tehran Declaration), which generated one of the fastest UNSC reactions in history. Moreover, Brazil risked its image patrimony by accepting the 
MINUSTAH command (at which it keeps coordination with the US), with the proposal to incorporate the economic and social dimension into the peace processes, by means of active solidarity and non-indifference-which are $s u b$ emphases of the equality and the non-intervention emphases, respectively. The same occurred concerning Guinea-Bissau, by assuming the Presidency of the UN Peacebuilding Commission (from 2007 to date, being the only developing country in this condition), with great investment of diplomatic resources and over twenty projects of technical cooperation.

\section{Lines and Objectives: the Economic Multilateralism}

The New IFP evidenced and stimulated the relative redistribution of power in the macroeconomic coordination, trade and world finances, in order to revert the historic imposition of asymmetric rules by the developed countries. Combining Keynesian and neoliberal tools-a mix proper to pragmatism-the state questioned the Washington Consensus and resumed the strategic planning of the economy. The macroeconomic policies had the demonstration effect of opposing fundamentalist visions of the Market, which contributed to alter the logic of the structural adjustments and the state functions reduction. Underlying the value of reciprocity, one now also finds here the value of equality, which inverted the econometrics of standardizing prescriptions of the developed countries: the New IFP proposed that we "hold the ladder" (Chang 2004).

The commercial strategy debuted in 2003, in the Cancún Meeting of the WTO Doha Round, through the interaction between multilateralism and southsouth cooperation to balance the trade rules. Brazil led the formation of the G20 Agriculture Group, which gathers developing countries, causing remarkable shock: for the first time ever, a round would not be determined unilaterally by the developed countries, as underscored in the Group's Ministerial Communiqué (MRE 2007). As indicated in the 2008-2011 Strategic Orientation of Brazil's Ministry of External Relations (MRE), Doha should serve to "reach a more just and equitable international trade (...) so that its result benefits especially the developing and the poorer countries", barred from competing in equality of conditions (MRE 2007, 223-224).

Such claim did not derive from humanitarian reasons, rather from the assumption that trade openness requires the developed countries counterpart 


\section{Eduardo Brigidi de Mello}

compensation, particularly, the elimination of farm subsidies and non-tariff barriers. It was about, however, an intensification of the free-trade principle with protectionist nuances, for the country has contributed to the multilateral system since GATT's creation. With a diversified economy, Brazil would benefit from the multilateral agreements, unlike bilateral or regional strategies, within which the strongest countries combine cooptation and coercion over the weakest, in agreements that do not feature, for instance, mechanisms as the WTO dispute settlement system, which inhibits unilateral measures. The emphasis of equality, in turn, generated confidence to act as one of the leaders of the emergent countries along with India, facing the US and the European Union (Blustein 2010), a gain in substance that in the future would take one of its main negotiators to the position of Director-General of the entity, something unthinkable between 1961 and 2002.

One cannot blame Brazil for the Doha Round incompletion, which has been rather the result of the refusal of some countries to accept the reciprocity - except for themselves or small groups. It is a short-term vision that feeds major current conflicts and substitutes the WTO global agreement for the free trade agreements, perpetuators of asymmetric relations (Cervo 2012). Against these resources of force, the New IFP brandished the resources of the power of convergence, pragmatic and mutually respectful negotiation, which experience the perception of the new "diplomatic geography" that modified the "world economic geography", as Lula claimed (MRE 2007, 223). This is because, as defended toward Mercosur, the trade agreements should not deal with commerce growth only, ignoring productive integration and/or social development.

In parallel to the unprecedented protagonism at the Doha Round (Blustein 2010), Brazil initiated an incisive strategy of diversifying commercial partners, in a sort of extended reediting of the IFP. Examples include the exponential commerce increase in Mercosur, with South America, Africa, China, Arab countries and others, and the higher participation of manufactured goods in the trade with Latin America and the Caribbean, which started to buy $47 \%$ of the manufactures; the exports to South America, with 20\% of the agenda, doubled those to the US (Amorim 2011), which was also surpassed by Mercosur, both with higher participation of manufactured good. 
Those elements served to protect the country from capitalism's periodic instability, as seen in 2008, when the trade network, in addition to the domestic market and the state planning countercyclical policy, offered more defense alternatives compared to other countries, including developed ones. The difference of the state conception in relation to the neoliberal orthodoxy became evident by the role of the state banks, which provided against the private credit scarcity and contributed to mitigate the crisis. Moreover, despite the criticism of conservative ideological motivation, the interest in the increase of trade with the US and the European Union was kept, as expected within a globalist commercial strategy.

In this sense, and as a reply to the crisis, the Pittsburgh Declaration of the Financial G20, representative of $90 \%$ of the world GDP, highlighted in 2009 that the group became the main international forum on economic and financial debate, the first to congregate advanced and emerging countries. The same principle of reciprocity was applied then to economic themes, in which the developing countries started to influence in parameters previously defined almost exclusively by the central countries, which, as a matter of fact, had sponsored the excess freedom that led to the crisis (Cervo 2002a). It is here that the Brazilian discourse of defense of the commerce and the economic growth confronted protectionism, the expansive monetary policies and the prescription of the fiscal adjustment (Garcia 2013), as well as the market deregulation, which does not have as criterion the distribution of income or the reduction of inequality.

The importance of Brazil in this area should not be evaluated only by its low participation $(1 \%)$ in the international trade, but also by the size of its economy, among the world's ten largest for a long time, and the role it has in financial flows because of the interest that remunerates its internal debt. These potentialities stimulated the internationalization of the Brazilian companies and the loans of the Brazilian Development Bank (BNDES) for infrastructure works in South America. Moreover, they sped up the inversion of the relation with the World Bank and the IMF: the country not only paid off its debt but also made contributions, working along with other emerging countries to obtain the redistribution of quotas - the ten main members started to be six developed countries and the four original members of the BRIC. 


\section{Eduardo Brigidi de Mello}

\section{The South-South Cooperation}

"Prioritize the ties with the South of the world" is what Lula put forth when inaugurated. To the principlism—resistant, isolationist or conformist—of the previous decades was added the activism of the south-south cooperation, an emphasis that sought not to harm the relations with the developed countries, as constantly reminded by the President and the Chancellor. This approach would be justified inasmuch as the emerging countries are more inclined to reciprocity, the overcoming of asymmetries and the peaceful settlement of conflicts (Cervo $2012 a)$.

As an instrumental emphasis of the New IFP, the south-south cooperation also finds grounds in the constitutional principle of "cooperation among peoples for the progress of humanity". It is instrumental because, by congregating developing countries, it intensifies and strengthens the multilateral axes, as proven in the concerted actions of the BRICS and the Agricultural and Financial G20. This character was expressed by the Chancellor when he affirmed that the austral cooperation is "at the crossroads of all major guidelines", "helps to expand Brazil's participation in the international relations", "reinforces our stature and strengthens our position" and "is one way to engage in the reform of global governance" (Amorim 2010, 231, our emphases).

It confers substance, as well, to the globalist protagonism, mainly in the case of the BRICS, whose first official communiqué defended, not coincidentally, the strengthening of multilateralism and the primacy of the International Law, with UN's central role. Its instrumental functionality is confirmed by the opinion of Cervo (2012), who claims that the integration processes, "previously had as a sort of end in itself", started to be used "as means to establish or to consolidate the network of cooperation and power in the south". If it is worth underscoring, by the way, that multilateralism is not a characteristic essential to multipolarity, which can opt to form rival and/or noncooperative blocs.

One can also find here the differences between Lula administration and that of the $1990 \mathrm{~s}$, when resistance was substituted by acceptance of the international order and regimes, moving away from the developing countries discourse and the North-South dichotomy, in a strategy that did not have as 
emphasis the critique toward the system. The New IFP, in turn, resumed the moderate, pragmatic and propositional critique from previous periods, with alliances that generated new room for bargain and with an intense agenda that inserted social subjects in the globalization. Refractory toward ideological outbursts, it "contested without defying" the central countries and "respected without supporting" countries as Venezuela, Syria, Libya, Cuba and Iran (Visentini 2010, 68).

This instrumental line has South America as original base and had the expansion of the integration concept of Mercosur as nucleus, as to incorporate political (Parlasur, democratic clause), infrastructure (FOCEM - the structural convergence fund) and social themes components. It followed the goal of "a politically-stable, prosperous and united South America, founded upon ideals of democracy and social justice", as Lula said in his inaugural speech, making the continent Brazil's foreign policy's "greatest priority" (Amorim 2010, 227), the result of a "determined effort" that brought "more emphatically the concept of South America" (Amorim 2011, 318).

Perhaps the biggest success of the New IFP was Unasur's creation in 2008, an organization that "gave a face" to the continent (Amorim 2010, 230) and crystallized a permanent structure of political concert, including Councils of Defense, Health, Infrastructure and Fight against Drugs. Unasur was transformed into a permanent arena for dialogue and scenario projections, having acted with prominence in the 2008 Bolivian crisis; in the attrition of Colombia with Venezuela and Ecuador, also in 2008; in the joint dialogue with the US in the OAS Summits; and in the 2012 Paraguayan crisis. More than that, it was born with the objective of building a political and economic space unifying infrastructure and free trade, seeking to reduce asymmetries, with shared values and future, mutually protected regarding its natural resources: water, food production and energy sources, that is, elements that will give it room for autonomy and power.

The constitutional order of integration with the peoples of Latin America was followed in the creation of CELAC, whose original meeting was pointed out by MRE as the first of the countries of Latin America and the Caribbean without the participation of developed countries. They are concentric circles that start in a broader integrationist version, in Mercosur, passing by the hybrid Unasur, and arrive at the predominance of the political coordination, in 


\section{Eduardo Brigidi de Mello}

CELAC. The gradual protagonism concretion overflowed the regional limits as of the creation of IBSA, a group of great "affinity in politics and doctrine" (Amorim 2011, 461); in the rapprochement with Africa, which was once again "a real rather than rhetorical priority" (Amorim 2011, 33) and originated the Africa - South America Summit (ASA); in the rapprochement with the Arab countries, which generated the Summit of South American - Arab Countries (ASPA, in Portuguese); and in the capillarization of the Brazilian diplomatic network in an unprecedented scale.

This simultaneous process, of the globalist strategy concretion and protagonism essay, reached its height in the creation of the BRICS, a concert to counterbalance the domain of the central countries and strengthen multilateralism in its economic and political lines, promoting a new security strategy and economic rules that reduce inequalities. Concerning security policy, "the violence strategy started to be confronted, for the first time in a clear way, by a grouping of major countries about the international stage and internal, regional or global conflicts alike"; in the economic sphere, the BRICS started to exert pressure with its monetary reserves and sovereign wealth funds (over four trillion dollars in 2013), thus inhibiting the irradiation of the traditional guidelines that seek to limit the autonomy of national (and state) politics in the fiscal and financial areas (Cervo 2012).

The Lula administration put forth the correction of deficiencies-rather than the rupture of capitalist geopolitics-in order to contain the violent unilateralism of central countries, whose loss of relative power is seen in increasing symptoms of irrationality, destruction and death, which risk to destabilize the already precarious system of security and commerce, which would harm Brazil's aspiration for development. In many of these episodes the BRICS acted in a coordinated way, despite specific divergences. In the Brazilian case, the limits of the non-violent settlement proposed by the austral cooperation were observed in the case of the Tehran Declaration. With the initial endorsement of the US, the country engaged on one of the decade's main subjects, getting Iranian consent in such an unexpected way that triggered immediate reaction in the central countries as well as in the BRICS partners at the UNSC, besides Germany - a member of the political G4. In record time, the 
Council approved sanctions that annihilated the Nuclear Agreement, to which Brazil reacted cautiously.

Within economics, the reaction of the developed countries seems to prove itself in the change of commercial strategy by the US and the EU, which, facing the reciprocity demand made by the Agricultural G20, started to adopt regional strategies as the Transatlantic Partnership and the Trans-Pacific Partnership, as well as derived models as the Pacific Alliance. These models oppose the free trade spirit and intend to establish limited relations with central countries and some developing ones. It is emblematic that the Chancellor has identified parallel between the Tehran Declaration and the Cancún Meeting, as "pragmatic and constructive" initiatives that generated the aforementioned reactions (Amorim 2010).

Finally, the South-South cooperation-in a broad sense and focused mainly in the emerging countries-was complemented by the substantial increase in the technical cooperation offered to less-developed countries, demonstrating in a concrete way the Brazilian intention of a horizontal relation and without conditional ties. With the eventual imperfections of the practice, the Brazilian projects were taken especially to South America and Africa, besides Haiti. Within the former, Mercosur and later Unasur were the diplomatic "umbrellas"; within the latter, Brazil, individually or within the IBSA framework, carried out several model projects, which were also replicated in other regions of the world, from Mozambique to Mali, from Palestine to East Timor.

\section{Long-distance proximity: the timeline of the emphases}

Based on republican Constitutions and the value of equality, both the IFP and the New IFP represented key moments of the globalist inflection of the Brazilian foreign policy: the former carried out the essay of autonomy, while the latter adopted protagonism as the twenty-first century emphasis. Exempt from the Cold War limits, the New IFP repeated its counterpart by bringing the internal-external correlation to the foreground, making both of them the only doctrines implemented under center-left administrations—considering Jango's as the one in the IFP. Having preserved the principles, they meant continuity in the emphases' timeline: they "leaped" over dictatorship, in terms of democratic 


\section{Eduardo Brigidi de Mello}

legitimacy; and they "leaped" over the 1990-2002 period, regarding the conception of a strong state and the critique of the international order.

The comparison is also reinforced by the analysis of the official discourse. Chancellor Amorim recalls entering the diplomatic career, in 1963, under the bold and innovative foreign policy of San Tiago Dantas. Considering it a great symbol, he clarifies that New IFP's assertiveness would not be unprecedented because "even in previous occasions, Brazil has shown instances of autonomy, sought to open new spaces, especially in the period known as the independent foreign policy" (Amorim 2011, 313). Commenting on the rise in the profile of the relations with Africa compared to the previous administrations, he affirms that "the moment that features a qualitative leap, which combines this independent political attitude of Minister Azeredo da Silveira, or of the early 1960 s with the Africanist spirit under Gibson Barbosa-and which also empowers these two elements-was in the administration of President Lula" (Amorim 2011, 480, our emphasis), with the adoption of a "clearly independent attitude" (Amorim 2010, 217).

In the multilateral economic and political lines, the IFP and the New IFP resemble each other for their sub-emphases of multipolarity and diversification of alliances, mainly with the developing countries, which is a proximity instance certified by the criticisms of "Third-Worldism" that both received. The kinship is reinforced by the character of their differences, which are not of content, but rather of scale: IFP's shy rapprochement with the then peripheral countries, hindered by bipolarity, meets the New IFP in an age of south-south cooperation based on more solid political and economic elements, including now the domain of the strategic natural resources. If the IFP innovated by proposing commercial diversification (of both countries and of aggregate value), the New IFP materialized such goal, which extended its room for bargain toward the developed countries.

The gain in substance can be identified in the following comparisons: from NAM to BRICS; from the abstention in votes on colonialism to the recognition of the Palestinian State; from the Agreements of Uruguaiana to the scope expansion of Mercosur and the creation of Unasur and CELAC, in addition to the Summits of South America with Arab and African countries; from the cautious managements for the permanence of Cuba in the OAS to the 
decisive negotiations to revoke its exclusion in 2009, or the extension of the system limits with the Tehran Declaration. Moreover, the Agricultural G20, the participation in the Financial G20 and the new relation with the IMF contrast with the IFP, which proposed the creation of a "United Nations Fund for the development of the South", with exogenous and aid nature. Here is a symbolic note: the resolute formation of the BRICS contrasts with Jango's visit to China, in 1961, being notoriously one of the great controversies that preceded the 1964 Coup.

The justification for the approach of the Cuban question is another example of the IFP as a source of inspiration for the New IFP. The Chancellor confided that the arrangements to revoke OAS suspension of Cuba sought antecedents in the speeches of Dantas, which "until today are worth reading". Amorim mentions that he reread them on his way to the 2009 OAS Summit in San Pedro Sula, Honduras, then deciding for the claim on the grounds of the non-intervention and self-determination principles, because "they were the principles that San Tiago Dantas had invoked in 1962 to prevent the sanctions" (Amorim 2011, 234).

The comparison brings what we call paradox of the discourse. Being the start of the transition of emphases and aware of its limits, the IFP had freedom of discourse, though little room for practical actions. The New IFP, in turn, without the bipolar restrictions and with increasing responsibility in the maintenance of the order, had room and means to act, but it carried out a more balanced speech: Amorim theorized about the "solidary diplomacy" with prudence and pragmatism, while Dantas spoke of "oppression of the working class by the owning class" and Jânio decorated the communist guerrilla hero. The paradox and the historical moment limited the IFP to rhetorical and low density objectives, which were brought up to date by the concrete and bold actions of the New IFP.

Assuming democracy as the political regime, Jânio/Jango's and Lula's resort to popular support is also important. It is not a mere detail: under the democratic scrutiny, both the formulation and the execution of foreign policy are conditioned in a unlimited way in the internal (by voters, the press, lobbies) and external spheres (in accordance with the correlation of forces at a given moment), which is not the case in authoritarian regimes, where the circulation of ideas is restricted. Jango was confirmed in the Presidency by the 1963 
plebiscite and enjoyed an expressive approval rating, according to the poll carried out by Ibope on the eve of the Coup ${ }^{2}$, while Lula won two elections. Amorim declared that Lula made "the foreign policy that the people wants" and enjoyed $78 \%$ of approval according to the Pew Research Institute (Amorim 2008; 2010); Dantas, in an interview, assured that the IFP had the support of the "Brazilian people, who are showing their will, even to those would like to deprive them of it" (Dantas 1962, 146).

\section{Final note: equality and the democratic mirror}

"The same determination that goes into my endeavors and those of my partners to make Brazilian society more just and humane, I will invest in the establishment of international partnerships that foster equitable development and a more peace-loving, tolerant and solidary world", said Lula in his first statement before the UNGA (MRE 2007, 18-19). By emphasizing equality as premise, the New IFP ended up questioning the current version of the postmodernist culture, simultaneously massed and atomized; within which, the doctrines of hegemonic interest seek to minimize the value $v$. anti-value dichotomy and act without any ethical and political considerations (Bosi 2002).

The origin of human doing, however, remains axiological. The man or the politician who longs for changing the social fabric can only do so while powered by a value, which is a driving force at the end of the action-as its objective - and in its beginning — as motivation (Bosi 2002). Opposing the value, there are the anti-values, such as iniquity or the pure and barbarous realism, being themselves rivals of justice promotion and all of those that do not intend to create a utopian order, but rather inhibit or eliminate disparagingly unjust arrangements and acts. In this sense, Brazil's voice, imperfect yet influential, was added to the plurality of sources that enrich global democracy, which is a statement that unveils the symbiosis between the idea of justice and the democratic practices (Sen 2009).

For the New IFP, democracy is the fitting regime to promote justice in the internal and international dimensions, a correlation that, inspired by the

${ }^{2}$ Ver Reda 2003 e Martins 2013. 
value of equality, is reflected in the democratic mirror: national democracy and systemic multilateralism. Considering that pacifism was already integrated into tradition, the promotion of democratic justice as key variable is the emphasis of the Lula years, which materialized what had been glimpsed by the IFP. This was interrupted by the authoritarian violence that concentrated income, which temporarily suspended the process of sophistication of the Brazilian public policies - a path only rediscovered by the redemocratization.

By criticizing the concentration of wealth and power by a reduced group of countries, the New IFP restarted to point at injustice as the essential cause of systemic instabilities, since "social justice is an imperative for peace", said Lula (MRE 2007, 34). In this sense, developing countries, at times in conflict and at times pressured by asymmetries, echoed the Brazilian words, which is a prove of the power of dialogue in international politics. The apogee of this power of the New IFP was reached in the Tehran Declaration: repeated sanctions and threats of use of brute force were overcome by a pair of managements and a presidential visit, which was the fruit of the legitimacy of the new interlocutors.

As global protagonist and multilateral guarantor, the country abided by coherence when considering a UNSC reform where "the interest is not only to be part of the club, but to make the club something more democratic" (Amorim 2011, 464). It corroborated the importance of the substratum of values of its foreign policy by adopting solidarity, the sub-emphasis of equality, in "various bilateral actions stripped of immediate egoism", carried out in the humanitarian aid to 36 countries in 2010 alone and seen collectively favorable in the long term (Amorim 2011, 273).

Circumstances, contradictions and controversies influenced the actions of the period, which were subject, as any public policy, to contingencies and the special character of foreign policy-implemented out of the national jurisdiction. If criticism is always possible in relation to the nature of the object, hardly may the analysis ignore the results of the Lula administration in this area, according to the objectives that had been put forth. Deepening the globalist strategy, Brazil was a protagonist in the improvement of the world political and economic multilateralism, making use of south-south cooperation under the value of equality, which inspires the democratic mirror of the internalexternal correlation. Contributions of the New IFP, a matter of emphasis. 


\section{Eduardo Brigidi de Mello}

\section{REFERENCES}

Abbagnano, Nicola. 2000. Dicionário de Filosofia. São Paulo: Martins Fontes.

Amorim, Celso. 2006. "Lula faz política externa que povo quer". Entrevista ao sítio UOL. Accessed January 26, 2014: http://noticias.uol.com.br/ultnot/brasil/2006/10/13/ult1928u3050.jhtm

Amorim, Celso. 2010. "Brazilian Foreign Policy under President Lula (20032010): an overview". Revista Brasileira de Política Internacional 53 (número especial): 214-240. Brasília: Instituto Brasileiro de Relações Internacionais.

Amorim, Celso. 2011. Conversas com Jovens Diplomatas. São Paulo: Benvirá.

Arinos Filho, Afonso. 2001. Diplomacia Independente: um legado de Afonso Arinos. São Paulo: Paz e Terra.

Blustein, Paul. 2010. Desventuras das nações mais favorecidas. Brasília: FUNAG. Bosi, Alfredo. 2002. Literatura e Resistência. São Paulo: Companhia das Letras. Cervo, Amado Luiz. 2008. Inserção Internacional: formação dos conceitos brasileiros. São Paulo: Saraiva.

Cervo, Amado Luiz. 2012. "Apresentação: a Política Exterior do Brasil." Austral: Revista Brasileira de Estratégia e Relações Internacionais 1(2): 9-14.

Cervo, Amado Luiz. 2012a. "O Brasil na Atual Ordem Mundial." Austral: Revista Brasileira de Estratégia e Relações Internacionais 1(2): 37-59.

Chang, Ha-Joon. 2004. Chutando a escada: a estratégia do desenvolvimento em perspectiva histórica. São Paulo: UNESP.

Dantas, San Tiago. 1962. Política Externa Independente. Rio de Janeiro: Civilização Brasileira.

Garcia, Marco Aurélio. 2013. "Dez anos de Política Externa". In 10 anos de governos pós-neoliberais no Brasil: Lula e Dilma, organized by Emir Sader, 53-68. São Paulo: Boitempo; Rio de Janeiro: Flacso Brasil.

Martins, Rodrigo. 2013. "Verdade exumada", Carta Capital, 04 de novembro. Acessed January 29, 2014:

http://www.cartacapital.com.br/revista/773/verdade-exumada5637.html.

Mello, Eduardo Brigidi de. 2009. "A Nova Política Externa Independente." Master Dissertation in Political Science - Instituto de Filosofia e 
Ciências Humanas, Programa de Pós-Graduação em Ciência Política, Universidade Federal do Rio Grande do Sul, Porto Alegre. 130p.

MRE. 2007. Repertório de Política Externa: posições do Brasil. Brasília: Fundação Alexandre de Gusmão.

Quadros, Jânio. 1961. "Brasil's new Foreign Policy". Foreign Affairs 40(1). Accessed January 11, 2014: http://www.foreignaffairs.com/articles/23339/j\%C3\%83\%C2\%A2nioquadros/brazils-new-foreign-policy.

Reda, Paulo. 2003. "Jango tinha apoio popular ao ser deposto em 64, diz Ibope." Folha de São Paulo, March 09. Accessed January 29, 2014: http://www1.folha.uol.com.br/folha/brasil/ult96u46767.shtml

Saraiva, José Flávio Sombra. 2008. "Entre o permanente e o momentâneo." Folha de São Paulo, August 26. Accessed January 29, 2014: http://wwwl.folha.uol.com.br/fsp/opiniao/fz2008200809.htm.

Visentini, Paulo Fagundes. 2004. Relações Exteriores do Brasil (1945-1964): o nacionalismo e a política externa independente. Petrópolis: Vozes.

Visentini, Paulo Fagundes, e André Luiz Reis da Silva. 2010. "Brazil and the economic, political, and environmental multilateralism: the Lula years (2003-2010)." Revista Brasileira de Política Internacional 53 (número especial): 54-72. Brasília: Instituto Brasileiro de Relações Internacionais. 


\section{ABSTRACT}

The New Foreign Independent Foreign Policy (IFP) of the Lula Administration is compared to the IFP because of the emphases and the democratic legitimacy. It recovered the internal-external correlation and added protagonism to the globalist strategy through four axes: political and economic multilateralism, South-South Cooperation and equality. The first and the second, objectives; the cooperation, an instrument; the equality, the value that grounds them.

\section{KEYWORDS}

Brazilian Foreign Policy; Lula Administration; New Independent Foreign Policy. 



\section{NERINT}

The Brazilian Centre for Strategy and International Relations (NERINT) was the first center dedicated to the study and research in International Relations in Southern Brazil. It was established in August 1999 at the ILEA/UFRGS aiming the argumentative and innovative study of the main transformations within the post-Cold War international system. In parallel, NERINT has sought ways to contribute to the debate on a national project for Brazil through the understanding of the available strategic options to consolidate an autonomous international presence for the country, from the perspective of the developing world. Brazil"s choice of an "active, affirmative, and proactive diplomacy" at the beginning of the $21^{\text {st }}$ century has converged with projections and studies put forward over numerous seminars and publications organized by NERINT.

An outcome of its activity was the creation of an undergraduate degree on International Relations (2004), ranked the best in Brazil according to the Ministry of Education (2012), and a graduate level program, the International Strategic Studies Doctoral Program (2010). Two journals were also created: the bimonthly Conjuntura Austral and the biannual and bilingual Austral: Brazilian Journal of Strategy \& International Relations. Thus, besides ongoing research on developing countries, NERINT is also the birthplace of undergraduate and graduate programs, not to mention its intense editorial activities.

\section{PPGEEI}

The International Strategic Studies Doctoral Program (PPGEEI) started in 2010, offering Master and Doctorate degrees, both supported by qualified professors and researchers with international experience. It is the result of several developments on research and education at the Federal University of Rio Grande do Sul (UFRGS).

Its roots can be traced to the Brazilian Centre of Strategy and International Relations (NERINT), a centre established in 1999 which 
conducts research, seminars, and edits two journals. Other main partners are the Centre for Studies on Technology, Industry, and Labor (NETIT/FCE) and the Centre for International Government Studies (CEGOV), located at the Latin American Institute for Advanced Studies (ILEA/UFRGS). In 2004, an undergraduate degree in International Relations was created at the Faculty of Economics/UFRGS; in 2005 the Center for Studies on Brazil-South Africa (CESUL), recently renamed as Brazilian Centre for African Studies (CEBRAFRICA), was created. All those actions together enabled the rise of an independent line of thinking propped by specialized bibliography.

The research tradition that gave rise to PPGEEI was based on a prospective analysis of the trends of the 1990s. The remarkable expansion of Brazilian diplomacy and economics from the beginning of the century confirmed the perspective adopted, which allowed the intense cooperation with the diplomatic and international economic organizations in Brazil. The course is already a reference in the strategic analysis of the integration of emerging powers in international and South-South Relations.

The Program's vision emphasizes strategic, theoretical and applied methods, always relying on rigorous scientific and academic principles to do so. For this reason, it has been approached by students from all over Brazil and several other countries and it has established partnerships in all continents. Thus, the Graduate Program in International Strategic Studies is a program focused on understanding the rapid changes within the international system. Alongside NERINT, it publishes two journals: Conjuntura Austral (bimonthly) and Austral: Brazilian Journal of Strategy \& International Relations (biannual and bilingual).

PPGEEI has three research lines:

\section{- International Politics}

It emphasizes the analysis of the process of formation, implementation and evaluation of foreign policy. It seeks to confront patterns of international integration of strategic countries in South America, Africa and Asia, considering institutional patterns, trade policy, structures of intermediation of interest, governance, International Law and the role of actors of civil society in the South-South axis of contemporary International Relations. 


\section{Partners}

\section{- International Security}

It approaches the defense, strategy and security issues in the International System from a perspective that takes into account the most powerful states at the global level, but systematically introduces the question of the regional balances of power, the South-South axis, the existence of regional security complexes, military issues and the impact of information technology in the Digital Age.

\section{- International Political Economy}

It focuses on the international insertion of Brazilian economy and other major developing countries in South America, Asia and Africa; discusses the characteristics and effects of globalization; and develops comparative and sector studies concerned with the effects of the internationalization of companies and productive sectors. Special attention is paid to international financial crises and its effects in Brazil and other countries of the South.

\section{BRAZILIAN CENTRE FOR AFRICAN STUDIES (CEBRAFRICA)}

The Brazilian Centre for African Studies (CEBRAFRICA) has its origins in Brazil-South Africa Studies Centre (CESUL), a program established in 2005 through an association between the Federal University of Rio Grande do Sul (UFRGS) and Fundação Alexandre de Gusmão (FUNAG), of the Brazilian Ministry of Foreign Affairs. Its research activities are developed within the Brazilian Centre for Strategy and International Relations (NERINT), located in the Latin American Institute for Advanced Studies (ILEA) of UFRGS.

In March 2012, CESUL was expanded into CEBRAFRICA in order to cover the whole of Africa. At the same time, the South Africa series, which published five books, was transformed into the African Series, with new titles on the way. The centre's main objectives remain the same as before: to conduct research, to support the development of memoires, thesis and undergraduate memoires, to congregate research groups on Africa, to organize seminars, to promote student and professor exchanges with other institutions, to establish 
research networks and joint projects with African and Africanist institutions, to publish national and translated works on the field, and to expand the specialized library made available by FUNAG.

The numerous research themes seek to increased knowledge of the African continent and its relations to Brazil on the following topics: International Relations, Organizations and Integration, Security and Defense, Political Systems, History, Geography, Economic Development, Social Structures and their Transformations, and Schools of Thought. CEBRAFRICA counts among its partners renowned institutions from Brazil, Argentina, Cuba, Mexico, Canada, South Africa, Angola, Mozambique, Senegal, Cape Verde, Egypt, Nigeria, Morocco, Portugal, United Kingdom, Netherlands, Sweden, Russia, India, and China. Current researches focus on "Brazilian, Chinese, and Indian Presence in Africa", "Africa in South-South Cooperation", African Conflitcs", Integration and Development in Africa", "African Relations with Great Powers", and "Inter-African Relations). 


\section{SUBMISSION STANDARDS}

1.AUSTRAL: Brazilian Journal of Strategy \& International Relations publishes articles and book reviews:

2.The journal is divided in two sections: Articles (Artigos) and Book Review (Resenhas);

3.The research articles must contain a maximum of 70 thousand characters (including spaces and footnotes). Use only the standard format; the book reviews must contain a maximum of 4,5 thousand characters (spaces and footnotes included);

4.The footnotes should be strictly of a substantive and complementary nature;

5.The bibliography must follow the rules of the Chicago system (Author-date ou notebibliography), specifying the used literature at the end of the text;

6.Contributions must be original and unpublished and can be submitted in Portuguese, English or Spanish;

7. Contributions must contain the full name of the author, their titles, institutional affiliation

(the full name of the institution) and an email address for contact;

8.Publications of undergraduate students are accepted, as long as in partnership with an advisor professor, which will appear as the main author of the work;

9. Book reviews must contain the complete data and the ISBN of the analyzed work;

10. Contributions must be accompanied of: 3 keywords in Portuguese or Spanish and 3 keywords in English; Title in English and in Portuguese or Spanish; Abstract in English and in Portuguese or Spanish, both with up to 50 words.

11. Submissions must be made by the journal website: www.seer.ufrgs.br/Austral

\section{SUBMISSION PREPARATION CHECKLIST}

As part of the submission process, authors are required to check off their submission's compliance with all of the following items, and submissions may be returned to authors that do not adhere to these guidelines.

1. Contributions must be original, and shall not have been submitted for publication in another journal; otherwise, it must be justified in "Comments to the Editor".

2. Submitted files must be in Microsoft Word, OpenOffice or RTF (as long as their size is up to $2 \mathrm{MB}$ ) format.

3. URLs must be informed in the references when necessary.

4. The text must be single-spaced; Times New Roman typeface 12 pt must be used for the body of the text; italic is to be used instead of underline (except in URL addresses); Figures and Tables must be embedded in the text.

5. The text must follow patterns of style and bibliographical requirements described in Author Guidelines, in the section "About the Journal".

6. The identification of authorship of the work must be removed from the file and the Properties option in Word, thus ensuring the confidentiality criteria of the journal, if it is to be subjected to peer review (i.e. articles), accordingly with available instructions in the website. 


\section{PREVIOUS ISSUES}

\section{Available Online on: \\ www.seer.ufrgs.br/Austral}

\section{Volume 1, Number 1 (Jan/Jun. 2012)}

Presentation

Celso Amorim

Editor's Note

Paulo Visentini

The Future of MERCOSUR

Samuel Pinheiro Guimarães

The Brazil of Lula : A global and affirmative diplomacy (2003-2010)

Paulo Visentini

Russia turning on Latin America

Yuri Paniev

Reordering International Affairs: the Forum on China-Africa Cooperation

Mamoudou Gazibo, Olivier Mbabia

The Jacob Zuma Government's Foreign Policy: Association or Dissociation?

Chris Landsberg

South-South Cooperation and the Changing Role of the Gulf States

Kristian Coates Ulrichsen

The Financial Crisis and the Dollar Hegemony

Marcelo Milan 


\section{Volume 1, Number 2 (Jul/Dec. 2012)}

Editor's Note

Paulo Visentini

Presentation: The Foreign Policy of Brazil

Amado Luiz Cervo

The Lessons From The Euro Experience

Richard Griffiths

Brazil in the Current World Order

Amado Luiz Cervo

Neo-Developmentalism and the Search of a New International Insertion

Giorgio Romano Schutte

Teaching and Research on Foreign Policy in the Field of International Relations of Brazil Carlos Aurélio Pimenta de Faria

Brazil in Face of the Chinese Rise: the Risks of Regressive Specialization

André Moreira Cunha, Marcos Tadeu Caputi Lélis, Julimar da Silva Bichara, Manuela Gomes de Lima

The Impact of the International Crisis on Brazil's Trade with the Trade with the other BRICS (Russia, India, China and South Africa)

André Luiz Reis da Silva, Luiza Peruffo

Media and Foreign Policy in Lula's Brazil

Guilherme Stolle Paixão e Casarões

Developing From the South: South-South Cooperation in the Global Development Game Sean W. Burges

Colonial Globalisation to Post Colonial Globalisation: Non Alignment and South-South Cooperation

Aditya Mukherjee 


\section{Volume 2, Number 3 (Jan/Jun. 2013)}

Editor's Note

Paulo Fagundes Visentini

Military Power, Financial Crisis and International Security Panorama in The $21^{\text {st }}$ Century

Érico Esteves Duarte

Beyond The Organized Crime: The Reformulation of The Insurgency Concept and Its Impacts on The South America's Strategic Surroundings

Mariano César Bartolomé

South Africa, the South Atlantic and the IBSA-BRICS Equation: the Transatlantic Space in Transition

Francis Kornegay

Blue Amazon: Thinking the Defense of Brazilian Maritime Territory

Marianne L. Wiesebron

One Step Forward, Two Steps Back: Success and Failure in Recent Turkish Foreign Policy

\section{Ilter Turan}

The Arab Spring Incidents in the End of the "Green Era" in Libya: Questions on the Right to Intervention and the Duty to Interfere

Gladys Lechini, Norma S. Rabbia

South-South Cooperation: the Brazilian Partnership with Mozambique and the Construction of an AIDS Drug Plant

Maj-Lis Follér

The Value of the Concept of Hegemony for International Relations

Luiz Augusto Estrella Faria

Critically Thinking the Global Political Economy: Assessments for the Study of Middle Emerging Powers

\section{Leonardo Ramos}

The Implementation of Anti-Corruption Law in Business: Legal Control of Corruption Directed to Transnational Corporations

Luciano Vaz Ferreira, Fabio Costa Morosini 


\section{Previous Issues}

\section{Volume 2, Number 4 (Jul/Dec. 2013)}

Editor's Note: Brazil, the weakest link of BRICS?

Paulo Fagundes Visentini

Brazilian perspectives on the convergence between SISBIN and ZOPACAS Sérgio Gonçalves de Amorim

The South Atlantic, Southern Africa and South America: cooperation and development

Analúcia Danilevicz Pereira

The South Atlantic: Brazil-Africa Relations in the field of security and defense Sérgio Luiz Cruz Aguilar

The Central Bank of Brazil as an agent of International Relations

Mauro Salvo

Zero Hunger for the world - Brazil's global diffusion of its Zero Hunger

Strategy

Markus Fraundorfer

Triangular technical cooperation and the role of Inmetro

Leonardo Pace Alves

Inside the BRIC: analysis of the semiperipheral character of Brazil, Russia,

India and China

Daniel Efrén Morales Ruvalcaba

Latin American foreign policy and the Community of Latin American and

Caribbean States

Elsa Llenderrozas

Middle Powers in the frame of global climate architecture: the hybridization of the North-South gap

Leonardo Ramos

Geography and maritime potential of China and Iran

Sören Scholvin, Alexandr Burilkov 